\title{
Multiple C-H Activation Enabled Modular Construction of Densely Functionalized Sulfur-Contained Arenes
}

Received 00th January 20xx, Accepted 00th January 20xx

DOI: $10.1039 / x 0 x \times 00000 x$

\author{
Wensen Ouyang, Jianhang Rao, Jie Wang, Yang Gao, Yanping Huo, Qian Chen, Xianwei Li*a
}

Modular construction of multiple functionalized arenes from abundant feedstocks, stands as an unremitting pursue goal in synthetic chemistry, which would accelerate the discovery of new drugs an advanced materials. Herein, by using multiple C$\mathrm{H}$ activation strategy, through judicious choice of versatile imidate ester as the key directing group, expedi-ent delivery of molecular libraries of densely functionalized sulfur-contained arenes. Further synthetic application was demonstrated by multiple $\mathrm{C}-\mathrm{H}$ modification of fused arenes and pharmaceuticals such as Ibuprofen, and concise con-struction of biologically active molecules, Madam dihydrochloride and Bipenamol, was also achieved.

\section{Introduction}

The exploration of rapid construction of poly-functionalized molecules in concise manner, provided a new arena for advanced materials and drugs discovery. In this context, expedient delivery of densely substituted arenes, which serve as one most frequently occurred structural skeletons in chemical community, held great synthetic promise in various field. ${ }^{1}$ Towards this end, catalytic cascade reaction, such as Catellani-type reaction, using aryl halides or borons, has emerged as one reliable strategy for quick access to molecular complexiety. ${ }^{2}$

In pursuing for practicality of the overall process, multiple $\mathrm{C}-\mathrm{H}$ activation which features step-economy and would provide new retro-synthetic insight, would be highly desirable for the direct introduction of multiple functionality into molecules. However, formidable challenges ${ }^{3}$ (Scheme 1 ) remained in this field although C$\mathrm{H}$ activation has been witnessed great advancement in the past decades: 1) elusive control of site-selectivity, which often led to the formation of difunctionalization byproducts; 2) coordinative saturation, and thus, deactivation of metal catalyst, might be observed, which derived from the intrinsic directing group and the first introduced functionality; 3) moreover, steric and electronic influence, caused by the first $\mathrm{C}-\mathrm{H}$ functionalization intermediate.

To increase the synthetic utility of the overall process, the use of weak coordination directing groups, which are readily available and transformable groups, would be also beneficial for the second $\mathrm{C}-\mathrm{H}$ activation process. ${ }^{4}$ With the above principle in mind, herein, we developed a multiple $\mathrm{C}-\mathrm{H}$ activation strategy enabled polysubstituted arenes delivery, by using easily modifiable imidate ester as the key directing group. The synthetic application of this transformation was demonstrated by late-stage modification of materials and pharmaceuticals via multiple $\mathrm{C}-\mathrm{H}$ activation, and enabled concise construction of Bipenamol and key structural skeletons of biologically active molecules. Considering the synthetic versatile nitrile and thioether functionality, this transformation

\footnotetext{
a. School of Chemical Engineering and Light Industry, Guangdong University of Technology, Guangzhou, 510006, China.

Electronic Supplementary Information (ESI) available: [details of any supplementary information available should be included here]. See DOI: 10.1039/x0xx00000x
}

would serve as one arsenal for the modular construction of molecular libraries of multiple functionalized arenes.

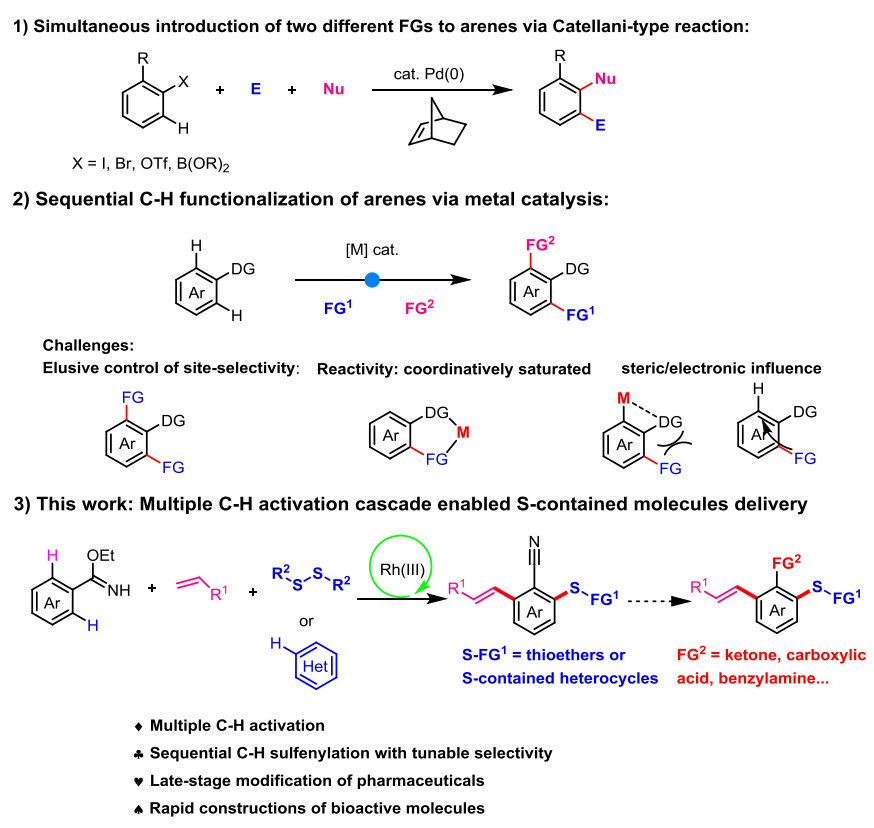

Scheme 1. Expedient delivery of poly-functionalized arenes.

\section{Results and discussion}

To commence our study for the concise construction of densely functionalized arenes via multiple $\mathrm{C}-\mathrm{H}$ activation, in our continuous research endeavor towards weak coordination enabled $\mathrm{C}-\mathrm{H}$ activation, ${ }^{5}$ readily available and modifiable imidate esters were selected, which has demonstrated to be traceless directing groups in $\mathrm{C}-\mathrm{H}$ activation. This multiple $\mathrm{C}-\mathrm{H}$ activation cascade was inspired by our initial finding that switchable selectivity in $\mathrm{C}-\mathrm{H}$ sulfenylation ${ }^{6}$ was observed that nitrile substituted aryl thioether 8a was obtained when using $\mathrm{Cu}$ (II) salt as the additive under $\mathrm{Rh}$ (III) catalysis, ${ }^{7}$ while thioether product 9 a was obtained as the major product with imidate ester remained intact (Scheme 2). Notably, when conducting this 
multicomponent reaction by successive addition of imidate $\mathbf{1}$ disulfide $\mathbf{3}$ and styrene $\mathbf{2}$, led to no desired multiple $\mathrm{C}-\mathrm{H}$ activation product $4,{ }^{8}$ while only $\mathrm{C}-\mathrm{H}$ sulfenylation product $8 \mathrm{n}$ was obtained as the major product. It was speculated that this transformation might proceed via $\mathrm{C}-\mathrm{H}$ activation of aryl imidate esters, affording to the 5membered rhodacycle $\mathbf{A}$, which assisted the generation of $\mathrm{C}-\mathrm{H}$ sulfenylated product $\mathbf{9 b}$ by addition of electrophilic disulfide $\mathbf{3}$. Further interaction of thioether and intrinsic imidate imidate group led to the over-coordination of the rhodium catalyst, and thus, no catalytic reactivity of $\mathrm{Rh}$ (III) species B was exhibited when further addition of styrene $\mathbf{2}$ into the standard conditions. Finally, ortho thioether substituted aryl nitrile product $\mathbf{8 n}$ was obtained, with the treatment of base to the intermediate $\mathbf{9 b}$ or $\mathbf{B}$.

1) Our initial finding: switchable selectivity in $\mathrm{C}-\mathrm{H}$ sulfenylation

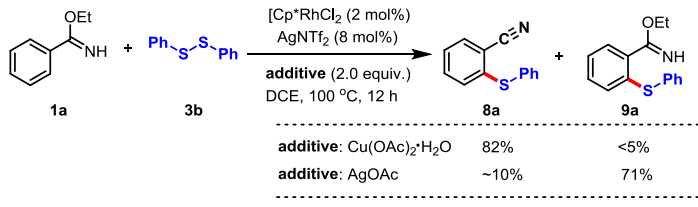

2) This work: poly-functionalized arenes delivery via multiple $\mathrm{C}-\mathrm{H}$ activation

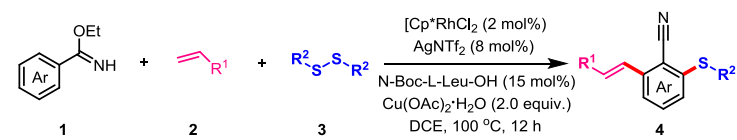

3) Successive addition of imidate 1, disufide 3 and styrene 2 led to no desired product 4:

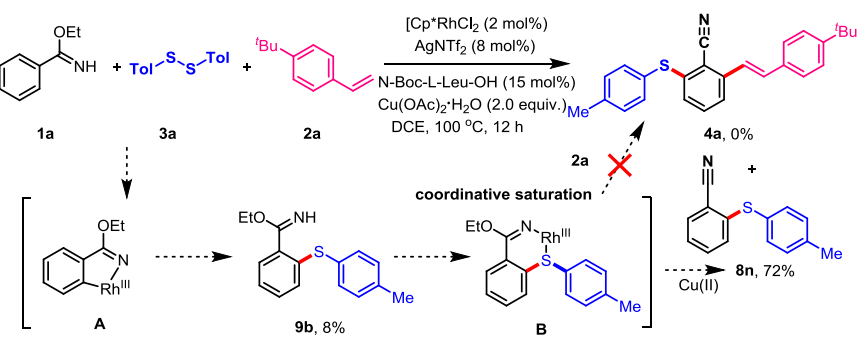

Scheme 2. Imidate esters enabled multiple $\mathrm{C}-\mathrm{H}$ activation.

The above observations encourage us to investigate this multiple $\mathrm{C}-\mathrm{H}$ activation cascade in details, as summarized in Table 1, $\mathrm{Rh}$ (III) exhibited optimal result for the poly-functionalized arenes $\mathbf{4}$ delivery, with the assistance of $\mathrm{Cu}(\mathrm{II})$ salt. Further investigation of reaction conditions indicated that $\mathrm{Ru}(\mathrm{II})$ could also serve as the catalyst, albeit in moderated yield (entry 2), while $\mathrm{Ir}(\mathrm{III}), \mathrm{Pd}(\mathrm{II})$ and $\mathrm{Ni}$ (II) complexes showed no catalytic activity for this multiple $\mathrm{C}-\mathrm{H}$ activation (entries 3-5). Control experiments indicated that Rh(III) catalyst, AgNTf played pivotal roles in this multiple $\mathrm{C}-\mathrm{H}$ activation cascade, and only trace amount of poly-substituted arene product 4a was obtained without them (entries 6-7). Dramatic decreased efficiency was observed in the sequential $\mathrm{C}-\mathrm{H}$ activation, when N-Boc-L-Leu-OH was replaced by $\mathrm{HOAc}$ or $\mathrm{PivOH}$ (entries 8-9). $\mathrm{Cu}(\mathrm{II})$ salt was also crucial for this transformation, since no desired product 4a was isolated in the absence of it, and only trace amount of $4 a$ was isolated when using molecular oxygen as the terminal oxidant (entries 10-11). Intriguingly, when direct use of phenthiol instead of disulfide $3 a$ in this transformation (entry 12), the desired product could also be obtained. Lower the reaction temperature was detrimental for the formation of the multiple functionalized arene product $4 a$. When using acetone or ${ }^{t} \mathrm{BuOH}$ as the solvent instead of DCE, only trace amount of product 4 a was obtained (entry 14). Notably, other common directing groups such as ketone (1a-1), ester (1a-2), amide (1a-3), N-NO (1a-4) exhibited no catalytic efficiency in this multiple $\mathrm{C}-\mathrm{H}$ activation reaction.

Table 1. Exploration of reaction conditions for the synthesis of polyfunctionalized arenes via multiple $\mathrm{C}-\mathrm{H}$ activation. ${ }^{a}$

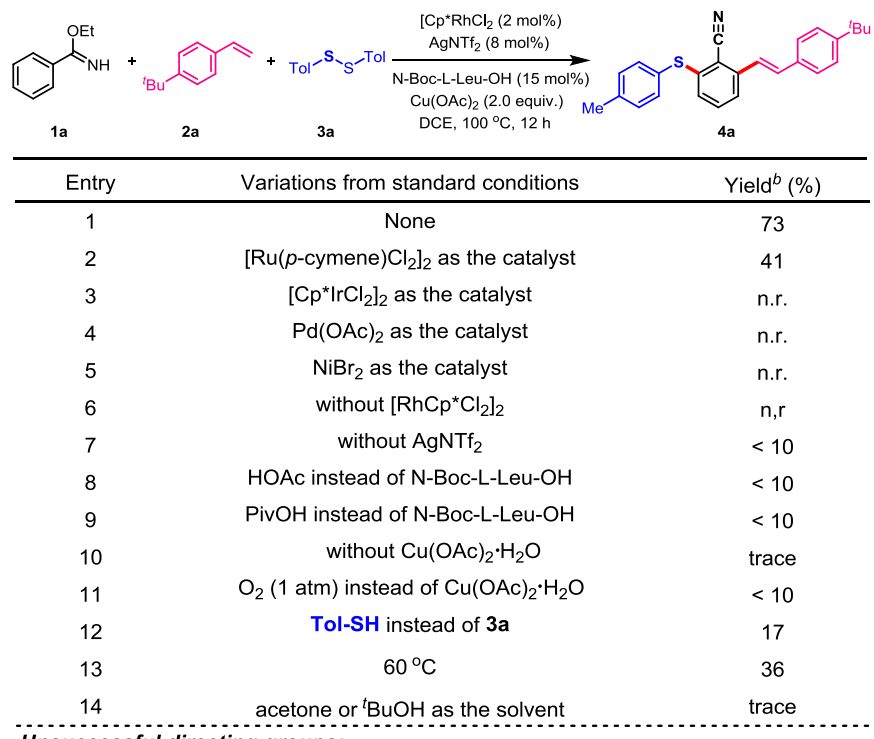

\section{Unsuccessful directing groups:}
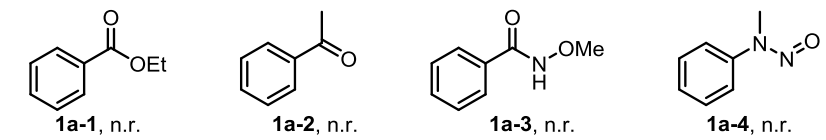

a Standard conditions: 1a $(0.10 \mathrm{mmol}), 2 \mathrm{a}(0.15 \mathrm{mmol}), 3 a(0.15 \mathrm{mmol})$, $\left[\mathrm{RhCp}^{*} \mathrm{Cl}_{2}\right]_{2}$ (2 mol\%), AgNTf 2 (8 mol\%), N-Boc-L-Leu-OH (15 mol\%), Cu(OAc) $\cdot \mathrm{H}_{2} \mathrm{O}$ (2.0 equiv.), DCE $(1 \mathrm{~mL}), 100{ }^{\circ} \mathrm{C}, 12 \mathrm{~h} .{ }^{b}$ Isolated yield. n.r. = no reaction.

With the optimal condition in hand, we further explored the substrate scope in this multiple $\mathrm{C}-\mathrm{H}$ activation for the production of poly-functionalized arenes 4 (Scheme 3). Intriguingly, further exploration of this sequential $\mathrm{C}-\mathrm{H}$ activation revealed that when using $\mathrm{Ag}(\mathrm{I})$ instead of $\mathrm{Cu}(\mathrm{II})$ salt in multiple $\mathrm{C}-\mathrm{H}$ activation, polyfunctionalized arene product $\mathbf{5}$ were obtained, with imidate ester functionality remained intact. Further assessment of substrates indicated that an array of aryl imidate esters, including methyl (4e, 5f), methoxyl (4f), fluoro (4c) and chloro (5c) substituents, could be compatible. For disulfides coupling partners, substituted aryl disulfides $(\mathbf{4 a}, \mathbf{4 b})$ including poly-substituted $(\mathbf{5 b})$, and even steric hindered disulfides (5a) could well participate in this sequential $\mathrm{C}-\mathrm{H}$ activation. Olefins $(\mathbf{4 a}, \mathbf{4 d})$ including halides substituted styrenes $(\mathbf{5 d}$, 5e) could serve as suitable substrates, which provide opportunity for further decoration of the obtained densely functionalized products via cross-couplings. 


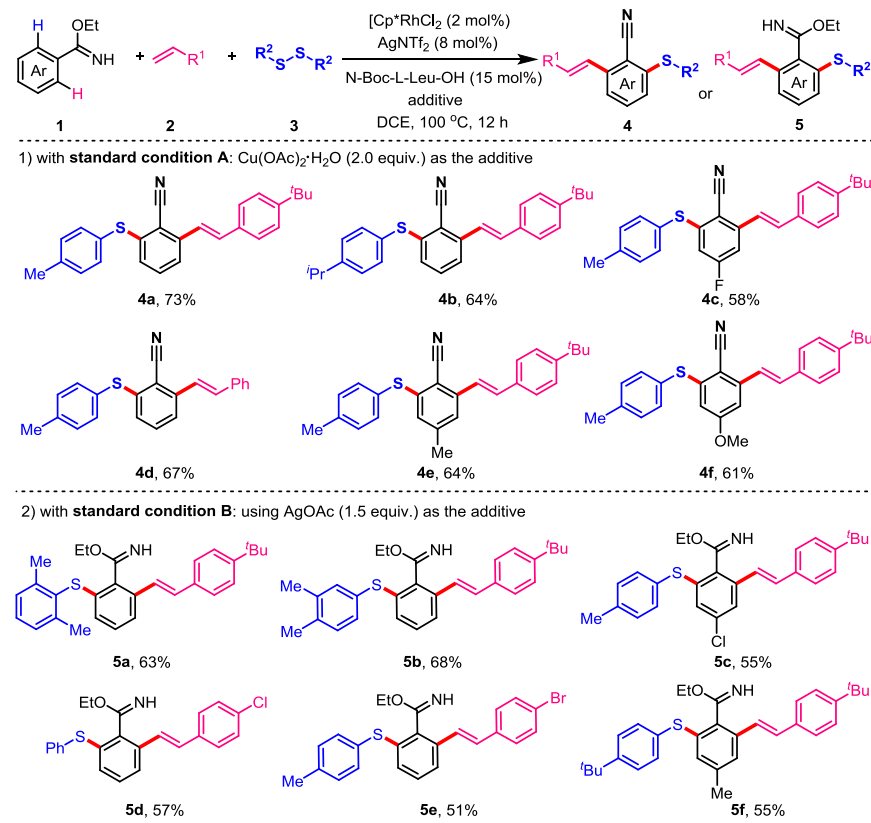

Scheme 3. Concise delivery of poly-functionalized arenes via multiple $\mathrm{C}-\mathrm{H}$ activation cascade.

Significantly, sequential $\mathrm{C} 3-\mathrm{H}$ olefination and $\mathrm{C} 1-\mathrm{H}$ sulfenylation of naphthalene derivatives was achieved, affording to 1,2,3-multiple functionalized naphthalene $\mathbf{5 g}$ (Scheme $4-1$ ), which was synthetically valuable skeleton while might be difficult to access by other procedures. Further synthetic application of this sequential $\mathrm{C}-\mathrm{H}$ activation was demonstrated by multiple modification of pharmaceutical, Ibuprofen derivative (4g) (Scheme 4-2).

1) Sequential $\mathrm{C} 3-\mathrm{H}$ and $\mathrm{C} 1-\mathrm{H}$ activation of naphthalene:

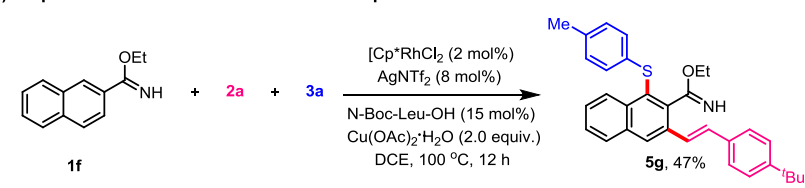

2) Multiple C-H activation for the late-stage modification of pharmaceuticals:

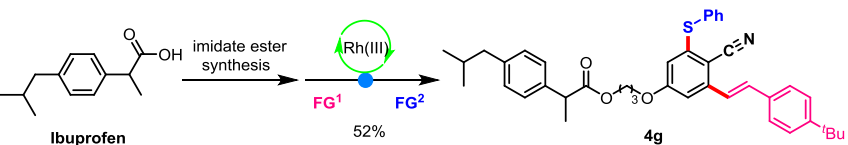

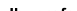

3) Multiple C-H activation via dual cross-dehydrogenative coupling strategy:

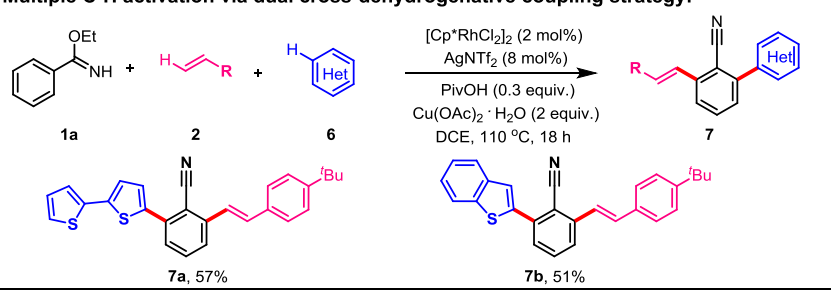

Scheme 4. Synthetic transformations.

Inspired by above results, we are delighted to find that sequential introduction of $\mathrm{C}-\mathrm{C}$ double bond and heterocycles could be achieved via multiple cross-dehydrogenative coupling (CDC) strategy (Scheme 4-3). ${ }^{9}$ With the assistance of PivOH under Rh(III) catalysis, two $\mathrm{C}-\mathrm{C}$ bonds were constructed through sequential aryl $\mathrm{C}-\mathrm{H} /$ alkenyl $\mathrm{C}-\mathrm{H}$ bond and aryl $\mathrm{C}-\mathrm{H} /$ heteroaryl $\mathrm{C}-\mathrm{H}$ bond activation, affording to multiple functionalized arenes. Thiophenes (7a), benzothiophenes (7b) could act as suitable electron-rich heterocycles, and participate in this multiple cross-dehydrogenative coupling smoothly. Notably, biaryl nitriles were widely used liquid crystal materials, and considering the readily transformable functionality contained in the products, this methodology could provide an expedient procedure for rapid construction of molecular libraries of multiple functionalized arenes, which might find synthetic value in pharmaceuticals, agrochemicals and material science.

Multiple functionalized sulfur-contained molecules ${ }^{10}$ serve as key skeletons occurred in pharmaceuticals, pesticides and advanced materials (Scheme 5), which have stimulated continuous research endeavor towards their concise delivery. Of note, Ullmann-type reaction that utilized aryl halides with sulfenylation reagents under metal, photo- and electronic catalysis, has been demonstrated to be a reliable tactics. Direct $\mathrm{C}-\mathrm{H}$ sulfenylation has emerged as one promising strategy for the selective introduction of S-contained functionality, nevertheless, the use of readily available and transformable directing group would facilitate rapid construction of functionalized sulfur molecular libraries.

Herein, divergent $\mathrm{C}-\mathrm{H}$ sulfenylation with tunable selectivity was achieved, assisted by versatile imidate esters, which enabled modular construction of S-containing molecular libraries. Great functional group compatibility of this transformation enabled latestage modification of bioactive molecules and advanced materials, significantly, expedient construction of pharmaceuticals, such as bipenamol and key skeleton of madam, were also achieved.

1) Switchable selectivity in C-H sulfenylation using transformable DG:

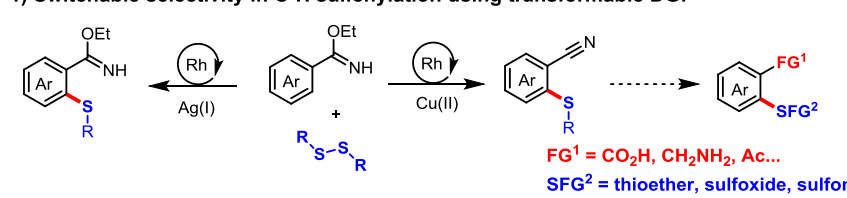

2) Functionalized aryl sulfur compounds in pharmaceuticals and organic electronics:

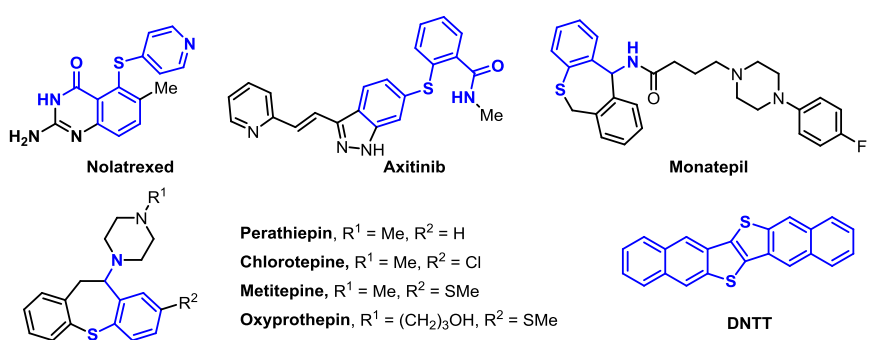

Scheme 5. Concise construction of sulfur contained molecular libraries via $\mathrm{C}-\mathrm{H}$ activation.

With the optimal condition for this tunable $\mathrm{C}-\mathrm{H}$ sulfenylation with readily transformable imitates, ${ }^{11}$ we first explored the synthetic generality for the production of 1,2-thiobenzonitriles, ${ }^{12}$ and great functional group tolerance was exhibited (Scheme 6). Widely used functionality in pharmaceuticals and materials, such as fluoro (8b) and trifluoromethyl (8f), could be well tolerated. Halides including chloro (8c), bromo (8d), and even iodo (8e), were compatible, holding great synthetic potential for further decoration of thioether products via cross-coupling reactions. Substrates bearing readily transformable groups, eg., nitro $(\mathbf{8 g})$, benzyl chloride (8i), and widely used as directing group, methoxyl (8h), could participate in this tunable $\mathrm{C}-\mathrm{H}$ sulfenylation smoothly. Heterocycles and fused ring system could be well serve as suitable substrates in this regioselective $\mathrm{C}-\mathrm{H}$ sulfenylation, notably, directing effect outcome the intrinsic electronic effect. For instance, $\mathrm{C} 3-\mathrm{H}$ sulfenylation of 
thiophene (8j), without the observation of $\mathrm{C} 2-\mathrm{H}$ activation product; $\mathrm{C} 3-\mathrm{H}$ sulfenylation of naphthalene $(\mathbf{8 k})$, and $\mathrm{C} 6-\mathrm{H}$ sulfenylation of indole (8I) took place with great regioselectivity.

For disulfides partners, both aromatic and aliphatic disulfides were suitable substrates in this regioselective $\mathrm{C}-\mathrm{H}$ sulfenylation. Ester $(8 \mathrm{~m})$, methoxyl $(\mathbf{8 0})$, fluoro $(\mathbf{8 p})$, chloro $(\mathbf{8 r})$, bromo $(\mathbf{8 q})$ were well tolerated, affording to the desired 1,2-thiobenzonitriles in good yield. Notably, no obvious steric effect was observed as for disulfides, ortho-substituted and even 2,6-disubstituted disulfides could serve as suitable sulfenylation reagents $(\mathbf{8 r}, \mathbf{8 s}, \mathbf{8 t})$. Heterocycles and fused arenes such as thiophene $(\mathbf{8 u})$, naphthalene $(\mathbf{8 v})$ substituted disulfides, could be well tolerated. Aliphatic such as benzyl $(\mathbf{8 w})$ and pentyl (8x) disulfides also served as suitable sulfenylation reagents.

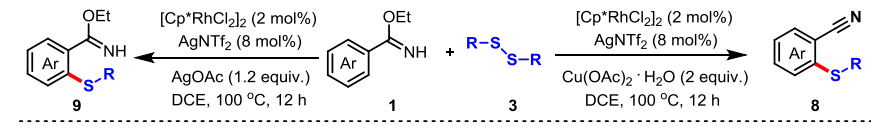

i) Ortho-sulfenylated aryl nitriles synthesis:

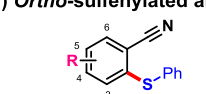

$8 b, R=4-F, 80 \% ; 8 c, R=4-C l, 84 \%$; $8 d, R=4-B r, 85 \% ; 8 e, R=4-1,73 \%$; 8f, $\mathrm{R}=4-\mathrm{CF}_{3}, 76 \% ; \mathbf{8 g}, \mathrm{R}=4-\mathrm{NO}_{2}, 81 \%$ Bh, $\mathrm{R}=5$-OMe, $87 \% ; 8$ i, $\mathrm{R}=\mathrm{CH}_{2} \mathrm{Cl}, 89 \%$

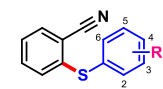

$8 m, R=2-\mathrm{CO}_{2} \mathrm{Me}, 75 \% ; 8 n, R=4-\mathrm{Me}, 72 \%$

$80, R=4-O M e, 83 \% ; 8 p, R=4-F, 81 \%$ $80, R=4-O M e, 83 \% ; 8 p, R=4-F, 81 \%$
$8 q, R=4-B r, 78 \% ; 8 r, R=2-C l, 72 \%$

$8 \mathbf{s}, \mathrm{R}=2,6-d-\mathrm{d}-\mathrm{Me}, 57 \% ; 8 \mathrm{8t}, \mathrm{R}=2-\mathrm{Br}, 62 \%$

ii) Ortho-sulfenylated imidate esters synthesis:

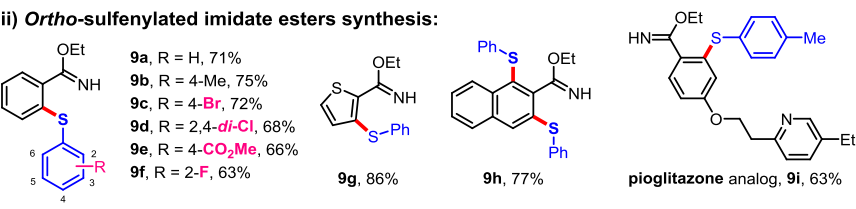

iii) Competing coordination in multiple substituted ar......

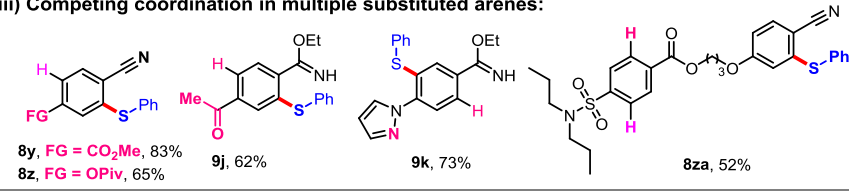

Scheme 6. Tunable $\mathrm{C}-\mathrm{H}$ sulfenylation enabled by imidates.

Intriguingly, the use of $\mathrm{Ag}(\mathrm{I})$ salt under $\mathrm{Rh}$ (III) catalysis switched the chemoselectivity to that of $\mathrm{Cu}(\mathrm{II})$ salt, and led to formation of thioether products 9 . Functional groups including fluoro (9f), chloro (9d), bromo (9c), ester (9e) were well compatible. Heteroaryl and naphthalene substituted imidate esters $(9 \mathrm{~g}, 9 \mathrm{~h})$ could also afford the desired products with good efficiency. This transformation could also enable late-stage modification of biologically active molecules, eg., plotlitazone analogue (9i).

The exploration of catalytic systems that could distinguish one specific $\mathrm{C}-\mathrm{H}$ bond in complex molecules remained a formidable challenge, ${ }^{13}$ we thus further investigated the competing coordination of multiple functionalized arenes, and imidate ester showed directing priority to ester (8y), ketone (9j) and phenol ester $(\mathbf{8 z})$, while $\mathrm{N}$-heterocycle pyrazole overrides imidate ester (9k). Notably, site-selective $\mathrm{C}-\mathrm{H}$ sulfenylation of probenecid analogue took place exclusively (8za), with $\mathrm{C}-\mathrm{H}$ bonds proximal to sulfonamide and ester remained intact. This site-specific $\mathrm{C}-\mathrm{H}$ functionalization of multiple functionalized arenes would provide valuable synthetic insight into late-stage modification of complex pharmaceuticals.

Further synthetic application by late-stage modification of materials and pharmaceuticals (Scheme 7) indicated that orthoselective $\mathrm{C}-\mathrm{H}$ sulfenylation of $4^{\prime}$-(hexyloxy)-[1,1'-biphenyl]-4carbonitrile proceed smoothly (10a), which was one important liquid crystal molecule. Pharmaceuticals such as ibuprofen (10b), and natural product L-Menthol $(\mathbf{1 0 c})$ could be readily modified via regioselective $\mathrm{C}-\mathrm{H}$ sulfenylation, while estrone $(\mathbf{1 0 d})$ could be well decorated with nitrile and thioether functionality. Considering the widely utility of nitriles and thioethers in biologically active molecules, this transformation might provide valuable insight into the advanced materials and new drug discovery.
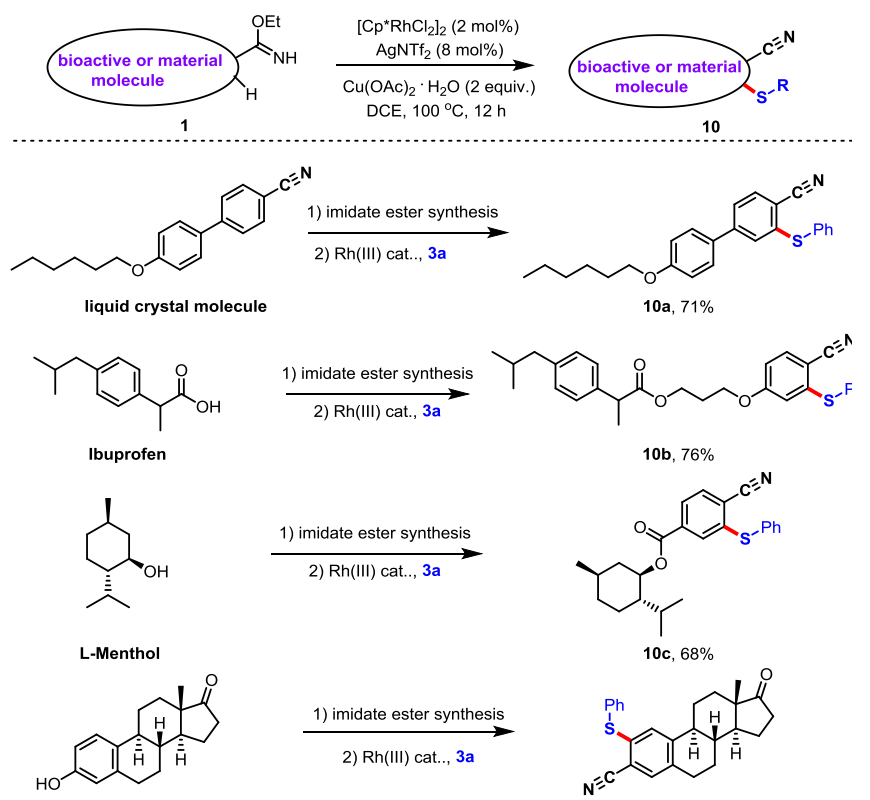

Scheme 7. Late-stage modification of material molecules and pharmaceuticals.

The readily transformable nitrile and thioether groups in the obtained products could serve as a versatile platform for the rapid construction of functionalized sulfur molecular libraries (Scheme 8). Benzo[b]thiophene skeleton could be readily introduced via crosscoupling of halides to give 11, oxidation of thioether afforded to diaryl sulfone 12. The versatile aryl nitrile group underwent hydrolysis to afford carboxylic acid $\mathbf{1 3}$, and could be easily reduced to benzyl amine $\mathbf{1 4}$ (Scheme 8-1). Sequential C-H activation served as a reliable arena for the expedient delivery of functionalized molecules in a selective manner, in this context, functionalized dibenzo[ $[b, d]$ thiophene $\mathbf{1 5}$ could be accessed via a sequential imidate enabled ortho $\mathrm{C}-\mathrm{H}$ sulfenylation followed by intramolecular $\mathrm{C}-\mathrm{H}$ arylation (Scheme 8-2). Further synthetic utility was demonstrated by concise delivery of Madam dihydrochloride analogue 16 via ortho $\mathrm{C}-\mathrm{H}$ sulfenylation with primary amine substituted disulfide (Scheme 8-3). Significantly, Bipenamol, an antidepressant, could be concisely accessed from commercial available thiosalicylic acid via ortho $\mathrm{C}-\mathrm{H}$ sulfenylation of aryl imidate ester, followed by selective reduction with $\mathrm{LiAlH}_{4}$, with a total $72 \%$ yield in two steps (Scheme 8-4). 
1) Further transformations of the obtained 1,2-thiobenzonitrile products:

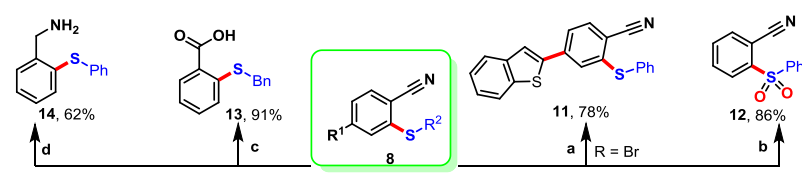

2) Sequential C-H sulfenylation and C-H arylation:
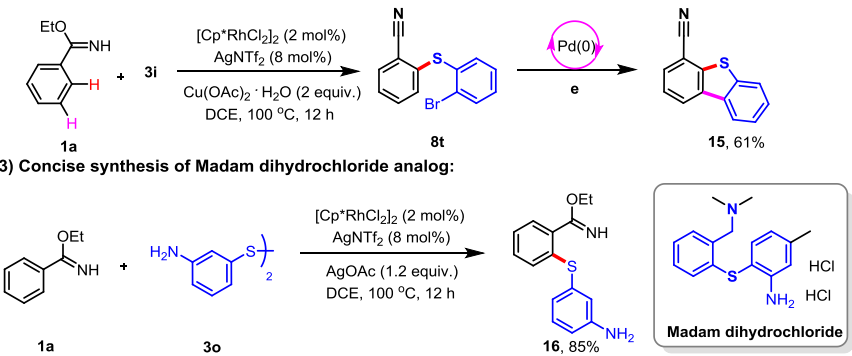
4) Expedient delivery of Bipenamol:

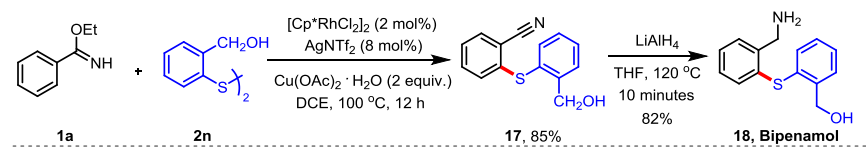

Conditions: a) 8d (0.1 mmol), $\mathrm{Pd}\left(\mathrm{PPh}_{3}\right)_{4}$ (5 mol\%), 1,4-dioxane (0.1 M), $\mathrm{NaHCO}_{3}$ aqueous solution, benzo[b]thiophen-2-ylboronic acid (1.1 equiv.), $\mathrm{rt}$ to reflux, $1 \mathrm{~h}$; b) $8 \mathrm{a}(0.1 \mathrm{mmol}), m$ CPBA (1.5 equiv.), EtOAc $(0.2 \mathrm{M}), 0{ }^{\circ} \mathrm{C}, 12 \mathrm{~h}$; c) $8 \mathrm{w}(0.1 \mathrm{mmol}), 1.5 \mathrm{M} \mathrm{NaOH}$ (aq., 30 equiv.), ethylene glycol $(0.04 \mathrm{M})$, $130{ }^{\circ} \mathrm{C}$, overnight; $2 \mathrm{M} \mathrm{HCl}$ (40 equiv.); d) 8 a (0.1 mmol), $\mathrm{LiAlH}_{4}$ (4 equiv.), $\mathrm{Et}_{2} \mathrm{O}$ (0.2 M), $0{ }^{\circ} \mathrm{C}, 1 \mathrm{~h} ; 4 \mathrm{M} \mathrm{NaOH}$ (aq.); e) 8t (0.3 mmol), $\mathrm{PdCl}_{2}\left(\mathrm{PPh}_{3}\right)_{2}(2 \mathrm{~mol} \%)$, KOPiv (2.0 equiv.), DMA, $140{ }^{\circ} \mathrm{C}, 12 \mathrm{~h}$.

Scheme 8. Synthetic applications.

To shed some mechanistic insight into this transformation, some control experiments were performed (Scheme 9). Experimental observations indicated that the use of 2 equivalent of $\mathrm{Cu}$ (II) salt assisted the conversion of $9 \mathbf{a}$ to $\mathbf{8 a}$, which might due to the more Lewis acidity of $\mathrm{Ag}(\mathrm{I})$ to that of $\mathrm{Cu}(\mathrm{II})$ (Scheme 9-1). Radical trapping experiments that with the addition of stoichiometric TEMPO or 1,4dinitrobenzene led to no obvious effect of the transformation between $\mathbf{1} \mathbf{a}$ and $\mathbf{3 a}$ to afford $\mathbf{8} \mathbf{a}$ (Scheme 9-2).

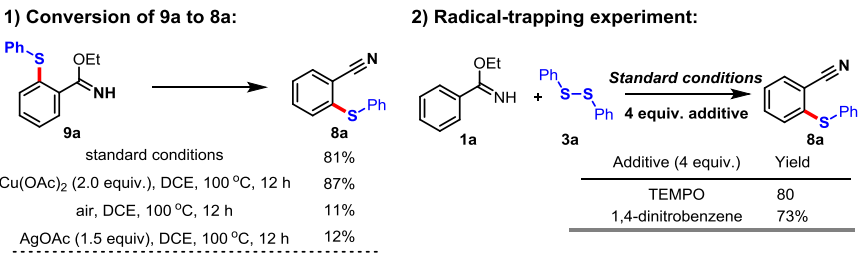

Scheme 9. Mechanistic studies.

Inspired by the related precedent literature, and the experimental observation, a tentative mechanism was proposed (Scheme 10). First, with the assistance of mono-N-protected amino acid (MPAA), ${ }^{6 i}, 14 \mathrm{C}-$ $\mathrm{H}$ activation of imidate ester $1 \mathrm{a}$ took place, to give rhodacycle species A. Subsequent oxidative Heck reaction led to intermediate $\mathbf{C}$ or $\mathbf{C}^{\prime}$ via second $\mathrm{C}-\mathrm{H}$ activation, which facilitated further reaction with sulfide species $\mathbf{D}$ generated from disulfide $\mathbf{3}$, affording to key intermediate E. Finally, the desired multiple $\mathrm{C}-\mathrm{H}$ activation products $\mathbf{5}$ or $\mathbf{4}$ were released via C-S bond reductive elimination, and reoxidation of the released $\mathrm{Rh}(\mathrm{I})$ species by $\mathrm{Ag}(\mathrm{I})$ or $\mathrm{Cu}(\mathrm{II})$ oxidant. When with key intermediate $\mathbf{C}$, dual cross-dehydrogenative coupling reaction of imidate ester with arene and terminal olefins, could also proceed with the assistance of PivOH and oxidant, affording to the multiple functionalized products 7 .

Notably, when disulfides $\mathbf{3}$ were subjected into reaction prior to terminal olefins $\mathbf{2}, \mathrm{C}-\mathrm{H}$ sulfenylation took place to give $\mathbf{9}$. However, the overcoordination of imidate ester and thioether group to $\mathrm{Rh}$ (III) led to deactivation of $\mathrm{Rh}(\mathrm{III})$ catalyst, and thus, no second $\mathrm{C}-\mathrm{H}$ activation proceed.

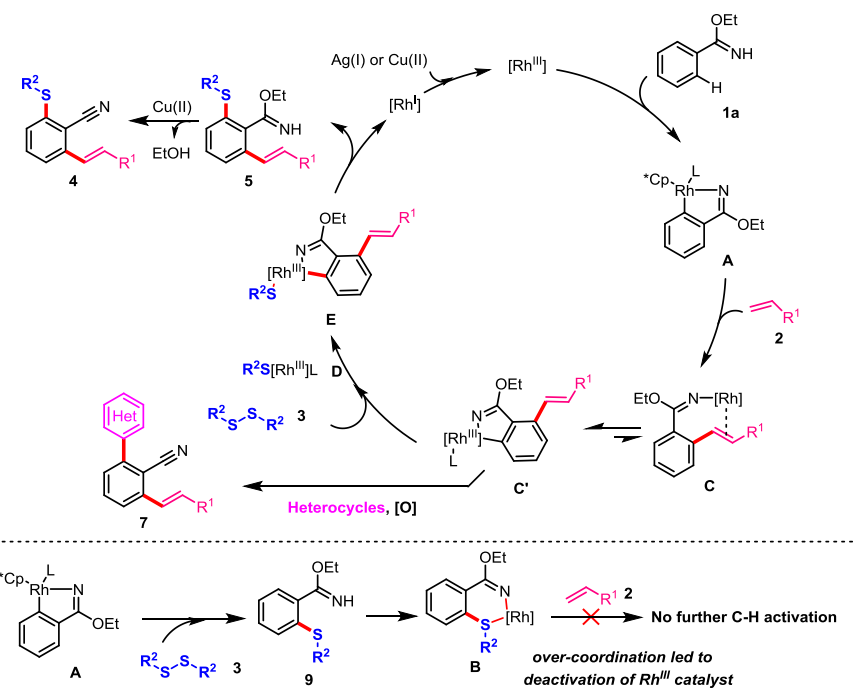

Scheme 10. Proposed Mechanism

\section{Conclusions}

In summary, by judicious choice of versatile imidate esters as the key directing groups, multiple $\mathrm{C}-\mathrm{H}$ activation was developed, leading to poly-functionalized arenes. Significantly, dual crossdehydrogenative coupling between imidate esters, terminal olefins and heterocycles, via sequential $\mathrm{C}-\mathrm{H}$ activation, was also achieved under $\mathrm{Rh}$ (III) catalysis. The use of $\mathrm{Ag}(\mathrm{I})$ or $\mathrm{Cu}$ (II) salt switched the selectivity in $\mathrm{C}-\mathrm{H}$ sulfenylation of synthetically valuable imidate esters, which facilitated the rapid construction of various Scontaining molecular libraries. Further synthetic application was demonstrated by late-stage modification of pharmaceuticals and advanced materials, as well as expedient construction of biologically active molecules. This sequential $\mathrm{C}-\mathrm{H}$ activation strategy might provide valuable insight into expedient delivery of highly functionalized pharmaceuticals and materials.

\section{Conflicts of interest}

There are no conflicts to declare.

\section{Acknowledgements}

We are grateful for the financial supported by the National Natural Science Foundation of China (No. 22071034, 21602032), Science and Technology Planning of Guangdong Province (No. 2019A050510042), the One Hundred Young Talent Program of Guangdong University of 
Technology and GDUT Analysis and Test Center for the HRMS analysis.

\section{Notes and references}

1 (a) Z. Tomović, J. van Dongen, S. J. George, H. Xu, W. Pisula, P. Leclère, M. M. J. Smulders, S. De Feyter, E. W. Meijer, A. P. H. J. Schenning, J. Am. Chem. Soc., 2007, 29, 16190-16196; (b) Y. Geng, A. Fechtenkötter, K. Müllen, J. Mater. Chem., 2001, 11, 1634-1641; (c) S. Suzuki, Y. Segawa, K. Itami, J. Yamaguchi, Nat. Chem., 2015, 7, 227-233; (d) Y. Koga, T. Kaneda, Y. Saito, K. Murakami, K. Itami, Science 2018, 359, 435-439.

2 (a) M. Catellani, E. Motti, N. Della Ca', Acc. Chem. Res., 2008, 41, 1512-1522; (b) J. Ye, M. Lautens, Nat. Chem., 2015, 7, 863-870; (c) J. Wang; G. Dong, Chem. Rev., 2019, 119, 7478-7528.

3 For reviews: (a) M. Murai, K. Takai, Synthesis 2019, 51, 40-54; (b) K. Ghosh, R. K. Rit, M. Shankar, K. Mukherjee, A. K. D. Sahoo, Chem. Rec., 2020, 20, 1017-1042.

4 (a) J. Wencel-Delord, F. Glorius, Nat. Chem., 2013, 5, 369-375; (b) S. Tani, T. N. Uehara, J. Yamaguchi, K. Itami, Chem. Sci., 2014, 5, 123-135; (c) Y. Segawa, T. Maekawa, K. Itami, Angew. Chem., Int. Ed., 2015, 54, 66-81; (d) J. Yin, J. You, Angew. Chem., Int Ed., 2019, 58, 302-306.

5 (a) X. Li, J. Rao, W. Ouyang, Q. Chen, N. Cai, Y.-J. Lu, Y. Huo, ACS Catal., 2019, 9, 8749-8756; (b) X. Li, W. Ouyang, J. Nie, S. Ji, Q. Chen. Y. Huo, ChemCatChem 2020, 12, 2358-2384; (c) W. Ouyang, J. Rao, Y. Li, X. Liu, Y. Huo, Q. Chen, X. Li, Adv. Synth. Catal., 2020, 362, 5576-5600. For selected examples on imidate esters assisted C-H activation: (d) D.-G. Yu, M. Suri, F. Glorius, J. Am. Chem. Soc., 2013, 135, 8802-8805; (e) X. Wang, N. Jiao, Org. Lett., 2016, 18, 2150-2153; (f) N. Lv, Z. Chen, Y. Liu, Z. Liu, Y. Zhang, Org. Lett. 2017, 19, 2588-2591; (g) X. Wu, H. Xiong, S. Sun, J. Cheng, Org. Lett., 2018, 20, 1396; (h) X. Wang, A. Lerchen, F. Glorius, Org. Lett. 2016, 18, 2090-2093. (i) J. Park, J. Lee, S. Chang, Angew. Chem., Int. Ed., 2017, 56, 4256-4260. (j) S. Yu, G. Tang, Y. Li, X. Zhou, Y. Lan, X. Li, Angew. Chem., Int. Ed., 2016, 55, 8696-8700.

6 (a) L. D. Tran, I. Popov, O. Daugulis, J. Am. Chem. Soc., 2012, 134, 18237-18240; (b) Y. Yang, W. Hou, L. Qin, J. Du, H. Feng, B. Zhou, Y. Liu, Chem. Eur. J., 2014, 20, 416-420; (c) X. Li, Y. Xu, W. Wu, C. Jiang, C. Qi, H. Jiang, Chem. -Eur. J., 2014, 20, 79117915; (d) C. Lin, D. Li, B. Wang, J. Yao, Y. Zhang, Org. Lett., 2015, 17, 1328-1331; (e) X. Ye, J. L. Petersen, X. Shi, Chem. Commun., 2015, 51, 7863-7866; (f) S.-Y. Yan, Y.-J. Liu, B. Liu, Y.-H. Liu, B.F. Shi, Chem. Commun., 2015, 51, 4069-4072; (g) K. Yang, Y. Wang, X. Chen, A. A. Kadi, H.-K. Fun, H. Sun, Y. Zhang, H. Lu, Chem. Commun., 2015, 51, 3582-3585. (h) C. Liu, Y. Fang, S.-Y. Wang, S.-J. Ji, ACS Catal., 2019, 9, 8910-8915; (i) Y.-S. Kang, P. Zhang, M.-Y. Li, Y.-K. Chen, H.-J. Xu, J. Zhao, W.-Y. Sun, J.-Q. Yu, Y. Lu, Angew. Chem., Int. Ed., 2019, 58, 9099-9103; (j) W. Ma, N. Kaplaneris, X. Fang, L. Gu, R. Mei, L. Ackermann, Org. Chem. Front., 2020, 7, 1022-1060.

7 (a) D. A. Colby, R. G. Bergman, J. A. Ellman, Chem. Rev., 2010, 110, 624-655; (b) T. Satoh, M. Miura, Chem. -Eur. J., 2010, 16 11212-11222; (c) G. Song, F. Wang, X. Li, Chem. Soc. Rev., 2012, 41, 3651-3678; (d) G. Song, X. Li, Acc. Chem. Res., 2015, 48 1007-1020; (e) B. Ye, N. Cramer, Acc. Chem. Res., 2015, 48, 1308-1318; (f) T. Gensch, M. N. Hopkinson, F. Glorius, J. Wencel-Delord, Chem. Soc. Rev., 2016, 45, 2900-2936; (g) T. Piou, T. Rovis, Acc. Chem. Res., 2018, 51, 170-180; (h) P. Gandeepan, T. Müller, D. Zell, G. Cera, S. Warratz, L. Ackermann, Chem. Rev., 2019, 119, 2192-2452; (i) S. Rej, N. Chatani, Angew. Chem., Int. Ed., 2019, 58, 8304-8329.

8 Gu and Dong independently reported simultaneous construction of C-C and C-S bonds using Catellani reaction: (a) F. Sun, M. Li, C. He, B. Wang, B. Li, X. Sui, Z. Gu, J. Am. Chem. Soc., 2016, 138,
7456-7459; (b) R. Li, Y. Zhou, K.-Y. Yoon, Z. Dong, G. Dong, Nat. Commun., 2019, 10, 3555-3562.

9 (a) C-J. Li, Acc. Chem. Res., 2009, 42, 335-344; (b) Y. Yang, J. Lan, J. You, Chem. Rev., 2017, 117, 8787-8863.

10 (a) I. P. Beletskaya, V. P. Ananikov, Chem. Rev., 2011, 111, 15961636; (b) C. Shen, P. Zhang, Q. Sun, S. Bai, T. S. A. Hor, X. Liu, Chem. Soc. Rev., 2015, 44, 291-314; (c) M. Feng, B. Tang, S. Liang, X. Jiang, Curr. Top. Med. Chem., 2016, 16, 1200-1216; (d) P. Devendar, G.-F. Yang, Top. Curr. Chem., 2017, 375, 82-115; (e) E. K. Lee, M. Y. Lee, C. H. Park, H. R. Lee, J. H. Oh, Adv. Mater., 2017, 29, 1703638-1703666; (f) K. A. Scott, J. T. Njardarson, Top. Curr. Chem., 2018, 376, 5-38.

11 For nitrile template guided meta $\mathrm{C}-\mathrm{H}$ functionalization: (a) D. Leow, G. Li, T. S. Mei, J.-Q. Yu, Nature 2012, 486, 518-522. (b) Y.-F. Yang, G.-J. Cheng, P. Liu, D. Leow, T.-Y. Sun, P. Chen, X. Zhang, J.-Q. Yu, Y.-D. Wu, K. N. Houk, J. Am. Chem. Soc., 2014, 136, 344-355. For reviews on nitriles directed $\mathrm{C}-\mathrm{H}$ activation: (c) P. Gandeepan, C.-H. Cheng. Chem. Asian J., 2015, 10, 824838; (d) Y. Ping, L. Wang, Q. Ding, Y. Peng, Adv. Synth. Catal., 2017, 359, 3274-3291.

12 (a) M. Pawliczek, L. K. B. Garve, D. B. Werz, Org. Lett., 2015, 17, 1716-1719; (b) Y. Zhou, Y. Wang, Y. Lou, Q. Song, Chem. Commun., 2019, 55, 10265-10268.

13 (a) Y.-J. Liu, H. Xu, W.-J. Kong, M. Shang, H.-X. Dai, J.-Q. Yu, Nature 2014, 515, 389-393; (b) H. Wang, M. M. Lorion, L. Ackermann, Angew. Chem., Int. Ed., 2016, 55, 10386-10390; (c) M. Shang, M.-M. Wang, T. G. Saint-Denis, M.-H. Li, H.-X. Dai, J.-Q. Yu, Angew. Chem., Int. Ed., 2017, 56, 5317-5321; (d) L.-L. Xu, X. Wang, B. Ma, M.-X. Yin, H.-X. Lin, H.-X. Dai, J.-Q. Yu, Chem. Sci., 2018, 9, 5160-5164.

14 (a) Y.-F. Yang, X. Hong, J.-Q. Yu, K. N. Houk, Acc. Chem. Res., 2017, 50, 2853-2860; (b) Q. Shao, K. Wu, Z. Zhuang, S. Qian, J.-Q. Yu, Acc. Chem. Res., 2020, 53, 833-851. 
Journal Name

Sequential multiple C-H activation

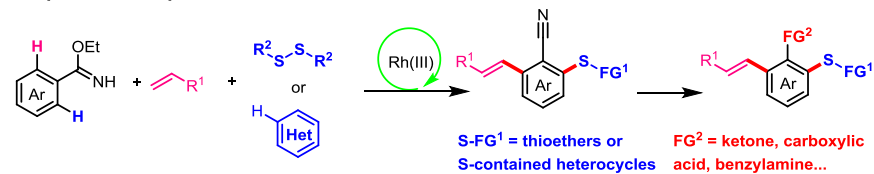




\section{Supporting Information}

Multiple C-H Activation Enabled Modular Construction of Densely Functionalized Sulfur-Contained Arenes

Wensen Ouyang, Jianhang Rao, Jie Wang, Yang Gao, Yanping Huo, Qian Chen, Xianwei Li* School of Chemical Engineering and Light Industry, Guangdong University of Technology, Guangzhou, 510006, China.

E-mail: xwli@gdut.edu.cn

Table of Contents

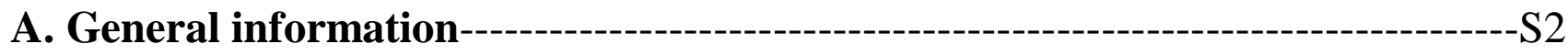

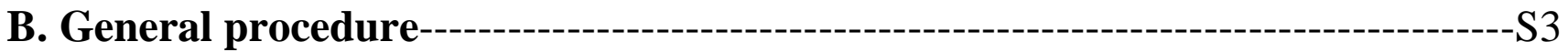

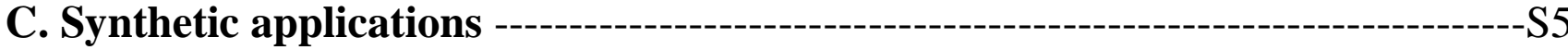

D. Preliminary mechanistic studies ---

E. Analytical data for the obtained products---

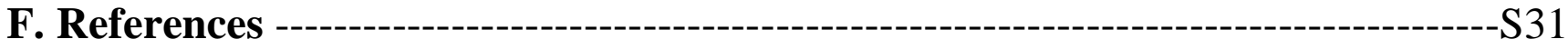

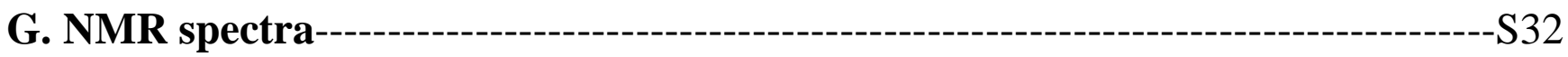




\section{A. General Information}

${ }^{1} \mathrm{H}$ and ${ }^{13} \mathrm{C}$ NMR spectra were recorded on BRUKER DRX-400 spectrometer using $\mathrm{CDCl}_{3}$ as solvent and TMS as an internal standard. Chemical shifts for ${ }^{1} \mathrm{H}$ NMR spectra are reported as $\delta$ in units of parts per million (ppm) downfield from $\mathrm{SiMe}_{4}(\delta 0.0)$ and relative to the signal of chloroform-d $(\delta 7.26$, singlet). Multiplicities were given as: s (singlet); d (doublet); t (triplet); q (quartet); dd (doublets of doublet); dt (doublets of triplet); dq (doublets of quartet). Coupling constants are reported as a $J$ value in Hz. Carbon nuclear magnetic resonance spectra $\left({ }^{13} \mathrm{C} \mathrm{NMR}\right)$ are reported as $\delta$ in units of parts per million (ppm) downfield from $\mathrm{SiMe}_{4}\left(\begin{array}{l}\delta \\ 0.0\end{array}\right)$ and relative to the signal of chloroform-d ( $\delta$ 77.0, triplet). Gas chromatograph mass spectra were obtained with a SHIMADZU model GCMS-QP 5000 spectrometer. HRMS was carried out on a MAT 95XP (Thermo). 


\section{B. General procedure:}

1) General procedure for the synthesis of arylimidates:

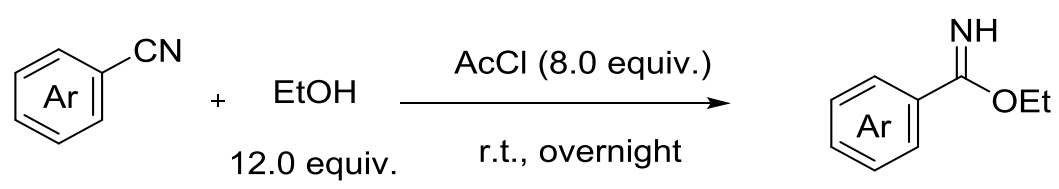

Figure S1. Synthesis of arylimidates.

To a stirred solution of a nitrile (1.0 equiv.) and an alcohol (12.0 equiv.), $\mathrm{AcCl}$ was added (8.0 equiv.) dropwise at $0{ }^{\circ} \mathrm{C}$. The Schlenk tube was stoppered tightly and the stirring was continued at $25^{\circ} \mathrm{C}$. After the reaction was complete monitored by TLC, the volatiles were removed under reduced pressure to isolate the benzimidate hydrochloride. Then slowly mixed benzimidate hydrochloride and saturated aqueous $\mathrm{NaHCO}_{3}$ solution inice bath, until gas evolution had ceased. The product was extracted into $\mathrm{Et}_{2} \mathrm{O}$ and the organic solution was washed with $\mathrm{H}_{2} \mathrm{O}$ and brine and concentrated under reduced pressure to obtain the benzimidates. The procedure was according to the reference: Yadav, V. K.; Babu, K. G. A Remarkably Efficient Markovnikov Hydrochlorination of Olefins and Transformation of Nitriles into Imidates by Use of AcCl and an Alcohol. Eur. J. Org. Chem. 2005, 452.

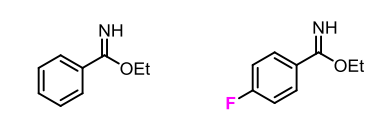

1a

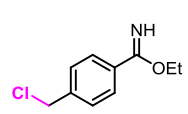

$1 i$

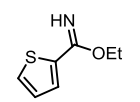

1j

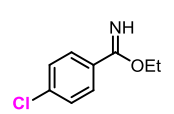

$1 c$

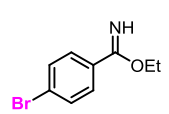

1d

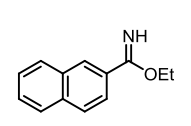

$1 k$
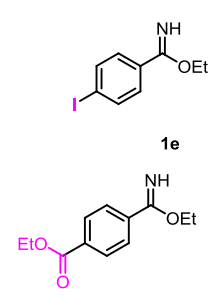

$1 \mathrm{~m}$

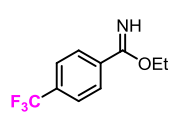

$1 f$

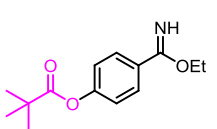

1n

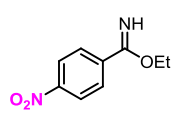

19

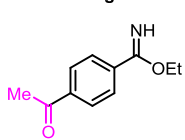

10

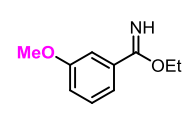

1h

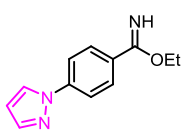

$1 \mathrm{p}$

Figure S2. Imidate ester substrates

\section{2) Synthesis of disulfides-1:}

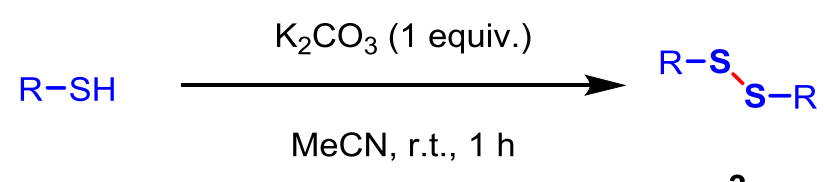

Figure S3. Synthesis of disulfides from thiols.

To a round bottle $(50 \mathrm{~mL})$ were added thiophenol $(5 \mathrm{mmol})$, anhydrous potassium carbonate $(0.69 \mathrm{~g}$, $5 \mathrm{mmol})$, and $\mathrm{MeCN}(10 \mathrm{~mL})$ sequentially, and the reaction was conducted at room temperature under air atmosphere for 1 hour. And the desired disulfides were obtained quantitatively, after filter and concentration. 


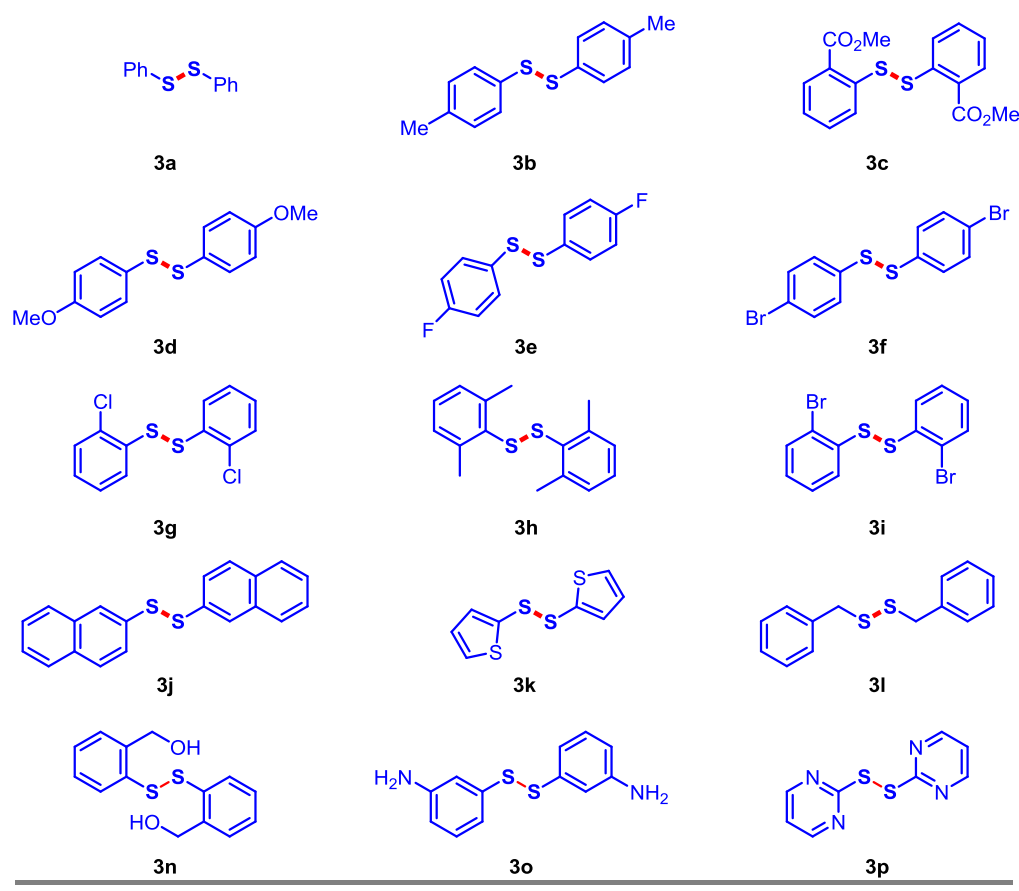

Figure S4. Disulfide substrates-1.

\section{Synthesis of disulfides-2:}

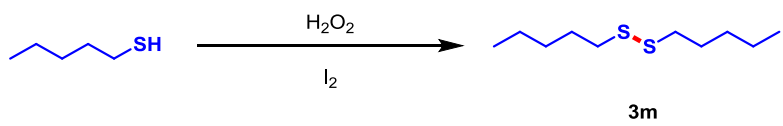

Figure S5. Disulfide substrates-2.

A round bottom flask was charged with $1 \% \mathrm{H}_{2} \mathrm{O}_{2}(1 \mathrm{mmol})$ and $\mathrm{I}_{2}(0.01 \mathrm{mmol})$. The thiol $(1 \mathrm{mmol})$ was added to the solution at room temperature with vigorous stirring. The reaction was monitored by TLC ( $\mathrm{n}$ hexane:ethyl acetate 15:3). After the completion of the reaction, the products were filtered off and dried or extracted with ethyl acetate $(3 \times 5 \mathrm{~mL})$. Then the combined organic phases were washed with water $(2$ $\times 4 \mathrm{~mL}$ ), separated, and dried with anhydrous $\mathrm{Na}_{2} \mathrm{SO}_{4}$. The solvent was evaporated under reduced pressure to obtain the corresponding disulfides.

\section{3) General procedure for the three component synthesis of multiple functionalized thioethers:} synthesis of multiple functionalized thioethers 4:

An oven-dried $10 \mathrm{~mL}$ Schlenk Tube was charged with imidates $1(0.1 \mathrm{mmol}),\left[\mathrm{RhCp}^{*} \mathrm{Cl}_{2}\right]_{2}(0.002$ mmol), $\operatorname{AgNTf}_{2}(0.008 \mathrm{mmol}), \mathrm{N}-\mathrm{Boc}-\mathrm{L}-\mathrm{Leu}-\mathrm{OH}(15 \mathrm{~mol} \%)$ and in sequence, followed by addition of terminal alkenes $2(0.15 \mathrm{mmol})$ in DCE $(1.0 \mathrm{~mL})$ through syringe. The resulting reaction mixture was stirred at $100{ }^{\circ} \mathrm{C}$ for $12 \mathrm{~h}$. And then, $\mathrm{Cu}(\mathrm{OAc})_{2} \cdot \mathrm{H}_{2} \mathrm{O}$ (2.0 equiv.), disulfides $3(0.15 \mathrm{mmol})$ in DCE $(0.5$ $\mathrm{mL}$ ) was inserted into the reaction system through syringe for another 12 hours. After that, the reaction 
mixture was diluted with $\mathrm{CH}_{2} \mathrm{Cl}_{2}$ and filtered through diatomite. Removing the solvent in vacuo and purification of the residue by silica gel column chromatography afforded the desired products 4 .

\section{Synthesis of multiple functionalized thioethers 5:}

An oven-dried $10 \mathrm{~mL}$ Schlenk Tube was charged with imidates $1(0.1 \mathrm{mmol}),\left[\mathrm{RhCp}^{*} \mathrm{Cl}_{2}\right]_{2}(0.002$ mmol), $\operatorname{AgNTf}_{2}(0.008 \mathrm{mmol}), \mathrm{N}-\mathrm{Boc}-\mathrm{L}-\mathrm{Leu}-\mathrm{OH}(15 \mathrm{~mol} \%)$ in sequence, followed by addition of terminal alkenes $2(0.15 \mathrm{mmol})$ in DCE $(1.0 \mathrm{~mL})$ through syringe. The resulting reaction mixture was stirred at $100{ }^{\circ} \mathrm{C}$ for $12 \mathrm{~h}$; And then, AgOAc (1.2 equiv.), disulfides 3 ( $\left.0.15 \mathrm{mmol}\right)$ in DCE (0.5 mL) was inserted into the reaction system through syringe for another 12 hours. After that, the reaction mixture was diluted with $\mathrm{CH}_{2} \mathrm{Cl}_{2}$ and filtered through diatomite. Removing the solvent in vacuo and purification of the residue by silica gel column chromatography afforded the desired products.

\section{4) General procedure for the synthesis of ortho-thioether aryl nitriles 8:}

An oven-dried $10 \mathrm{~mL}$ Schlenk Tube was charged with imidates $1(0.10 \mathrm{mmol}),\left[\mathrm{RhCp}^{*} \mathrm{Cl}_{2}\right]_{2}(0.002$ mmol), $\operatorname{AgNTf}_{2}(0.008 \mathrm{mmol})$ and $\mathrm{Cu}(\mathrm{OAc})_{2} \cdot \mathrm{H}_{2} \mathrm{O}$ (2.0 equiv.) in sequence, followed by addition of disulfides $3(0.15 \mathrm{mmol})$ in DCE $(1.0 \mathrm{~mL})$ through syringe. The resulting reaction mixture was stirred at $100{ }^{\circ} \mathrm{C}$ for $12 \mathrm{~h}$ and then diluted with $\mathrm{CH}_{2} \mathrm{Cl}_{2}$ and filtered through diatomite. Removing the solvent in vacuo and purification of the residue by silica gel column chromatography afforded the desired products 8.

\section{5) General procedure for the synthesis of thioethers 9:}

An oven-dried $10 \mathrm{~mL}$ Schlenk Tube was charged with imidates $1(0.10 \mathrm{mmol}),\left[\mathrm{RhCp}^{*} \mathrm{Cl}_{2}\right]_{2}(0.002$ mmol), $\operatorname{AgNTf}_{2}(0.008 \mathrm{mmol})$ and $\mathrm{AgOAc}(1.2$ equiv.) in sequence, followed by addition of disulfides 3 $(0.15 \mathrm{mmol})$ in DCE $(1.0 \mathrm{~mL})$ through syringe. The resulting reaction mixture was stirred at $100{ }^{\circ} \mathrm{C}$ for $12 \mathrm{~h}$ and then diluted with $\mathrm{CH}_{2} \mathrm{Cl}_{2}$ and filtered through diatomite. Removing the solvent in vacuo and purification of the residue by silica gel column chromatography afforded the desired products 9 . 


\section{Synthetic applications}

\section{1) Sequential $\mathrm{C}-\mathrm{H}$ sulfenylation and $\mathrm{C}-\mathrm{H}$ arylation: synthesis of dibenzo[b,d]thiophene-4-carbonitrile 15}

Product 8t was obtained through standard conditions via $\mathrm{Rh}$ (III) catalysis: An oven-dried $10 \mathrm{~mL}$ Schlenk Tube was charged with imidates $1 \mathbf{a}(0.10 \mathrm{mmol}),\left[\mathrm{RhCp}^{*} \mathrm{Cl}_{2}\right]_{2}(0.002 \mathrm{mmol}), \operatorname{AgNTf}_{2}$ ( $0.008 \mathrm{mmol}), \mathrm{Cu}(\mathrm{OAc})_{2} \cdot \mathrm{H}_{2} \mathrm{O}$ (2.0 equiv.) in sequence, followed by addition of disulfides $3 \mathbf{i}(0.15 \mathrm{mmol})$ in DCE $(1.0 \mathrm{~mL})$ through syringe. The resulting reaction mixture was stirred at $100^{\circ} \mathrm{C}$ for $12 \mathrm{~h}$ and then diluted with $\mathrm{CH}_{2} \mathrm{Cl}_{2}$ and filtered through diatomite. Removing the solvent in vacuo and purification of the residue by silica gel column chromatography afforded the desired product $\mathbf{8 t}$.

With product $8 \mathbf{t}(0.3 \mathrm{mmol}), \mathrm{PdCl}_{2}\left(\mathrm{PPh}_{3}\right)_{2}(0.006 \mathrm{mmol}), \mathrm{KOPiv}$ (2 equiv.) in DMA ( $N, N$-dimethyl acetamide) $(1 \mathrm{~mL})$ in an oven-dried Schlenk tube under $140{ }^{\circ} \mathrm{C}$, and the reaction was conducted for 12 hours. After reaction finished, the solution was washed with brine $(20 \mathrm{~mL} \times 2)$, and extracted with ethyl acetate $(20 \mathrm{~mL} \times 2)$, and obtained solution was concentrated and purification of the residue by silica gel column chromatography afforded the desired product 15 (Figure S6).

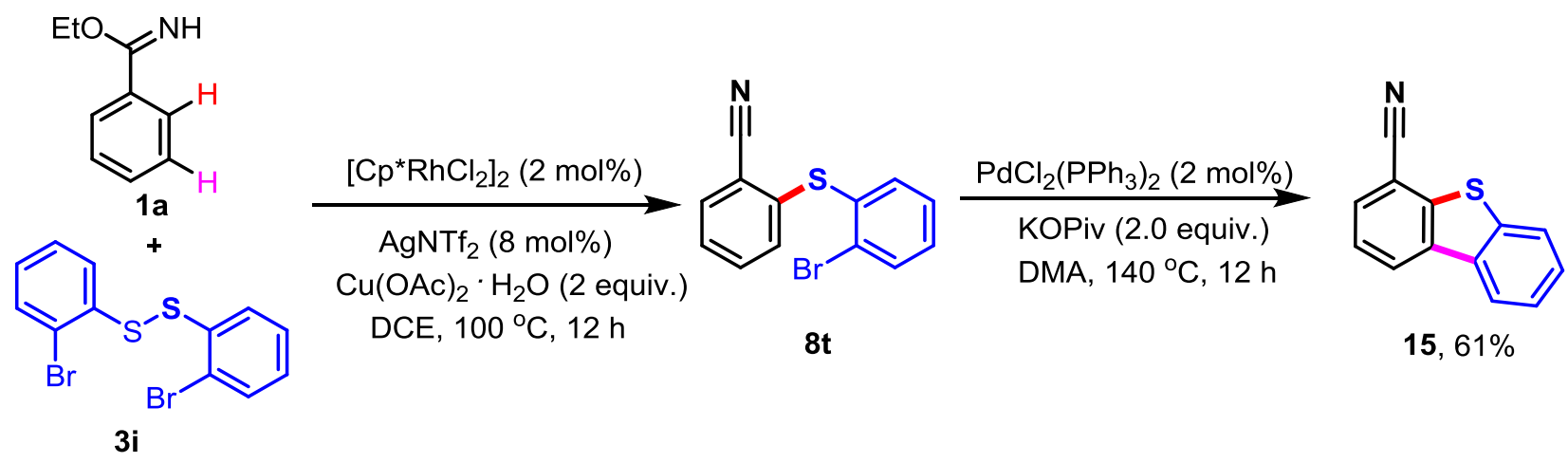

Figure S6. Sequential C-H activation: synthesis of dibenzo[b,d]thiophene-4-carbonitrile 15

\section{2) Rapid synthesis of Madam dihydrochloride analogue 16:}

An oven-dried $10 \mathrm{~mL}$ Schlenk Tube was charged with imidates $1 \mathbf{a}(0.1 \mathrm{mmol}),\left[\mathrm{RhCp}^{*} \mathrm{Cl}_{2}\right]_{2}(0.002$ mmol), $\operatorname{AgNTf}_{2}(0.008 \mathrm{mmol})$ and $\mathrm{AgOAc}$ (1.2 equiv.) in sequence, followed by addition of disulfides $30(0.20 \mathrm{mmol})$ in DCE $(1.0 \mathrm{~mL})$ through syringe. The resulting reaction mixture was stirred at $100{ }^{\circ} \mathrm{C}$ for $12 \mathrm{~h}$. After that, the reaction mixture was diluted with $\mathrm{CH}_{2} \mathrm{Cl}_{2}$ and filtered through diatomite. Removing the solvent in vacuo and purification of the residue by silica gel column chromatography afforded the desired product 16 (Figure S7). 


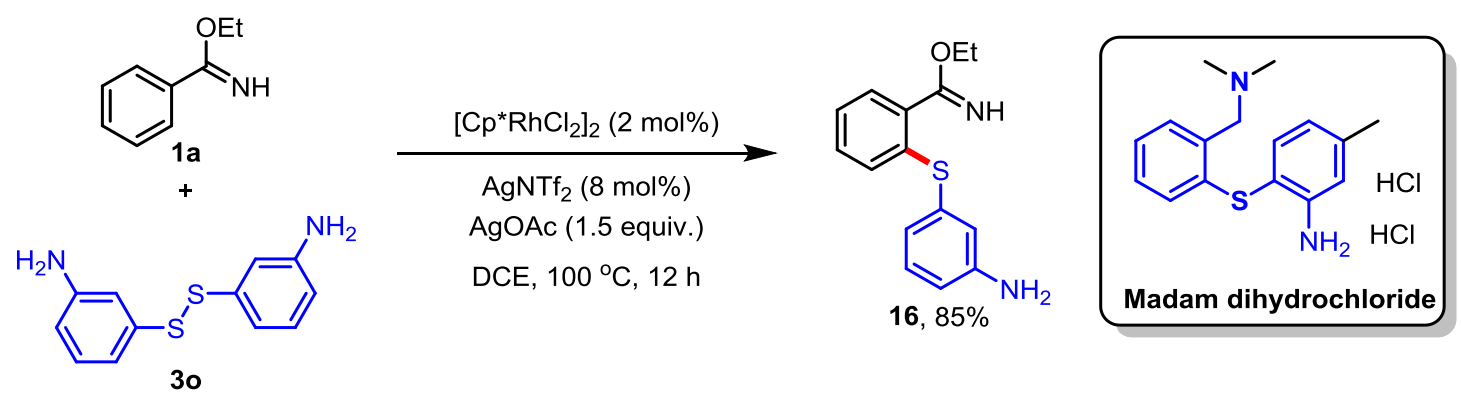

Figure S7. Concise synthesis of 16

\section{3) Expedient delivery of Bipenamol:}

\section{Synthesis of intermediate 17:}

An oven-dried $10 \mathrm{~mL}$ Schlenk Tube was charged with imidates $1 \mathrm{a}(0.1 \mathrm{mmol}),\left[\mathrm{RhCp}^{*} \mathrm{Cl}_{2}\right]_{2}(0.002$ mmol), $\operatorname{AgNTf}_{2}(0.008 \mathrm{mmol})$ and $\mathrm{Cu}(\mathrm{OAc})_{2} \cdot \mathrm{H}_{2} \mathrm{O}(2.0$ equiv. $)$ in sequence, followed by addition of disulfides 3n $(0.15 \mathrm{mmol})$ in DCE $(1.0 \mathrm{~mL})$ through syringe. The resulting reaction mixture was stirred at $100{ }^{\circ} \mathrm{C}$ for $12 \mathrm{~h}$. After that, the reaction mixture was diluted with $\mathrm{CH}_{2} \mathrm{Cl}_{2}$ and filtered through diatomite. Removing the solvent in vacuo and purification of the residue by silica gel column chromatography afforded the desired product 17.

\section{Synthesis of Bipenamol 18:}

To a round bottle was added product $17(0.2 \mathrm{mmol})$ in THF $(2 \mathrm{~mL})$, which was further added $\mathrm{LiAlH}_{4}$ (4 equiv.), the obtained solution was heated to $120{ }^{\circ} \mathrm{C}$ for 10 minutes. After the reaction was cooled to room temperature, water $(20 \mathrm{~mL})$ was added, and the reaction mixture was extracted with ethyl acetate and filtered through diatomite. Removing the solvent in vacuo and purification of the residue by silica gel column chromatography afforded the desired product 18 (Figure S8).

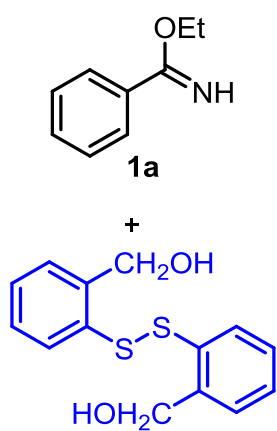

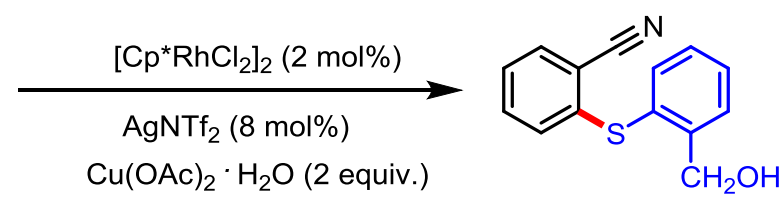

DCE, $100{ }^{\circ} \mathrm{C}, 12 \mathrm{~h}$

$17,85 \%$

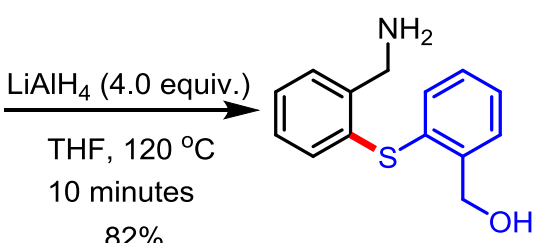

18, Bipenamol

Figure S8. Concise synthesis of Bipenamol 18 


\section{Preliminary mechanism studies:}

To obtain some insight into this multiple cascade reaction, we conducted the following experiments:

1) Conversion of thioether product 9a to 8a (Figure S9):

To elucidate the role of metal salts such as $\mathrm{AgOAc}$ and $\mathrm{Cu}(\mathrm{OAc})_{2} \bullet \mathrm{H}_{2} \mathrm{O}$ for the generation of imidate ester or nitrile substituted thioethers, first, we found that product 8a could be obtained in high efficiency under standard conditions. Control experiments revealed that $\mathrm{Cu}(\mathrm{OAc})_{2} \cdot \mathrm{H}_{2} \mathrm{O}$ was crucial for the conversion of product 9a to 8a, while air or AgOAc exhibited low conversion.

These observations indicated that $\mathrm{Cu}$ (II) salt was essential for the generation of nitrile substituted aryl thioethers. It was speculated that silver exhibited stronger Lewis acidity, which might favor the imidate ester functionality remained intact, while $\mathrm{Cu}$ (II) salt might promote the release of ethol moiety from the corresponding imidate ester products.

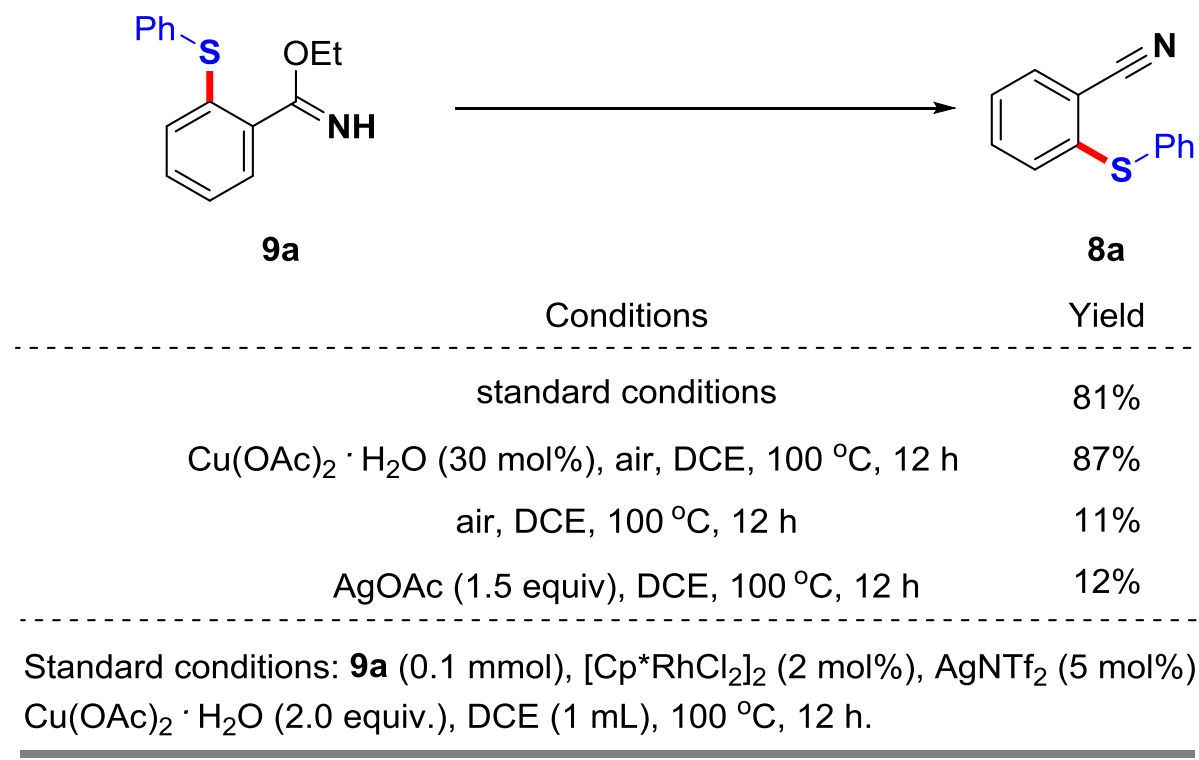

Figure S9. Conversion of 9a to 8a

2) To gain some insight into this transformation that if radical process was involved, some radicalscavenger studies were conducted.

Procedure: To a $25 \mathrm{~mL}$ Schlenk tube equipped with a magnetic stirring bar was added the substrate 1a $(0.1 \mathrm{mmol}),\left[\mathrm{RhCp}^{*} \mathrm{Cl}_{2}\right]_{2}(2.5 \mathrm{mg}, 0.002 \mathrm{mmol}), \mathrm{AgNTf}_{2}(0.008 \mathrm{mmol})$ and $\mathrm{Cu}(\mathrm{OAc})_{2} \cdot \mathrm{H}_{2} \mathrm{O}(2.0$ equiv. $)$ in sequence under $\mathrm{N}_{2}$ atmosphere, followed by addition of disulfide $\mathrm{PhSSPh} 3 \mathbf{a}$ (25.0 mg, $\left.0.15 \mathrm{mmol}\right)$ in DCE $(1.0 \mathrm{~mL})$ through syringe. The tube was capped, and heated to $100{ }^{\circ} \mathrm{C}$ for $12 \mathrm{~h}$. After cooled to room temperature, the reaction mixture was filtered through a pad of Celite. The filtrate was concentrated in vacuo to afford crude product, which was analyzed with ${ }^{1} \mathrm{H} \mathrm{NMR}$ using $\mathrm{CH}_{2} \mathrm{Br}_{2}$ as the internal standard. 
The results revealed that radical or an electron scavenger TEMPO and 1,4-dinitrobenzene showed no significant inhibition for the generation of the desired thioether product $\mathbf{8 a}$. These experiments indicated that single-electron transfer (SET) pathway might not be involved in this transformation (Figure S10).

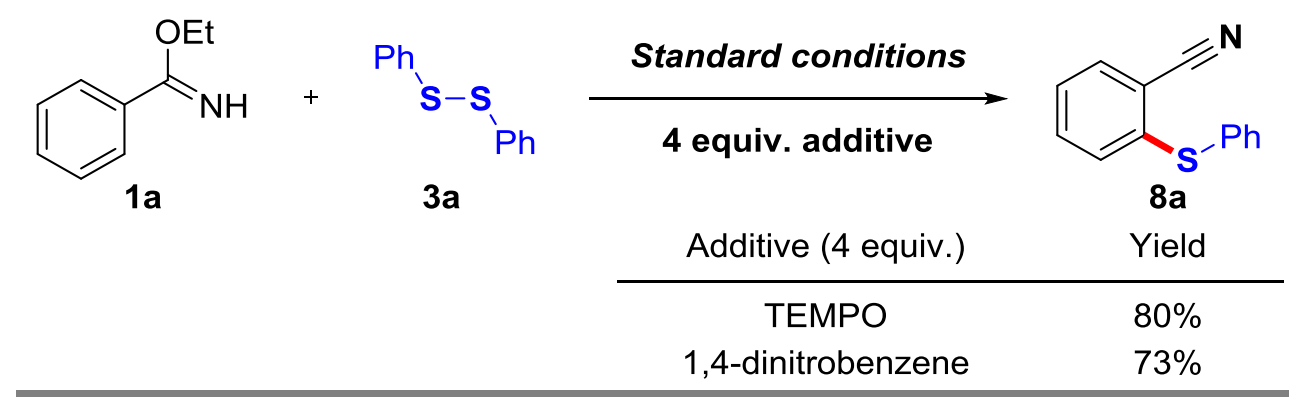

Figure S10. Radical-trapping experiment

3) According to the literatures and experimental observations, a tentative mechanism was proposed in Figure S11. It was speculated that coordination of imidate ester with $\mathrm{Rh}(\mathrm{III})$ took place to initate this transformation, which followed by $\mathrm{C}-\mathrm{H}$ activation to give the key 5 -membered rhodacycle intermediate A. Subsequent nucleophic substitution with disulfide 3a, giving to the desired ortho $\mathrm{C}-\mathrm{H}$ sulfenylation product 9a or 8a (path a), depending on the $\mathrm{Ag}(\mathrm{I})$ or $\mathrm{Cu}(\mathrm{II})$ salt added to the reaction system, together with rodium intermediate B-1. According to the control experiments depicted in Figure S9, the in situ generated ortho imidate ester substituted aryl thioethers $\mathbf{9}$ could also converted to the thioethers 8 . Further reaction of intermediate $B$ with imidate ester substrate 1a led to $\mathrm{Rh}(\mathrm{III})$ species $\mathrm{D}$, which underwent reductive elimination to afford the desired thioether products $8 \mathbf{a}$ or $\mathbf{9 a}$, and the released $\mathrm{Rh}(\mathrm{I}) \operatorname{species}$ was re-oxidzed to reactive $\mathrm{Rh}(\mathrm{III})$ catalyst by $\mathrm{Ag}(\mathrm{I})$ or $\mathrm{Cu}(\mathrm{II})$.

Alternatively, the in situ generated 5-membered rhodacycle intermediate A might undergo oxidative addition with disulfide $\mathbf{3 a}$ to give $\mathrm{Rh}(\mathrm{V})$ intermediate $\mathbf{C}$, which followed by reductive elimination to give the desired product $\mathbf{8 a}$ or $\mathbf{9 a}$ and rhodium species $\mathbf{B}-\mathbf{- 1}$. 

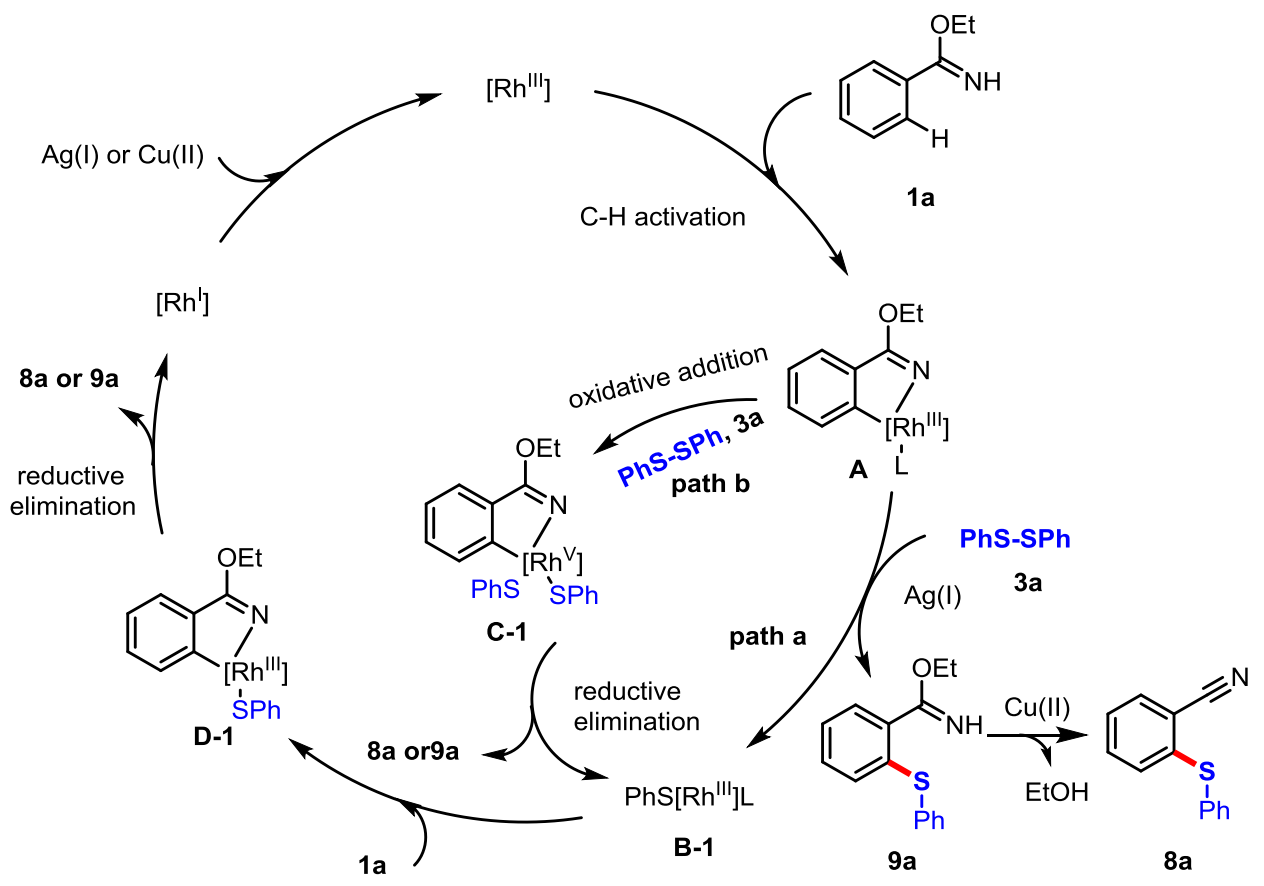

Figure S11. Proposed Mechanism for the Divergent Construction of thioethers.

For the multiple C-H activation reactions, a tentative mechanism was proposed (Figure S12). First, with the assistance of mono-N-protected amino acid (MPAA), $\mathrm{C}-\mathrm{H}$ activation of imidate ester 1a took place, to give rhodacycle species A. Subsequent oxidative Heck reaction led to intermediate $\mathbf{C}$ or $\mathbf{C}^{\prime}$ via second $\mathrm{C}-\mathrm{H}$ activation, which facilitated further reaction with sulfide species $\mathbf{D}$ generated from disulfide 3, affording to key intermediate E. Finally, the desired multiple $\mathrm{C}-\mathrm{H}$ activation products $\mathbf{5}$ or $\mathbf{4}$ were released via C-S bond reductive elimination, and reoxidation of the released $\mathrm{Rh}(\mathrm{I})$ species by $\operatorname{Ag}(\mathrm{I})$ or $\mathrm{Cu}$ (II) oxidant. When with key intermediate $\mathbf{C}$, dual cross-dehydrogenative coupling reaction of imidate ester with arene and terminal olefins, could also proceed with the assistance of PivOH and oxidant, affording to products 7 .

Notably, when disulfides 3 were subjected into reaction prior to terminal olefins $\mathbf{2}$, C-H sulfenylation took place to give 9. However, the overcoordination of imidate ester and thioether group to Rh(III) led to deactivation of $\mathrm{Rh}$ (III) catalyst, and thus, no second $\mathrm{C}-\mathrm{H}$ activation proceed. 


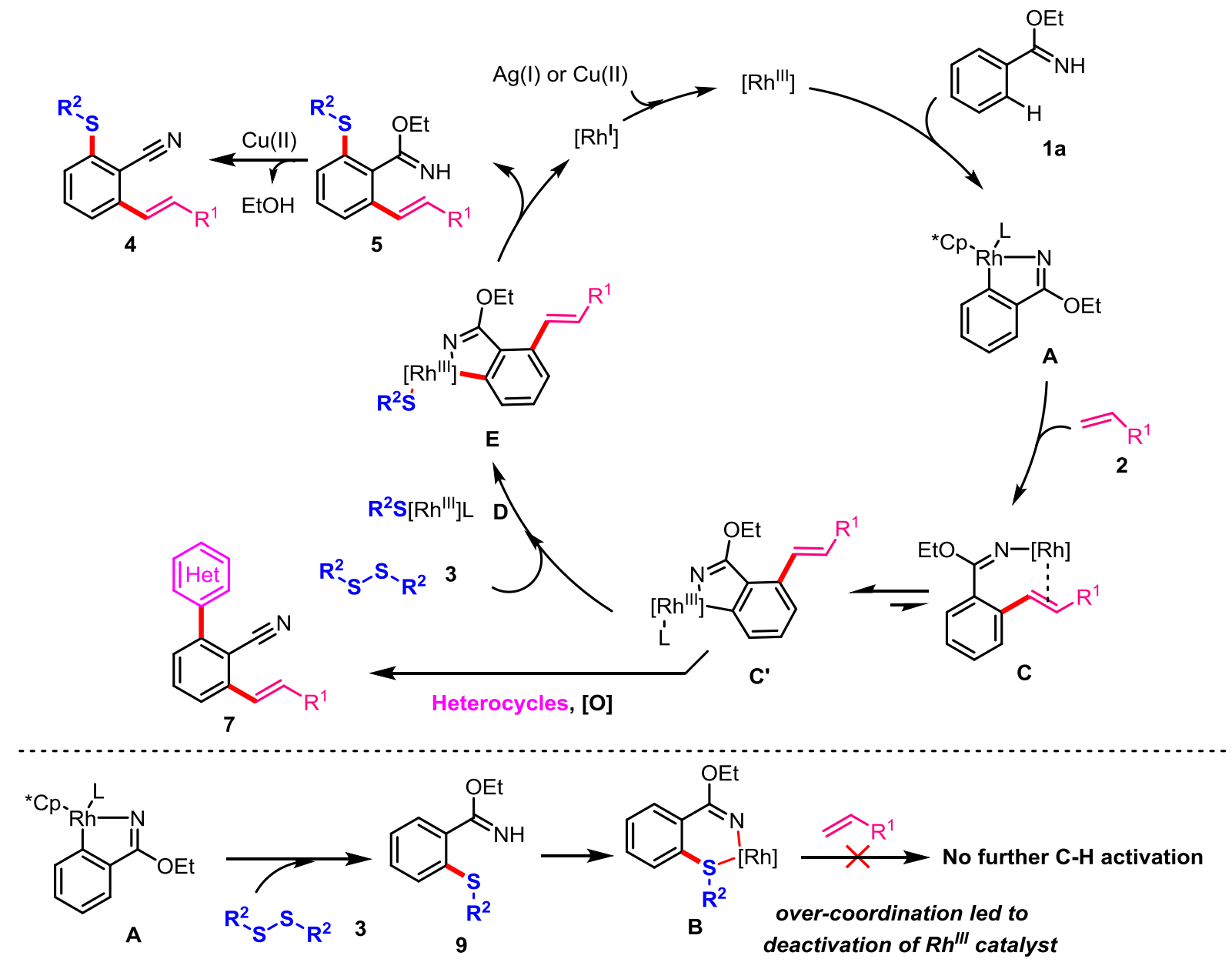

Figure S12. Proposed Mechanism. 


\section{E. Analytical data for the obtained products:}

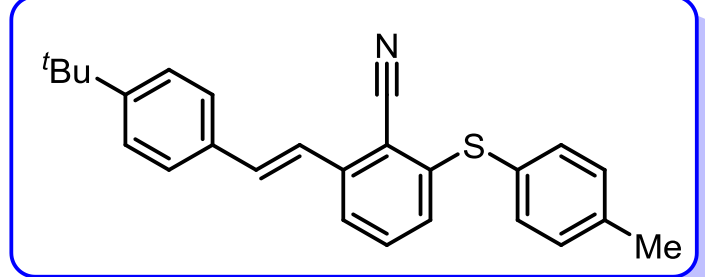

(E)-2-(4-(tert-Butyl)styryl)-6-(p-tolylthio)benzonitrile (4a), ${ }^{1} \mathrm{H}$ NMR (400 $\left.\mathrm{MHz}, \mathrm{CDCl}_{3}\right) \delta$ 7.55-7.51 $(\mathrm{m}, 3 \mathrm{H}), 7.43-7.40(\mathrm{~m}, 5 \mathrm{H}), 7.34-7.30(\mathrm{~m}, 1 \mathrm{H}), 7.25-7.22(\mathrm{~m}, 3 \mathrm{H}), 6.88(\mathrm{~d}, J=7.6 \mathrm{~Hz}, 1 \mathrm{H}), 2.40(\mathrm{~s}, 3 \mathrm{H})$, 1.35 (s, 9H), ${ }^{13} \mathbf{C}$ NMR (100 MHz, CDCl $) \delta$ 152.2, 144.2, 142.2, 139.4, 134.3, 133.7, 133.4, 132.3, 130.6, 126.9, 125.8, 123.3, 122.0, 34.7 31.2, 21.3. HRMS (ESI-TOF) m/z: $[\mathrm{M}+\mathrm{H}]^{+}$Calcd for $\mathrm{C}_{26} \mathrm{H}_{26} \mathrm{NS}$ : 384.1780, Found: 384.1783.

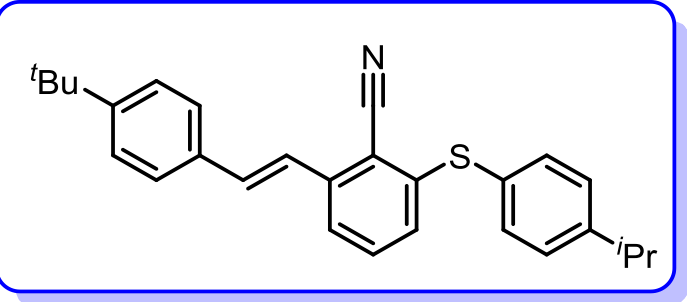

(E)-2-(4-(tert-Butyl)styryl)-6-((4-isopropylphenyl)thio)benzonitrile (4b), ${ }^{1} \mathrm{H}$ NMR (400 MHz, CDCl 3$) \delta 7.78(\mathrm{~d}, J=8.0 \mathrm{~Hz}, 1 \mathrm{H}), 7.63(\mathrm{~d}, J=8.0 \mathrm{~Hz}, 1 \mathrm{H}), 7.58-7.53(\mathrm{~m}, 1 \mathrm{H}), 7.54-7.51(\mathrm{~m}, 3 \mathrm{H}), 7.46-$ $7.44(\mathrm{~m}, 1 \mathrm{H}), 7.42-7.40(\mathrm{~m}, 3 \mathrm{H}), 7.33-7.28(\mathrm{~m}, 2 \mathrm{H}), 7.26-7.20(\mathrm{~m}, 1 \mathrm{H}), 2.68(\mathrm{q}, J=7.6 \mathrm{~Hz}, 1 \mathrm{H}), 1.36(\mathrm{~d}$, $J=2.4 \mathrm{~Hz}, 3 \mathrm{H}), 1.35(\mathrm{~s}, 9 \mathrm{H}), 1.27(\mathrm{~d}, J=7.2 \mathrm{~Hz}, 3 \mathrm{H}),{ }^{13} \mathbf{C} \mathbf{N M R}\left(\mathbf{1 0 0} \mathbf{M H z}, \mathbf{C D C l}_{3}\right) \delta$ 152.2, 145.7, 144.2 , 142.2, 140.8, 134.3, 133.7, 133.4, 133.3, 133.1, 132.7, 132.3, 129.4, 127.3, 126.9, 125.8, 125.2, 123.3, 122.1, 118.0, 115.9, 111.1, 34.7, 31.2, 28.6, 15.3. HRMS (ESI-TOF) m/z: [M $+\mathrm{H}]^{+}$Calcd for $\mathrm{C}_{28} \mathrm{H}_{30} \mathrm{NS}: 412.2093$, Found: 412.2095 .

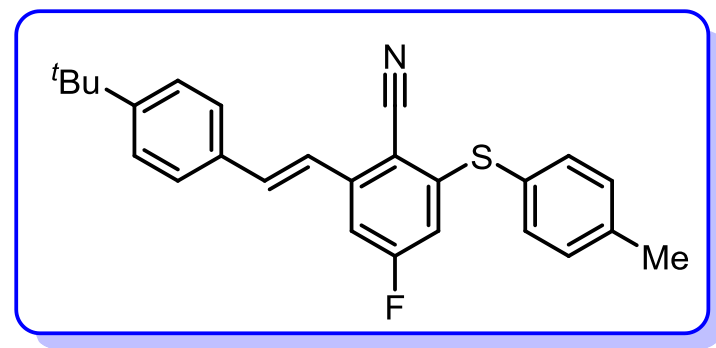

(E)-2-(4-(tert-Butyl)styryl)-4-fluoro-6-(p-tolylthio)benzonitrile (4c), ${ }^{1} \mathrm{H}$ NMR (400 MHz, CDCl 3$) \delta$ 7.55-7.51 (m, 2H), 7.47-7.42 (m, 4H), 7.38-7.36 (m, 1H), 7.27 (d, $J=8.0 \mathrm{~Hz}, 2 \mathrm{H}), 7.22(\mathrm{~d}, J=16.0 \mathrm{~Hz}$, 1H), $7.16(\mathrm{dd}, J=2.4 \mathrm{~Hz}, 9.6 \mathrm{~Hz}, 1 \mathrm{H}), 6.41(\mathrm{dd}, J=2.4 \mathrm{~Hz}, 8.8 \mathrm{~Hz}, 1 \mathrm{H}), 2.42(\mathrm{~s}, 3 \mathrm{H}), 1.34(\mathrm{~s}, 9 \mathrm{H}) .{ }^{13} \mathbf{C}$ NMR (100 MHz, CDCl3) $\delta$ 152.7, 148.7, 144.8, 140.5, 135.2, 134.9, 132.9, 130.9, 129.7, 128.6, 127.1, 125.8, 122.3, 115.3, 113.2, 112.9, 108.7, 108.5, 34.8, 31.2, 21.3. ${ }^{\mathbf{1 9}} \mathbf{F}$ NMR (300 MHz, CDCl 3$) \delta$-103.57, HRMS (ESI-TOF) m/z: [M+ H $]^{+}$Calcd for $\mathrm{C}_{26} \mathrm{H}_{25}$ FNS: 402.1686, Found: 402.1689. 


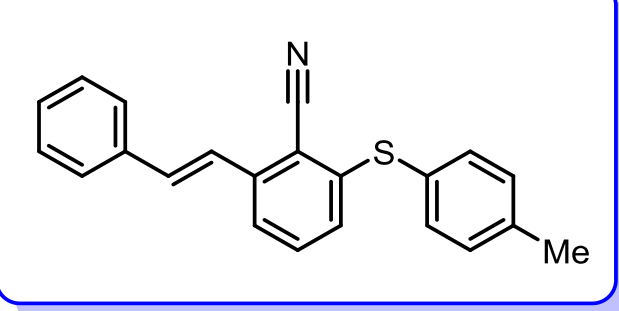

(E)-2-Styryl-6-(p-tolylthio)benzonitrile (4d), ${ }^{1} \mathrm{H}$ NMR (400 MHz, $\left.\mathbf{C D C l}_{3}\right) \boldsymbol{\delta}$ 7.58-7.53 (m, 2H), 7.45$7.28(\mathrm{~m}, 5 \mathrm{H}), 7.34-7.33(\mathrm{~m}, 2 \mathrm{H}), 7.23-7.21(\mathrm{~m}, 4 \mathrm{H}), 6.99$ (d, $J=8.0 \mathrm{~Hz}, 1 \mathrm{H}), 2.39$ (s, 3H). ${ }^{13} \mathbf{C}$ NMR $\left(\mathbf{1 0 0} \mathbf{M H z}, \mathbf{C D C l}_{3}\right) \boldsymbol{\delta} 134.3,133.9,132.3,130.5,128.8,127.1,124.0,122.0,113.5,21.2$. HRMS (ESITOF) m/z: $[\mathrm{M}+\mathrm{H}]^{+}$Calcd for $\mathrm{C}_{22} \mathrm{H}_{18} \mathrm{NS}: 328.1154$, Found: 328.1151 .

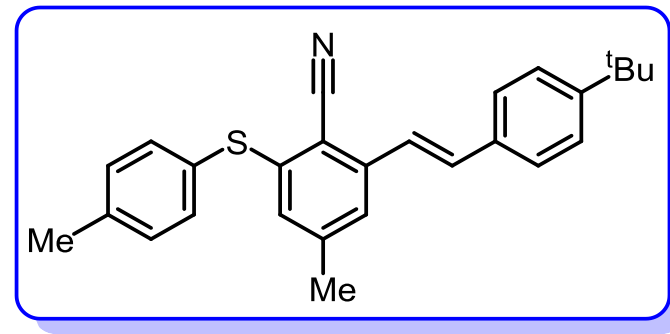

(E)-2-(4-(tert-Butyl)styryl)-4-methyl-6-(p-tolylthio)benzonitrile (4e), ${ }^{1} \mathrm{H}$ NMR $\left(400 \mathrm{MHz}, \mathrm{CDCl}_{3}\right) \delta$ 7.53-7.50 (m, 2H), 7.43-7.38 (m, 6H), 7.24-7.20 (m, 3H), $6.76(\mathrm{~d}, J=2.0 \mathrm{~Hz}, 1 \mathrm{H}), 2.39(\mathrm{~d}, J=3.2 \mathrm{~Hz}$, $3 \mathrm{H}), 2.30(\mathrm{~d}, J=3.2 \mathrm{~Hz}, 3 \mathrm{H}), 1.35(\mathrm{~d}, J=3.6 \mathrm{~Hz}, 9 \mathrm{H}) .{ }^{\mathbf{1 3}} \mathbf{C} \mathbf{N M R}\left(\mathbf{1 0 0} \mathbf{M H z}, \mathbf{C D C l}_{3}\right)$ 143.2, 133.9, 133.4, 130.5, 128.4, 126.9, 125.7, 123.4, 123.2, 108.5, 105.4, 34.7, 31.2 21.9, 21.3. HRMS (ESI-TOF) m/z: [M $+\mathrm{H}]^{+}$Calcd for $\mathrm{C}_{27} \mathrm{H}_{28} \mathrm{NS}$ : 398.1937, Found: 398.1941 .

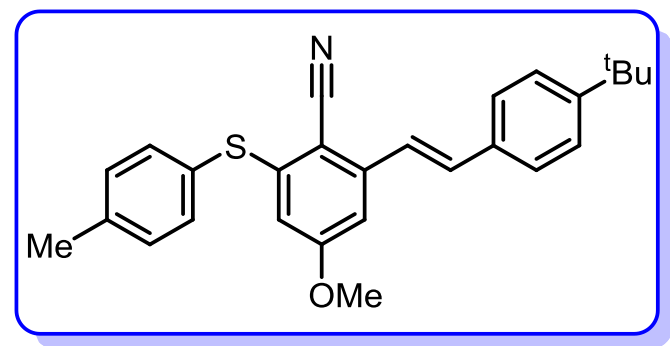

(E)-2-(4-(tert-Butyl)styryl)-4-methoxy-6-(p-tolylthio)benzonitrile (4f), ${ }^{1} \mathrm{H}$ NMR (400 MHz, $\left.\mathrm{CDCl}_{3}\right)$ $\boldsymbol{\delta} 7.51(\mathrm{~d}, J=8.0 \mathrm{~Hz}, 2 \mathrm{H}), 7.42(\mathrm{~d}, J=11.6 \mathrm{~Hz}, 4 \mathrm{H}), 7.38(\mathrm{~d}, J=6.8 \mathrm{~Hz}, 1 \mathrm{H}), 7.22(\mathrm{~d}, J=8.4 \mathrm{~Hz}, 3 \mathrm{H})$, $6.99(\mathrm{dd}, J=1.2 \mathrm{~Hz}, 1 \mathrm{H}), 6.39(\mathrm{dd}, J=1.6 \mathrm{~Hz}, 1 \mathrm{H}), 3.75(\mathrm{~s}, 3 \mathrm{H}), 2.38(\mathrm{~s}, 3 \mathrm{H}), 1.34(\mathrm{~s}, 9 \mathrm{H}) .{ }^{13} \mathbf{C}$ NMR (100 MHz, CDCl3) $\delta$ 162.4, 152.3, 146.1, 143.8, 139.3, 134.5, 133.6, 130.5, 126.9, 125.8, 123.4, 113.4, 107.1， 55.5, 31.2, 29.7 21.3. HRMS (ESI-TOF) $\mathrm{m} / \mathrm{z}:[\mathrm{M}+\mathrm{H}]^{+}$Calcd for C27H28NOS: 414.1886, Found: 414.1883. 


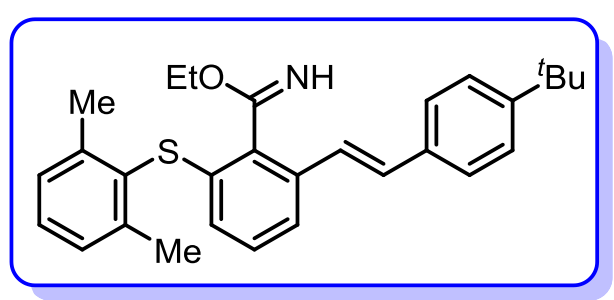

Ethyl (E)-2-(4-(tert-butyl)styryl)-6-((2,6-dimethylphenyl)thio)benzimidate (5a), ${ }^{1} \mathrm{H}$ NMR (400 MHz, CDCl $) \delta$ J 7.43-7.37 (m, 6H), 7.24-7.22 (m, 1H), $7.17(\mathrm{~d}, J=7.6 \mathrm{~Hz}, 2 \mathrm{H}), 7.08(\mathrm{~d}, J=6.8 \mathrm{~Hz}, 2 \mathrm{H}), 6.42$ $(\mathrm{d}, J=7.6 \mathrm{~Hz}, 1 \mathrm{H}), 4.48(\mathrm{dd}, J=6.8 \mathrm{~Hz}, 14.0 \mathrm{~Hz}, 2 \mathrm{H}), 2.41(\mathrm{~s}, 6 \mathrm{H}), 1.47(\mathrm{t}, J=7.2 \mathrm{~Hz}, 3 \mathrm{H}), 1.34$ (s, 9H), ${ }^{13} \mathbf{C}$ NMR (100 MHz, CDCl $) \delta$ 151.3, 143.9, 136.3, 135.4, 134.3, 133.5, 131.2, 130.6, 129.3, 129.3, 128.5, 126.5, 125.6, 124.5, 121.6, 62.1), 34.6, 31.3, 21.8, 14.3. HRMS (ESI-TOF) m/z: [M $+\mathrm{H}]^{+}$Calcd for $\mathrm{C}_{29} \mathrm{H}_{34} \mathrm{NOS}$ : 444.2356, Found: 444.2358 .

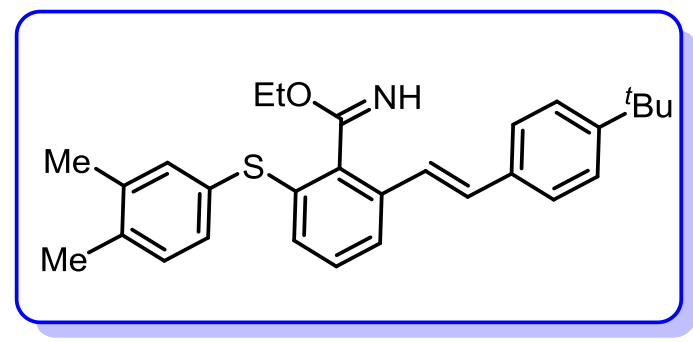

Ethyl (E)-2-(4-(tert-butyl)styryl)-6-((3,4-dimethylphenyl)thio)benzimidate (5b), ${ }^{1} \mathrm{H}$ NMR (400 MHz, $\left.\mathbf{C D C l}_{3}\right) \boldsymbol{\delta} 7.53(\mathrm{~d}, J=7.6 \mathrm{~Hz}, 1 \mathrm{H}), 7.45-7.34(\mathrm{~m}, 5 \mathrm{H}), 7.23-7.19(\mathrm{~m}, 2 \mathrm{H}), 7.16-7.12(\mathrm{~m}, 1 \mathrm{H})$, 7.01-7.07 $(\mathrm{m}, 2 \mathrm{H}), 7.02(\mathrm{~d}, J=8.0 \mathrm{~Hz}, 1 \mathrm{H}), 4.41(\mathrm{q}, J=7.2 \mathrm{~Hz}, 2 \mathrm{H}), 2.25(\mathrm{~s}, 3 \mathrm{H}), 2.23(\mathrm{~s}, 3 \mathrm{H}), 1.40(\mathrm{t}, J=7.2 \mathrm{~Hz}$, 3H), 1.33 (s, 9H), ${ }^{13} \mathbf{C}$ NMR (100 MHz, CDCl $) \delta$ 151.3, 137.8, 136.7, 135.9, 135.5, 134.3, 133.8, 131.2, $130.5,130.3,129.7,129.3,126.5,125.6,124.5,123.2,62.1,34.6,31.2,19.6,19.4,14.2$. HRMS (ESITOF) $\mathrm{m} / \mathrm{z}:[\mathrm{M}+\mathrm{H}]^{+}$Calcd for $\mathrm{C}_{29} \mathrm{H}_{34} \mathrm{NOS}$ : 444.2356, Found: 444.2358.

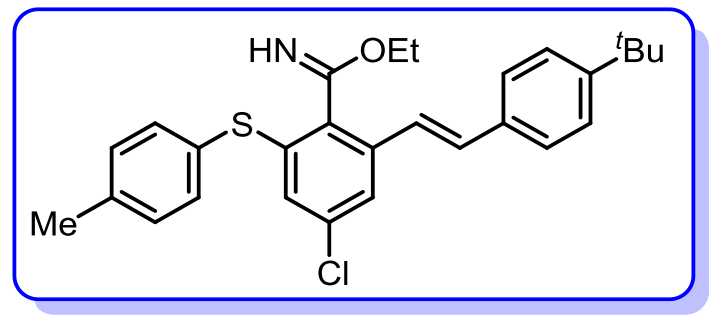

Ethyl (E)-2-(4-(tert-butyl)styryl)-4-chloro-6-(p-tolylthio)benzimidate (5c), ${ }^{1} \mathrm{H}$ NMR (400 MHz, $\left.\mathbf{C D C l}_{3}\right) \boldsymbol{\delta} 7.47(\mathrm{~d}, J=1.6 \mathrm{~Hz}, 1 \mathrm{H}), 7.40(\mathrm{~d}, J=2.0 \mathrm{~Hz}, 3 \mathrm{H}), 7.34(\mathrm{~d}, J=8.0 \mathrm{~Hz}, 2 \mathrm{H}), 7.18(\mathrm{~d}, J=8.0 \mathrm{~Hz}$, 2H), $7.03(\mathrm{dd}, J=16.4 \mathrm{~Hz}, 24.8 \mathrm{~Hz}, 3 \mathrm{H}), 6.88(\mathrm{~d}, J=2.0 \mathrm{~Hz}, 1 \mathrm{H}), 4.40(\mathrm{dd}, J=6.8 \mathrm{~Hz}, 14.0 \mathrm{~Hz}, 2 \mathrm{H})$, $2.37(\mathrm{~s}, 3 \mathrm{H}), 1.40(\mathrm{t}, J=7.2 \mathrm{~Hz}, 3 \mathrm{H}), 1.33(\mathrm{~s}, 9 \mathrm{H}),{ }^{\mathbf{1 3}} \mathbf{C} \mathbf{N M R}\left(\mathbf{1 0 0} \mathbf{M H z}, \mathbf{C D C l}_{3}\right) \delta$ 151.7, 138.8, 138.1, 137.1, 135.4, 133.5, 132.4, 130.4, 129.2, 128.7, 127.8, 126.6, 125.7, 123.2, 122.8, 62.2, 34.7, 31.2, 21.2, 14.2. HRMS (ESI-TOF) m/z: $[\mathrm{M}+\mathrm{H}]^{+}$Calcd for $\mathrm{C}_{28} \mathrm{H}_{31}$ CINOS: 464.1809, Found: 464.1805. 


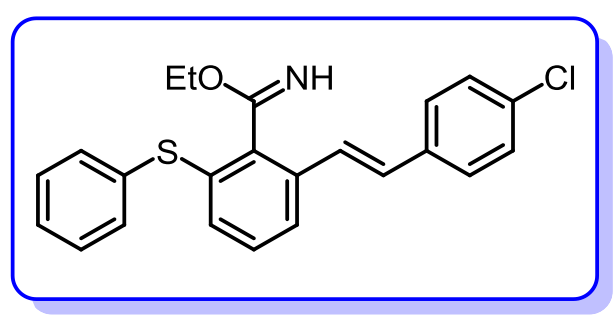

Ethyl (E)-2-(4-chlorostyryl)-6-(phenylthio)benzimidate (5d), ${ }^{1} \mathrm{H}$ NMR (400 MHz, CDCl $) \delta$ 7.687.66 (m, 2H), 7.48-7.41 (m, 2H), 7.37-7.35 (m, 3H), 7.32-7.28 (m, 4H), 7.16-7.07 (m, 1H), 7.16-7.07 (m, $1 \mathrm{H}), 6.99-6.05(\mathrm{~m}, 1 \mathrm{H}), 4.58-4.53(\mathrm{~m}, 2 \mathrm{H}), 2.32(\mathrm{~s}, 3 \mathrm{H}), 1.45-1.42(\mathrm{~m}, 3 \mathrm{H}) .{ }^{\mathbf{1 3}} \mathbf{C}$ NMR (100 MHz, $\left.\mathbf{C D C l}_{3}\right) \boldsymbol{\delta} 158.7,135.6,134.4,133.5,130.3,129.5,128.8,127.9,125.6,124.7,124.3,62.8,20.9,14.5$. HRMS (ESI-TOF) m/z: [M + H] ${ }^{+}$Calcd for $\mathrm{C}_{23} \mathrm{H}_{21}$ ClNOS: 394.1027, Found: 394.1029.

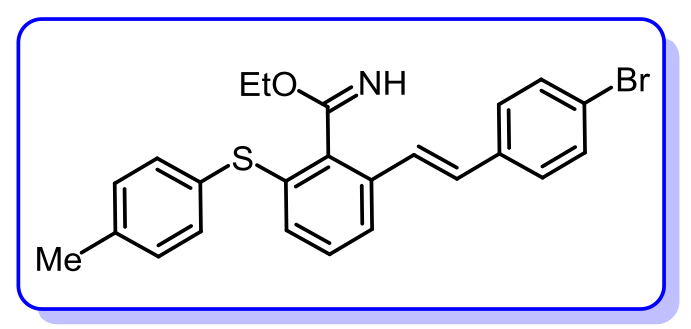

Ethyl (E)-2-(4-bromostyryl)-6-(p-tolylthio)benzimidate (5e), ${ }^{1} \mathrm{H}$ NMR (400 MHz, CDCl $) \delta$ 7.66 (d, $J=8.0 \mathrm{~Hz}, 2 \mathrm{H}), 7.46-7.43(\mathrm{~m}, 5 \mathrm{H}), 7.32-7.28(\mathrm{~m}, 4 \mathrm{H}), 7.07(\mathrm{~d}, J=8.0 \mathrm{~Hz}, 1 \mathrm{H}), 6.98(\mathrm{~d}, J=8.0 \mathrm{~Hz}, 1 \mathrm{H})$, $4.54(\mathrm{dd}, J=7.2 \mathrm{~Hz}, J=14.0 \mathrm{~Hz}, 2 \mathrm{H}), 1.43(\mathrm{t}, J=7.2 \mathrm{~Hz}, 3 \mathrm{H}) .{ }^{13} \mathbf{C}$ NMR (100 MHz, CDCl$) ~ 158.6$, 136.0, 134.4, 131.8, 130.3, 129.8, 129.4, 128.2, 125.7, 124.7, 124.3, 121.7, 62.8, 20.9, 14.4. HRMS (ESITOF) m/z: $[\mathrm{M}+\mathrm{H}]^{+}$Calcd for $\mathrm{C}_{24} \mathrm{H}_{23}$ BrNOS: 452.0678, Found: 452.0681 .

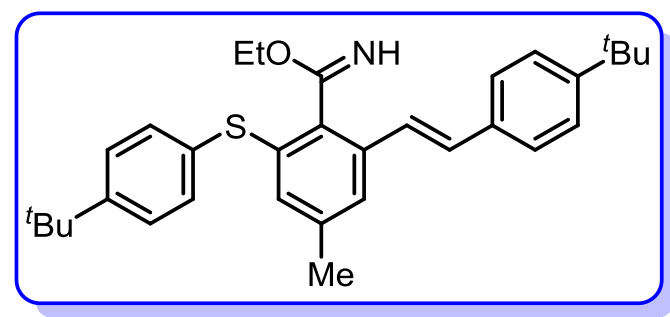

Ethyl (E)-2-((4-(tert-butyl)phenyl)thio)-6-(4-(tert-butyl)styryl)-4-methylbenzimidate (5f), ${ }^{1} \mathrm{H}$ NMR (400 MHz, CDCl 3 ) $\boldsymbol{\delta}$ 7.46-7.43 (m, 2H), 7.40-7.32 (m, 6H), 7.32-7.28 (d, J=8.0 Hz, 1H), 7.28(d, $J=$ $2.4 \mathrm{~Hz}, 1 \mathrm{H}), 7.12(\mathrm{~d}, J=13.6 \mathrm{~Hz}, 1 \mathrm{H}), 7.08(\mathrm{~s}, 1 \mathrm{H}), 6.93(\mathrm{~d}, J=8.0 \mathrm{~Hz}, 1 \mathrm{H}), 4.47-4.43(\mathrm{~m}, 2 \mathrm{H}), 2.32(\mathrm{~s}$, 3H), 1.35-1.34(m, 3H), 1.31-1.28(m, 18H). ${ }^{13} \mathbf{C}$ NMR (100 MHz, CDCl 3$) \boldsymbol{\delta} 158.8,1315,131,5,130.5$, 126.6, 126.0, 125.6, 123.9, 95.2, 62.9, 34.6, 31.3, 21.5, 14.3. HRMS (ESI-TOF) m/z: [M $+\mathrm{H}]^{+}$Calcd for $\mathrm{C}_{32} \mathrm{H}_{40} \mathrm{NOS}$ : 486.2825, Found: 486.2822 . 


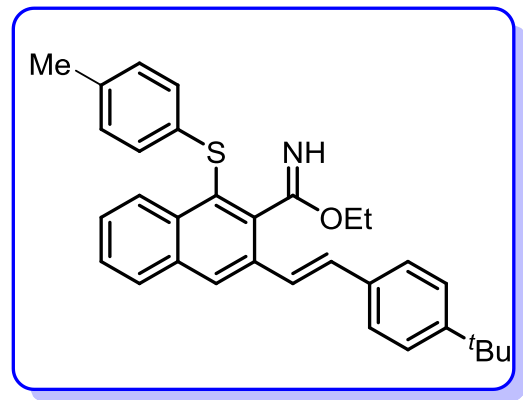

Ethyl (E)-3-(4-(tert-butyl)styryl)-1-(p-tolylthio)-2-naphthimidate (5g), ${ }^{1} \mathrm{H}$ NMR (400 $\left.\mathrm{MHz}, \mathrm{CDCl}_{3}\right)$ $\boldsymbol{\delta} 8.18(\mathrm{~d}, J=13.2 \mathrm{~Hz}, 1 \mathrm{H}), 7.89-7.85(\mathrm{~m}, 3 \mathrm{H}), 7.53-7.48(\mathrm{~m}, 4 \mathrm{H}), 7.42-7.38(\mathrm{~m}, 2 \mathrm{H}), 7.32(\mathrm{~d}, J=8.4 \mathrm{~Hz}$, 2H), 7.21-7.17(m, 1H), $7.12(\mathrm{~d}, J=8.4 \mathrm{~Hz}, 2 \mathrm{H}), 4.54(\mathrm{dd}, J=14.4 \mathrm{~Hz}, 7.2 \mathrm{~Hz}, 2 \mathrm{H}), 2.32(\mathrm{~s}, 3 \mathrm{H}), 1.46(\mathrm{t}, J$ $=7.2 \mathrm{~Hz}, 3 \mathrm{H}), 1.33(\mathrm{~d}, J=6.8 \mathrm{~Hz}, 9 \mathrm{H}) .{ }^{13} \mathbf{C} \mathbf{N M R}\left(\mathbf{1 0 0} \mathbf{M H z}, \mathbf{C D C l}_{3}\right) \boldsymbol{\delta}$ 159.4, 151.0, 141.8, 134.9, 134.0, 132.1, 131.7, 131.1, 129.6, 129.4, 128.1, 127.9, 127.4, 126.5, 125.6, 124.9, 124.8, 124.1, 62.7, 31.2, 29.6, 20.9, 14.4. HRMS (ESI-TOF) m/z: [M + H] ${ }^{+}$Calcd for C32H34NOS: 480.2356, Found: 480.2356.

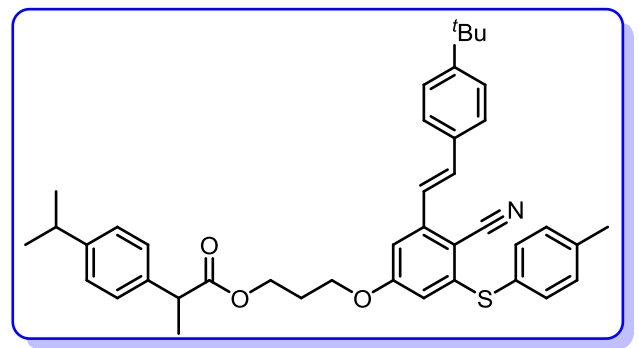

(E)-3-(3-(4-(tert-butyl)styryl)-4-cyano-5-(p-tolylthio)phenoxy)propyl 2-(4-isopropylphenyl) propanoate (4g), ${ }^{1} \mathbf{H}$ NMR (400 MHz, $\left.\mathbf{C D C l}_{3}\right) \boldsymbol{\delta} 8.13(\mathrm{~d}, J=8.4 \mathrm{~Hz}, 1 \mathrm{H}), 7.47-7.42$ (m, 4H), $7.22(\mathrm{~d}, J$ $=4.8 \mathrm{~Hz}, 2 \mathrm{H}), 7.20-7.13(\mathrm{~m}, 6 \mathrm{H}), 7.01(\mathrm{~d}, J=7.6 \mathrm{~Hz}, 2 \mathrm{H}), 6.81-6.79(\mathrm{~m}, 1 \mathrm{H}), 4.68(\mathrm{q}, J=7.2 \mathrm{~Hz}, 2 \mathrm{H})$, 4.32-4.28 (m, 2H), $3.98(\mathrm{t}, J=6.0 \mathrm{~Hz}, 1 \mathrm{H}), 3.70(\mathrm{dd}, J=10.4 \mathrm{~Hz}, 7.2 \mathrm{~Hz}, 1 \mathrm{H}), 2.37(\mathrm{~s}, 3 \mathrm{H}), 2.10-2.04(\mathrm{~m}$, 2H), $1.48(\mathrm{~d}, J=7.2 \mathrm{~Hz}, 3 \mathrm{H}), 1.35(\mathrm{~s}, 9 \mathrm{H}), 0.84(\mathrm{~d}, J=6.8 \mathrm{~Hz}, 6 \mathrm{H}) .{ }^{\mathbf{1 3}} \mathbf{C}$ NMR (100 MHz, CDCl$) ~ 174.7$, 160.6, 151.1, 142.0, 140.5, 137.7), 136.4, 133.4, 130.8, 130.2, 129.3, 127.6, 127.1, 125.4, 121.1, 118.8, 114.6, 104.8, 64.8, 64.5, 61.2, 45.1, 44.9, 34.7), 31.2, 30.1, 29.6, 28.5, 22.3, 21.6, 21.4, 18.3, 14.6. HRMS (ESI-TOF) m/z: $[\mathrm{M}+\mathrm{H}]^{+}$Calcd for $\mathrm{C}_{41} \mathrm{H}_{46} \mathrm{NO} 3 \mathrm{~S}$ : 632.3193, Found: 632.3197.

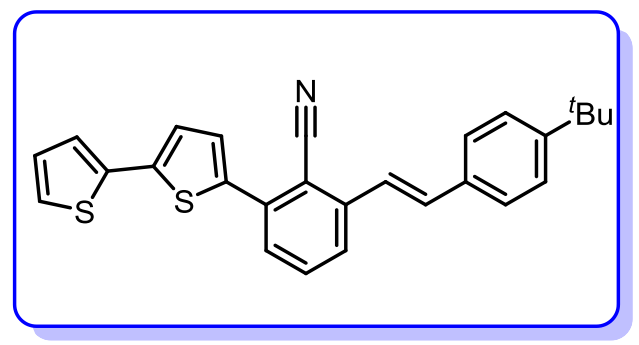

(E)-2-([2,2'-Bithiophen]-5-yl)-6-(4-(tert-butyl)styryl)benzonitrile (7a), ${ }^{1} \mathrm{H}$ NMR (400 MHz, CDCl 3$)$ $\boldsymbol{\delta} 7.76(\mathrm{~d}, J=8.0 \mathrm{~Hz}, 1 \mathrm{H}), 7.64-7.55(\mathrm{~m}, 2 \mathrm{H}), 755-7.49(\mathrm{~m}, 4 \mathrm{H}), 7.44-7.38(\mathrm{~m}, 4 \mathrm{H})$, 7.29-7.24 (m, 2H), 7.23-7.20 (m, 1H), 1.33 (s, 9H). ${ }^{13}$ C NMR (100 MHz, CDCl $)$ 152.0, 140.7, 133.4, 133.3, 133.2, 133.1, 130.0, 132.6, 127.2, 126.8, 125.7, 125.0, 123.2, 118.0, 111.0, 34.7, 31.2. HRMS (ESI-TOF) m/z: [M $+\mathrm{H}]^{+}$Calcd for $\mathrm{C}_{27} \mathrm{H}_{24} \mathrm{NS}_{2}$ : 426.1345, Found: 426.1348 . 


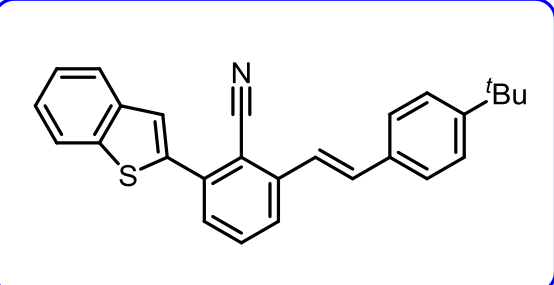

(E)-2-(Benzo[b]thiophen-2-yl)-6-(4-(tert-butyl)styryl)benzonitrile (7b), ${ }^{1} \mathrm{H}$ NMR (400 MHz, CDCl$)$ $\boldsymbol{\delta} 7.78(\mathrm{~d}, J=8.0 \mathrm{~Hz}, 1 \mathrm{H}), 7.64(\mathrm{t}, J=8.0 \mathrm{~Hz}, 2 \mathrm{H}), 7.55-7.50(\mathrm{~m}, 4 \mathrm{H}), 7.46(\mathrm{~s}, 1 \mathrm{H}), 7.43-7.39(\mathrm{~m}, 3 \mathrm{H})$, 7.29-7.26 (m, 2H), 7.24-7.23 (m, 1H), 1.34 (s, 9H). ${ }^{13}$ C NMR (100 MHz, CDCl 3 ) 152.1, 152.0, 141.4, 140.7, 133.2, 133.1, 132.7, 127.3, 126.9, 125.7, 125.1, 123.2, 118.0, 111.1, 34.7, 31.2. HRMS (ESITOF) m/z: $[\mathrm{M}+\mathrm{H}]^{+}$Calcd for C27H24NS: 394.1624, Found: 394.1626.

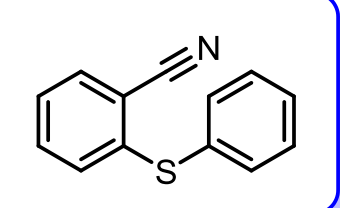

2-(Phenylthio)benzonitrile (8a), ${ }^{1}{ }^{1} \mathbf{H}$ NMR (400 MHz, $\left.\mathbf{C D C l}_{3}\right) \boldsymbol{\delta} 7.40(\mathrm{dd}, J=1.2 \mathrm{~Hz}, 7.6 \mathrm{~Hz}, 1 \mathrm{H})$, 7.49-7.46 (m, 2H), 7.43-7.38 (m, 4H), 7.28-7.25 (m, 1H), 7.13 (dd, $J=0.4 \mathrm{~Hz}, 8.0 \mathrm{~Hz}, 1 \mathrm{H}) .{ }^{13} \mathbf{C}$ NMR $\left(\mathbf{1 0 0} \mathrm{MHz}, \mathbf{C D C l}_{3}\right) \boldsymbol{\delta} 142.3,133.6,133.5,132.9,131.8,129.9,129.7,128.9,126.4,116.9,112.9$.

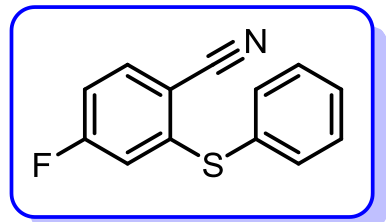

4-Fluoro-2-(phenylthio)benzonitrile (8b), ${ }^{1} \mathbf{H}$ NMR (400 MHz, $\left.\mathbf{C D C l}_{3}\right) \boldsymbol{\delta} 7.62$ (dd, $J=5.2 \mathrm{~Hz}, 8.4 \mathrm{~Hz}$, $1 \mathrm{H}), 7.55-7.53(\mathrm{~m}, 2 \mathrm{H}), 7.48-7.46(\mathrm{~m}, 3 \mathrm{H}), 6.90(\mathrm{td}, J=2.8 \mathrm{~Hz}, 8.0 \mathrm{~Hz}, 1 \mathrm{H}), 6.63(\mathrm{dd}, J=2.4 \mathrm{~Hz}, 9.2$

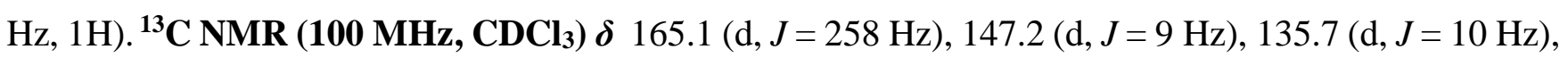
134.8, 130.2, 130.0, 129.8, 116.2, 115.5 (d, $J=26 \mathrm{~Hz}), 113.7$ (d, $J=23 \mathrm{~Hz}), 107.3 .{ }^{19}$ F NMR (300 MHz, CDCl 3 ) $\boldsymbol{\delta}$-101.9. HRMS (ESI-TOF) m/z: [M+ H] ${ }^{+}$Calcd for $\mathrm{C}_{13} \mathrm{H}_{9} \mathrm{FNS}: 230.0434$, Found: 230.0430.

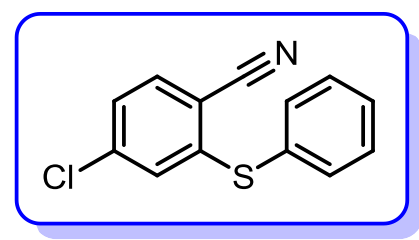

4-Chloro-2-(phenylthio)benzonitrile (8c), ${ }^{1} \mathbf{H}$ NMR (400 MHz, $\left.\mathbf{C D C l}_{3}\right) \delta$ 7.61-7.59 (m, 1H), 7.55-7.51 $(\mathrm{m}, 2 \mathrm{H}), 7.48-7.44(\mathrm{~m}, 3 \mathrm{H}), 7.19(\mathrm{dd}, J=2.0 \mathrm{~Hz}, 8.4 \mathrm{~Hz}, 1 \mathrm{H}), 6.96(\mathrm{~d}, J=2.0 \mathrm{~Hz}, 1 \mathrm{H}) .{ }^{\mathbf{1 3}} \mathbf{C} \mathbf{N M R}(\mathbf{1 0 0}$ MHz, CDCl 3$) \delta$ 145.3, 1398, 134.4, 133.4, 130.1, 129.8, 129.7, 128.5, 126.5, 116.1, 110.0. HRMS (ESITOF) m/z: $[\mathrm{M}+\mathrm{H}]^{+}$Calcd for $\mathrm{C}_{13} \mathrm{H}_{9} \mathrm{ClNS}: 246.0139$, Found: 246.0137. 


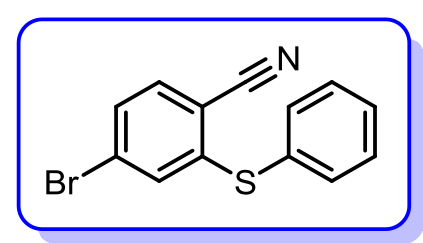

4-Bromo-2-(phenylthio)benzonitrile (8d), ${ }^{2} \mathbf{H}$ NMR (400 MHz, $\left.\mathbf{C D C l}_{3}\right) \delta$ 7.53-7.50 (m, 2H), 7.48-

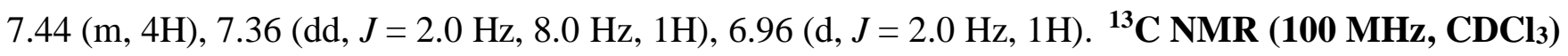
$\delta$ 145.1, 134.4, 134.3, 131.5, 130.1, 129.7, 129.4, 128.2, 127.7, 116.2, 110.6.

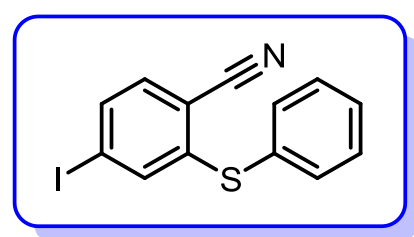

4-Iodo-2-(phenylthio)benzonitrile (8e), ${ }^{1} \mathbf{H}$ NMR (400 MHz, $\left.\mathbf{C D C l}_{3}\right) \boldsymbol{\delta}$ 7.59-7.50 (m, 3H), 7.48-7.44 $(\mathrm{m}, 4 \mathrm{H}), 7.14(\mathrm{~d}, J=1.6 \mathrm{~Hz}, 1 \mathrm{H}) .{ }^{13} \mathbf{C}$ NMR (100 MHz, CDCl 3$) \delta$ 145.2, 134.4, 134.3, 131.5, 130.5, 130.1, 129.7, 129.4, 128.2, 116.2, 110.6. HRMS (ESI-TOF) $\mathrm{m} / \mathrm{z}:[\mathrm{M}+\mathrm{H}]^{+}$Calcd for $\mathrm{C}_{13} \mathrm{H}_{9}$ INS: 337.9495, Found: 337.9498 .

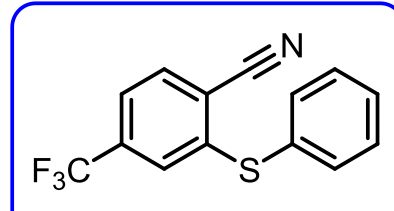

2-(Phenylthio)-4-(trifluoromethyl)benzonitrile (8f), ${ }^{3}$ (eluent: petroleum ether/ethyl acetate $=10: 1$ ), yellow solid, m. p. 81-84 C. ${ }^{1} \mathbf{H}$ NMR (400 MHz, $\left.\mathbf{C D C l}_{3}\right) \boldsymbol{\delta} 7.75(\mathrm{~d}, J=8.0 \mathrm{~Hz}, 1 \mathrm{H}), 7.54-7.52(\mathrm{~m}, 2 \mathrm{H})$, 7.48-7.45 (m, 4H), 7.23 (s, 1H). ${ }^{\mathbf{1 3}} \mathbf{C}$ NMR (100 MHz, CDCl $) \boldsymbol{\delta}$ 145.1, 134.8 (q, $\left.J=34 \mathrm{~Hz}\right), 134.4,134.1$, 130.2, 129.9, 125.3 (q, $J=4.0 \mathrm{~Hz}), 122.6$ (q, $J=4.0 \mathrm{~Hz}), 122.7$ (q, $J=272.0 \mathrm{~Hz}), 121.4,115.7,115.0$. ${ }^{19}$ F NMR (300 MHz, CDCl 3$) \delta$-63.7.

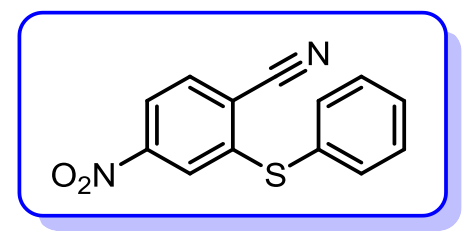

4-Nitro-2-(phenylthio)benzonitrile (8g), ${ }^{\mathbf{1}} \mathbf{H}$ NMR (400 $\left.\mathbf{M H z}, \mathbf{C D C l}_{3}\right) \boldsymbol{\delta} 8.00(\mathrm{dd}, J=2.0 \mathrm{~Hz}, 8.4 \mathrm{~Hz}$, $1 \mathrm{H}), 7.80(\mathrm{~d}, J=8.4 \mathrm{~Hz}, 1 \mathrm{H}), 7.72(\mathrm{~d}, J=2.0 \mathrm{~Hz}, 1 \mathrm{H}), 7.59-7.57(\mathrm{~m}, 2 \mathrm{H}), 7.54-7.51(\mathrm{~m}, 3 \mathrm{H}) .{ }^{13} \mathbf{C}$ NMR $\left(100\right.$ MHz, $\left.\mathbf{C D C l}_{3}\right) \delta$ 150.2, 147.3, 135.0, 134.5, 133.4, 130.5, 128.6, 124.3, 122.2, 120.1, 116.0, 115.1. HRMS (ESI-TOF) m/z: [M + H] $]^{+}$Calcd for $\mathrm{C}_{13} \mathrm{H}_{9} \mathrm{~N}_{2} \mathrm{O}_{2} \mathrm{~S}: 257.0379$, Found: 257.0383. 


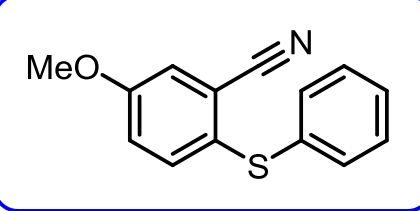

5-Methoxy-2-(phenylthio)benzonitrile (8h), ${ }^{1} \mathbf{H}$ NMR (400 MHz, $\left.\mathbf{C D C l}_{3}\right) \boldsymbol{\delta} 7.38(\mathrm{~d}, J=8.8 \mathrm{~Hz}, 1 \mathrm{H})$, $7.30(\mathrm{~d}, J=4.4 \mathrm{~Hz}, 4 \mathrm{H}), 7.27-7.24(\mathrm{~m}, 1 \mathrm{H}), 7.17(\mathrm{~d}, J=3.2 \mathrm{~Hz}, 1 \mathrm{H}), 7.05(\mathrm{dd}, J=2.8 \mathrm{~Hz}, 8.8 \mathrm{~Hz}, 1 \mathrm{H})$, 3.83 (s, 3H). ${ }^{13} \mathbf{C}$ NMR (100 MHz, CDCl 3$) \delta$ 159.2, 135.4, 135.1, 130.7, 130.2, 129.4, 127.5, 120.0, 118.4, 117.3, 117.0, 55.8. HRMS (ESI-TOF) $\mathrm{m} / \mathrm{z}:[\mathrm{M}+\mathrm{H}]^{+}$Calcd for $\mathrm{C}_{14} \mathrm{H}_{12} \mathrm{NOS}$ : 242.0634, Found: 242.0632.

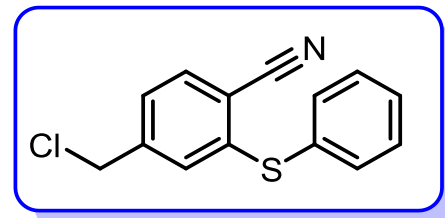

4-(Chloromethyl)-2-(phenylthio)benzonitrile (8i), ${ }^{1} \mathrm{H}$ NMR (400 $\left.\mathbf{M H z}, \mathbf{C D C l}_{3}\right) \delta$ $7.63(\mathrm{~d}, J=8.0 \mathrm{~Hz}$, $1 \mathrm{H}), 7.52-7.48(\mathrm{~m}, 2 \mathrm{H}), 7.43-7.41(\mathrm{~m}, 3 \mathrm{H}), 7.28(\mathrm{dd}, J=1.6 \mathrm{~Hz}, 8.0 \mathrm{~Hz}, 1 \mathrm{H}), 7.10$ (d, $J=1.2 \mathrm{~Hz}, 1 \mathrm{H})$, 4.43 (s, 2H). ${ }^{13} \mathbf{C}$ NMR (100 MHz, CDCl $) \delta$ 143.2, 142.7, 133.9, 133.7, 132.5, 131.1, 129.9, 129.2, 129.1, 126.4, 116.5, 112.3, 44.7. HRMS (ESI-TOF) m/z: $[\mathrm{M}+\mathrm{H}]^{+}$Calcd for $\mathrm{C}_{14} \mathrm{H}_{11} \mathrm{ClNS}$ : 260.0295, Found: 260.0292.

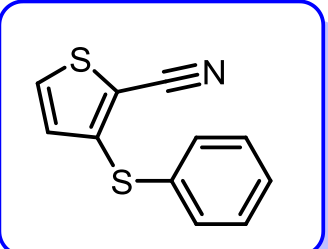

3-(Phenylthio)thiophene-2-carbonitrile (8j), ${ }^{1} \mathbf{H}$ NMR (400 MHz, CDCl $) \boldsymbol{\delta} 7.48(\mathrm{~d}, J=5.2 \mathrm{~Hz}, 1 \mathrm{H})$, 7.46-7.43 (m, 2H), 7.38-7.35 (m, 3H), $6.80(\mathrm{~d}, J=5.2 \mathrm{~Hz}, 1 \mathrm{H}) .{ }^{\mathbf{1 3}} \mathbf{C} \mathbf{N M R}(\mathbf{1 0 0} \mathbf{M H z}, \mathbf{C D C l}) \boldsymbol{\delta}$ 145.1, 132.7, 132.3, 131.9, 129.9, 129.6, 128.6, 113.0, 106.9. HRMS (ESI-TOF) m/z: [M $+\mathrm{H}]^{+}$Calcd for $\mathrm{C}_{11} \mathrm{H}_{8} \mathrm{NS}_{2}: 218.0093$, Found: 218.0090 .

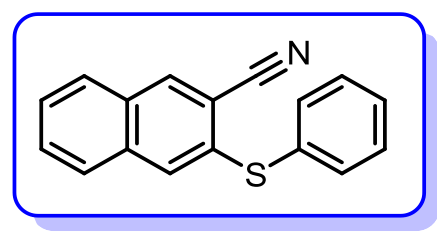

3-(Phenylthio)-2-naphthonitrile (8k), ${ }^{4} \mathbf{H}$ NMR (400 MHz, CDCl $) \boldsymbol{\delta} 8.25$ (s, 1H), 7.85 (d, $J=8.0 \mathrm{~Hz}$, $1 \mathrm{H}), 7.76(\mathrm{~s}, 1 \mathrm{H}), 7.71(\mathrm{~d}, J=8.0 \mathrm{~Hz}, 1 \mathrm{H}), 7.63-7.54(\mathrm{~m}, 2 \mathrm{H}), 7.45(\mathrm{dd}, J=2.4 \mathrm{~Hz}, 8.0 \mathrm{~Hz}, 2 \mathrm{H}), 7.40-$

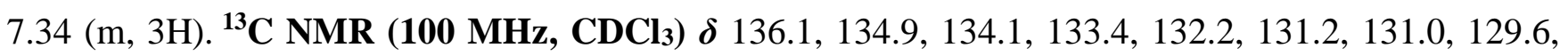
128.2, 128.16, 127.6, 127.5, 117.2, 112.3. 


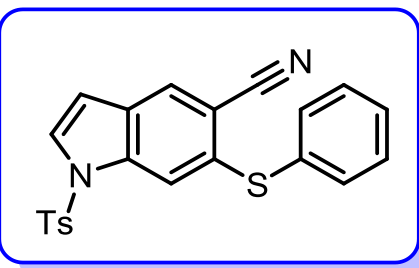

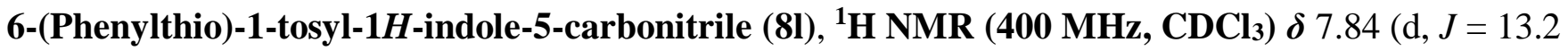
$\mathrm{Hz}, 2 \mathrm{H}), 7.62(\mathrm{~d}, J=3.6 \mathrm{~Hz}, 1 \mathrm{H}), 7.52(\mathrm{~d}, J=8.4 \mathrm{~Hz}, 2 \mathrm{H}), 7.45-7.43(\mathrm{~m}, 5 \mathrm{H}), 7.20(\mathrm{~d}, J=8.4 \mathrm{~Hz}, 2 \mathrm{H})$, $6.64(\mathrm{~d}, J=3.2 \mathrm{~Hz}, 1 \mathrm{H}), 2.38$ (s, 3H). ${ }^{\mathbf{1 3}} \mathbf{C} \mathbf{N M R}\left(\mathbf{1 0 0} \mathbf{M H z}, \mathbf{C D C l}_{3}\right) \boldsymbol{\delta}$ 145.7, 136.6, 136.5, 134.3, 133.0, $130.1,129.7,129.3,128.6,128.5,127.5,127.0,117.4,116.3,109.1,108.1,21.6$. HRMS (ESITOF) m/z: $[\mathrm{M}+\mathrm{H}]^{+}$Calcd for $\mathrm{C}_{22} \mathrm{H}_{17} \mathrm{~N}_{2} \mathrm{O}_{2} \mathrm{~S}_{2}$ : 405.0726, Found: 405.0723.

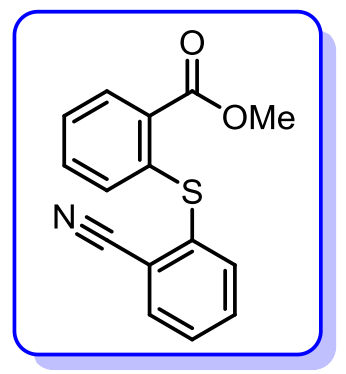

Methyl 2-((2-cyanophenyl)thio)benzoate (8m), ${ }^{1} \mathbf{H}$ NMR (400 MHz, CDCl $) \delta$ $7.98(\mathrm{dd}, J=1.6 \mathrm{~Hz}$, 8.0 Hz, 1H), 7.76-7.74 (m, 1H), 7.60-7.58 (m, 2H), 7.50-7.46 (m, 1H), 7.32-7.28 (m, 1H), $7.21(\mathrm{dt}, J=$ $1.2 \mathrm{~Hz}, 7.6 \mathrm{~Hz}, 1 \mathrm{H}), 6.79(\mathrm{dd}, J=1.2 \mathrm{~Hz}, 8.0 \mathrm{~Hz}, 1 \mathrm{H}), 3.92(\mathrm{~s}, 3 \mathrm{H}) .{ }^{13} \mathbf{C} \mathbf{N M R}\left(\mathbf{1 0 0} \mathbf{M H z}, \mathbf{C D C l}_{3}\right) \boldsymbol{\delta}$ $166.5,139.3,137.8,135.8,134.3,133.4,132.5,131.2,129.0,128.4,125.7,118.1,116.7,52.2$. HRMS (ESI-TOF) m/z: [M + H $]^{+}$Calcd for $\mathrm{C}_{15} \mathrm{H}_{12} \mathrm{NO}_{2} \mathrm{~S}: 270.0583$, Found: 270.0581 .<smiles>Cc1ccc(Sc2ccccc2C#N)cc1</smiles>

2-(p-Tolylthio)benzonitrile (8n), ${ }^{4} \mathbf{H}$ NMR (400 MHz, CDCl3) $\boldsymbol{\delta} 7.60(\mathrm{dd}, J=1.2 \mathrm{~Hz}, 7.6 \mathrm{~Hz}, 1 \mathrm{H})$, 7.41-7.35 (m, 3H), 7.23-7.18 (m, 3H), $7.03(\mathrm{dd}, J=0.8 \mathrm{~Hz}, 8.0 \mathrm{~Hz}, 1 \mathrm{H}), 2.38(\mathrm{~s}, 3 \mathrm{H}) .{ }^{\mathbf{1 3}} \mathbf{C}$ NMR (100 $\left.\mathbf{M H z}_{\mathbf{1}} \mathbf{C D C l}_{3}\right) \boldsymbol{\delta}$ 143.5, 139.6, 134.3, 133.5, 132.9, 130.6, 128.9, 127.6, 125.9, 125.0, 117.0, 111.9, 100.0, 21.3. HRMS (ESI-TOF) m/z: [M + H] $]^{+}$Calcd for $\mathrm{C}_{14} \mathrm{H}_{12} \mathrm{NS}: 226.0685$, Found: 226.0681.

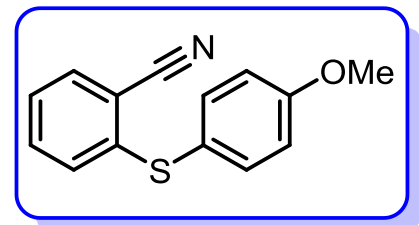

2-((4-Methoxyphenyl)thio)benzonitrile (8o), ${ }^{5}{ }^{1} \mathbf{H}$ NMR (400 $\left.\mathbf{M H z}, \mathbf{C D C l}_{3}\right) \boldsymbol{\delta} 7.59(\mathrm{~d}, J=7.2 \mathrm{~Hz}, 1 \mathrm{H})$, $7.48(\mathrm{~d}, J=8.4 \mathrm{~Hz}, 2 \mathrm{H}), 7.35(\mathrm{td}, J=1.2 \mathrm{~Hz}, 8.0 \mathrm{~Hz}, 1 \mathrm{H}), 7.17(\mathrm{t}, J=7.6 \mathrm{~Hz}, 1 \mathrm{H}), 6.97-6.92(\mathrm{~m}, 3 \mathrm{H})$, 3.85 (s, 3H). ${ }^{\mathbf{1 3}} \mathbf{C} \mathbf{N M R}\left(\mathbf{1 0 0} \mathbf{M H z}, \mathbf{C D C l}_{3}\right) \boldsymbol{\delta} 160.8,144.6,136.8,133.4,132.8,127.8,125.4,120.9,117.0$, $115.4,110.9,55.4$. 


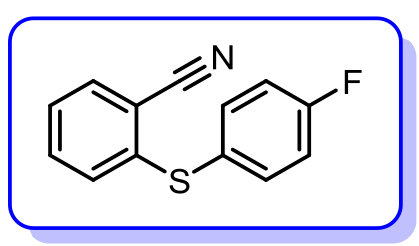

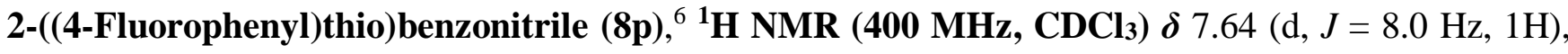
7.52-7.49 (m, 2H), 7.42 (t, $J=8.0 \mathrm{~Hz}, 1 \mathrm{H}), 7.28-7.24(\mathrm{~m}, 1 \mathrm{H}), 7.13-7.07$ (m, 3H). ${ }^{\mathbf{1 3}} \mathbf{C}$ NMR (100 MHz, $\left.\mathbf{C D C l}_{3}\right) \boldsymbol{\delta} 142.6,136.2(\mathrm{~d}, J=8.0 \mathrm{~Hz}), 133.7,133.0,129.3,126.7,126.4,117.1,116.9,116.8,112.5 .{ }^{19} \mathbf{F}$ NMR (300 MHz, CDCl3) $\delta$-111.17.<smiles>N#Cc1ccccc1Sc1ccc(Br)cc1</smiles>

2-((4-Bromophenyl)thio)benzonitrile (8q) ${ }^{6}{ }^{1} \mathbf{H}$ NMR (400 MHz, $\left.\mathbf{C D C l}_{3}\right) \boldsymbol{\delta} 7.66(\mathrm{dd}, J=1.6 \mathrm{~Hz}, 8.0$ $\mathrm{Hz}, 1 \mathrm{H}), 7.53-7.49$ (m, 2H), $7.45(\mathrm{dt}, J=1.2 \mathrm{~Hz}, 8.0 \mathrm{~Hz}, 1 \mathrm{H}), 7.33-7.29$ (m, 3H), 7.21 (dd, $J=0.4 \mathrm{~Hz}$, $4.0 \mathrm{~Hz}, 1 \mathrm{H}) .{ }^{13} \mathbf{C}$ NMR (100 MHz, CDCl$) \boldsymbol{\delta}$ 141.1, 134.5, 133.9, 133.1, 132.9, 131.6, 130.8, 127.1, 123.2, 116.8, 113.8 .

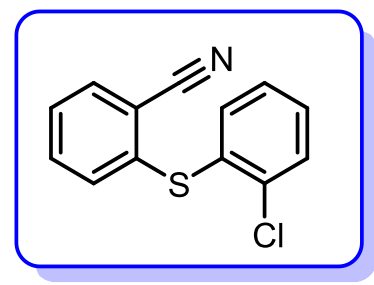

2-((2-Chlorophenyl)thio)benzonitrile (8r), ${ }^{6}{ }^{1} \mathbf{H}$ NMR (400 MHz, $\left.\mathbf{C D C l}_{3}\right) \boldsymbol{\delta} 7.68$ (dd, $J=1.2 \mathrm{~Hz}, 7.6$ $\mathrm{Hz}, 1 \mathrm{H}), 7.49-7.45$ (m, 2H), 7.36-7.28 (m, 3H), 7.25 (dd, $J=1.6 \mathrm{~Hz}, 7.6 \mathrm{~Hz}, 1 \mathrm{H}), 7.22-7.19(\mathrm{~m}, 1 \mathrm{H}) .{ }^{13} \mathbf{C}$ NMR (100 MHz, CDCl 3$) \delta$ 139.5, 136.7, 133.9, 133.1, 131.3, 130.4, 129.8, 127.7, 127.3, 116.7, 114.3.

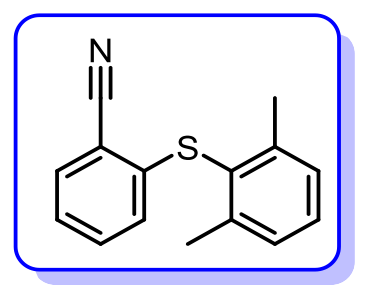

2-((2,6-Dimethylphenyl)thio)benzonitrile (8s), ${ }^{1} \mathbf{H}$ NMR $\left(400 \mathrm{MHz}, \mathbf{C D C l}_{3}\right) \delta$ $7.60(\mathrm{~d}, J=7.6 \mathrm{~Hz}, 1 \mathrm{H})$, 7.31-7.27 (m, 2H), $7.22(\mathrm{~d}, J=7.2 \mathrm{~Hz}, 2 \mathrm{H}), 7.13(\mathrm{t}, J=7.6 \mathrm{~Hz}, 1 \mathrm{H}), 6.52(\mathrm{~d}, J=7.6 \mathrm{~Hz}, 1 \mathrm{H}), 2.41(\mathrm{~s}$, 6H). ${ }^{13} \mathbf{C}$ NMR (100 MHz, CDCl $) \delta$ 144.1, 143.5, 133.5, 132.9, 130.2, 128.8, 128.3, 125.1, 124.6, 116.9, 110.0, 21.7. HRMS (ESI-TOF) m/z: $[\mathrm{M}+\mathrm{H}]^{+}$Calcd for $\mathrm{C}_{15} \mathrm{H}_{14} \mathrm{NS}: 240.0841$, Found: 240.0845 . 


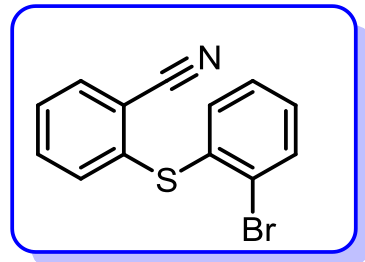

2-((2-Bromophenyl)thio)benzonitrile (8t) ${ }^{6}{ }^{\mathbf{1}} \mathbf{H}$ NMR (400 MHz, $\left.\mathbf{C D C l}_{3}\right) \boldsymbol{\delta} 7.69$ (dd, $J=7.6 \mathrm{~Hz}, 12.8$ $\mathrm{Hz}, 2 \mathrm{H}), 7.48(\mathrm{t}, J=7.2 \mathrm{~Hz}, 1 \mathrm{H}), 7.35(\mathrm{t}, J=7.6 \mathrm{~Hz}, 1 \mathrm{H}), 7.28(\mathrm{~d}, J=4.0 \mathrm{~Hz}, 2 \mathrm{H}), 7.23-7.18(\mathrm{~m}, 2 \mathrm{H})$. ${ }^{13}$ C NMR (100 MHz, CDCl $) \delta$ 139.7, 134.2, 134.0, 133.8, 133.7, 133.2, 131.5, 129.7, 128.3, 127.4, 127.0, 116.7, 114.5.

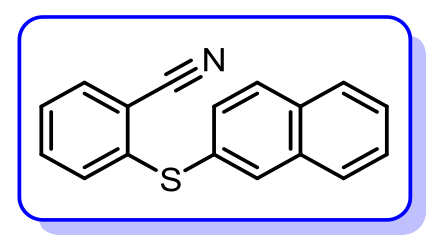

2-(Naphthalen-2-ylthio)benzonitrile (8u) ${ }^{4}{ }^{1} \mathbf{H}$ NMR (400 MHz, $\left.\mathbf{C D C l}_{3}\right) \boldsymbol{\delta} 8.01(\mathrm{~s}, 1 \mathrm{H}), 7.83(\mathrm{~d}, J=8.8$ $\mathrm{Hz}, 2 \mathrm{H}), 7.64(\mathrm{~d}, J=7.6 \mathrm{~Hz}, 1 \mathrm{H}), 7.53-7.51(\mathrm{~m}, 2 \mathrm{H}), 7.45(\mathrm{~d}, J=8.4 \mathrm{~Hz}, 1 \mathrm{H}), 7.23(\mathrm{~d}, J=7.6 \mathrm{~Hz}, 1 \mathrm{H})$, $7.12(\mathrm{~d}, J=8.0 \mathrm{~Hz}, 1 \mathrm{H}), 7.14(\mathrm{~d}, J=8.0 \mathrm{~Hz}, 1 \mathrm{H}) .{ }^{13} \mathbf{C}$ NMR $\left(\mathbf{1 0 0} \mathbf{M H z}, \mathbf{C D C l}_{3}\right) \delta$ 142.4, 133.8, 133.6, 133.3, 133.0, 132.9, 130.0, 129.9, 129.6, 128.9, 127.8, 127.7, 126.9, 126.4, 116.9, 112.7.

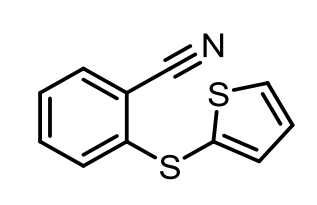

2-(Thiophen-2-ylthio)benzonitrile (8v), ${ }^{6}{ }^{1} \mathbf{H}$ NMR (400 MHz, CDCl 3$) \delta$ 7.61-7.57 (m, 2H), 7.43-7.39 $(\mathrm{m}, 2 \mathrm{H}), 7.22(\mathrm{~d}, J=7.6 \mathrm{~Hz}, 1 \mathrm{H}), 7.14(\mathrm{dd}, J=2.0 \mathrm{~Hz}, 7.6 \mathrm{~Hz}, 1 \mathrm{H}), 7.04(\mathrm{~d}, J=8.4 \mathrm{~Hz}, 1 \mathrm{H}) .{ }^{13} \mathbf{C}$ NMR $\left(\mathbf{1 0 0} \mathrm{MHz}, \mathbf{C D C l}_{3}\right) \delta$ 143.8, 137.7, 133.3, 133.1, 132.8, 128.4, 127.5, 126.0, 116.6, 110.6, 100.0.

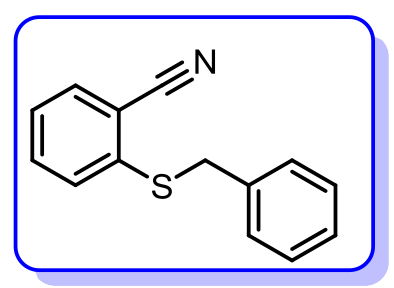

2-(Benzylthio)benzonitrile (8w), ${ }^{6} \mathbf{H}$ NMR (400 MHz, CDCl $) \boldsymbol{\delta} 7.60(\mathrm{dd}, J=1.2 \mathrm{~Hz}, 7.4 \mathrm{~Hz}, 1 \mathrm{H}), 7.43$ $(\mathrm{td}, J=1.6 \mathrm{~Hz}, 8.0 \mathrm{~Hz}, 1 \mathrm{H}), 7.35(\mathrm{~d}, J=7.6 \mathrm{~Hz}, 1 \mathrm{H}), 7.31-7.23(\mathrm{~m}, 6 \mathrm{H}), 4.21(\mathrm{~s}, 2 \mathrm{H}) .{ }^{13} \mathbf{C} \mathbf{N M R}(\mathbf{1 0 0}$ $\left.\mathbf{M H z}, \mathbf{C D C l}_{3}\right) \boldsymbol{\delta} 140.7,135.9,133.6,132.7,130.6,128.8,128.6,127.5,126.6,117.1,114.4,38.7$. 


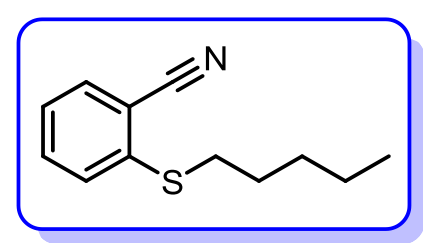

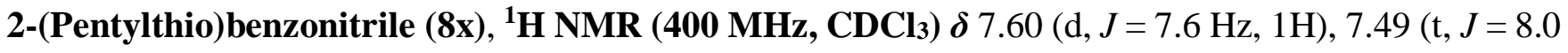
$\mathrm{Hz}, 1 \mathrm{H}), 7.40(\mathrm{~d}, J=8.0 \mathrm{~Hz}, 1 \mathrm{H}), 7.23(\mathrm{t}, J=7.6 \mathrm{~Hz}, 1 \mathrm{H}), 3.01(\mathrm{t}, J=7.2 \mathrm{~Hz}, 2 \mathrm{H}), 1.72-1.65(\mathrm{~m}, 2 \mathrm{H})$, 1.47-1.40 (m, 2H), 1.36-1.31 (m, 2H), $0.90(\mathrm{t}, J=7.2 \mathrm{~Hz}, 3 \mathrm{H}) .{ }^{\mathbf{1 3}} \mathbf{C}$ NMR (100 MHz, CDCl 3$) \boldsymbol{\delta} 142.2$, 133.6, 132.7, 129.1, 128.6, 125.7, 117.2, 113.3, 33.5, 30.9, 28.4, 22.2, 13.9. HRMS (ESI-TOF) m/z: [M $+\mathrm{H}]^{+}$Calcd for $\mathrm{C}_{12} \mathrm{H}_{16} \mathrm{NS}: 206.0998$, Found: 206.0996.

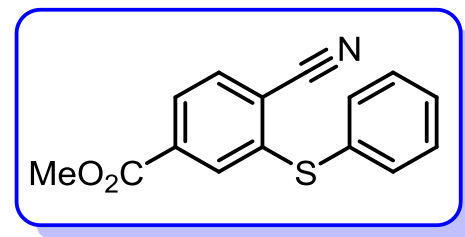

Methyl 4-cyano-3-(phenylthio)benzoate (8y), ${ }^{6} \mathbf{H}$ NMR (400 MHz, CDCl $) \boldsymbol{\delta} 7.87$ (dd, $J=1.2 \mathrm{~Hz}, 8.0$ $\mathrm{Hz}, 1 \mathrm{H}), 7.77$ (d, $J=1.2 \mathrm{~Hz}, 1 \mathrm{H}), 7.70$ (d, $J=8.0 \mathrm{~Hz}, 1 \mathrm{H}), 7.50-7.48$ (m, 2H), 7.50-7.48 (m, 3H), 3.87 $(\mathrm{s}, 3 \mathrm{H}) .{ }^{13} \mathbf{C}$ NMR (100 MHz, CDCl 3$) \delta$ 165.1, 143.2, 134.1, 133.7, 130.9, 130.5, 129.9, 129.3, 127.0, $116.4,116.2,52.7$.

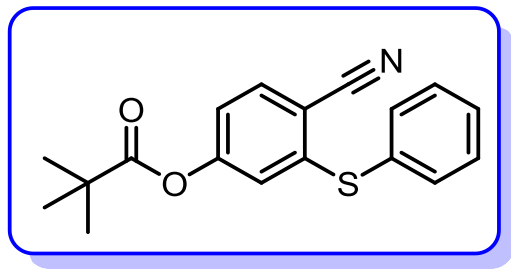

4-Cyano-3-(phenylthio)phenyl pivalate (8z), ${ }^{1} \mathbf{H}$ NMR $\left(400 \mathrm{MHz}, \mathbf{C D C l}_{3}\right) \boldsymbol{\delta} 7.64(\mathrm{~d}, J=8.4 \mathrm{~Hz}, 1 \mathrm{H})$, 7.50-7.48 (m, 2H), 7.43-7.40 (m, 3H), $6.98(\mathrm{dd}, J=2.0 \mathrm{~Hz}, 8.4 \mathrm{~Hz}, 1 \mathrm{H}), 6.81(\mathrm{~d}, J=2.0 \mathrm{~Hz}, 1 \mathrm{H}), 1.28(\mathrm{~s}$, 9H). ${ }^{13} \mathbf{C}$ NMR (100 MHz, CDCl $) \delta$ 176.0, 154.5, 144.3, 134.7, 133.6, 131.2, 129.8, 129.1, 122.9, 120.2, 116.5, 109.8, 39.2, 26.9. HRMS (ESI-TOF) m/z: $[\mathrm{M}+\mathrm{H}]^{+}$Calcd for $\mathrm{C}_{18} \mathrm{H}_{18} \mathrm{NO}_{2} \mathrm{~S}: 312.1053$, Found: 312.1057.

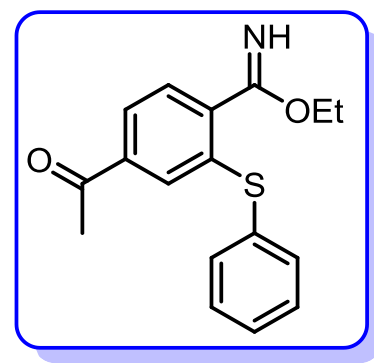

Ethyl 4-acetyl-2-(phenylthio)benzimidate (9j), ${ }^{1} \mathbf{H}$ NMR (400 $\left.\mathbf{M H z}, \mathbf{C D C l}_{3}\right) \boldsymbol{\delta} 7.90(\mathrm{dd}, J=8.0 \mathrm{~Hz}$, $15.6 \mathrm{~Hz}, 1 \mathrm{H}), 7.78(\mathrm{dd}, J=1.2 \mathrm{~Hz}, 8.0 \mathrm{~Hz}, 1 \mathrm{H}), 7.70(\mathrm{~s}, 1 \mathrm{H}), 7.57(\mathrm{~d}, J=8.0 \mathrm{~Hz}, 1 \mathrm{H}), 7.40-7.38(\mathrm{~m}, 2 \mathrm{H})$, 7.36-7.33 (m, 2H), 4.29 (dd, $J=8.4 \mathrm{~Hz}, 15.2 \mathrm{~Hz}, 2 \mathrm{H}), 2.45(\mathrm{~s}, 3 \mathrm{H}), 1.36(\mathrm{t}, J=7.2 \mathrm{~Hz}, 3 \mathrm{H}) .{ }^{13} \mathbf{C}$ NMR 
$\left(\mathbf{1 0 0} \mathbf{M H z}, \mathbf{C D C l}_{3}\right) \delta \boldsymbol{1} 196.8,138.2,133.5,132.6,131.0,129.6,128.8,128.4,128.3,127.1,126.2,62.2$, 26.6, 14.1. HRMS (ESI-TOF) m/z: $[\mathrm{M}+\mathrm{H}]^{+}$Calcd for $\mathrm{C}_{18} \mathrm{H}_{18} \mathrm{NO}_{2} \mathrm{~S}: 312.1053$, Found: 312.1057 .

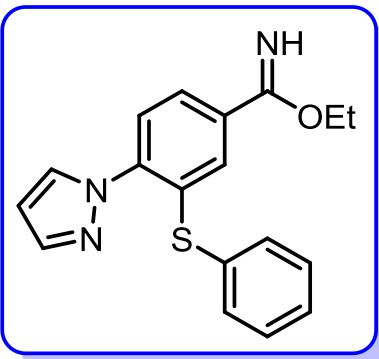

Ethyl 3-(phenylthio)-4-(1H-pyrazol-1-yl)benzimidate (9k), ${ }^{1} \mathbf{H}$ NMR (400 MHz, CDCl $)$ ) 7.89 (dd, $J=2.4 \mathrm{~Hz}, 16.8 \mathrm{~Hz}, 2 \mathrm{H}), 7.76(\mathrm{~d}, J=1.6 \mathrm{~Hz}, 1 \mathrm{H}), 7.57(\mathrm{~d}, J=8.0 \mathrm{~Hz}, 1 \mathrm{H}), 7.35-7.31(\mathrm{~m}, 6 \mathrm{H}), 6.46(\mathrm{t}, J$ $=2.0 \mathrm{~Hz}, 1 \mathrm{H}), 4.31(\mathrm{dd}, J=7.2 \mathrm{~Hz}, 14.4 \mathrm{~Hz}, 2 \mathrm{H}), 1.33(\mathrm{t}, J=7.2 \mathrm{~Hz}, 3 \mathrm{H}) .{ }^{\mathbf{1 3}} \mathbf{C} \mathbf{N M R}\left(\mathbf{1 0 0} \mathbf{M H z}, \mathbf{C D C l}_{3}\right)$ $\boldsymbol{\delta} 1165.3,142.7,141.2,132.9,132.5,130.9,130.2,129.6,128.3,126.1,107.2,61.3,14.2$. HRMS (ESITOF) $\mathrm{m} / \mathrm{z}:[\mathrm{M}+\mathrm{H}]+$ Calcd for $\mathrm{C}_{18} \mathrm{H}_{18} \mathrm{~N}_{3} \mathrm{OS}$ : 324.1165, Found: 324.1167 .

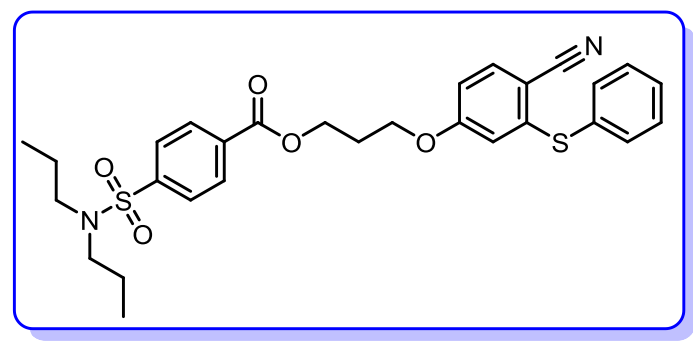

3-(4-Cyano-3-(phenylthio)phenoxy)propyl 4-( $N, N$-dipropylsulfamoyl)benzoate (8za), ${ }^{1}$ H NMR (400 MHz, CDCl 3 ) $\boldsymbol{\delta}$ 8.15-8.10 (m, 2H), 7.88-7.86 (m, 2H), 7.59-7.54 (m, 1H), 7.49-7.46 (m, 2H), 7.41-7.39 $(\mathrm{m}, 2 \mathrm{H}), 6.95(\mathrm{~d}, J=8.8 \mathrm{~Hz}, 1 \mathrm{H}), 6.75(\mathrm{dd}, J=2.4 \mathrm{~Hz}, 8.4 \mathrm{hz}, 1 \mathrm{H}), 6.58(\mathrm{~d}, J=5.6 \mathrm{~Hz}, 1 \mathrm{H}), 4.48(\mathrm{t}, J$ $=6.0 \mathrm{~Hz}, 2 \mathrm{H}), 4.02(\mathrm{~d}, J=6.0 \mathrm{~Hz}, 2 \mathrm{H}), 3.10(\mathrm{t}, J=7.6 \mathrm{~Hz}, 4 \mathrm{H}), 2.24-2.18(\mathrm{~m}, 2 \mathrm{H}), 1.55(\mathrm{dd}, J=7.2 \mathrm{~Hz}$, $6.8 \mathrm{~Hz}, 4 \mathrm{H}), 0.87$ (t, $J=7.2 \mathrm{~Hz}, 6 \mathrm{H}) .{ }^{\mathbf{1 3}} \mathbf{C}$ NMR (100 MHz, CDCl 3$) \boldsymbol{\delta} 165.1,161.9,144.5,144.3,135.2$, 134.0, 133.6, 133.2, 130.1, 129.7, 129.0, 127.0, 119.0, 117.1, 115.7, 115.1, 112.7, 104.8, 64.7, 62.1, 49.9, 28.3, 21.9, 11.1. HRMS (ESI-TOF) m/z: $[\mathrm{M}+\mathrm{H}]^{+}$Calcd for $\mathrm{C}_{29} \mathrm{H}_{33} \mathrm{~N}_{2} \mathrm{O}_{5} \mathrm{~S}_{2}:$ 553.1825, Found: 553.1829.

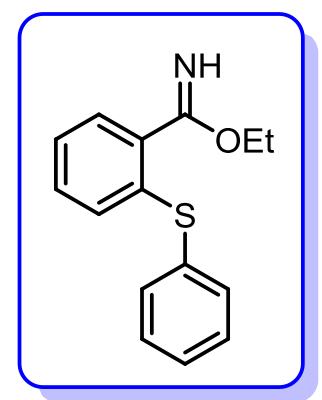

Ethyl 2-(phenylthio)benzimidate (9a), ${ }^{1} \mathbf{H}$ NMR (400 $\left.\mathbf{M H z}, \mathbf{C D C l}_{3}\right) \boldsymbol{\delta} 7.73(\mathrm{~d}, J=3.6 \mathrm{~Hz}, 2 \mathrm{H}), 7.51$ $7.48(\mathrm{~m}, 4 \mathrm{H}), 7.35(\mathrm{t}, J=8.0 \mathrm{~Hz}, 2 \mathrm{H}), 7.14(\mathrm{t}, J=7.2 \mathrm{~Hz}, 1 \mathrm{H}), 4.45(\mathrm{q}, J=6.8 \mathrm{~Hz}, 2 \mathrm{H}), 1.45(\mathrm{t}, J=6.8$ $\mathrm{Hz}, 3 \mathrm{H}) .{ }^{\mathbf{1 3}} \mathbf{C}$ NMR (100 MHz, CDCl 3$) \boldsymbol{\delta} 157.2,137.4,132.5,130.4,128.7,128.3,127.9,127.5,125.5$, 
125.0, 123.2, 62.5, 14.3. HRMS (ESI-TOF) $\mathrm{m} / \mathrm{z}:[\mathrm{M}+\mathrm{H}]^{+}$Calcd for $\mathrm{C}_{15} \mathrm{H}_{16} \mathrm{NOS}$ 258.0947, Found: 258.0943.

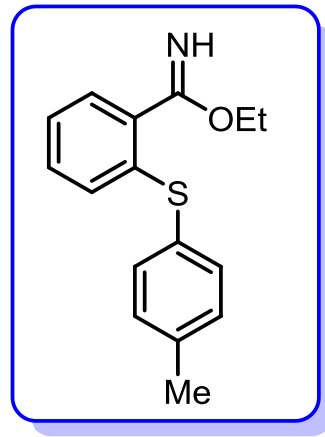

Ethyl 2-(p-tolylthio)benzimidate (9b), ${ }^{1} \mathbf{H}$ NMR (400 MHz, $\left.\mathbf{C D C l}_{3}\right) \delta$ 7.79-7.73 (m, 2H), 7.47-7.37(m, 4H), $7.17(\mathrm{~d}, J=8.0 \mathrm{~Hz}, 2 \mathrm{H}), 4.43(\mathrm{q}, J=6.4 \mathrm{~Hz}, 2 \mathrm{H}), 2.35(\mathrm{~s}, 3 \mathrm{H}), 1.43(\mathrm{t}, \mathrm{J}=6.8 \mathrm{~Hz}, 3 \mathrm{H}) .{ }^{13} \mathbf{C}$ NMR (100 MHz, CDCl3) $\delta$ 156.8, 139.8, 139.5, 135.4, 134.9, 132.5, 129.5, 129.46, 128.3, 127.9, 123.7, 62.4, 21.0, 14.3. HRMS (ESI-TOF) m/z: $[\mathrm{M}+\mathrm{H}]^{+}$Calcd for $\mathrm{C}_{16} \mathrm{H}_{18} \mathrm{NOS}: 272.1104$, Found: 272.1101 .

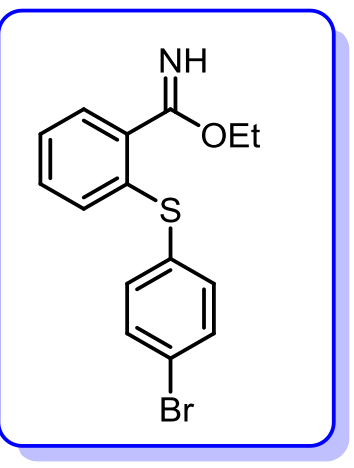

Ethyl 2-((4-bromophenyl)thio)benzimidate (9c), ${ }^{1} \mathbf{H}$ NMR (400 $\left.\mathbf{M H z}, \mathbf{C D C l}_{3}\right) \delta$ $7.70(\mathrm{~d}, J=3.2 \mathrm{~Hz}$, 2H), 7.48-7.42 (m, 5H), 7.35-7.32 (m, 1H), 4.43 (q, $J=6.8 \mathrm{~Hz}, 2 \mathrm{H}), 1.44(\mathrm{t}, J=6.8 \mathrm{~Hz}, 3 \mathrm{H}) .{ }^{13} \mathbf{C}$ NMR $\left(\mathbf{1 0 0} \mathbf{M H z}, \mathbf{C D C l}_{3}\right) \delta \boldsymbol{1} 157.8,139.9,132.2,131.7,130.5,129.4,129.0,128.6,128.4,127.8,124.7,62.6$, 14.3. HRMS (ESI-TOF) m/z: $[\mathrm{M}+\mathrm{H}]^{+}$Calcd for $\mathrm{C}_{15} \mathrm{H}_{15}$ BrNOS: 336.0052, Found: 336.0055 .

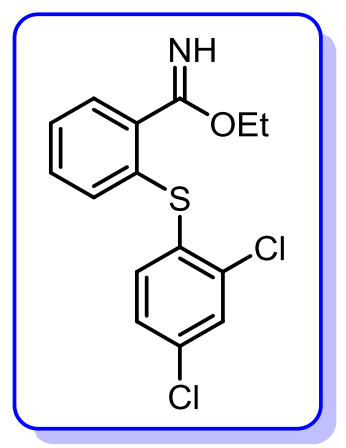

Ethyl 2-((2,4-dichlorophenyl)thio)benzimidate (9d), ${ }^{1} \mathrm{H}$ NMR (400 $\left.\mathbf{M H z}, \mathbf{C D C l}_{3}\right) \delta$ 8.05 (d, $J=8.8$ $\mathrm{Hz}, 1 \mathrm{H}), 7.77-7.75(\mathrm{~m}, 1 \mathrm{H}), 7.59-7.57(\mathrm{~m}, 1 \mathrm{H}), 7.35-7.31(\mathrm{~m}, 4 \mathrm{H}), 4.59(\mathrm{q}, J=6.8 \mathrm{~Hz}, 2 \mathrm{H}), 1.56(\mathrm{t}, J=$ $6.8 \mathrm{~Hz}, 3 \mathrm{H}) .{ }^{\mathbf{1 3}} \mathbf{C} \mathbf{N M R}\left(\mathbf{1 0 0} \mathbf{M H z}, \mathbf{C D C l}_{3}\right) \boldsymbol{\delta} 159.0,157.4,137.9,134.8,131.5,129.9,128.5,128.3,127.8$, 
127.3, 126.8, 63.8, 14.3. HRMS (ESI-TOF) m/z: $[\mathrm{M}+\mathrm{H}]^{+}$Calcd for $\mathrm{C}_{15} \mathrm{H}_{14} \mathrm{Cl}_{2} \mathrm{NOS}$ 326.0168, Found: 326.0163.

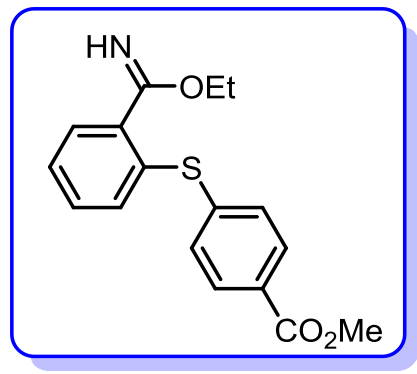

Methyl 4-((2-(ethoxy(imino)methyl)phenyl)thio)benzoate (9e), ${ }^{1} \mathrm{H}$ NMR (400 MHz, CDCl $) \delta 8.59$ $(\mathrm{d}, J=3.6 \mathrm{~Hz}, 1 \mathrm{H}), 8.12(\mathrm{~d}, J=7.6 \mathrm{~Hz}, 1 \mathrm{H}), 7.80(\mathrm{~d}, J=7.6 \mathrm{~Hz}, 2 \mathrm{H}), 7.56(\mathrm{~d}, J=7.2 \mathrm{~Hz}, 1 \mathrm{H}), 7.48-7.39$ $(\mathrm{m}, 2 \mathrm{H}), 7.17(\mathrm{dd}, J=6.8 \mathrm{~Hz}, 5.2 \mathrm{~Hz}, 1 \mathrm{H}), 4.45(\mathrm{q}, J=7.2 \mathrm{~Hz}, 2 \mathrm{H}), 3.88(\mathrm{~s}, 3 \mathrm{H}), 1.46(\mathrm{t}, J=6.8 \mathrm{~Hz}, 1 \mathrm{H})$. ${ }^{13}$ C NMR (100 MHz, CDCl $) \delta$ 166.7, 134.3, 132.6, 130.8, 129.0, 128.4, 127.3, 126.7, 125.8, 118.2, 61.8, 52.3, 14.2. HRMS (ESI-TOF) m/z: $[\mathrm{M}+\mathrm{H}]^{+}$Calcd for $\mathrm{C}_{17} \mathrm{H}_{18} \mathrm{NO}_{3} \mathrm{~S}: 316.1002$, Found: 316.1008 .

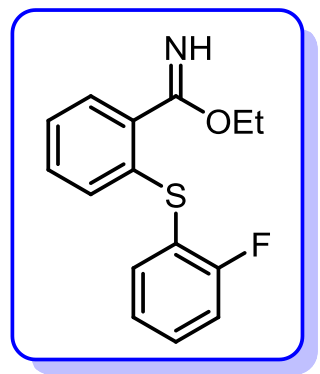

Ethyl 2-((2-fluorophenyl)thio)benzimidate (9f), ${ }^{1} \mathbf{H}$ NMR (400 $\left.\mathbf{M H z}, \mathbf{C D C l}_{3}\right) \boldsymbol{\delta} 7.89$ (t, $J=7.2 \mathrm{~Hz}$, $1 \mathrm{H}), 7.79(\mathrm{~d}, J=3.6 \mathrm{~Hz}, 2 \mathrm{H}), 7.60-7.50(\mathrm{~m}, 3 \mathrm{H}), 7.18(\mathrm{t}, J=6.0 \mathrm{~Hz}, 1 \mathrm{H}), 7.06(\mathrm{t}, J=8.8 \mathrm{~Hz}, 1 \mathrm{H}), 4.49$ $(\mathrm{q}, J=6.8 \mathrm{~Hz}, 2 \mathrm{H}), 1.50(\mathrm{~d}, J=7.2 \mathrm{~Hz}, 3 \mathrm{H}) .{ }^{13} \mathbf{C} \mathbf{N M R}\left(\mathbf{1 0 0} \mathbf{M H z}, \mathbf{C D C l}_{3}\right) \boldsymbol{\delta} 158.3(\mathrm{~d}, J=54.0 \mathrm{~Hz})$, 155.7, 132.2, 130.5, 130.3, 128.4, 128.2, 127.8, 126.9, 126.6, 126.0 (d, J = 7.0 Hz), $125.2,124.5$ (d, $J$ $=3.0 \mathrm{~Hz}), 62.6,14.3 .{ }^{19} \mathbf{F}$ NMR (300 MHz, CDCl $) \quad \delta$-111.17. HRMS (ESI-TOF) m/z: [M $+\mathrm{H}]^{+}$Calcd for $\mathrm{C}_{15} \mathrm{H}_{15}$ FNOS: 276.0853, Found: 276.0851 .

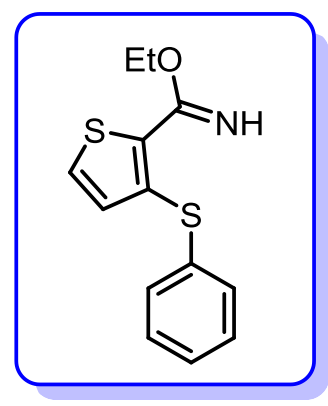

Ethyl 3-(phenylthio)thiophene-2-carbimidate (9g), ${ }^{1} \mathbf{H}$ NMR $\left(400 \mathrm{MHz}, \mathbf{C D C l}_{3}\right) \delta$ $7.96(\mathrm{~d}, J=3.2 \mathrm{~Hz}$, $1 \mathrm{H}), 7.54(\mathrm{~d}, J=7.6 \mathrm{~Hz}, 2 \mathrm{H}), 7.38(\mathrm{t}, J=7.6 \mathrm{~Hz}, 2 \mathrm{H}), 7.20-7.16(\mathrm{~m}, 2 \mathrm{H}), 4.42(\mathrm{q}, J=7.2 \mathrm{~Hz}, 2 \mathrm{H}), 1.45$ $(\mathrm{t}, J=7.2 \mathrm{~Hz}, 3 \mathrm{H}) .{ }^{\mathbf{1 3}} \mathbf{C}$ NMR (100 MHz, $\left.\mathbf{C D C l}_{3}\right) \boldsymbol{\delta}$ 149.8, 140.4, 133.5, 131.3, 129.1, 128.8, 127.5, 125.4, 123.3, 62.4, 14.3. HRMS (ESI-TOF) m/z: $[\mathrm{M}+\mathrm{H}]^{+}$Calcd for $\mathrm{C}_{13} \mathrm{H}_{14} \mathrm{NOS}_{2}$ : 264.0511, Found: 264.0507. 


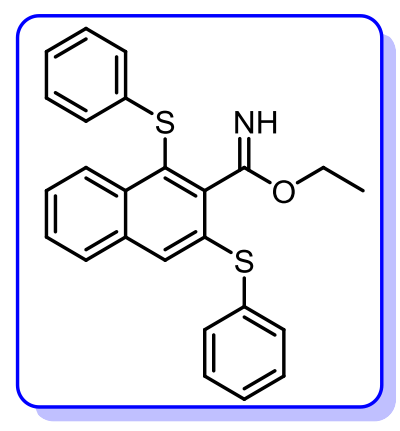

Ethyl 1,3-bis(phenylthio)-2-naphthimidate (9h), ${ }^{1} \mathrm{H}$ NMR (400 MHz, CDCl 3$) \delta 8.27$ (s, 1H), 7.95$7.93(\mathrm{~m}, 5 \mathrm{H}), 7.90-7.49(\mathrm{~m}, 6 \mathrm{H}), 7.37(\mathrm{t}, J=7.6 \mathrm{~Hz}, 2 \mathrm{H}), 7.17-7.16(\mathrm{~m}, 1 \mathrm{H}), 4.51(\mathrm{q}, J=6.8 \mathrm{~Hz}, 2 \mathrm{H})$, $1.49(\mathrm{t}, J=6.8 \mathrm{~Hz}, 3 \mathrm{H}) .{ }^{\mathbf{1 3}} \mathbf{C} \mathbf{N M R}\left(\mathbf{1 0 0} \mathbf{~ M H z}, \mathbf{C D C l}_{3}\right) \boldsymbol{\delta} 157.2,140.6,133.9,132.5,129.8,128.8,128.7$, $128.2, \quad 127.7, \quad 127.4, \quad 126.6, \quad 125.1, \quad 124.5, \quad 123.2, \quad 62.6, \quad 14.4 . \quad$ HRMS (ESI-TOF) m/z: [M $+\mathrm{H}]^{+}$Calcd for $\mathrm{C}_{25} \mathrm{H}_{22} \mathrm{NOS}_{2}$ : 416.1137, Found: 416.1140 .

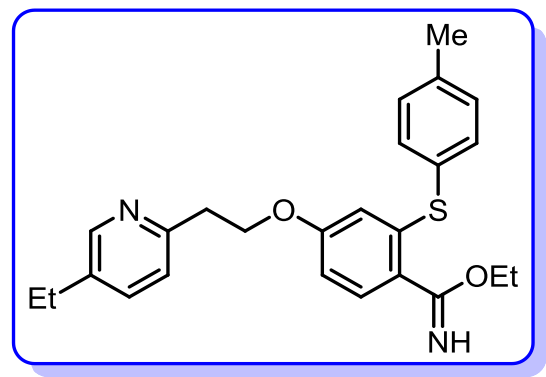

Ethyl 4-(2-(5-ethylpyridin-2-yl)ethoxy)-2-(p-tolylthio)benzimidate (9i), ${ }^{1} \mathrm{H}$ NMR (400 MHz, CDCl 3$)$ $\boldsymbol{\delta} 8.35(\mathrm{~d}, J=1.6 \mathrm{~Hz}, 1 \mathrm{H}), 7.44-7.40(\mathrm{~m}, 2 \mathrm{H}), 7.30(\mathrm{~d}, J=8.0 \mathrm{~Hz}, 2 \mathrm{H}), 7.14(\mathrm{~d}, J=7.6 \mathrm{~Hz}, 2 \mathrm{H}), 7.07$ (d, $J=8.0 \mathrm{~Hz}, 1 \mathrm{H}), 7.30(\mathrm{dd}, J=2.4 \mathrm{~Hz}, 4.4 \mathrm{~Hz}, 1 \mathrm{H}), 6.57(\mathrm{~s}, 1 \mathrm{H}), 4.26(\mathrm{q}, J=6.8 \mathrm{~Hz}, 2 \mathrm{H}), 4.19(\mathrm{t}, J=6.8$ $\mathrm{Hz}, 2 \mathrm{H}), 3.11(\mathrm{t}, J=6.4 \mathrm{~Hz}, 2 \mathrm{H}), 2.61(\mathrm{q}, J=7.6 \mathrm{~Hz}, 2 \mathrm{H}), 2.34(\mathrm{~s}, 3 \mathrm{H}), 1.36(\mathrm{t}, J=6.8 \mathrm{~Hz}, 3 \mathrm{H}), 1.23(\mathrm{t}$, $J=7.6 \mathrm{~Hz}, 3 \mathrm{H}) .{ }^{13} \mathbf{C}$ NMR (100 MHz, CDCl3) $\delta$ 159.9, 155.2, 148.9, 138.3, 137.1, 135.8, 133.3, 131.5, 130.2, 129.9, 123.2, 116.2, 114.1, 112.2, 67.3, 37.2, 25.6, 21.1, 15.3, 14.1. HRMS (ESI-TOF) m/z: [M $+\mathrm{H}]^{+}$Calcd for $\mathrm{C}_{25} \mathrm{H}_{29} \mathrm{~N}_{2} \mathrm{O}_{2} \mathrm{~S}: 421.1944$, Found: 421.1941 .

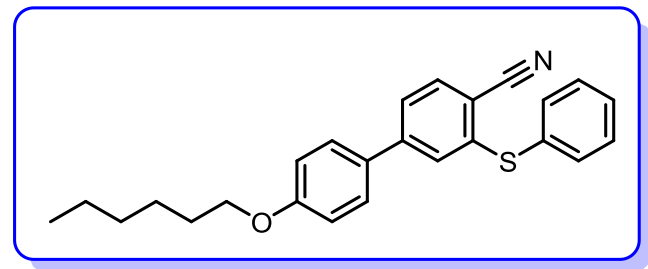

4'-(Hexyloxy)-3-(phenylthio)-[1,1'-biphenyl]-4-carbonitrile (10a), ${ }^{1} \mathrm{H}$ NMR (400 $\left.\mathrm{MHz}, \mathrm{CDCl}_{3}\right) \delta$ $7.67(\mathrm{~d}, J=8.0 \mathrm{~Hz}, 1 \mathrm{H}), 7.54-7.48(\mathrm{~m}, 2 \mathrm{H}), 7.44(\mathrm{dd}, J=1.6 \mathrm{~Hz}, 8.0 \mathrm{~Hz}, 1 \mathrm{H}), 7.41-7.34(\mathrm{~m}, 6 \mathrm{H}), 6.94-$ $6.91(\mathrm{~m}, 2 \mathrm{H}), 3.97(\mathrm{t}, J=6.4 \mathrm{~Hz}, 2 \mathrm{H}), 1.82-1.75(\mathrm{~m}, 2 \mathrm{H}), 1.48-1.42(\mathrm{~m}, 2 \mathrm{H}), 1.35-1.32(\mathrm{~m}, 4 \mathrm{H}), 0.93-$ 0.89 (m, 3H). ${ }^{13} \mathbf{C}$ NMR (100 MHz, CDCl $) \delta$ 159.9, 145.6, 142.0, 134.0, 133.6, 133.0, 132.3, 130.7, $128.7,128.4,128.2,124.9,117.2,115.0,111.1,68.1,31.5,29.1,25.6,22.6,14.0$. HRMS (ESITOF) m/z: $[\mathrm{M}+\mathrm{H}]^{+}$Calcd for $\mathrm{C}_{25} \mathrm{H}_{26} \mathrm{NOS}$ : 388.1730, Found: 388.1736 . 


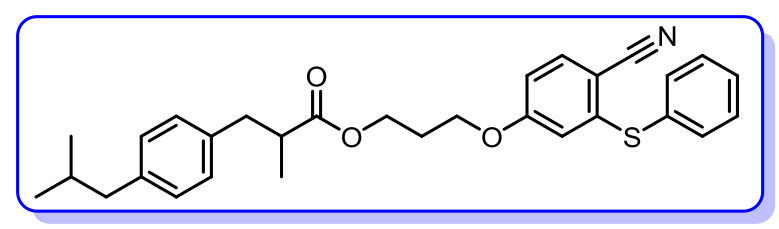

3-(4-Cyano-3-(phenylthio)phenoxy)propyl 3-(4-isobutylphenyl)-2-methylpropanoate $\quad(10 \mathrm{~b}),{ }^{1} \mathbf{H}$ NMR (400 MHz, CDCl$) \boldsymbol{\delta}$ ) 7.53-7.46 (m, 3H), 7.42-7.38 (m, 3H), $7.18(\mathrm{~d}, J=8.0 \mathrm{~Hz}, 2 \mathrm{H}), 7.12$ (dd, $J$ $=8.0 \mathrm{~Hz}, 3 \mathrm{H}), 7.05-7.02(\mathrm{~m}, 1 \mathrm{H}), 4.20-4.14(\mathrm{~m}, 1 \mathrm{H}), 3.76(\mathrm{t}, J=6.4 \mathrm{~Hz}, 2 \mathrm{H}), 3.49(\mathrm{q}, J=7.2 \mathrm{~Hz}, 1 \mathrm{H})$, $2.43(\mathrm{q}, J=7.2 \mathrm{~Hz}, 2 \mathrm{H}), 1.97(\mathrm{t}, J=6.4 \mathrm{~Hz}, 1 \mathrm{H}), 1.87-1.83(\mathrm{~m}, 1 \mathrm{H}), 1.49(\mathrm{~d}, J=7.2 \mathrm{~Hz}, 3 \mathrm{H}), 1.46(\mathrm{~d}, J$ $=7.2 \mathrm{~Hz}, 2 \mathrm{H}), 1.34-1.27(\mathrm{~m}, 2 \mathrm{H}), 0.88(\mathrm{t}, J=7.2 \mathrm{~Hz}, 6 \mathrm{H}) .{ }^{13} \mathbf{C} \mathbf{N M R}\left(\mathbf{1 0 0} \mathbf{M H z}, \mathbf{C D C l}_{3}\right) \delta$ 173.5, 162.0, 146.0, 144.1, 140.5, 144.1, 140.5, 137.6, 133.6, 129.5, 129.2, 127.2, 127.0, 115.9, 112.6, 112.5, 64.5, 60.8, 47.9, 46.8, 45.0, 32.8, 32.7, 30.1, 25.4, 22.3, 18.5. HRMS (ESI-TOF) m/z: [M $+\mathrm{H}]^{+}$Calcd for $\mathrm{C}_{30} \mathrm{H}_{34} \mathrm{NO}_{3} \mathrm{~S}: 488.2254$, Found: 488.2258 .

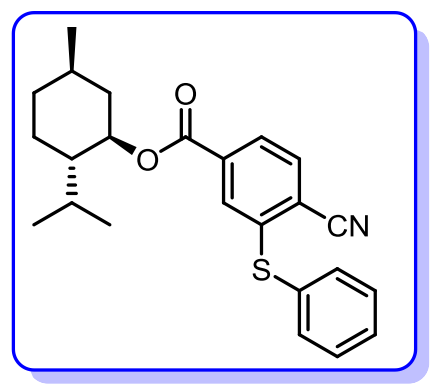

$(1 R, 2 S, 5 R)$-2-Isopropyl-5-methylcyclohexyl 4-cyano-3-(phenylthio)benzoate (10c), ${ }^{1} \mathrm{H}$ NMR (400 MHz, CDCl 3$) \delta 8.10(\mathrm{~s}, 1 \mathrm{H}), 7.86(\mathrm{dd}, J=1.2 \mathrm{~Hz}, 7.6 \mathrm{~Hz}, 1 \mathrm{H}), 7.70$ (s, 1H), 7.53-7.49 (m, 2H), 7.44$7.42(\mathrm{~m}, 3 \mathrm{H}), 4.80(\mathrm{td}, J=4.4 \mathrm{~Hz}, 11.2 \mathrm{~Hz}, 22.0 \mathrm{~Hz}, 1 \mathrm{H}), 2.07-2.04$ (m, 1H), 1.76-1.67 (m, 4H), $1.53-$ $1.47(\mathrm{~m}, 1 \mathrm{H}), 1.43-1.41(\mathrm{~m}, 1 \mathrm{H}), 1.10-0.98(\mathrm{~m}, 2 \mathrm{H}), 0.90(\mathrm{~d}, J=6.8 \mathrm{~Hz}, 3 \mathrm{H}), 0.85(\mathrm{~d}, J=7.2 \mathrm{~Hz}, 3 \mathrm{H})$, $0.70(\mathrm{~d}, J=7.2 \mathrm{~Hz}, 3 \mathrm{H}) .{ }^{13} \mathbf{C}$ NMR (100 MHz, $\left.\mathbf{C D C l}_{3}\right) \boldsymbol{\delta}$ 164.1, 143.5, 134.9, 134.1, 133.6, 130.8, 130.0, 129.9, 129.4, 129.4, 126.9, 116.3, 115.8, 76.1, 47.0, 40.6, 34.1, 31.4, 26.5, 23.6, 22.0, 20.7, 16. HRMS (ESI-TOF) m/z: [M + H] $]^{+}$Calcd for $\mathrm{C}_{24} \mathrm{H}_{28} \mathrm{NO}_{2}$ : 394.1835 , Found: 394.1838 .

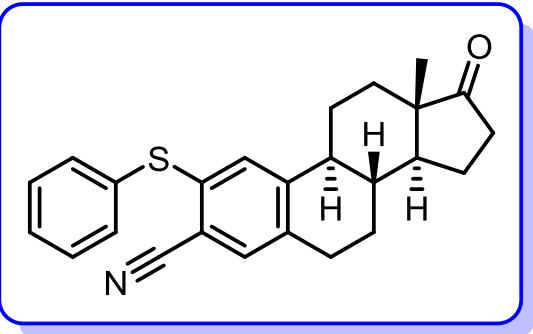

(8R,9S,13S,14S)-13-Methyl-17-oxo-2-(phenylthio)-7,8,9,11,12,13,14,15,16,17-decahydro-6Hcyclopenta[a]phenanthrene-3-carbonitrile (10d), ${ }^{1} \mathbf{H}$ NMR (400 $\left.\mathbf{M H z}, \mathbf{C D C l}_{3}\right) \delta$ 7.81-7.78 (m, 1H), 7.41-7.32 (m, 3H), 7.29 (d, $J=8.0 \mathrm{~Hz}, 1 \mathrm{H}), 7.23-7.20(\mathrm{~m}, 1 \mathrm{H}), 7.13(\mathrm{t}, J=7.2 \mathrm{~Hz}, 1 \mathrm{H}), 4.39-4.32(\mathrm{~m}$, 2H), 2.99-2.94 (m, 2H), 2.55-2.43 (m, 2H), 2.31-2.20 (m, 1H), 2.18-2.13 (m, 1H), 2.06-2.00 (m, 2H), 1.55-1.49 (m, 2H), $1.38(\mathrm{t}, J=7.2 \mathrm{~Hz}, 2 \mathrm{H}), 1.28-1.26(\mathrm{~m}, 1 \mathrm{H}), 0.92(\mathrm{~s}, 3 \mathrm{H}) .{ }^{\mathbf{1 3}} \mathbf{C} \mathbf{N M R}\left(\mathbf{1 0 0} \mathbf{M H z}, \mathbf{C D C l}_{3}\right)$ $\boldsymbol{\delta} 166.7,159.5,145.0,142.6,137.2,136.6,130.1,128.8,128.4,126.8,125.3,123.5,50.4,47.9,44.7,37.8$, 
35.8, 31.5, 29.0, 26.3, 25.6, 21.6, 13.8. HRMS (ESI-TOF) m/z: $[\mathrm{M}+\mathrm{H}]^{+}$Calcd for $\mathrm{C}_{25} \mathrm{H}_{26} \mathrm{NOS}$ 388.1730, Found: 388.1733.

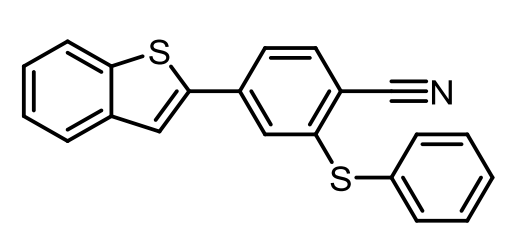

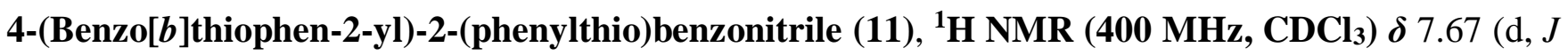
$=8.0 \mathrm{~Hz}, 1 \mathrm{H}), 7.58-7.53(\mathrm{~m}, 4 \mathrm{H}), 7.47-7.43(\mathrm{~m}, 5 \mathrm{H}), 7.37-7.34(\mathrm{~m}, 2 \mathrm{H}), 7.11(\mathrm{~s}, 1 \mathrm{H}) .{ }^{\mathbf{1 3}} \mathbf{C} \mathbf{N M R}(\mathbf{1 0 0}$ MHz, CDCl 3$) \delta$ 145.1, 143.1, 141.2, 140.1, 139.9, 138.9, 134.1, 133.6, 129.9, 129.4, 129.1, 127.3, 125.4, 124.9, 124.2, 123.9, 122.3, 122.0, 116.8. HRMS (ESI-TOF) m/z: $[\mathrm{M}+\mathrm{H}]^{+}$Calcd for $\mathrm{C}_{21} \mathrm{H}_{14} \mathrm{NS}_{2}$ : 344.0562, Found: 344.0567.

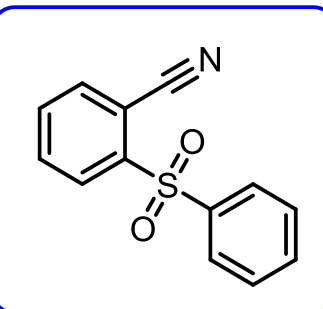

2-(Phenylsulfonyl)benzonitrile (12), ${ }^{1} \mathbf{H}$ NMR (400 MHz, CDCl3) $\boldsymbol{\delta}$ 8.36-8.34 (m, 1H), 8.10-8.08 (m, 2H), 7.82-7.78 (m, 2H), 7.71-7.63 (m, 2H), 7.58-7.54 (m, 2H). ${ }^{13}$ C NMR (100 MHz, d6-DMSO) $\delta$ 143.7, $139.5,135.6,134.2,133.3,133.2,129.8,129.4,128.7,128.5,126.9,115.6,111.4$. HRMS (ESITOF) $\mathrm{m} / \mathrm{z}:[\mathrm{M}+\mathrm{H}]^{+}$Calcd for $\mathrm{C}_{13} \mathrm{H}_{10} \mathrm{NO}_{2} \mathrm{~S}: 244.0427$, Found: 244.0423 .

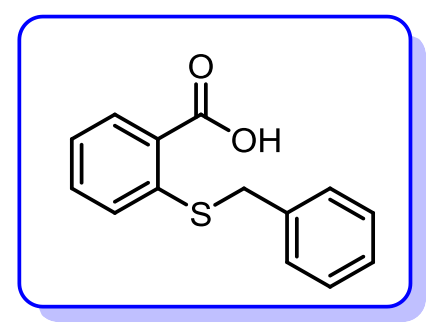

2-(Benzylthio)benzoic acid (13), ${ }^{1}$ H NMR (400 MHz, d6-DMSO) $\delta 8.02$ (d, $\left.J=7.6 \mathrm{~Hz}, 1 \mathrm{H}\right)$, 7.61-7.60 $(\mathrm{m}, 2 \mathrm{H}), 7.55(\mathrm{~d}, J=7.2 \mathrm{~Hz}, 2 \mathrm{H}), 7.45$ (t, $J=7.2 \mathrm{~Hz}, 2 \mathrm{H}), 7.38$ (t, $J=7.2 \mathrm{~Hz}, 1 \mathrm{H}), 7.36-7.30(\mathrm{~m}, 1 \mathrm{H})$, 4.32 (s, 2H). ${ }^{13}$ C NMR (100 MHz, d6-DMSO) $\delta$ 172.7, 146.5, 141.8, 137.6, 136.2, 134.4, 133.7, 132.9, 132.4, 130.9, 129.2, 40.9. HRMS (ESI-TOF) $\mathrm{m} / \mathrm{z}:[\mathrm{M}+\mathrm{H}]^{+}$Calcd for $\mathrm{C}_{14} \mathrm{H}_{13} \mathrm{O}_{2} \mathrm{~S}$ : 245.0631, Found: 245.0634. 


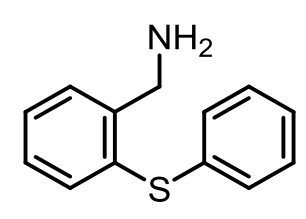

(2-(Phenylthio)phenyl)methanamine (14), ${ }^{1} \mathbf{H}$ NMR (400 MHz, CDCl $)$ $\delta 7.42(\mathrm{~d}, J=7.2 \mathrm{~Hz}, 1 \mathrm{H})$, $7.33(\mathrm{t}, J=6.8 \mathrm{~Hz}, 2 \mathrm{H}), 7.30-7.23(\mathrm{~m}, 3 \mathrm{H}), 7.21-7.20(\mathrm{~m}, 3 \mathrm{H}), 3.95$ (s, 2H). ${ }^{\mathbf{1 3}} \mathbf{C}$ NMR (100 MHz, CDCl$)$ $\delta$ 144.6, 136.2, 133.9, 132.9, 129.6, 129.2, 128.7, 128.5, 127.9, 126.5, 45.0. HRMS (ESI-TOF) m/z: [M $+\mathrm{H}]^{+}$Calcd for C13H14NS: 216.0841, Found: 216.0845.

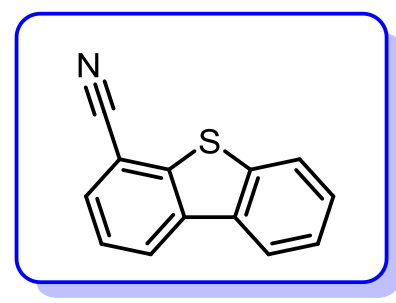

Dibenzo[b,d]thiophene-4-carbonitrile (15), ${ }^{8}{ }^{1} \mathbf{H}$ NMR (400 MHz, CDCl$) \boldsymbol{\delta} 8.30(\mathrm{~d}, J=8.0 \mathrm{~Hz}, 1 \mathrm{H})$, $8.14(\mathrm{dd}, J=1.6 \mathrm{~Hz}, 6.0 \mathrm{~Hz}, 1 \mathrm{H}), 7.90-7.88(\mathrm{~m}, 1 \mathrm{H}), 7.75$ (d, $J=0.8 \mathrm{~Hz}, 7.6 \mathrm{~Hz}, 1 \mathrm{H}), 7.56-7.49$ (m, 3H). ${ }^{13}$ C NMR (100 MHz, CDCl 3$) \delta$ 412.8, 138.9, 136.5, 134.5, 130.9, 127.9, 125.5, 125.1, 124.5, 123.0, 121.9, 117.1, 106.8 .

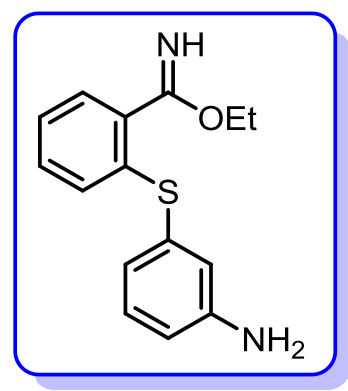

Ethyl 2-((3-aminophenyl)thio)benzimidate (16), ${ }^{1} \mathbf{H}$ NMR (400 $\left.\mathbf{M H z}, \mathbf{C D C l}_{3}\right) \boldsymbol{\delta} 7.24(\mathrm{~d}, J=3.6 \mathrm{~Hz}$, 2H), 7.21-7.16 (m, 2H), $7.03(\mathrm{t}, J=8.0 \mathrm{~Hz}, 1 \mathrm{H}), 6.96(\mathrm{~d}, J=8.0 \mathrm{~Hz}, 1 \mathrm{H}), 6.86(\mathrm{~s}, 1 \mathrm{H}), 6.51(\mathrm{~d}, J=7.6$ $\mathrm{Hz}, 1 \mathrm{H}), 4.37(\mathrm{q}, J=7.2 \mathrm{~Hz}, 2 \mathrm{H}), 1.41(\mathrm{t}, J=7.2 \mathrm{~Hz}, 3 \mathrm{H}) .{ }^{13} \mathbf{C} \mathbf{N M R}\left(\mathbf{1 0 0} \mathbf{M H z}, \mathbf{C D C l}_{3}\right) \boldsymbol{\delta} 159.3,149.3$, 137.6, 131.3, 129.9, 129.3, 129.2, 128.0, 121.6, 120.7, 120.6, 62.5, 29.7, 14.3. HRMS (ESI-TOF) m/z: [M $+\mathrm{H}]^{+}$Calcd for $\mathrm{C}_{15} \mathrm{H}_{17} \mathrm{~N}_{2} \mathrm{OS}: 273.1056$, Found: 273.1053 .

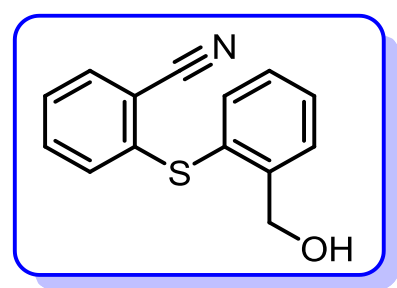

2-((2-(Hydroxymethyl)phenyl)thio)benzonitrile (17), ${ }^{1} \mathbf{H}$ NMR (400 MHz, CDCl $) \delta$ $7.61(\mathrm{~d}, J=7.6$ $\mathrm{Hz}, 2 \mathrm{H}), 7.46-7.36(\mathrm{~m}, 3 \mathrm{H}), 7.33-7.29(\mathrm{~m}, 1 \mathrm{H}), 7.25-7.22(\mathrm{~m}, 1 \mathrm{H}), 6.96(\mathrm{~d}, J=8.0 \mathrm{~Hz}, 1 \mathrm{H}), 4.80(\mathrm{~s}, 2 \mathrm{H})$. 
${ }^{13}$ C NMR (100 MHz, CDCl $)$ \& 143.9, 142.0, 135.3, 133.7, 133.1, 129.9, 129.0, 128.7, 128.7, 126.3, 116.8, 112.3, 63.0. HRMS (ESI-TOF) m/z: $[\mathrm{M}+\mathrm{H}]^{+}$Calcd for $\mathrm{C}_{14} \mathrm{H}_{14} \mathrm{NOS}: 216.0841$, Found: 216.0845 .

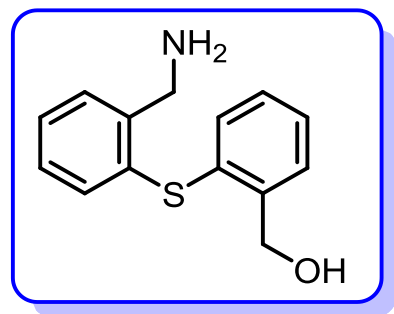

(2-((2-(Aminomethyl)phenyl)thio)phenyl)methanol (18), ${ }^{1} \mathrm{H}$ NMR (400 $\left.\mathrm{MHz}, \mathrm{CDCl}_{3}\right) \delta 7.41(\mathrm{~d}, J=$ $7.2 \mathrm{~Hz}, 1 \mathrm{H}), 7.21$ (d, $J=7.2 \mathrm{~Hz}, 1 \mathrm{H}), 7.18-7.11(\mathrm{~m}, 2 \mathrm{H}), 7.08-7.00(\mathrm{~m}, 4 \mathrm{H}), 4.61(\mathrm{~s}, 2 \mathrm{H}), 3.77(\mathrm{~s}, 2 \mathrm{H})$. ${ }^{13}$ C NMR (100 MHz, CDCl $)$ \& 142.7, 141.8, 133.5, 132.7, 132.1, 131.8, 128.7, 128.2, 128.0, 127.9, 127.7, 127.6, 62.3, 44.5. HRMS (ESI-TOF) m/z: $[\mathrm{M}+\mathrm{H}]^{+}$Calcd for $\mathrm{C}_{14} \mathrm{H}_{16} \mathrm{NOS}: 246.0947$, Found: 246.0943 .

\section{F. References:}

1) Fernndez-Rodrguez, M. A.; Shen, Q.; Hartwig, J. F. Chem. Eur. J. 2006, 12, 7782-7796.

2) Wei, X.; Chen, Y.; Duan, R.; Liu, J.; Wang, R.; Liu, Y.; Li, Z.; Yi, Y.; Yamada-Takamura, Y.; Wangac, P.; Wang, Y. J. Mater. Chem. C. 2017, 5, 12077-12084.

3) Ann, J.; Jung, A.; Kim, M.-Y.; Kim, H.-M.; Ryu, H. C. Kim, S.; Kang, D. W.; Hong, S. Cui, M.; Choi, S.; Blumberg, P. M.; Frank-Foltyn, R.; Bahrenberg, G.; Stockhausen, H.; Christoph, T.; Lee, J. Bioorg. Med. Chem. 2015, 23, 6844-6854.

4) Pawliczek, M.; Garve, L. B.; Werz, D. Org. Lett. 2015, 17, 1716-719.

5) Arisawa, M.; Suzuki, T.; Ishikawa, T.; Yamaguchi, M. J. Am. Chem. Soc. 2008, 130, 12214-12215.

6) Zhou, Y.; Wang, Y.; Loub, Y.; Song, Q. Chem. Commun. 2019, 55, 10265-10268.

7) Pawliczek, M.; Garve, L. B.; Werz, D. Org. Lett. 2015, 17, 1716-719.

8) Liu, L.-Y.; Yeung, K.-S. Yu, J.-Q. Chem. Eur. J., 2019, 25, 2199-2202. 


\section{G. NMR Spectrum}

(E)-2-(4-(tert-Butyl)styryl)-6-(p-tolylthio)benzonitrile (4a)
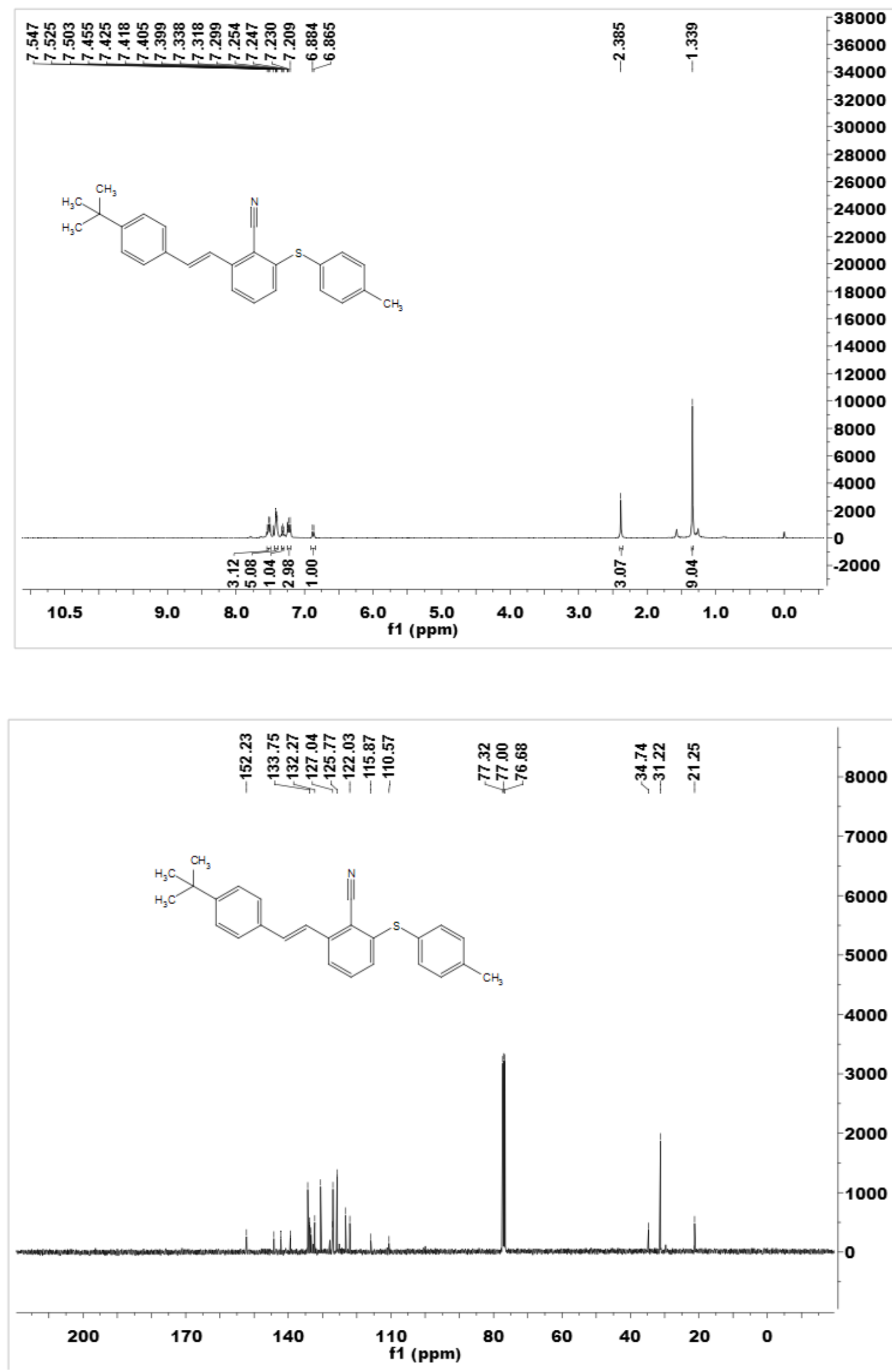
(E)-2-(4-(tert-Butyl)styryl)-6-((4-isopropylphenyl)thio)benzonitrile (4b)
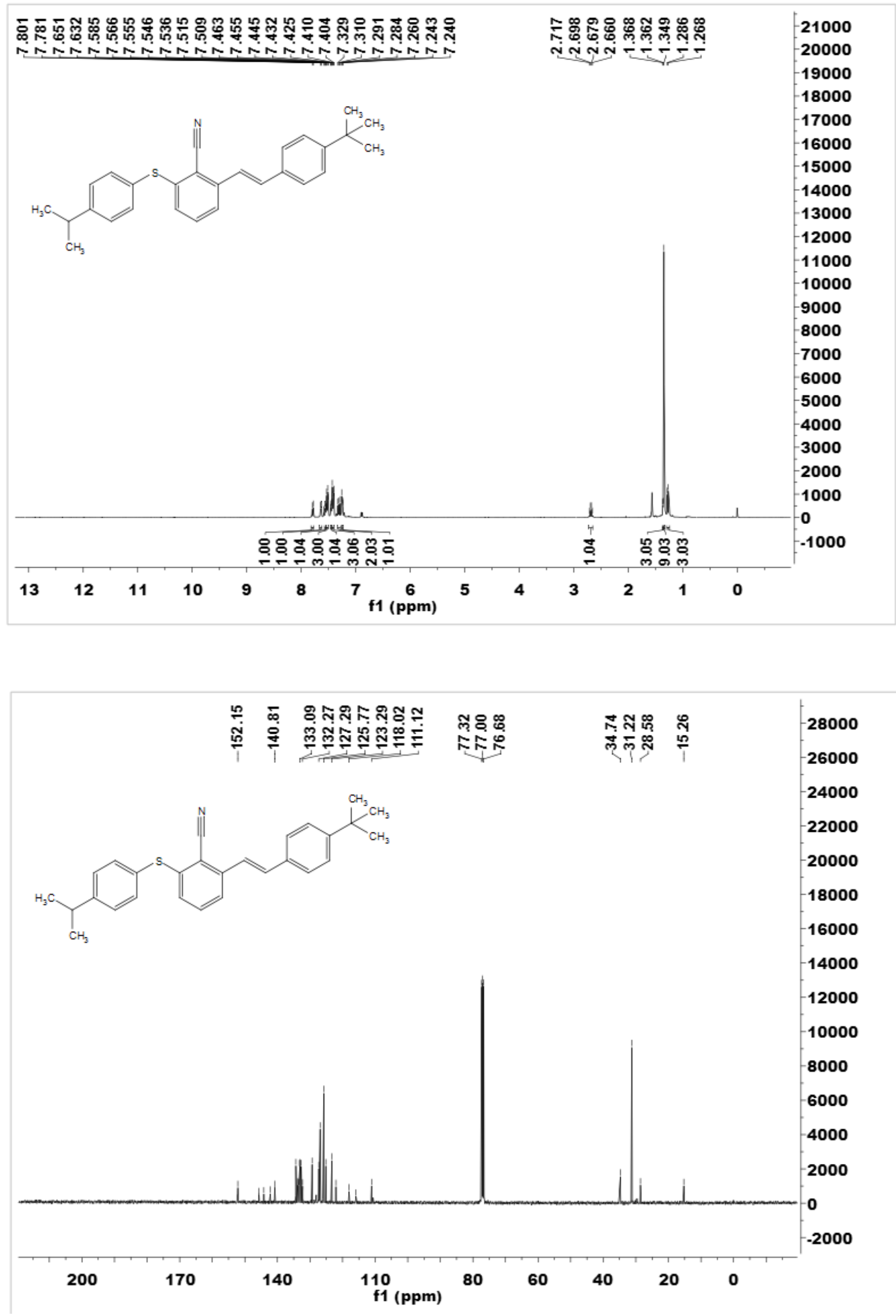
(E)-2-(4-(tert-Butyl)styryl)-4-fluoro-6-(p-tolylthio)benzonitrile (4c)
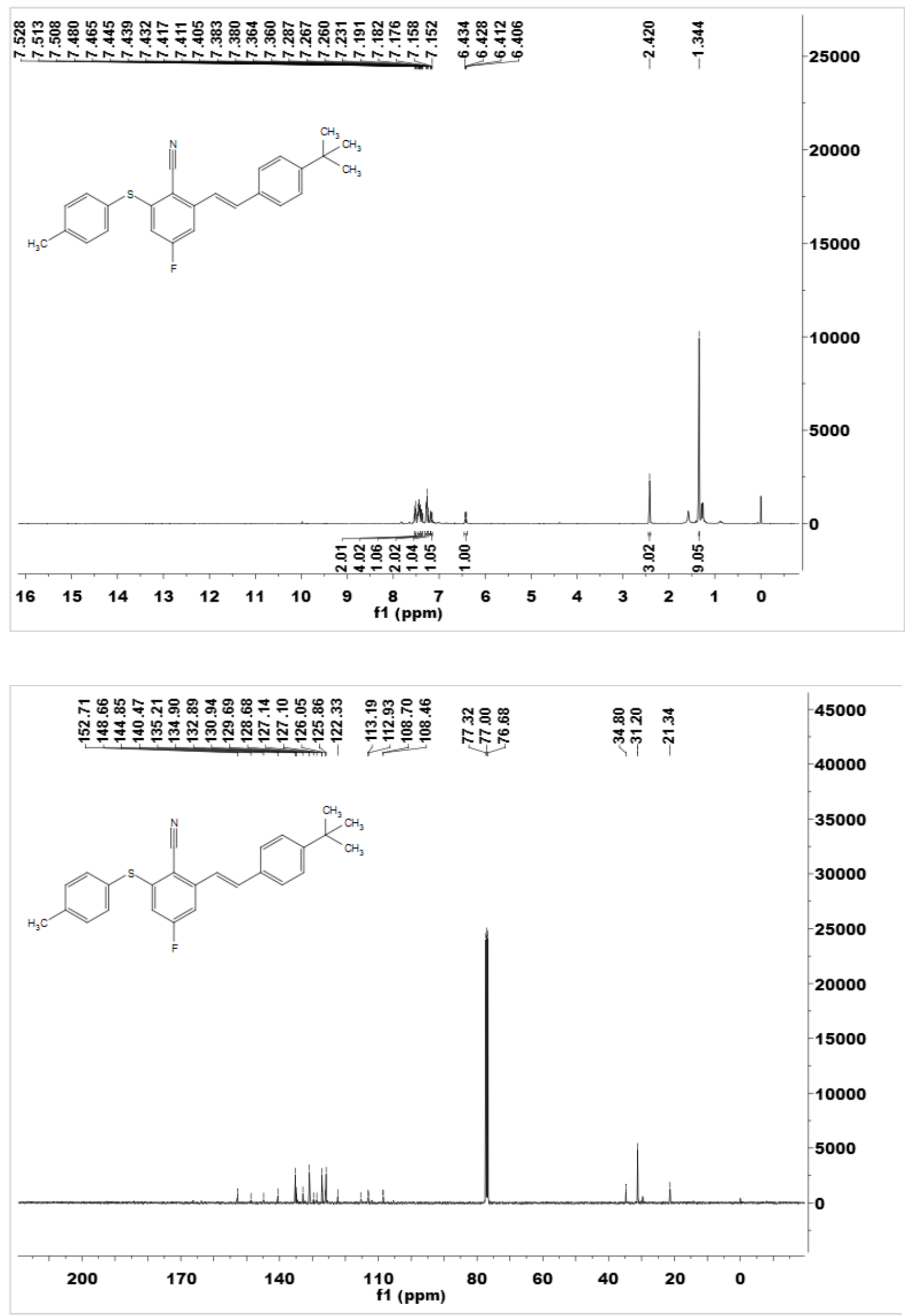


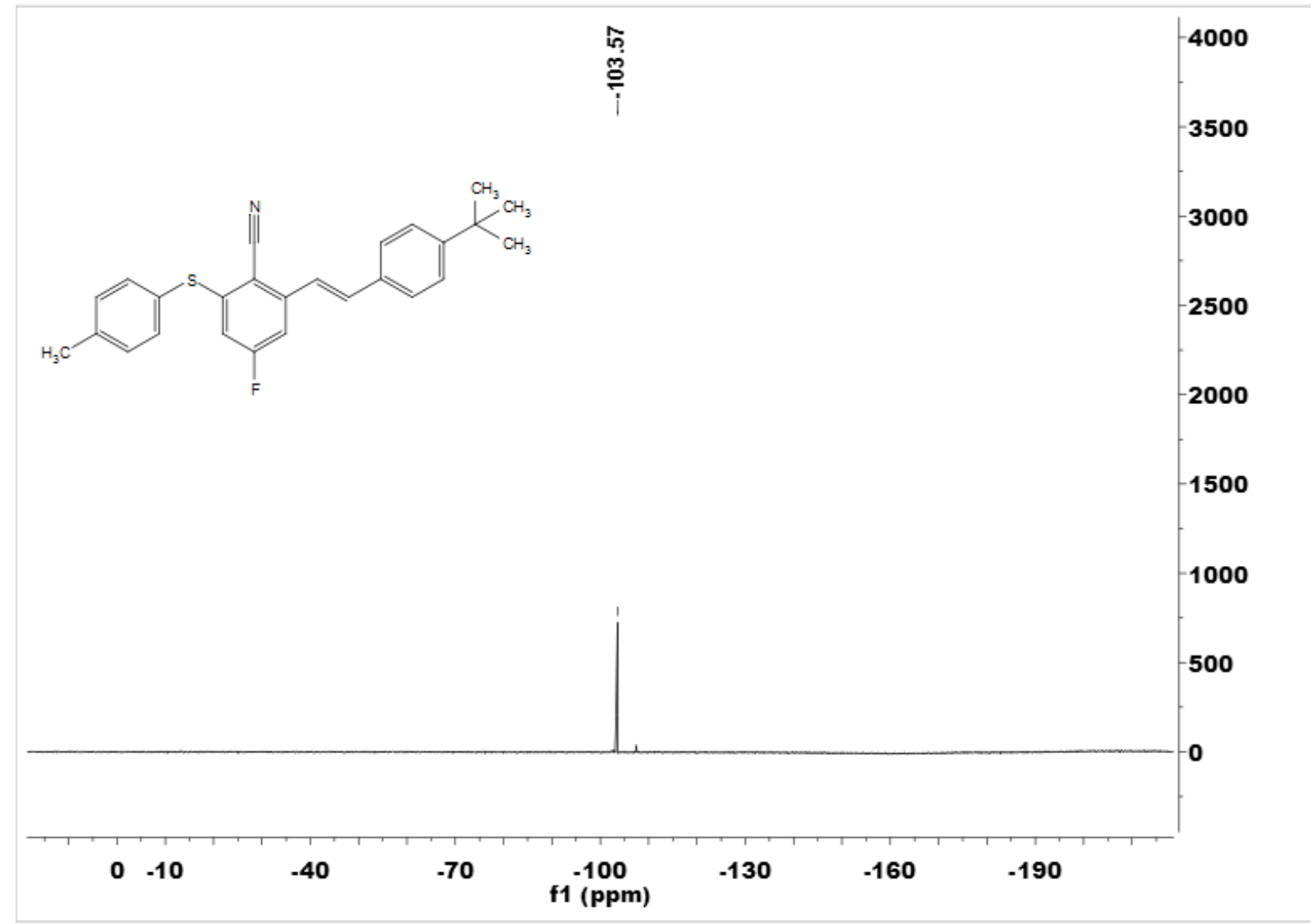

(E)-2-Styryl-6-(p-tolylthio)benzonitrile (4d)

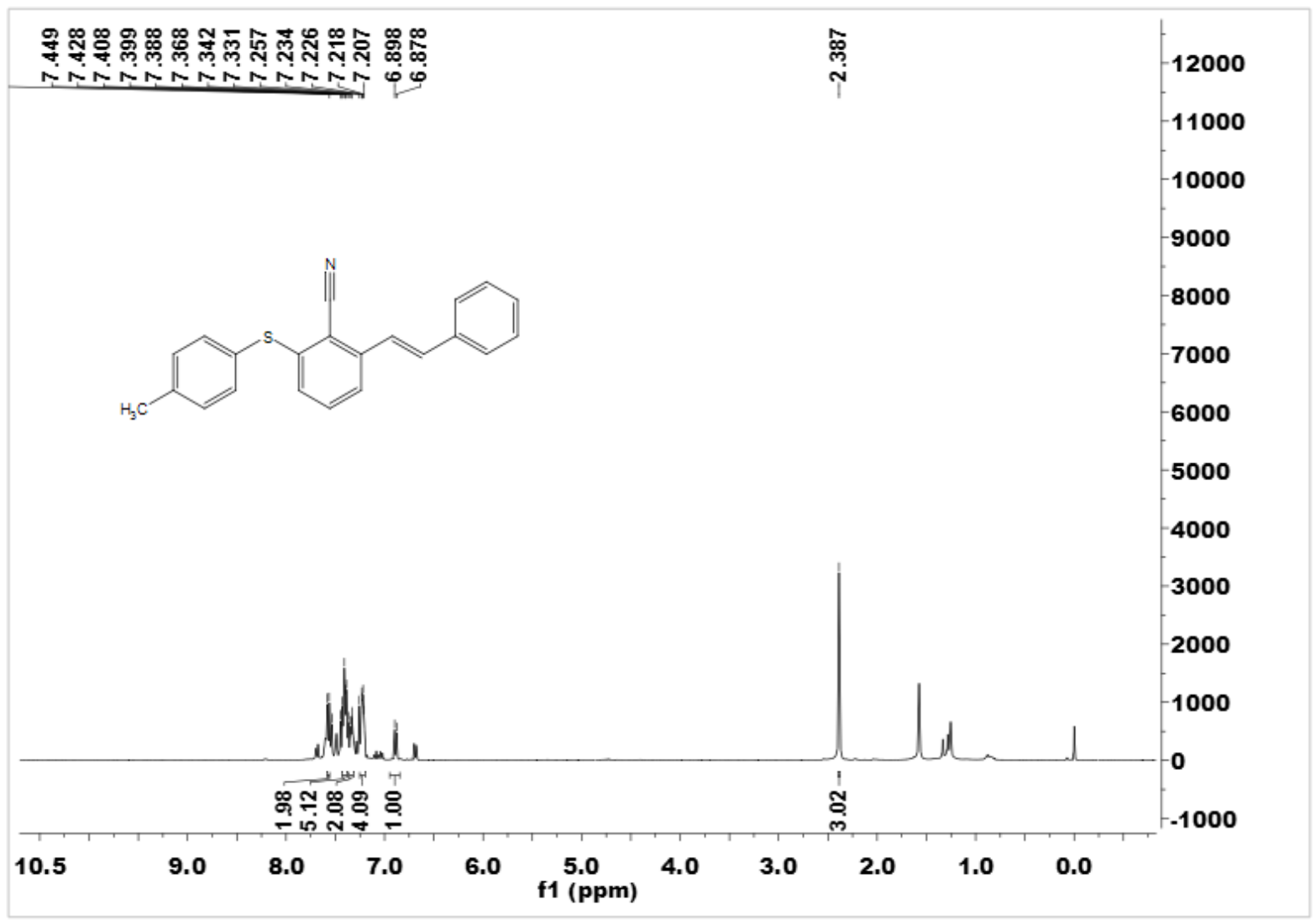




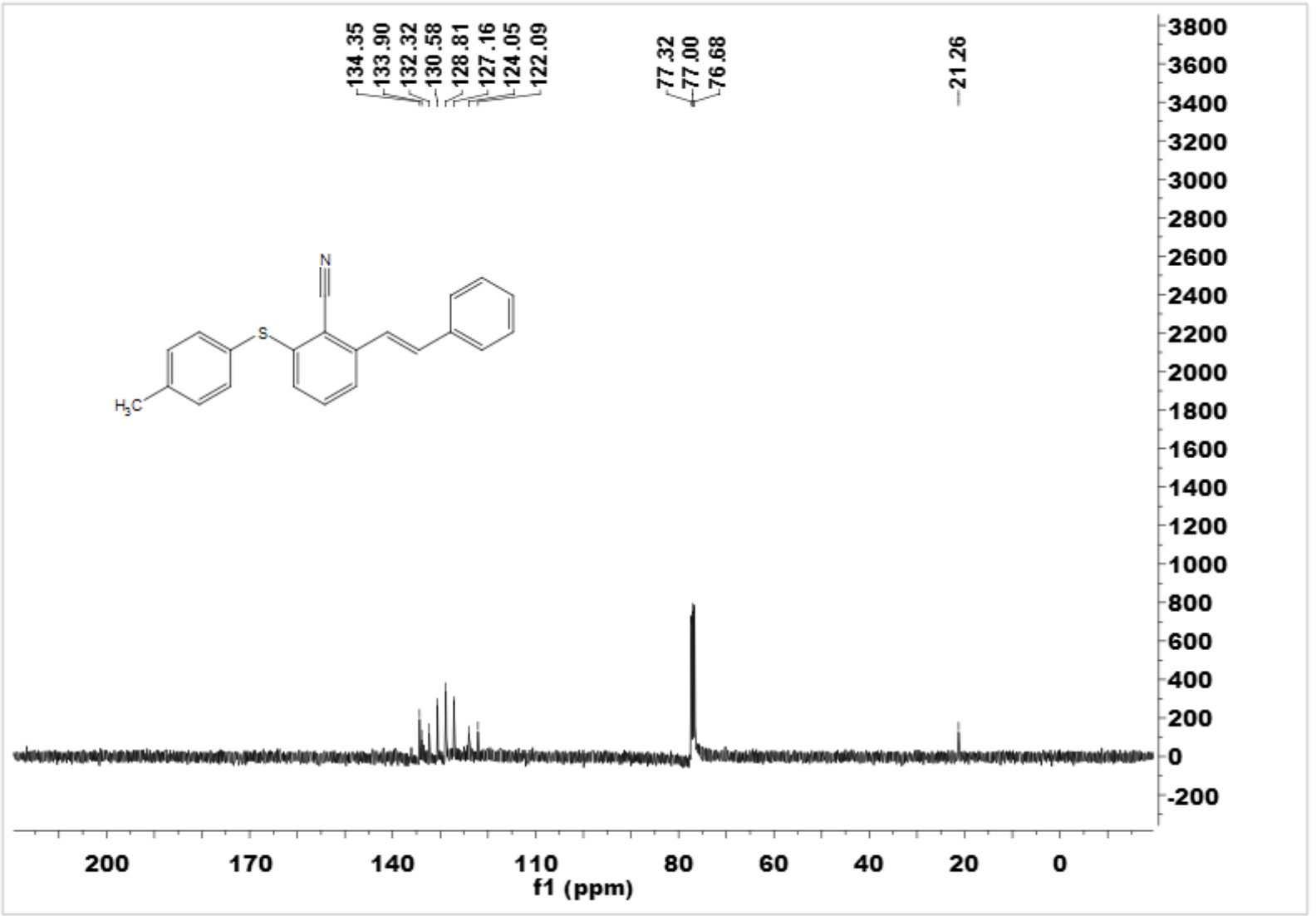

(E)-2-(4-(tert-Butyl)styryl)-4-methyl-6-(p-tolylthio)benzonitrile (4e)

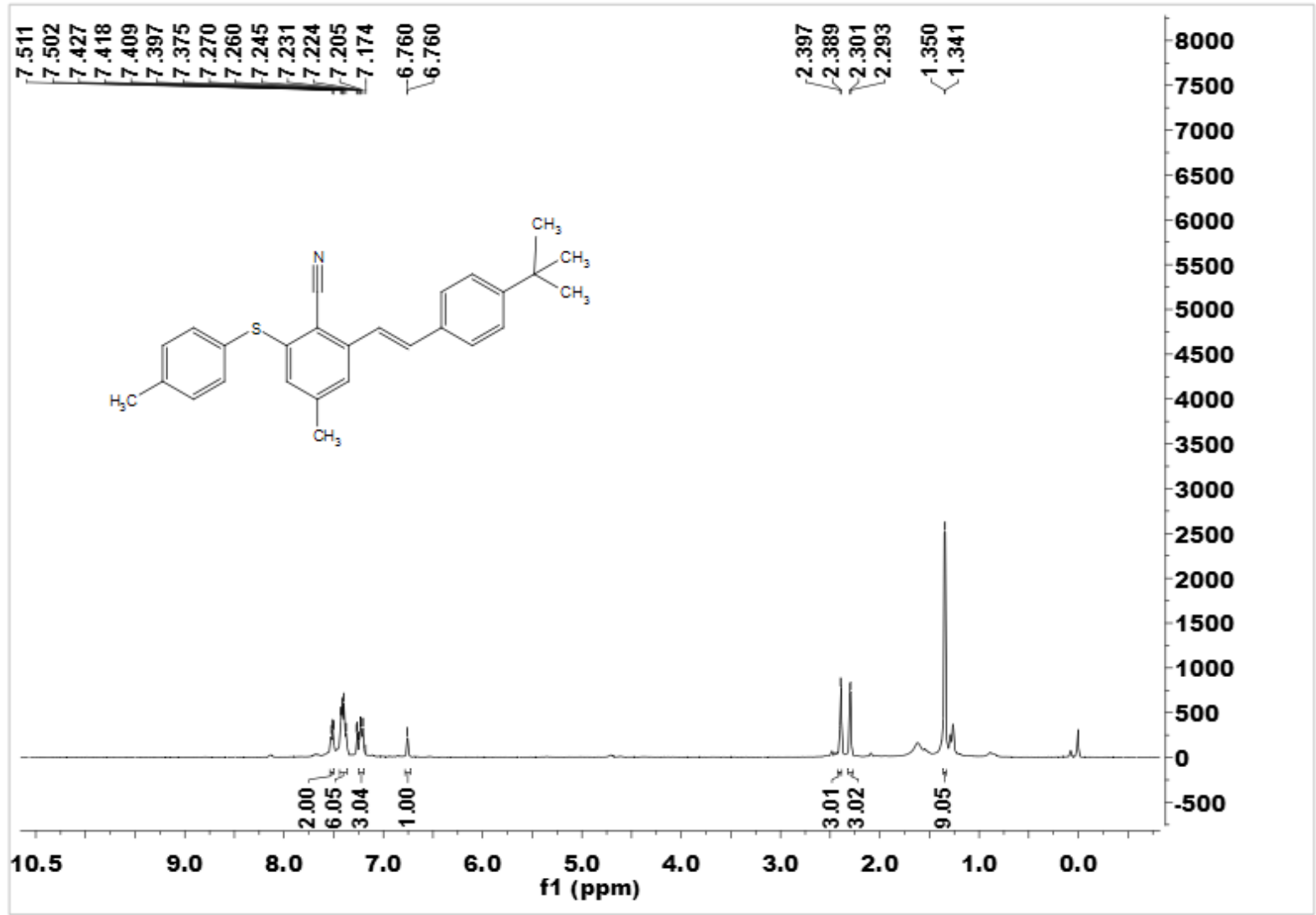




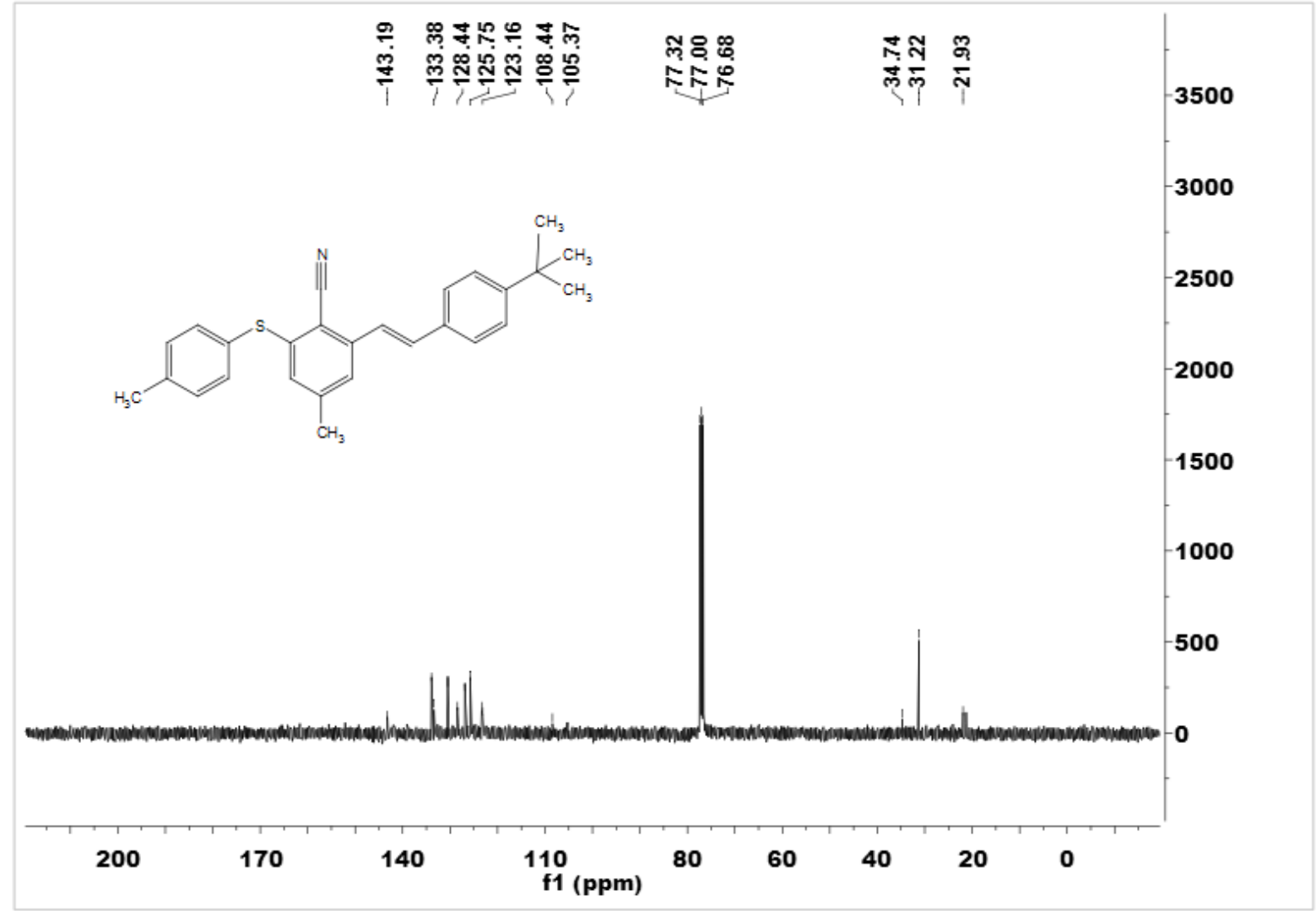

(E)-2-(4-(tert-Butyl)styryl)-4-methoxy-6-(p-tolylthio)benzonitrile (4f)

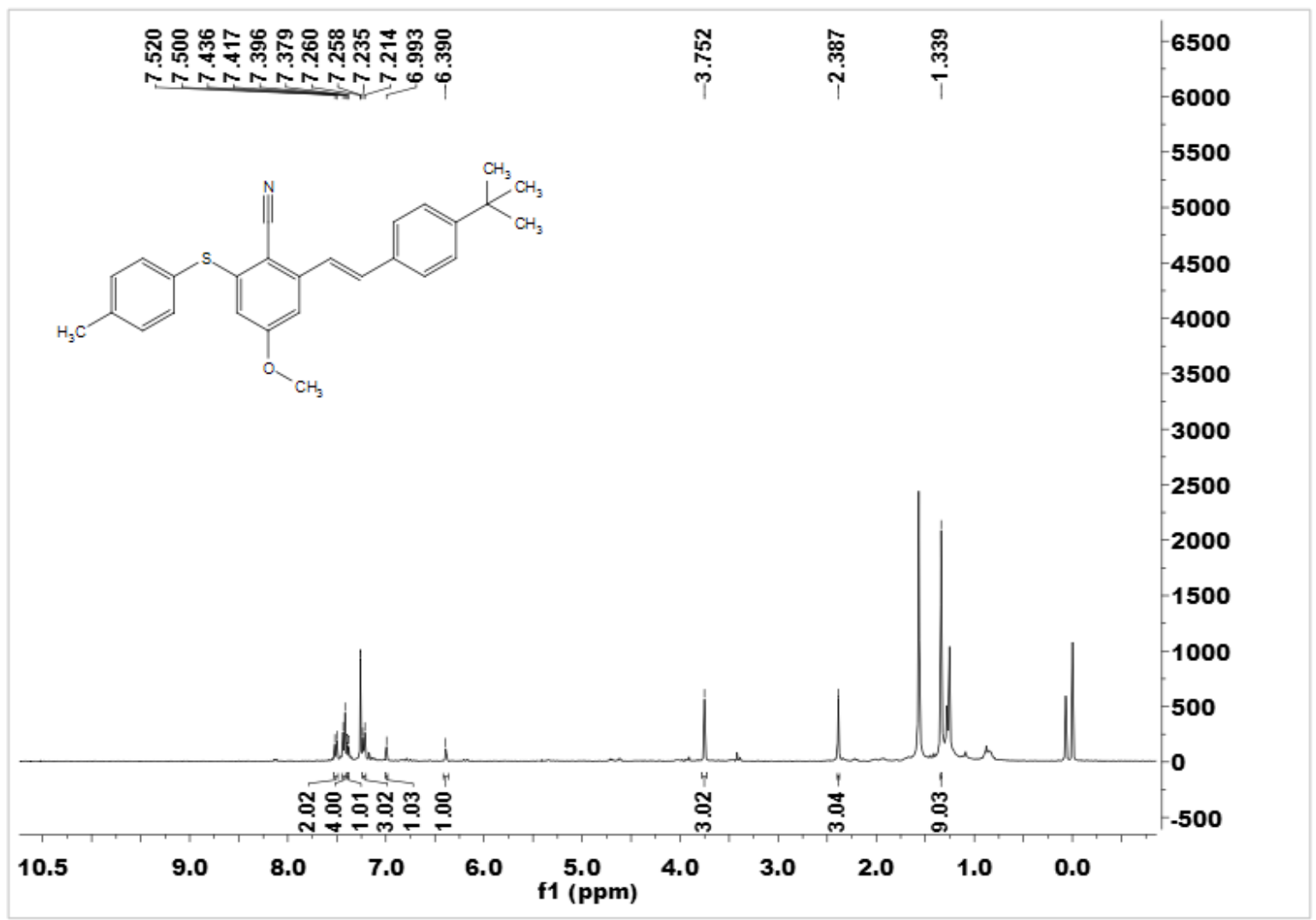




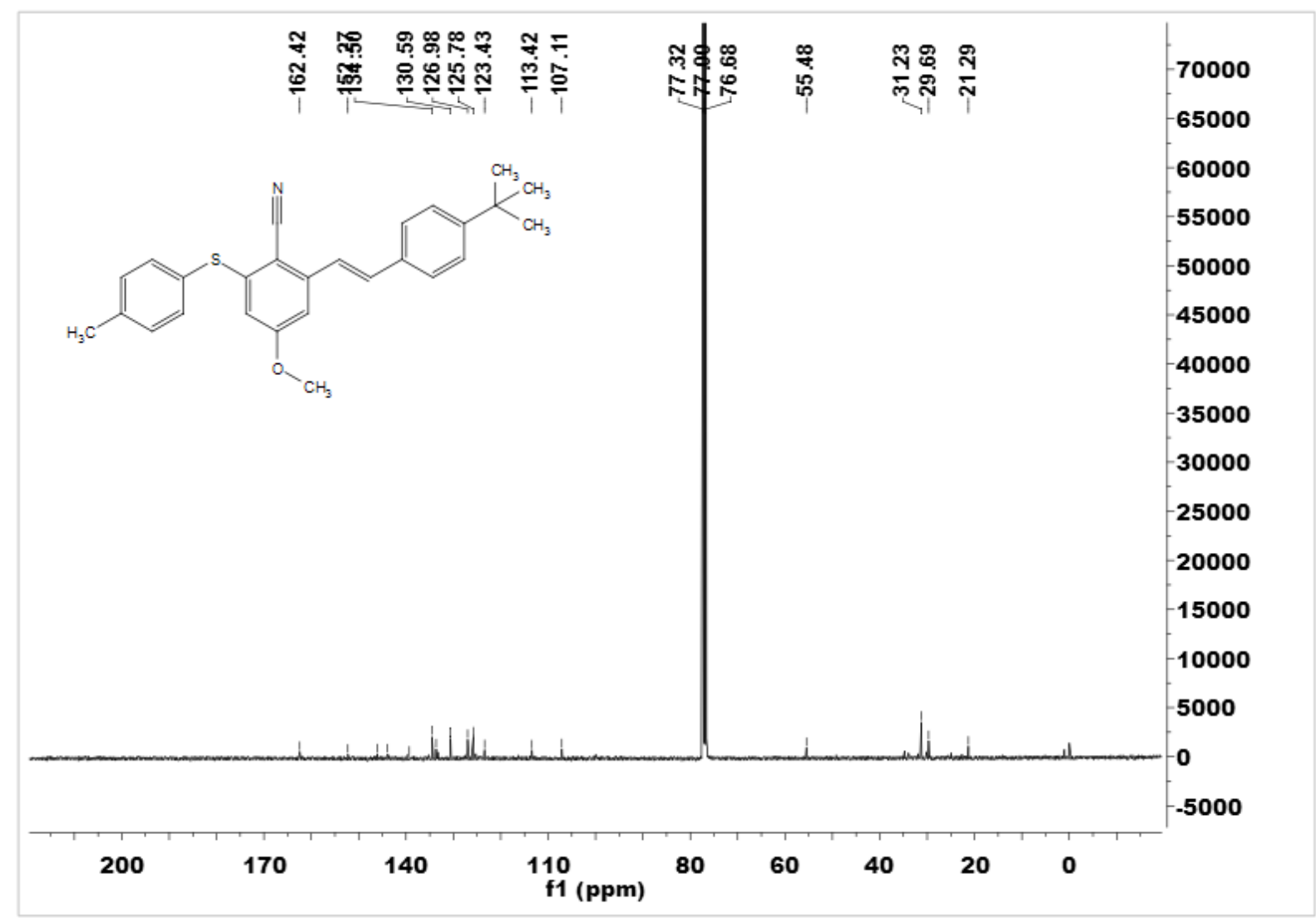

(E)-3-(3-(4-(tert-Butyl)styryl)-4-cyano-5-(p-tolylthio)phenoxy)propyl 2-(4-isopropylphenyl) propanoate $(4 g)$

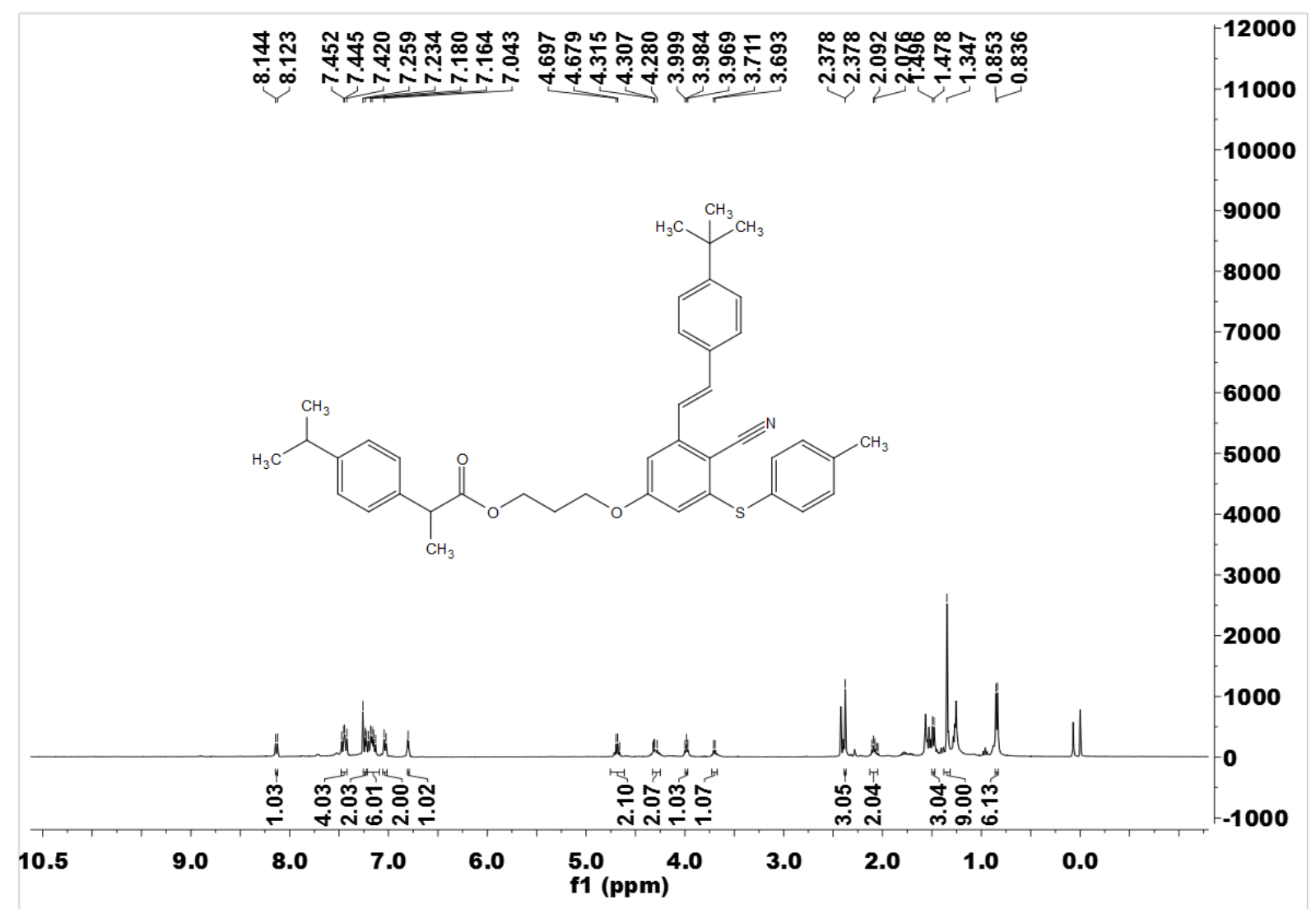




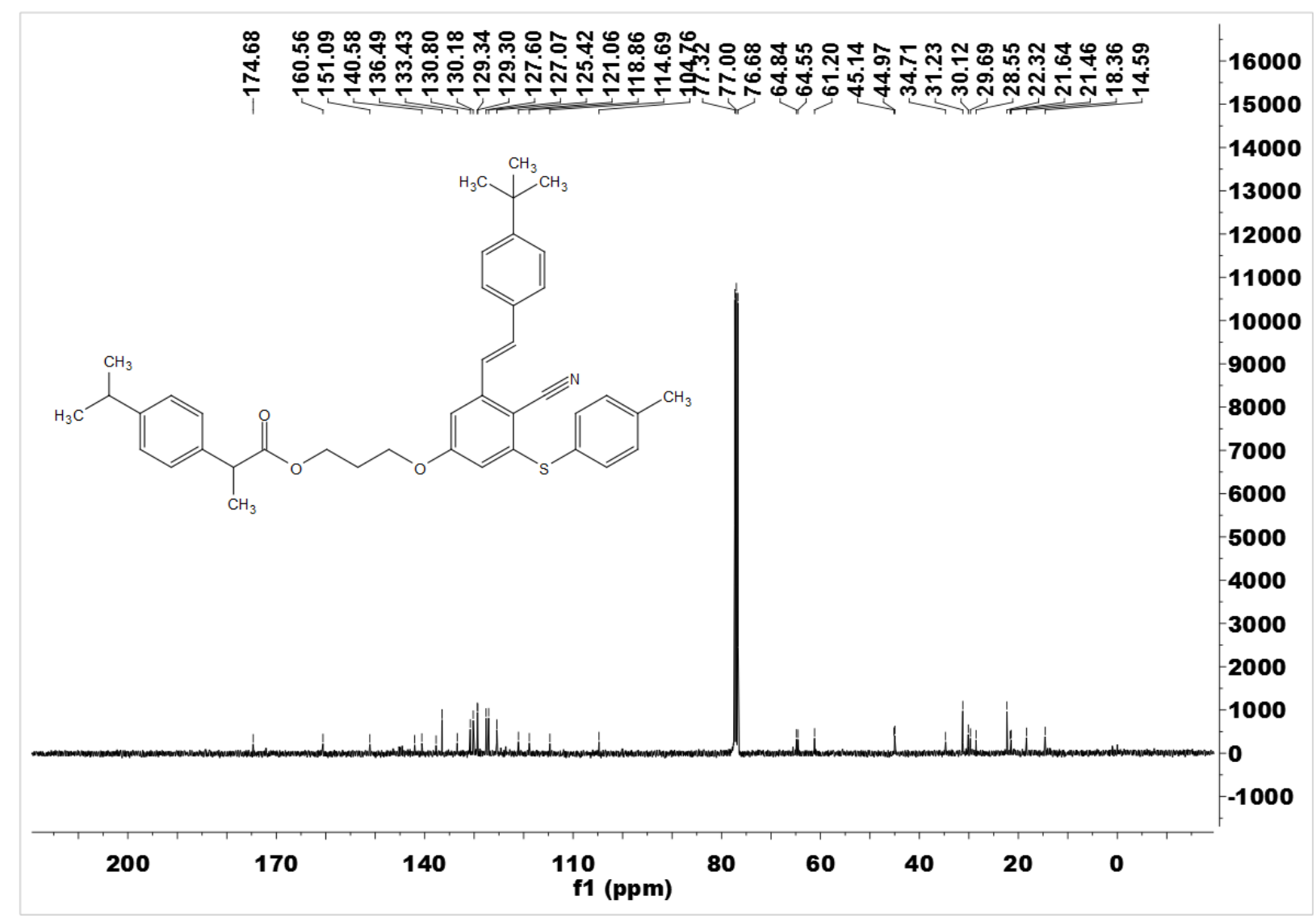

Ethyl (E)-2-(4-(tert-butyl)styryl)-6-((2,6-dimethylphenyl)thio)benzimidate (5a)

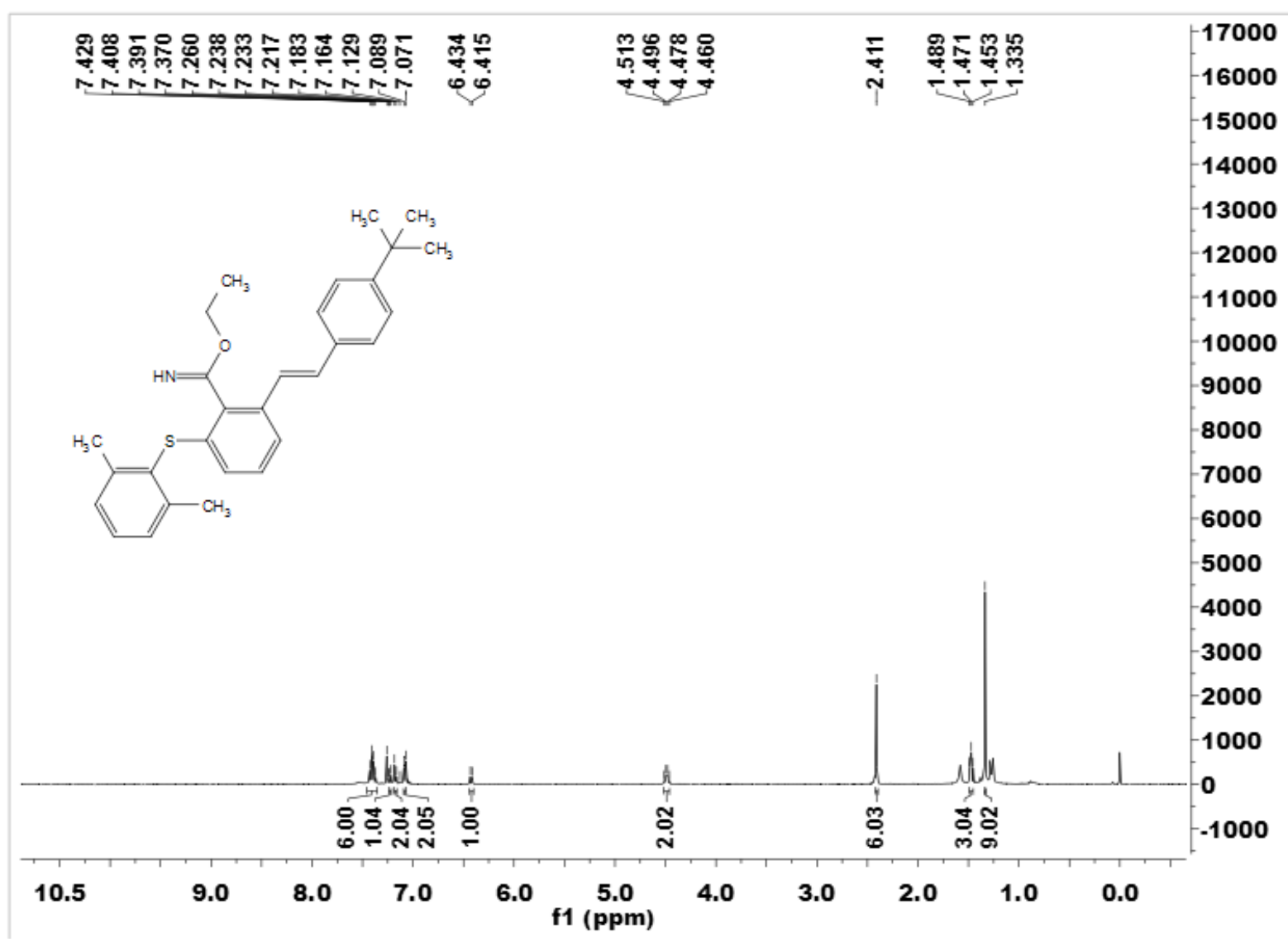




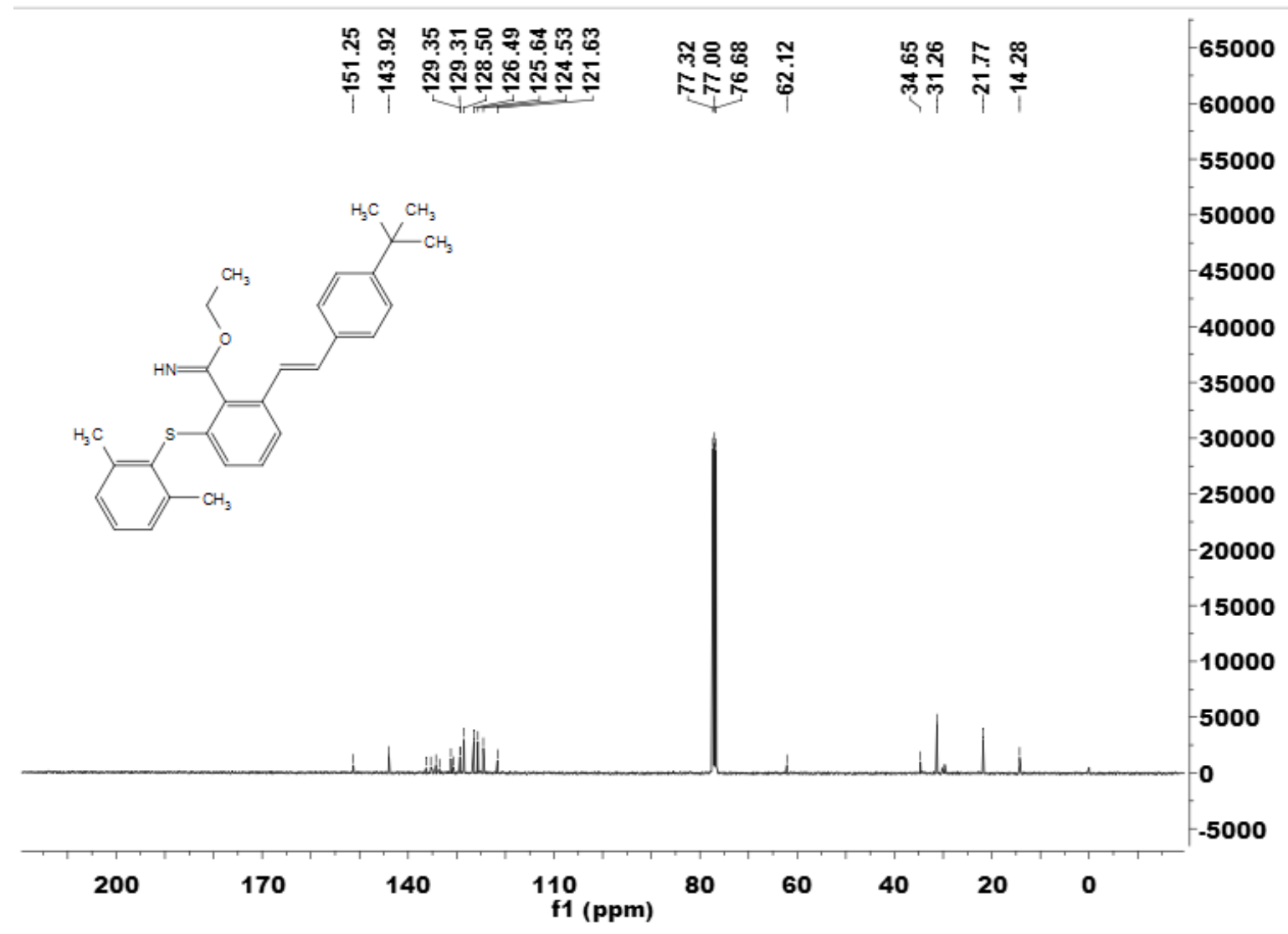

Ethyl (E)-2-(4-(tert-butyl)styryl)-6-((3,4-dimethylphenyl)thio)benzimidate (5b)

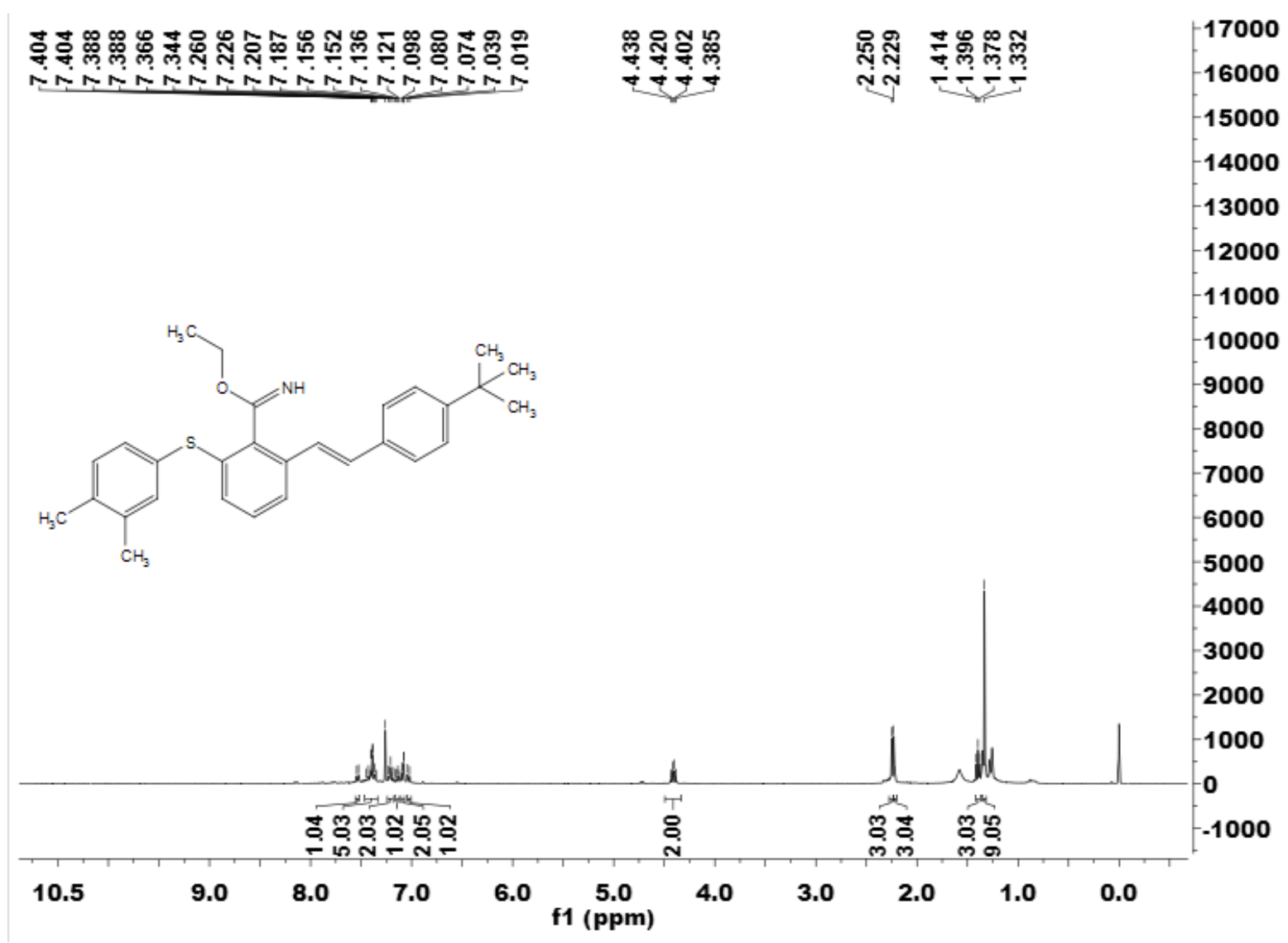




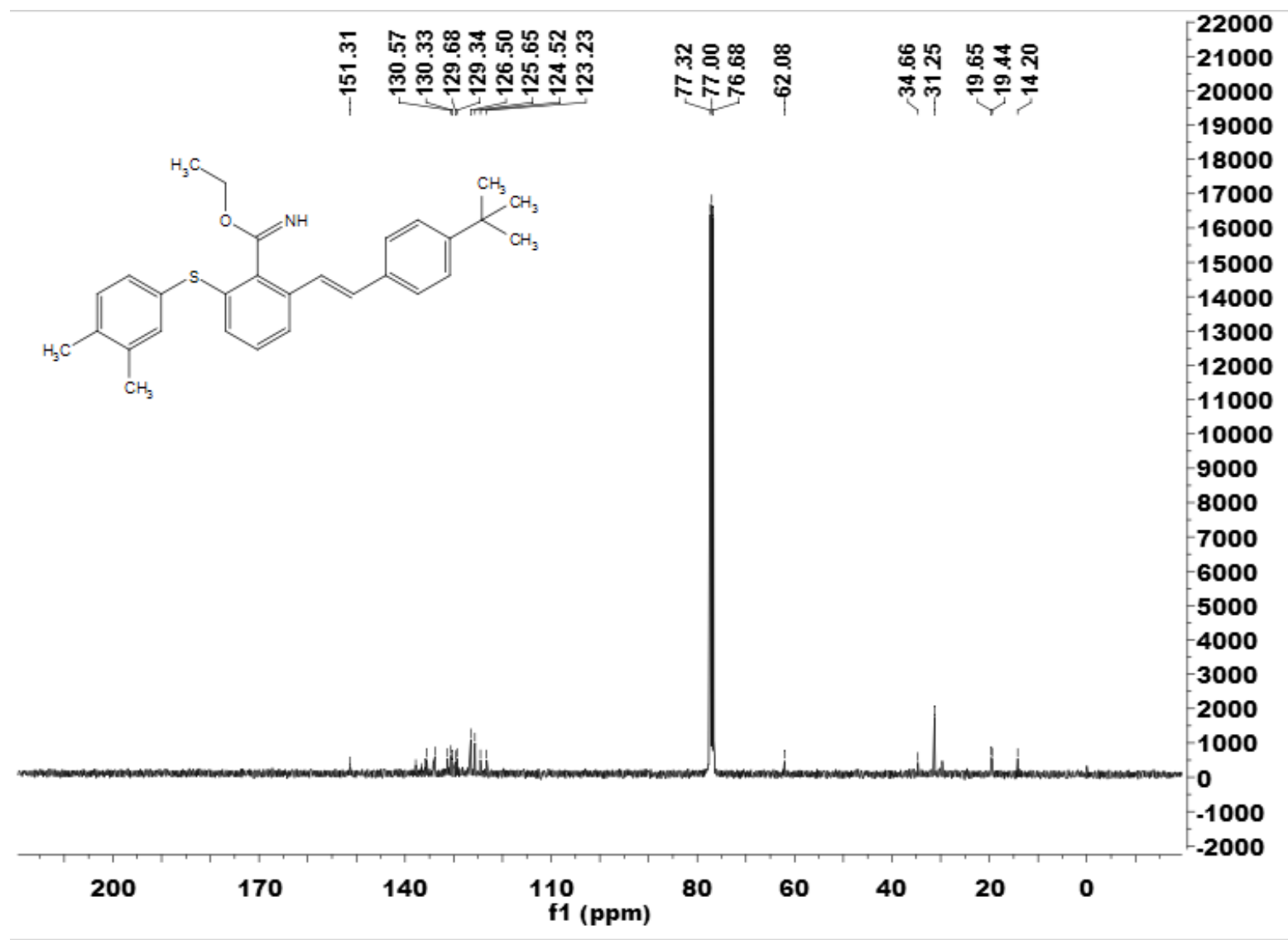

Ethyl (E)-2-(3,4-dimethylstyryl)-6-(p-tolylthio)benzimidate (5c)

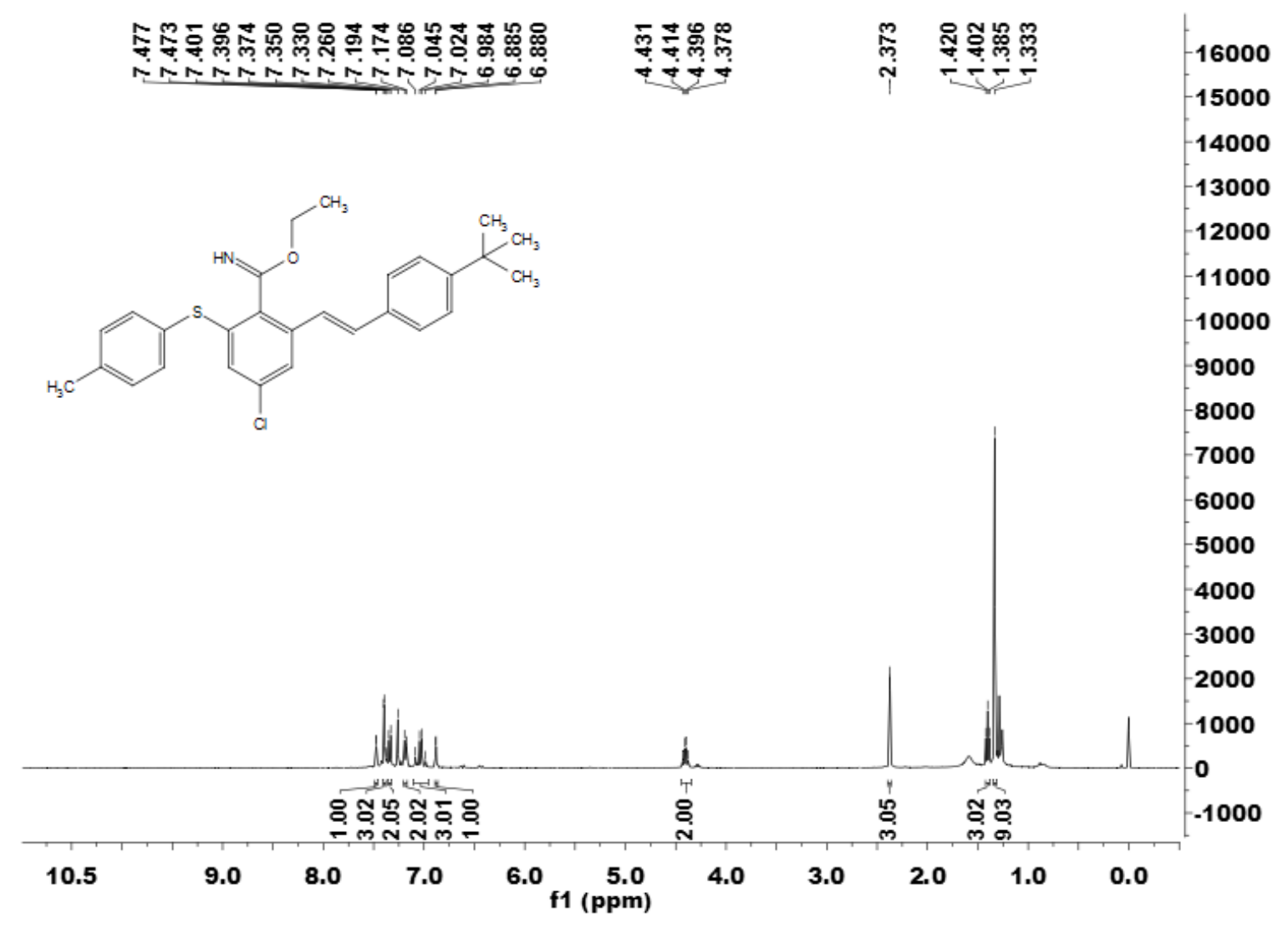




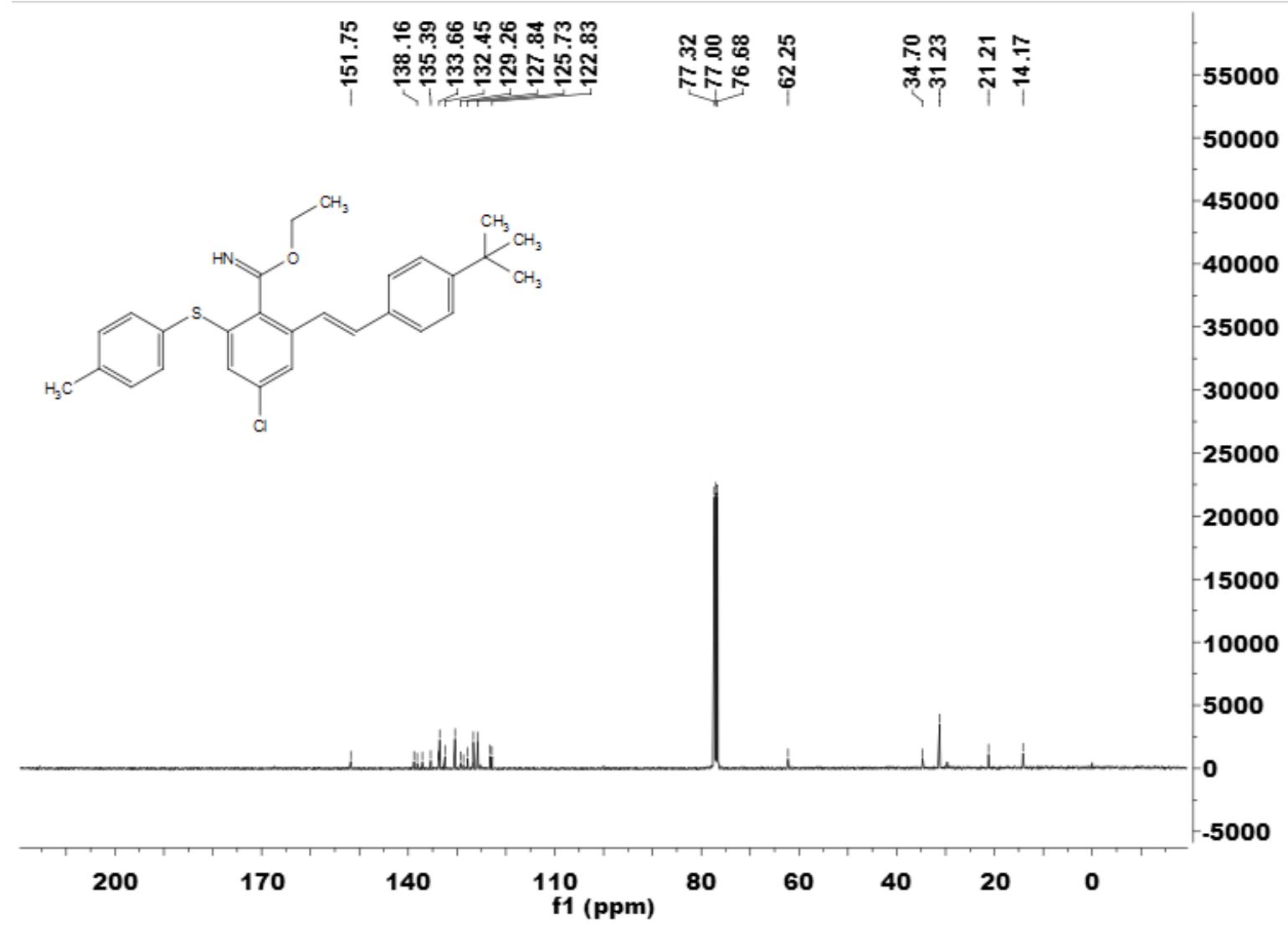

Ethyl (E)-2-(4-chlorostyryl)-6-(phenylthio)benzimidate (5d)

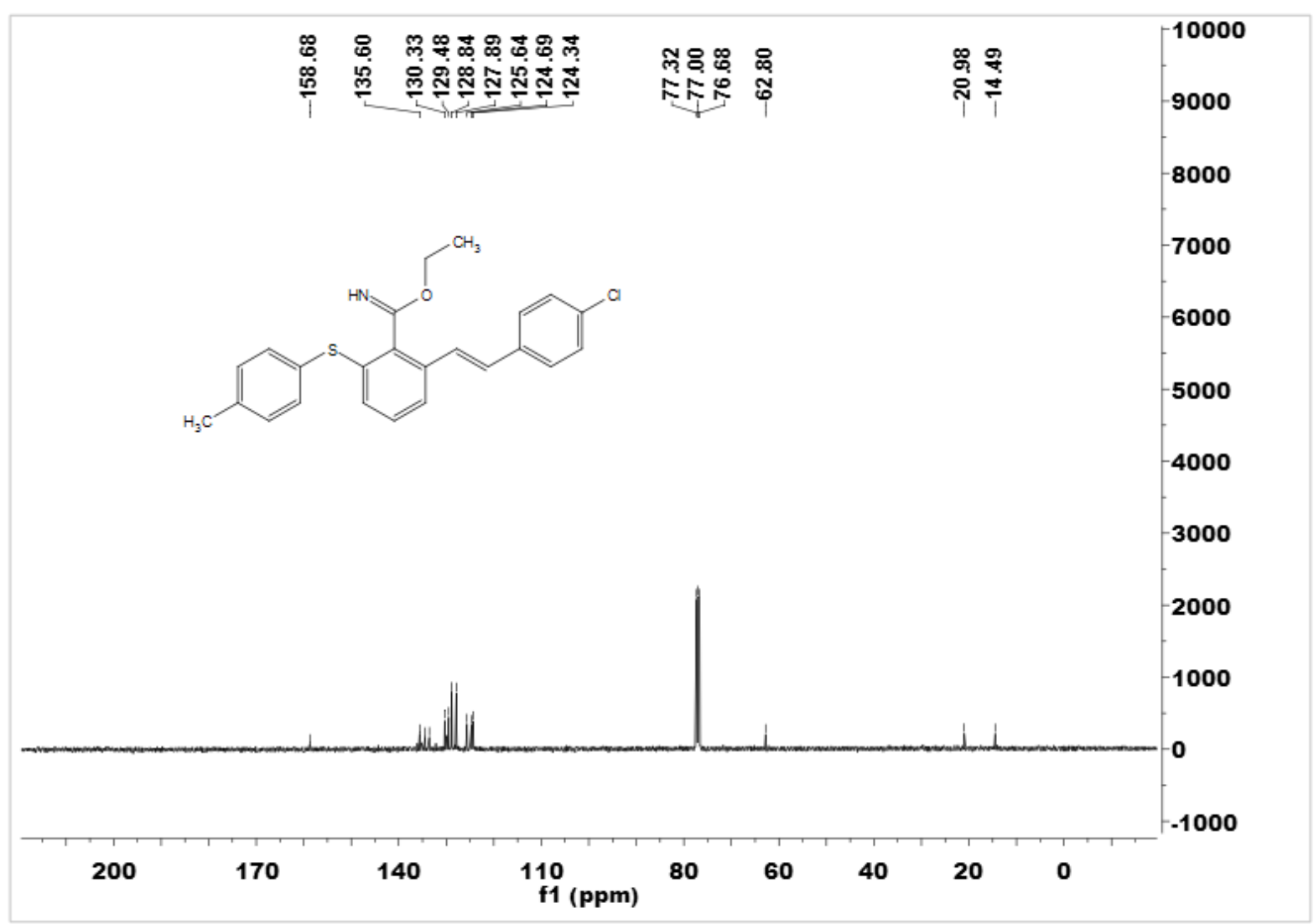




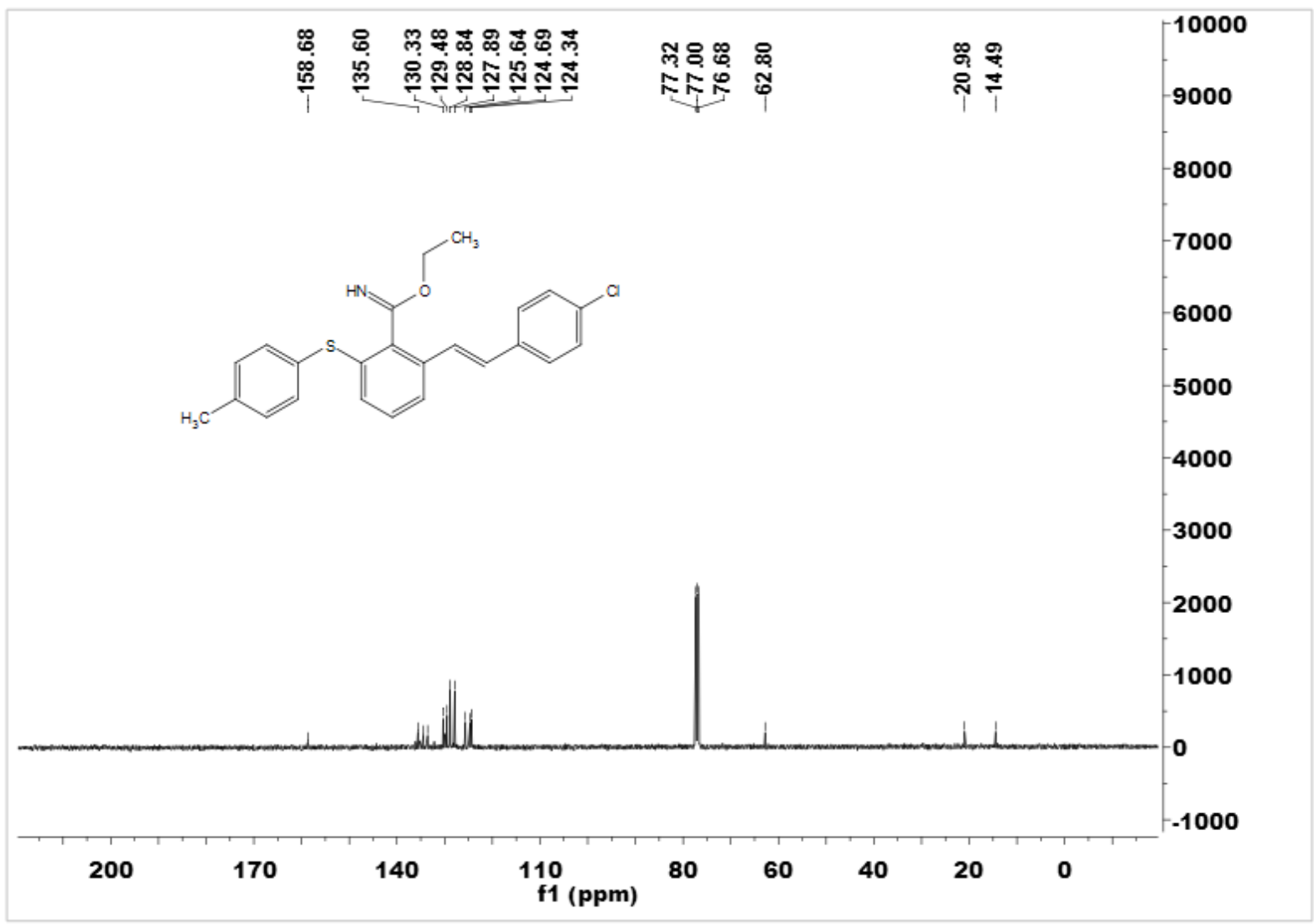

Ethyl (E)-2-(4-bromostyryl)-6-(p-tolylthio)benzimidate (5e)

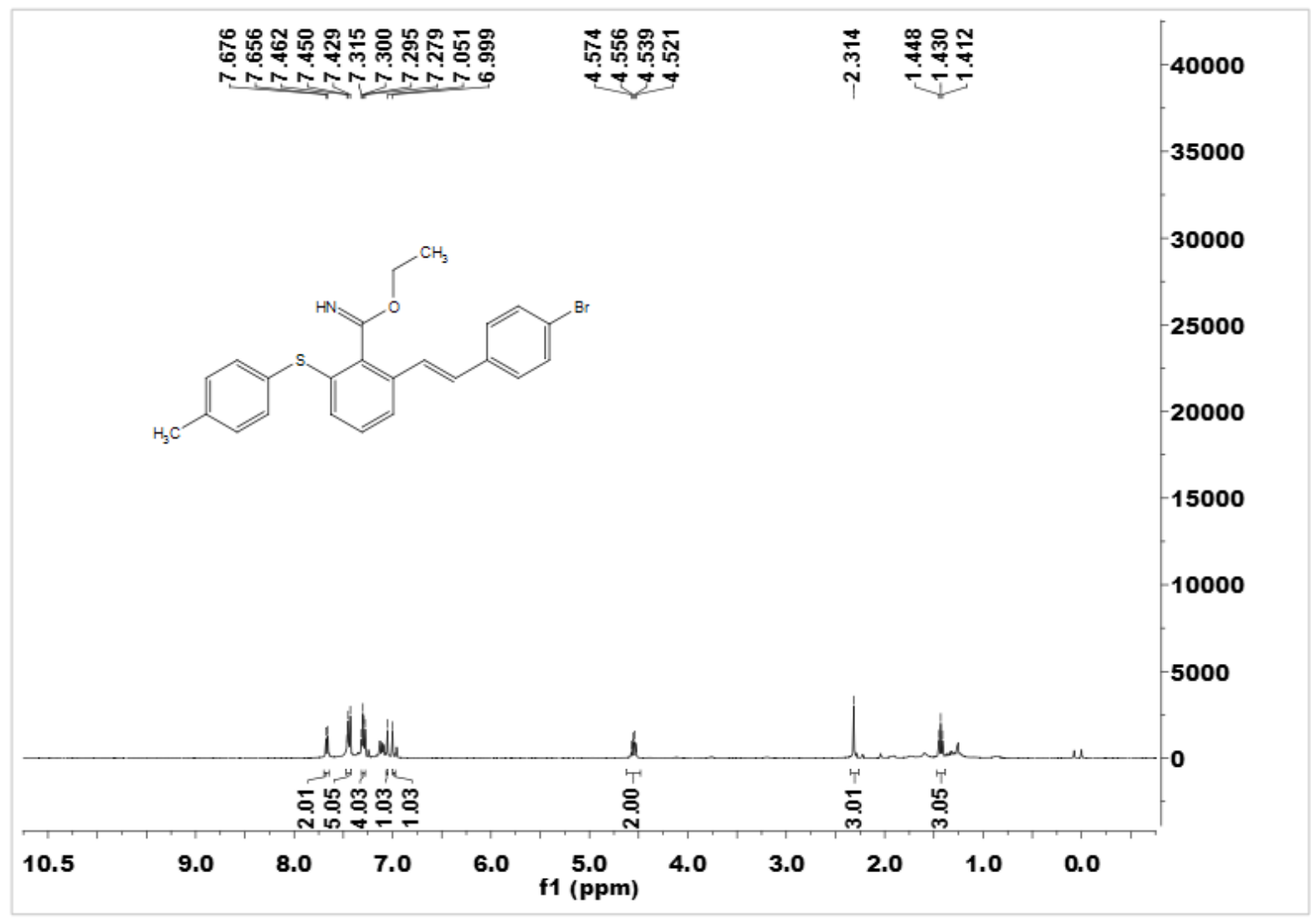




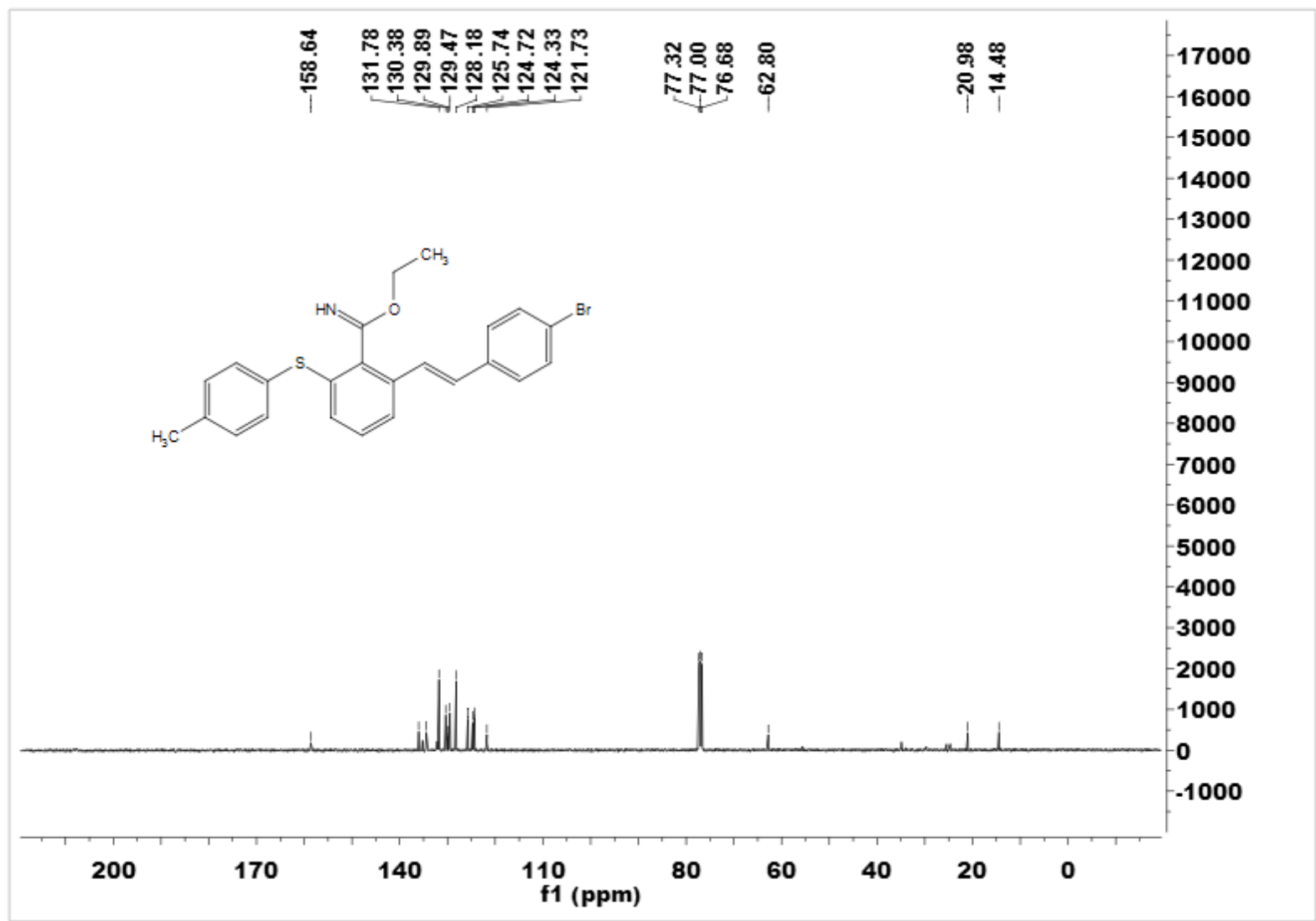

Ethyl (E)-2-((4-(tert-butyl)phenyl)thio)-6-(4-(tert-butyl)styryl)-4-methylbenzimidate (5f)

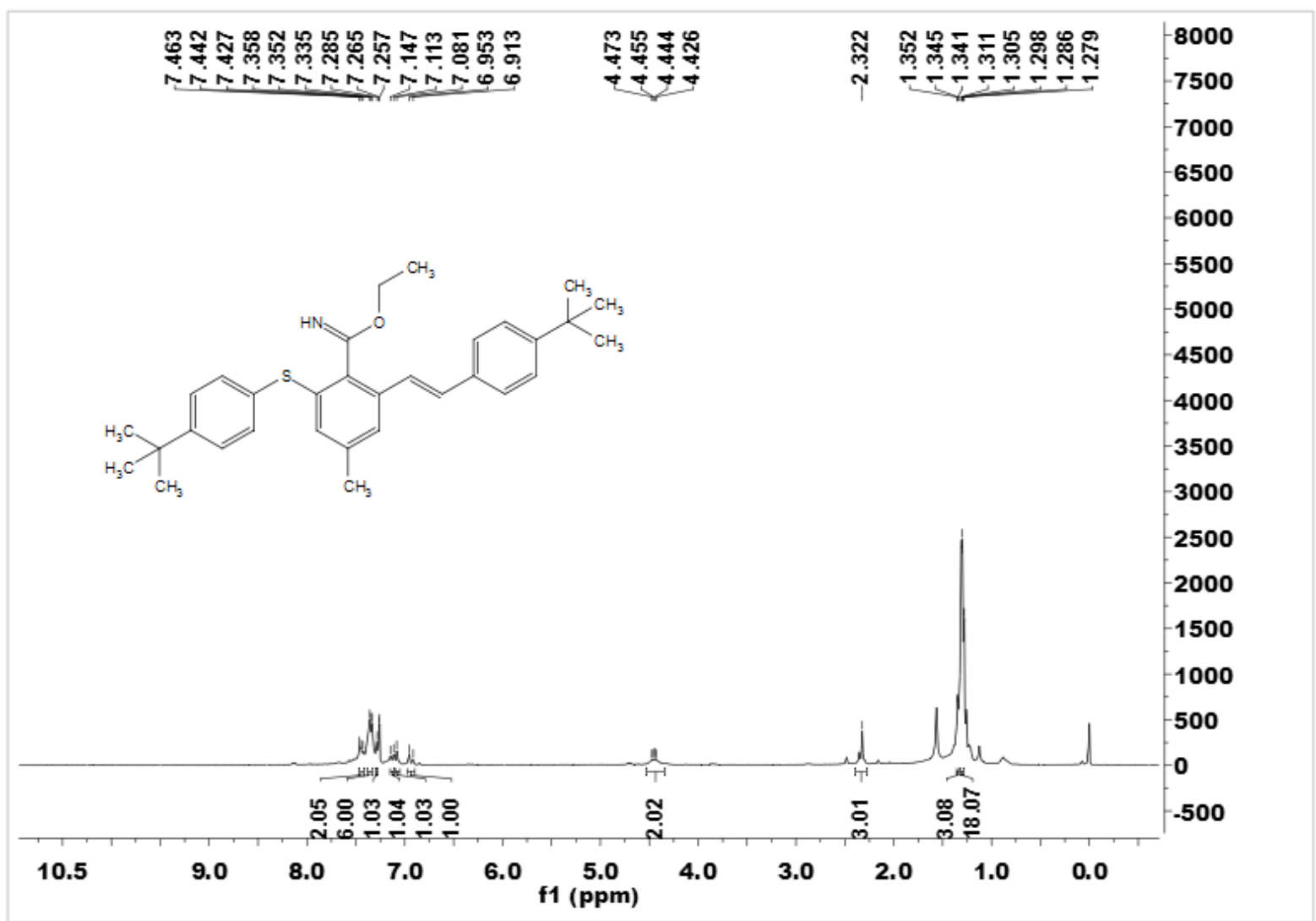




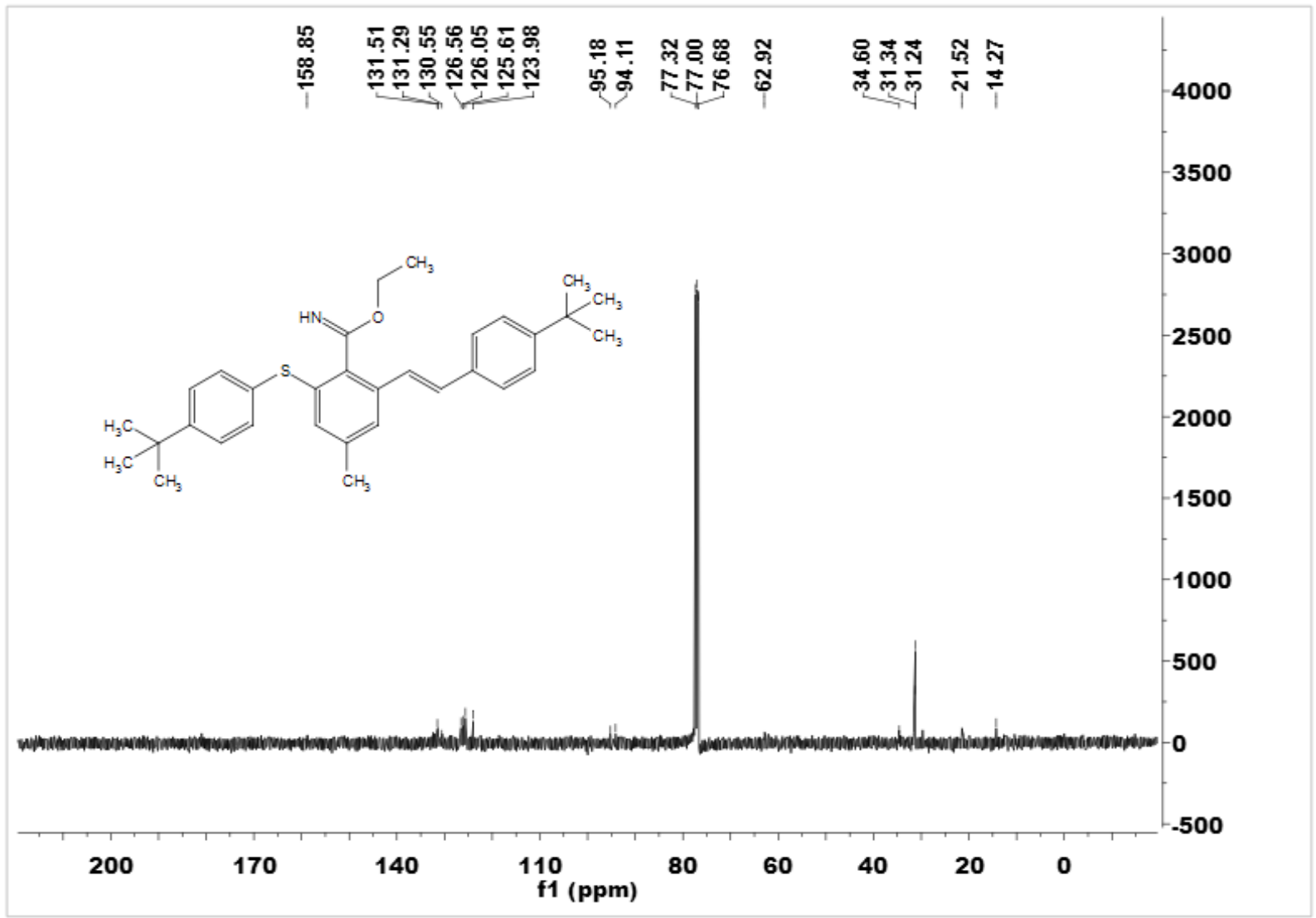

Ethyl (E)-3-(4-(tert-butyl)styryl)-1-(p-tolylthio)-2-naphthimidate (5g)

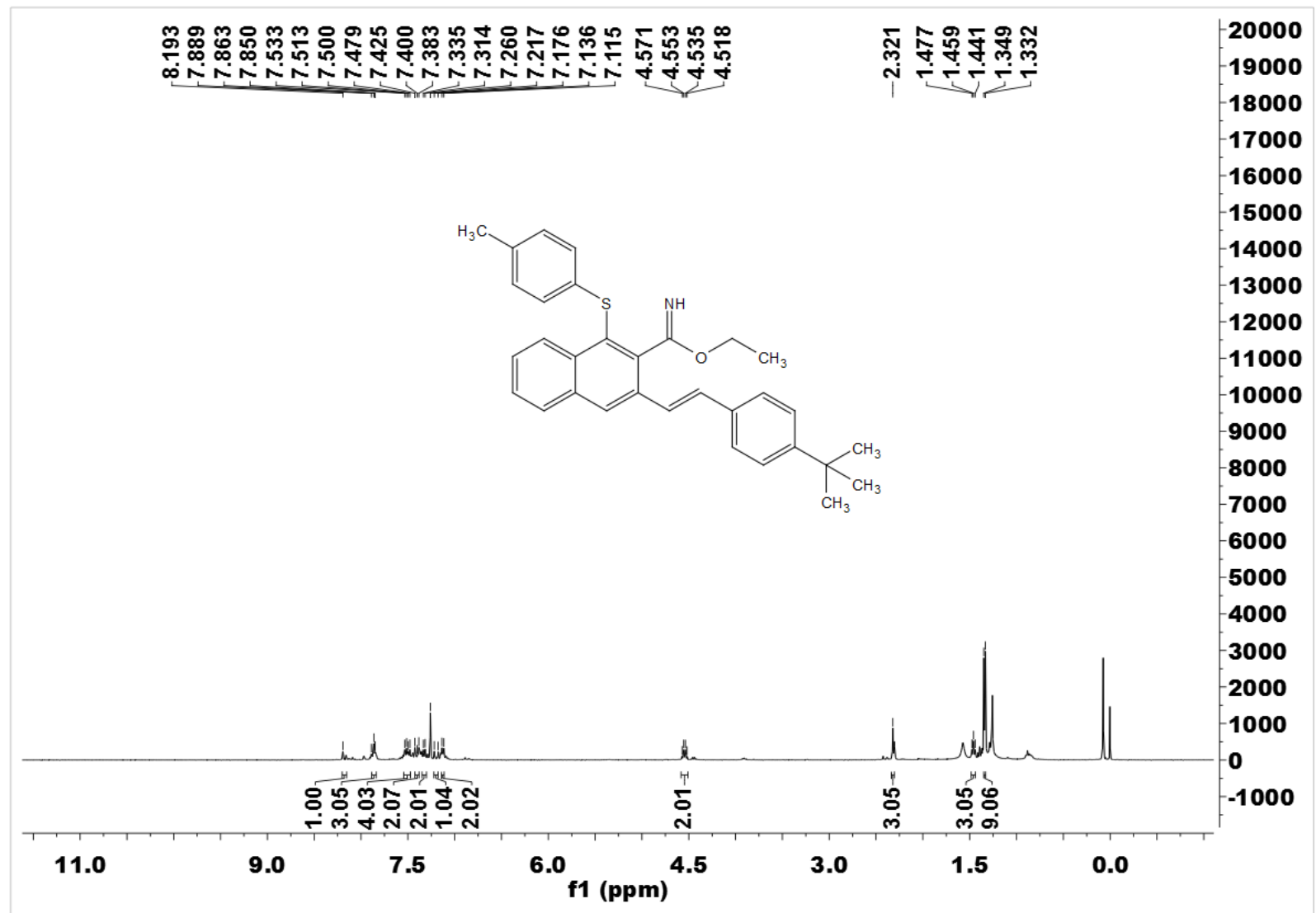




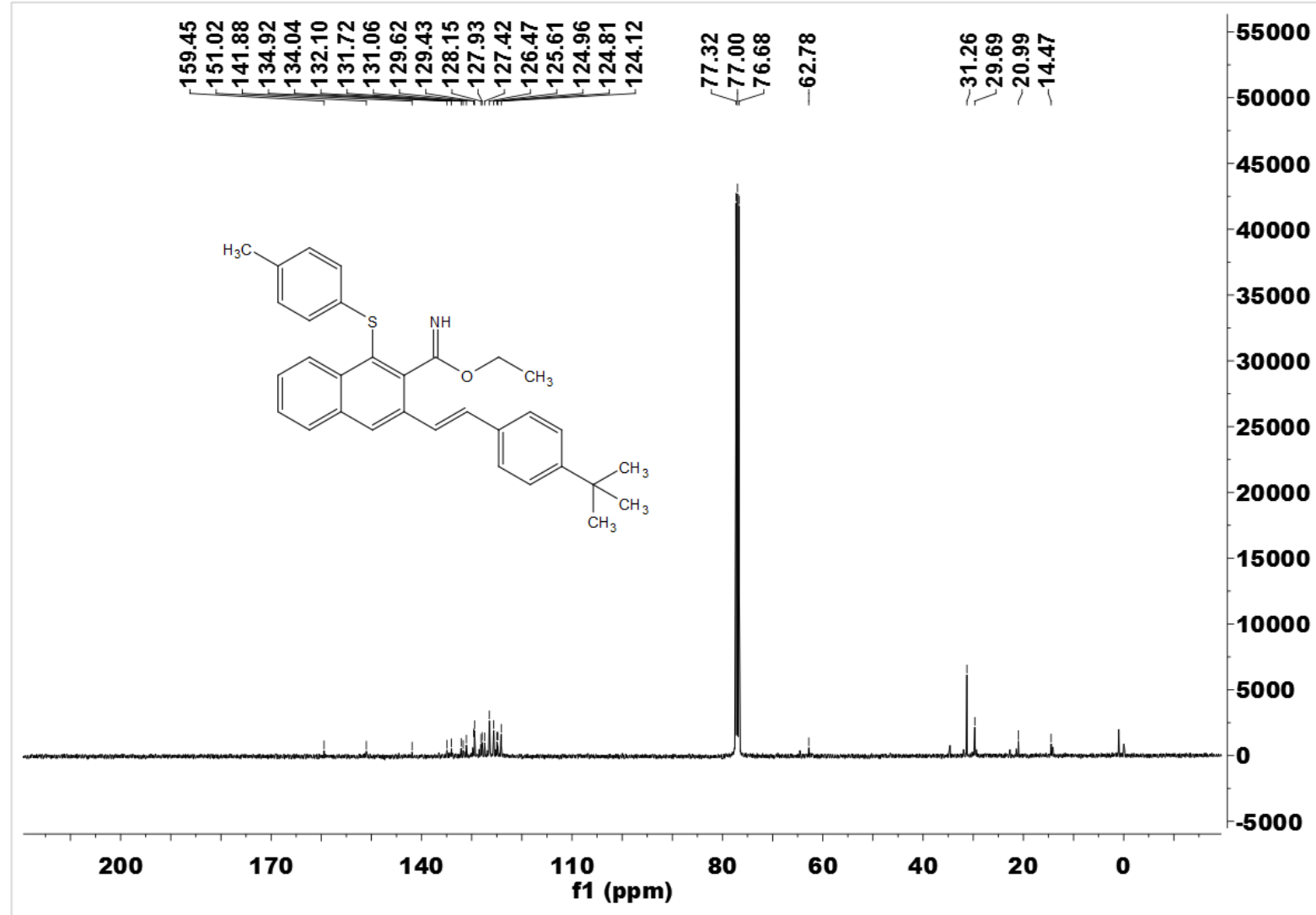

(E)-2-([2,2'-Bithiophen]-5-yl)-6-(4-(tert-butyl)styryl)benzonitrile (7a)

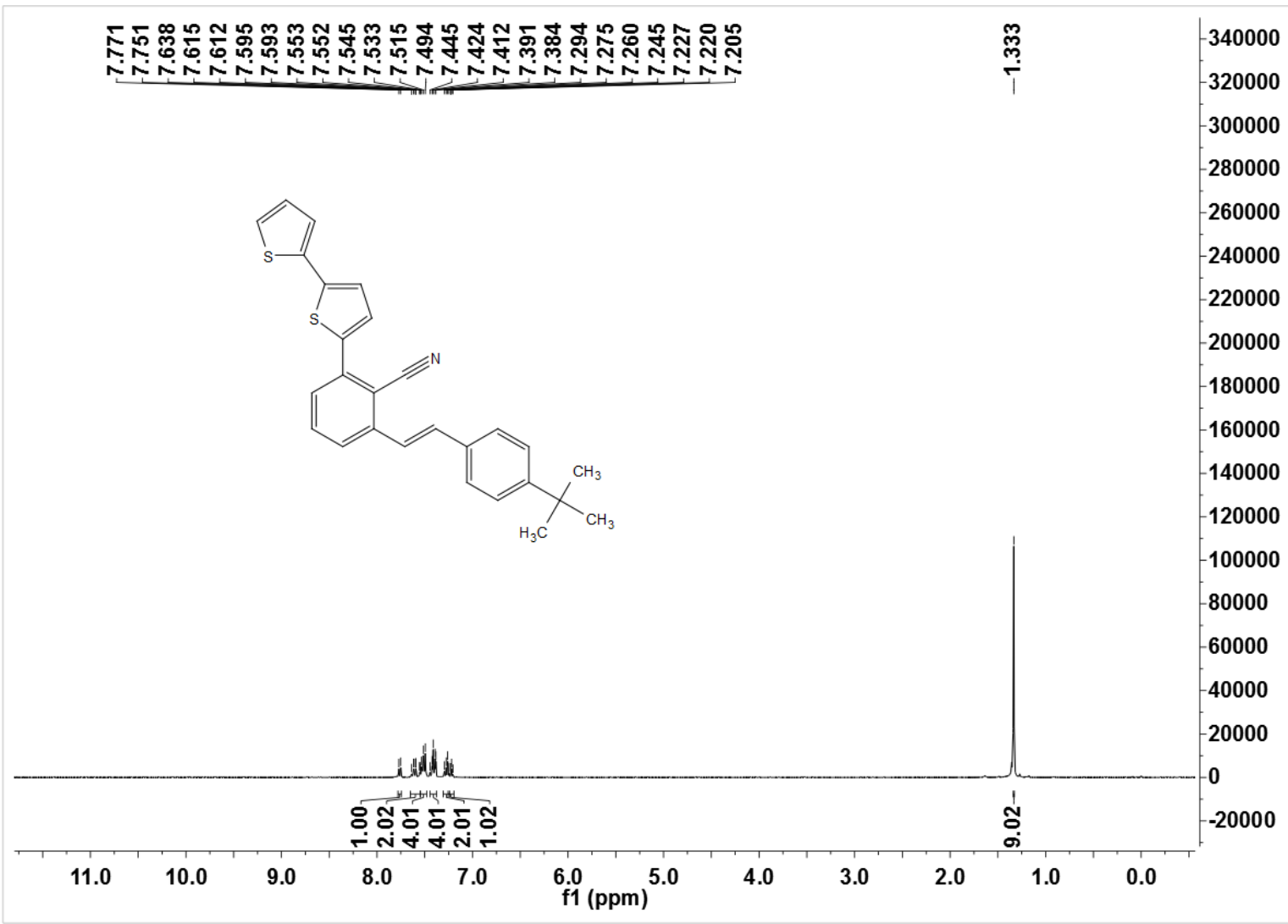




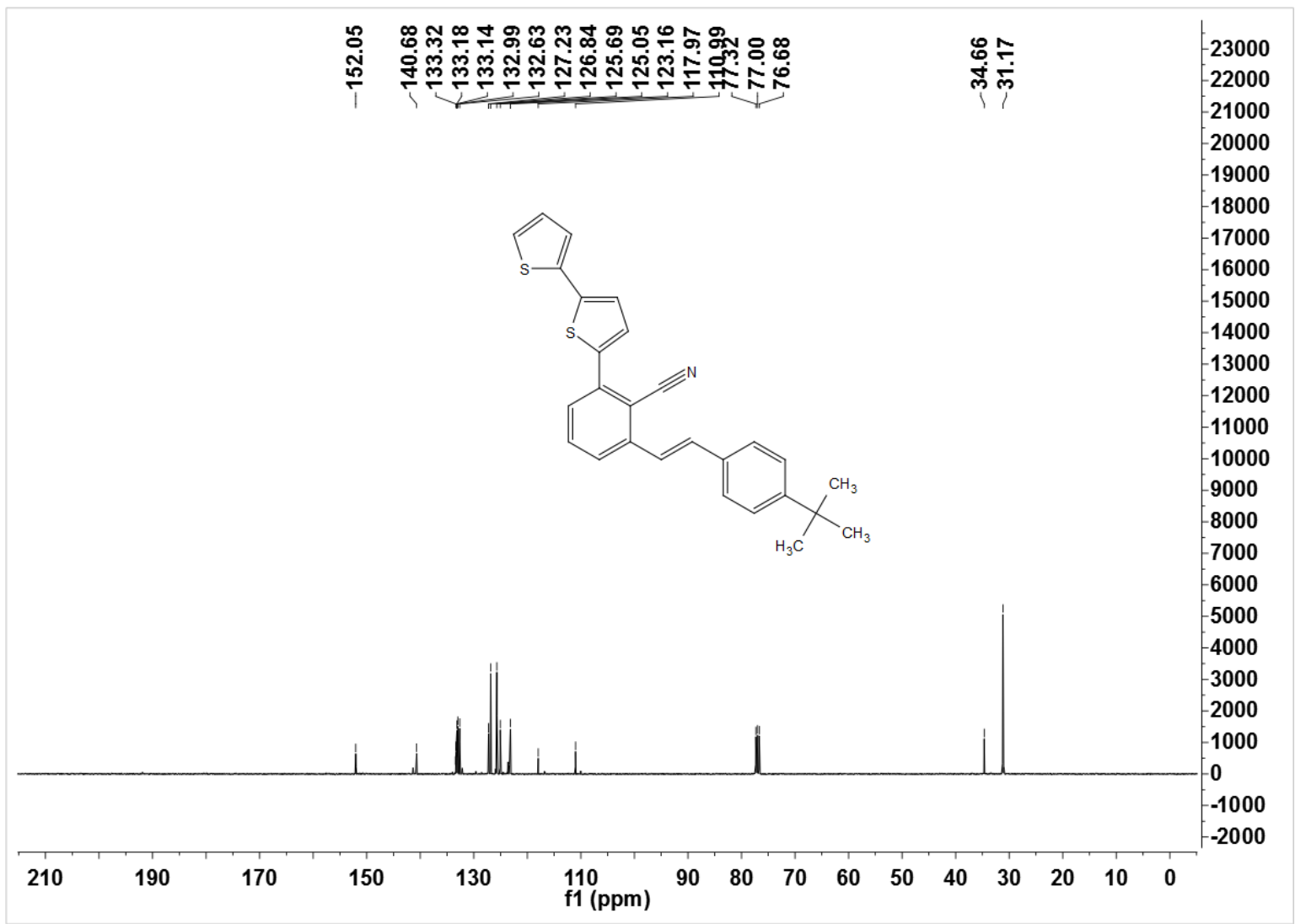

(E)-2-(Benzo[b]thiophen-2-yl)-6-(4-(tert-butyl)styryl)benzonitrile (7b)

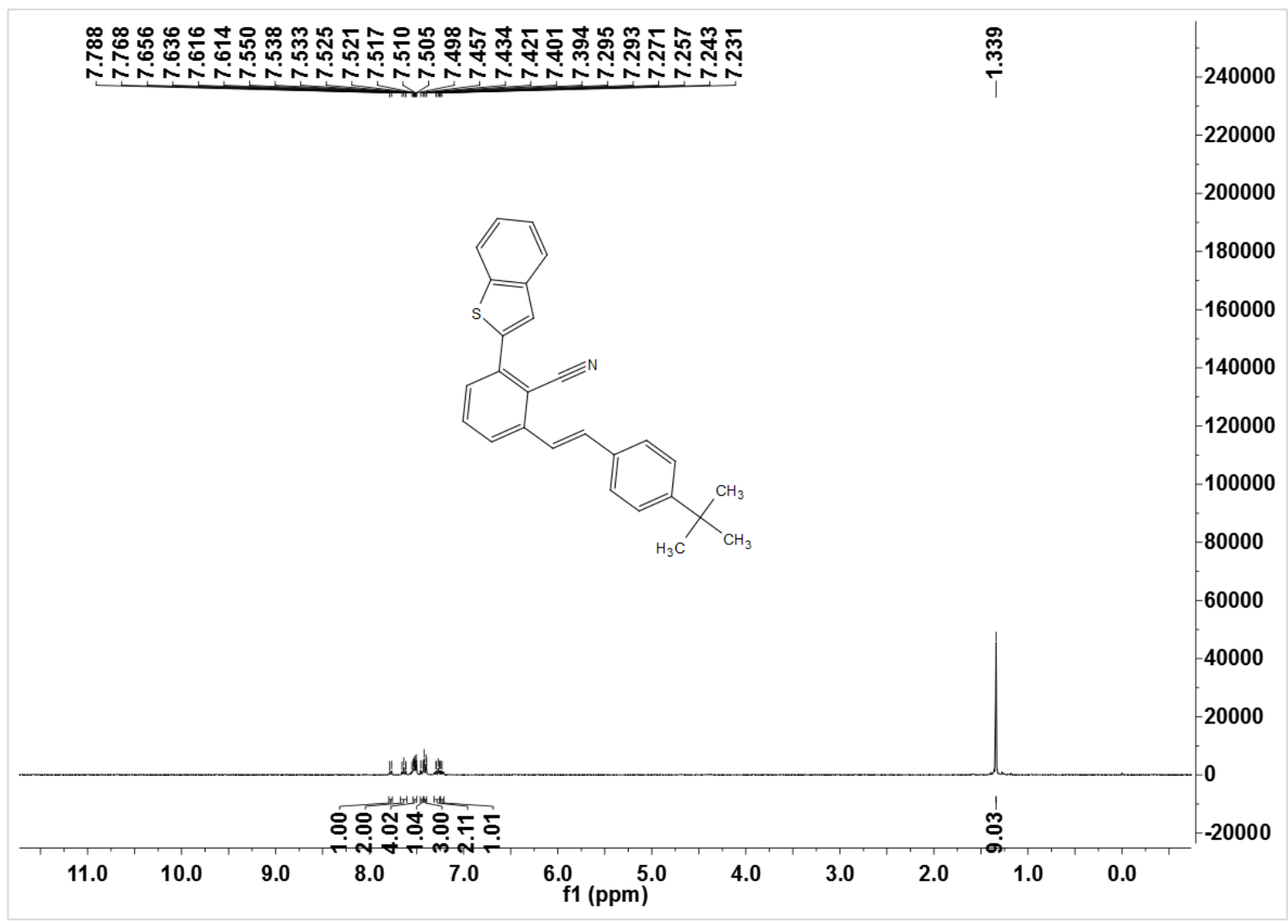




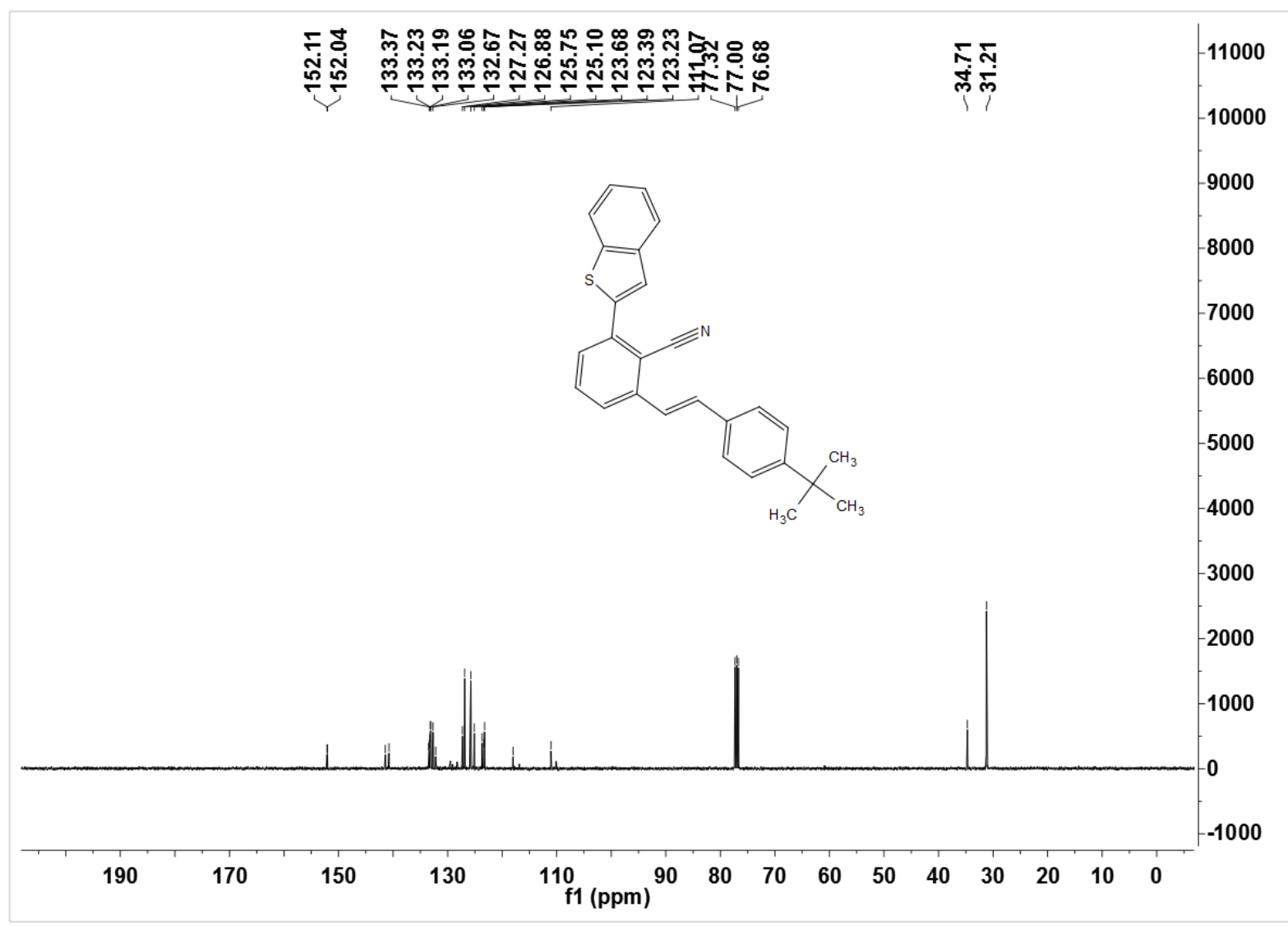

\section{2-(Phenylthio)benzonitrile (8a)}

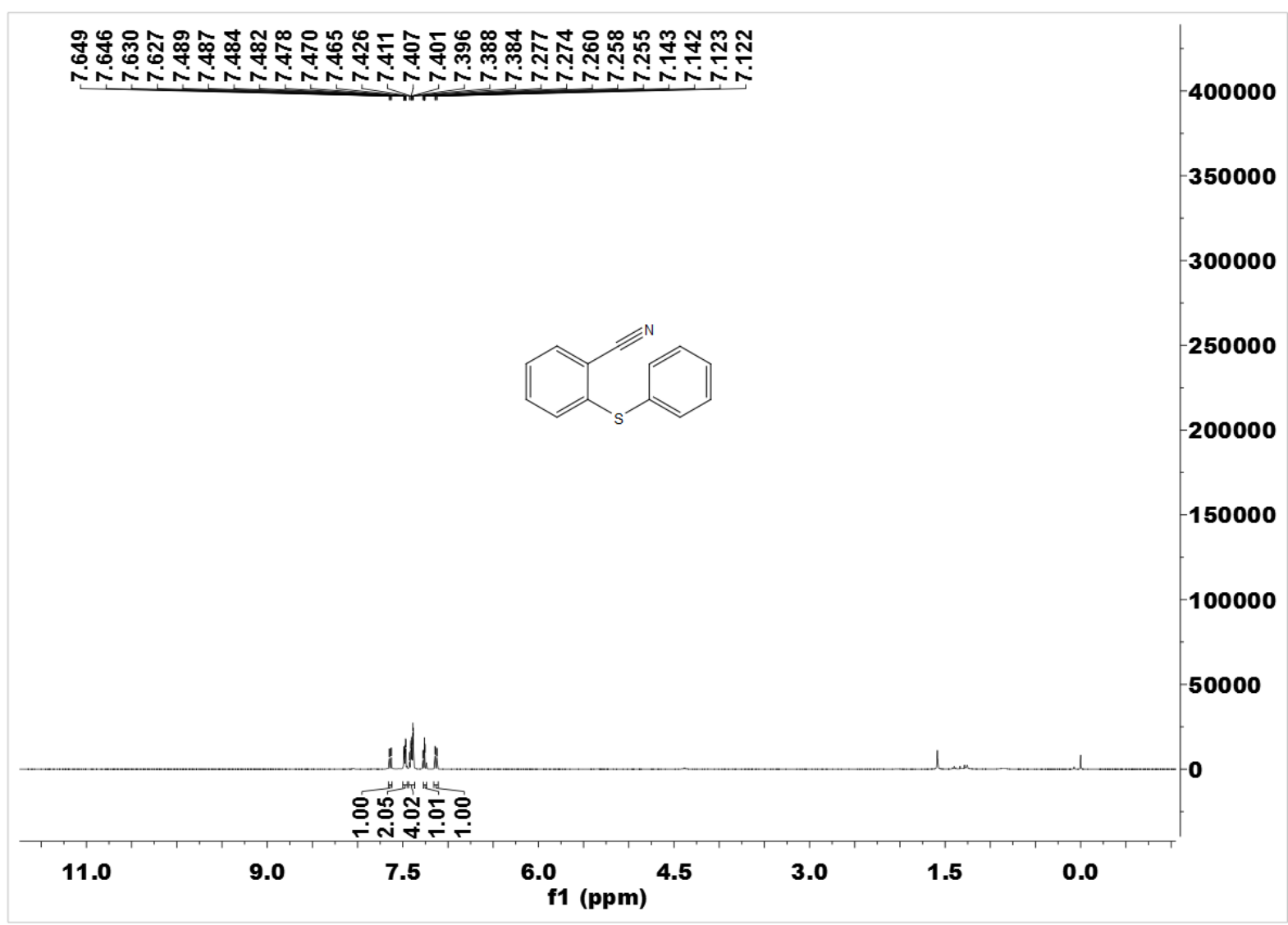




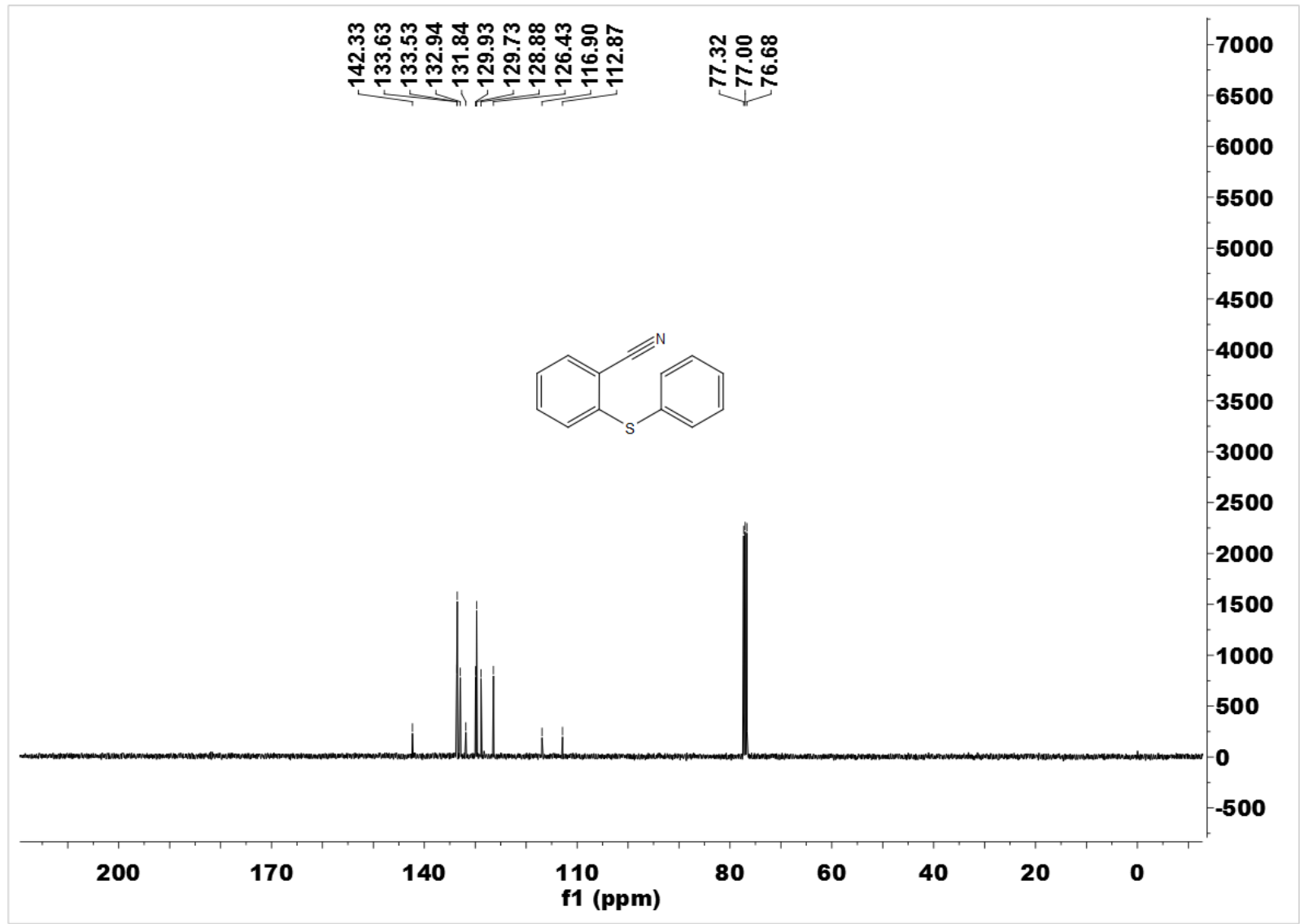

4-Fluoro-2-(phenylthio)benzonitrile (8b)

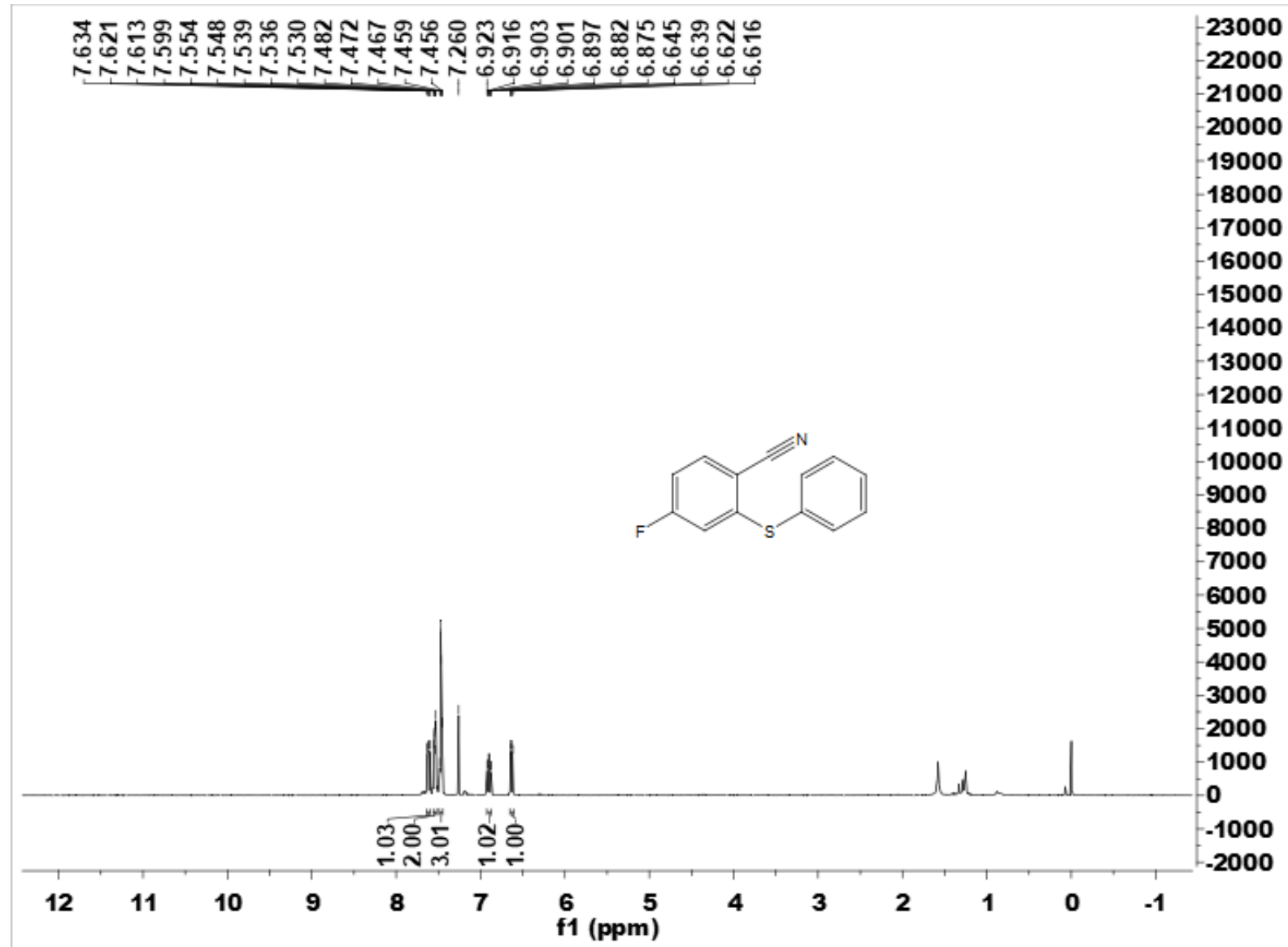



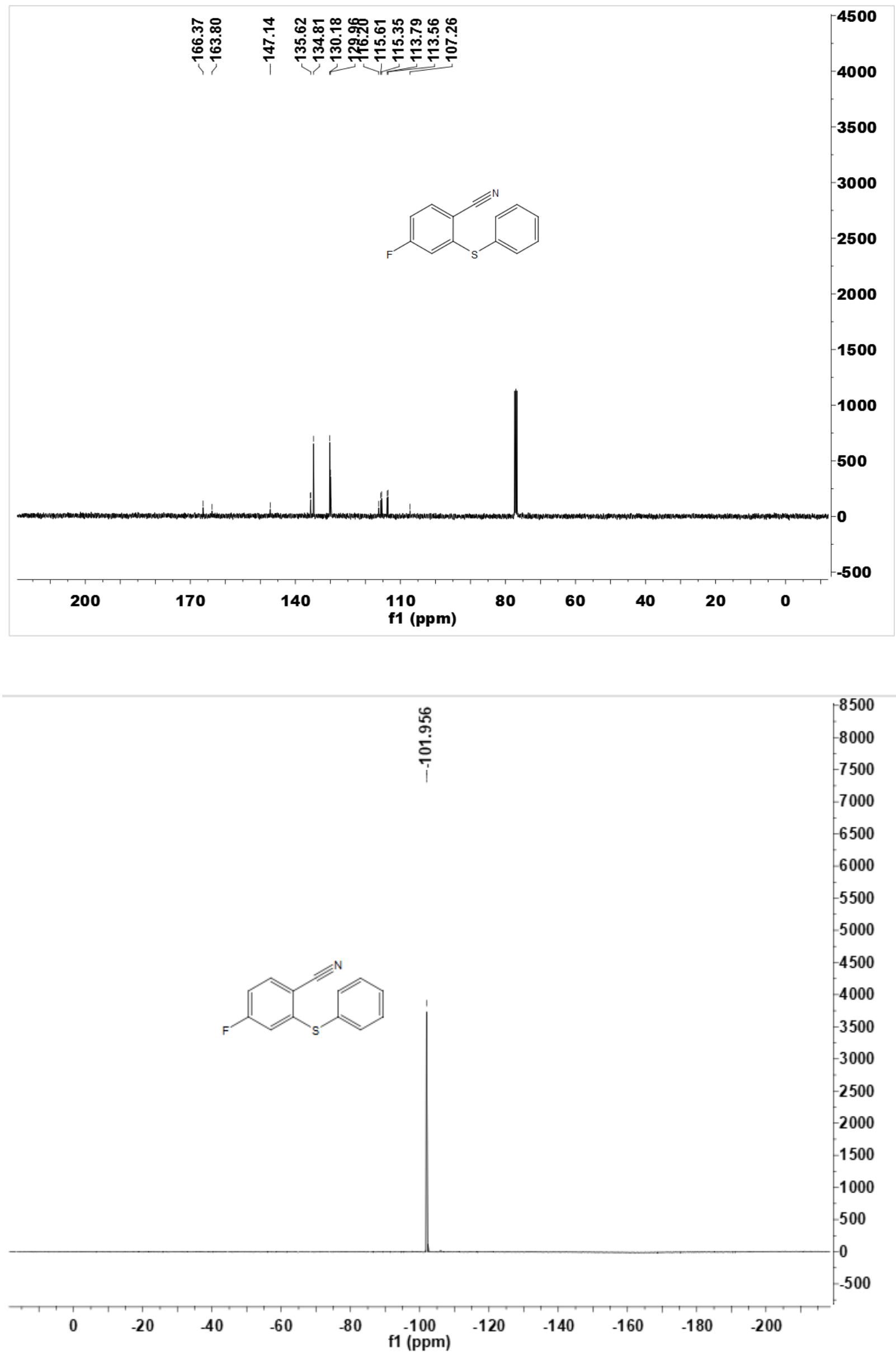
4-Chloro-2-(phenylthio)benzonitrile (8c)
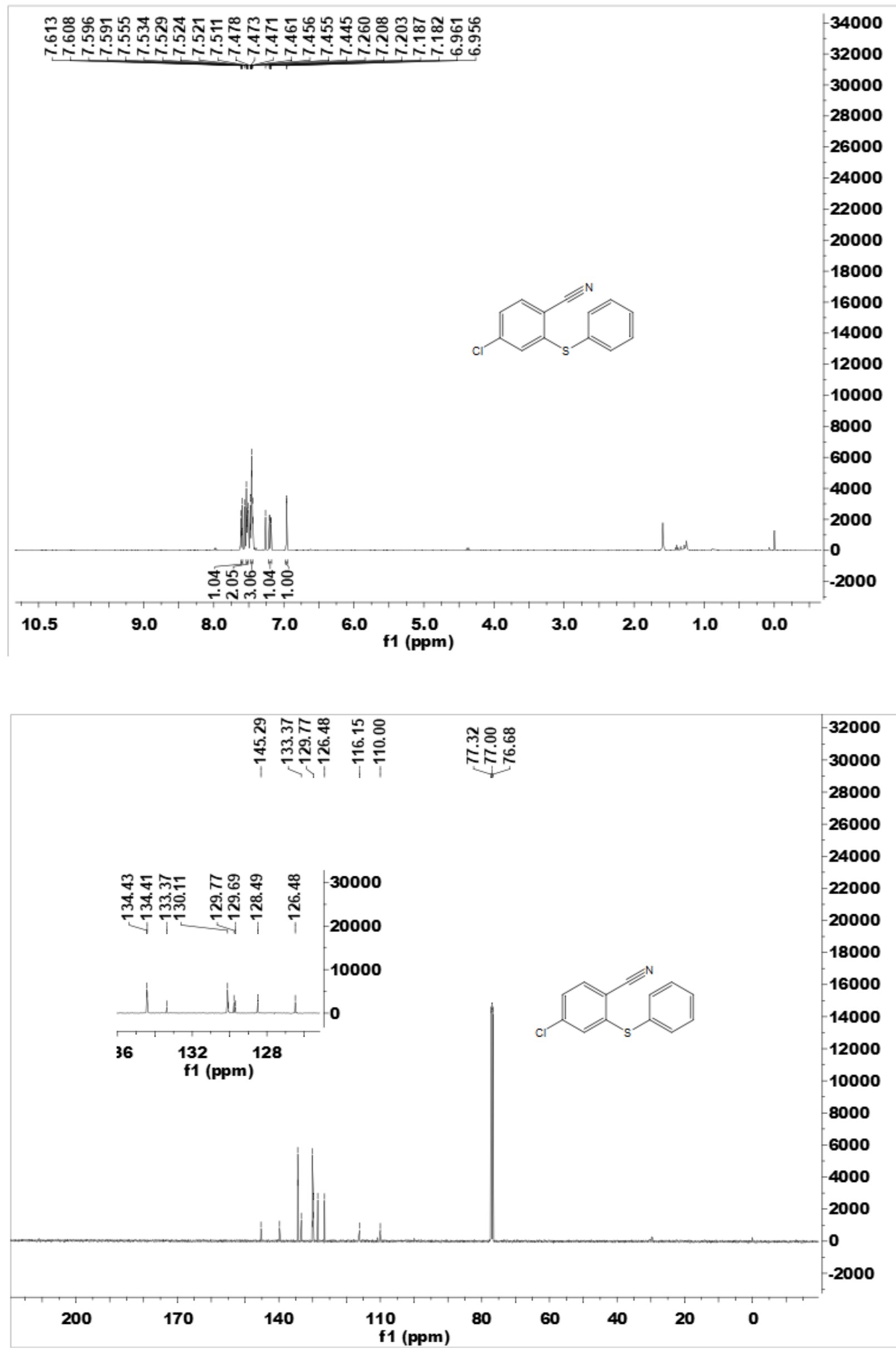
4-Bromo-2-(phenylthio)benzonitrile (8d)
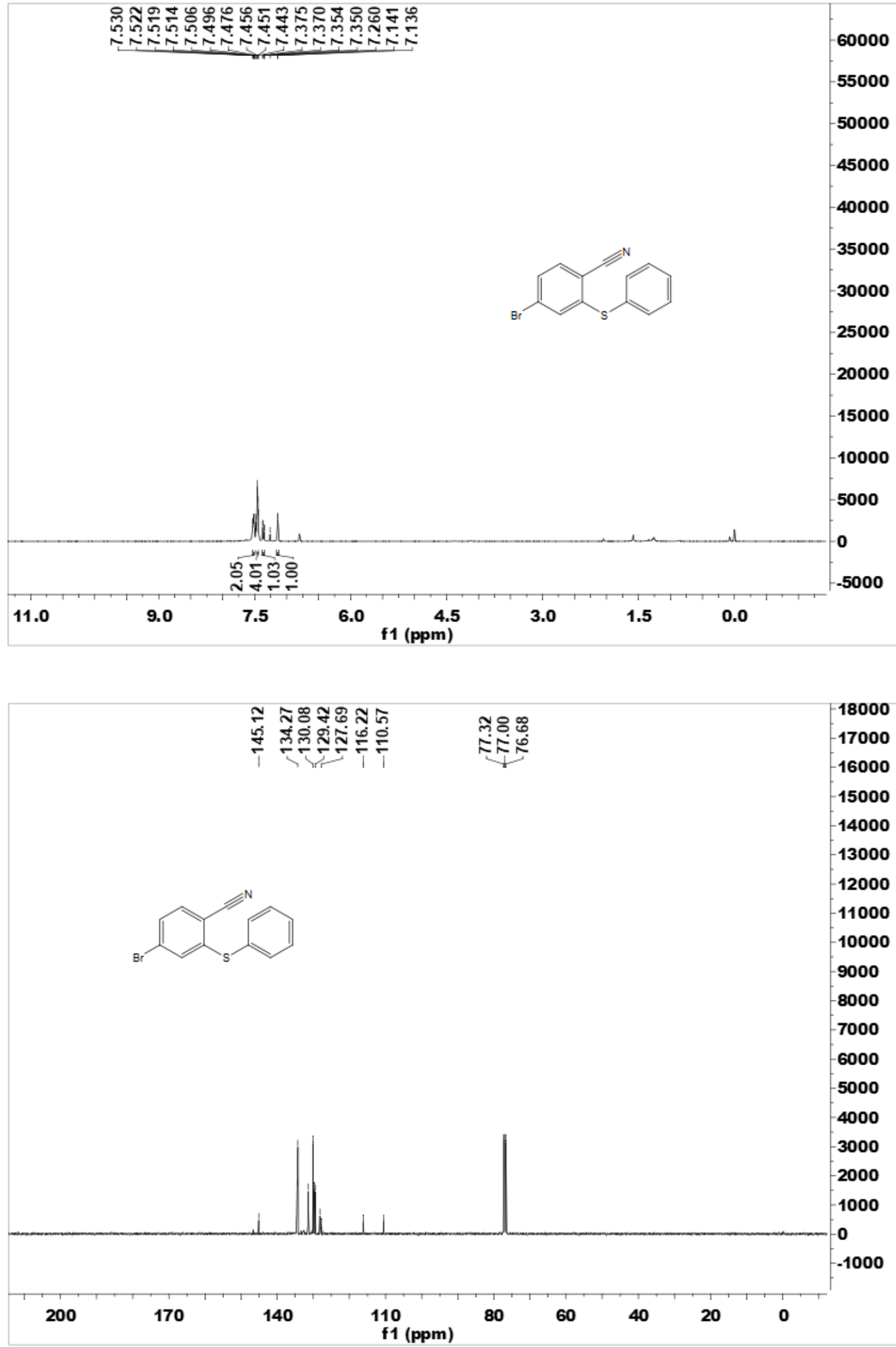
4-Iodo-2-(phenylthio)benzonitrile (8e)
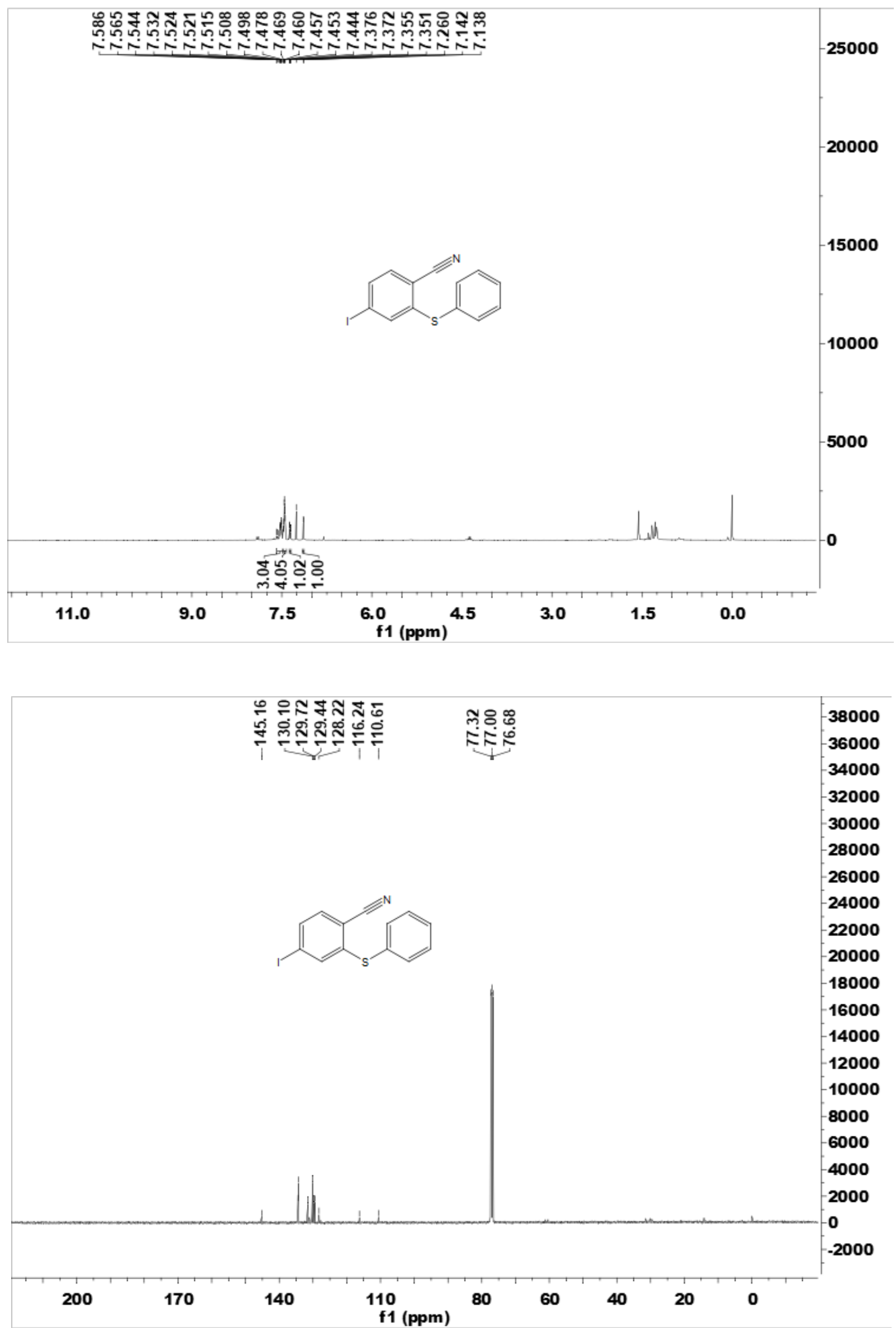
2-(Phenylthio)-4-(trifluoromethyl)benzonitrile (8f)
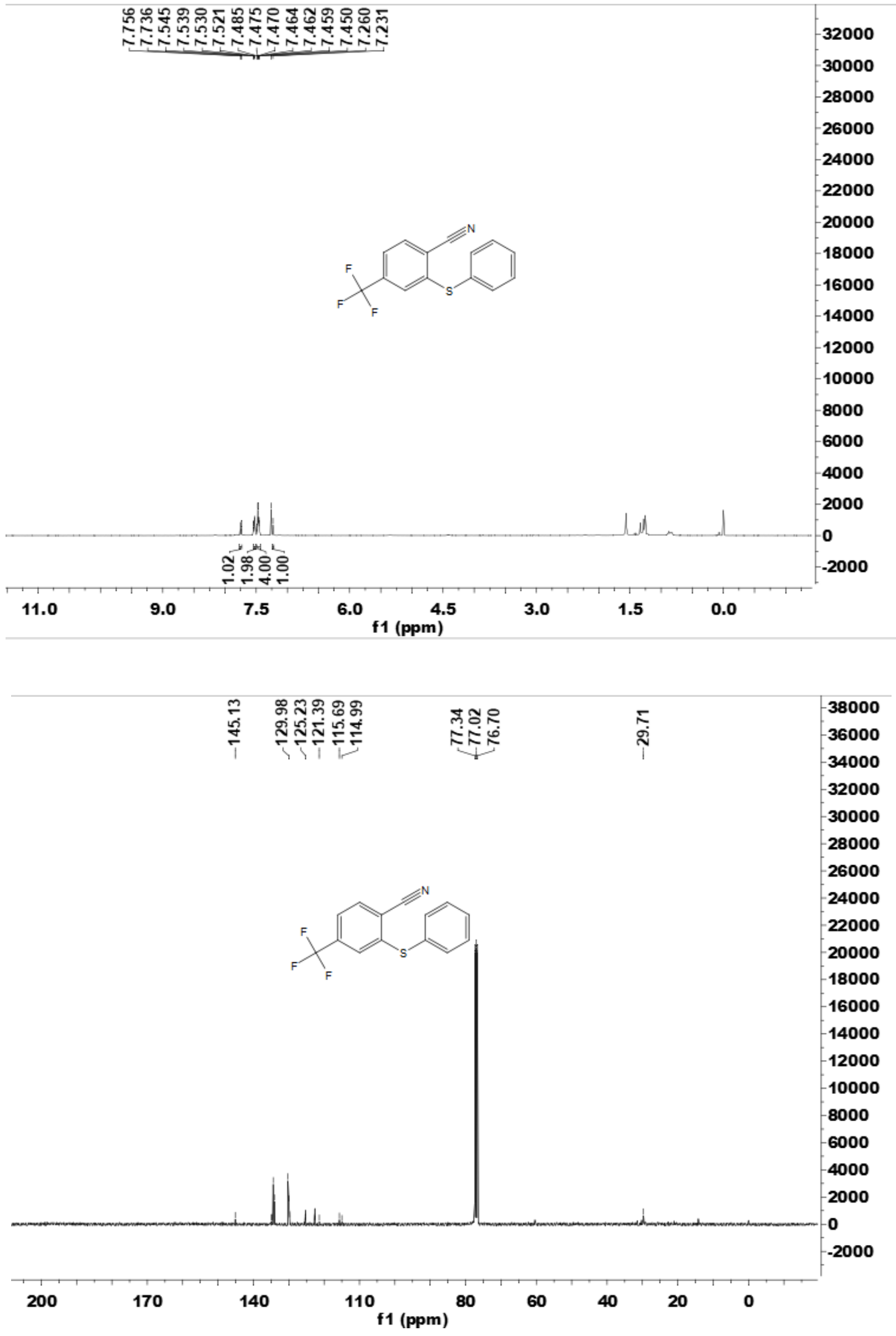


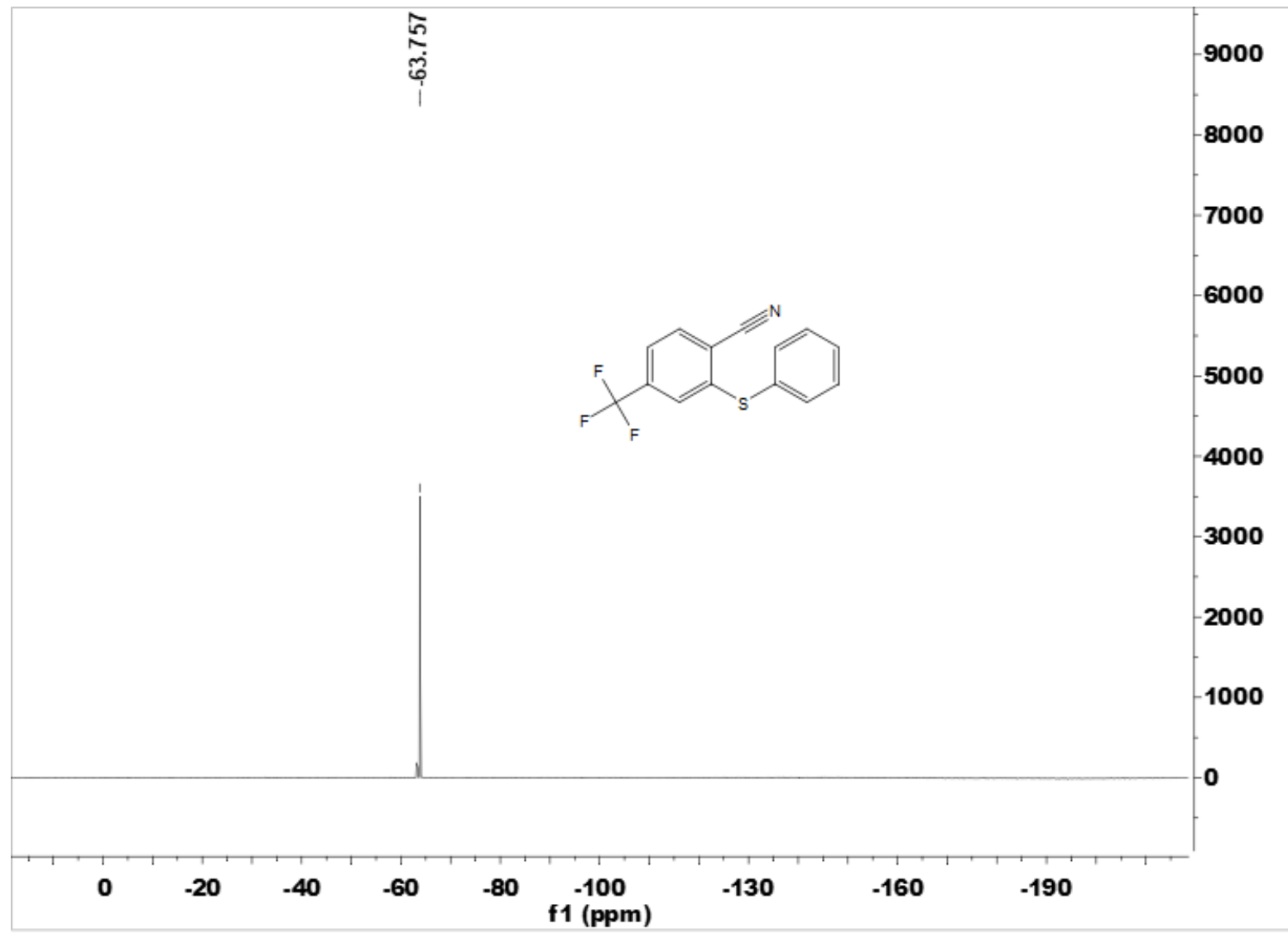

4-Nitro-2-(phenylthio)benzonitrile (8g)

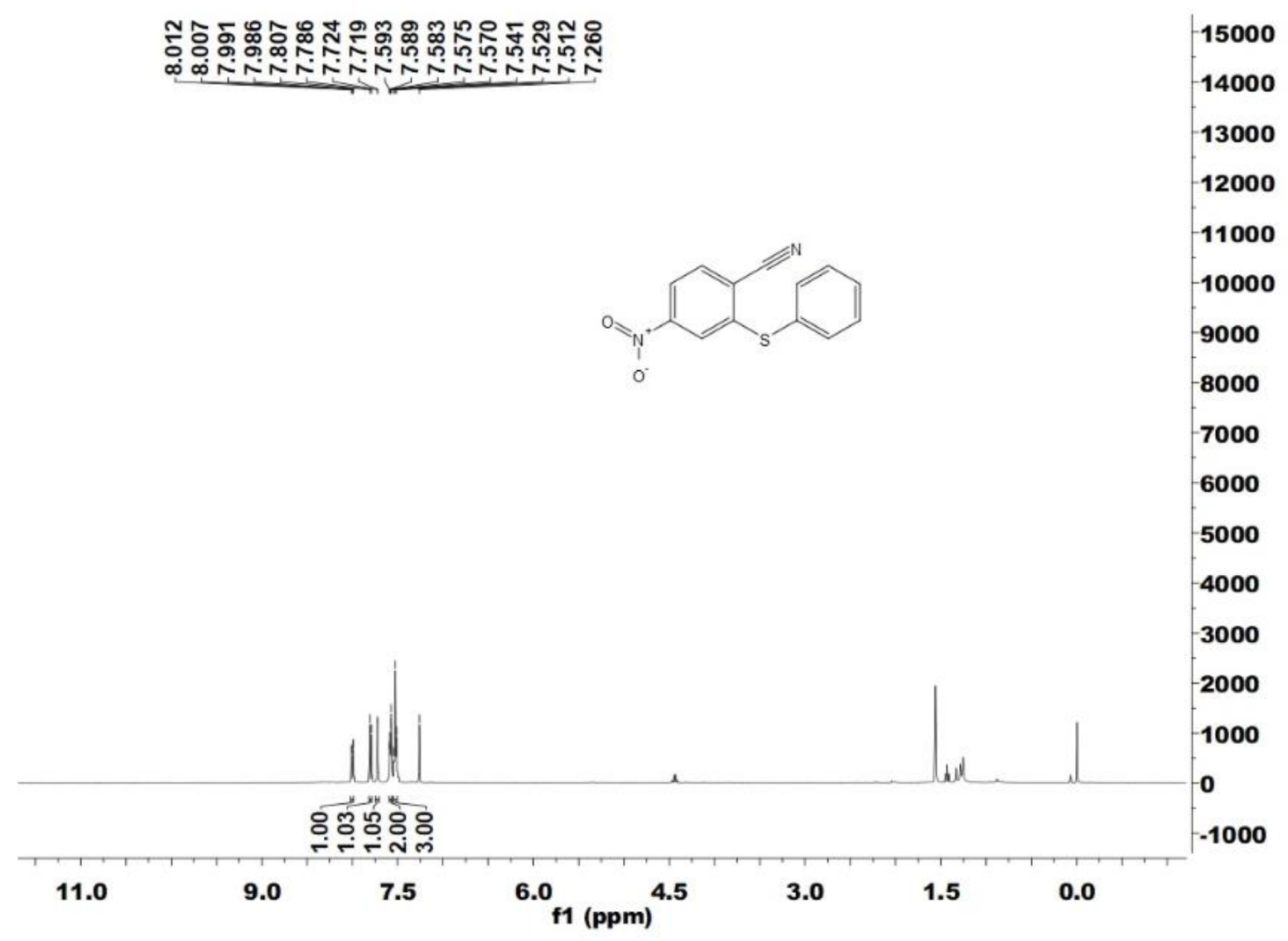




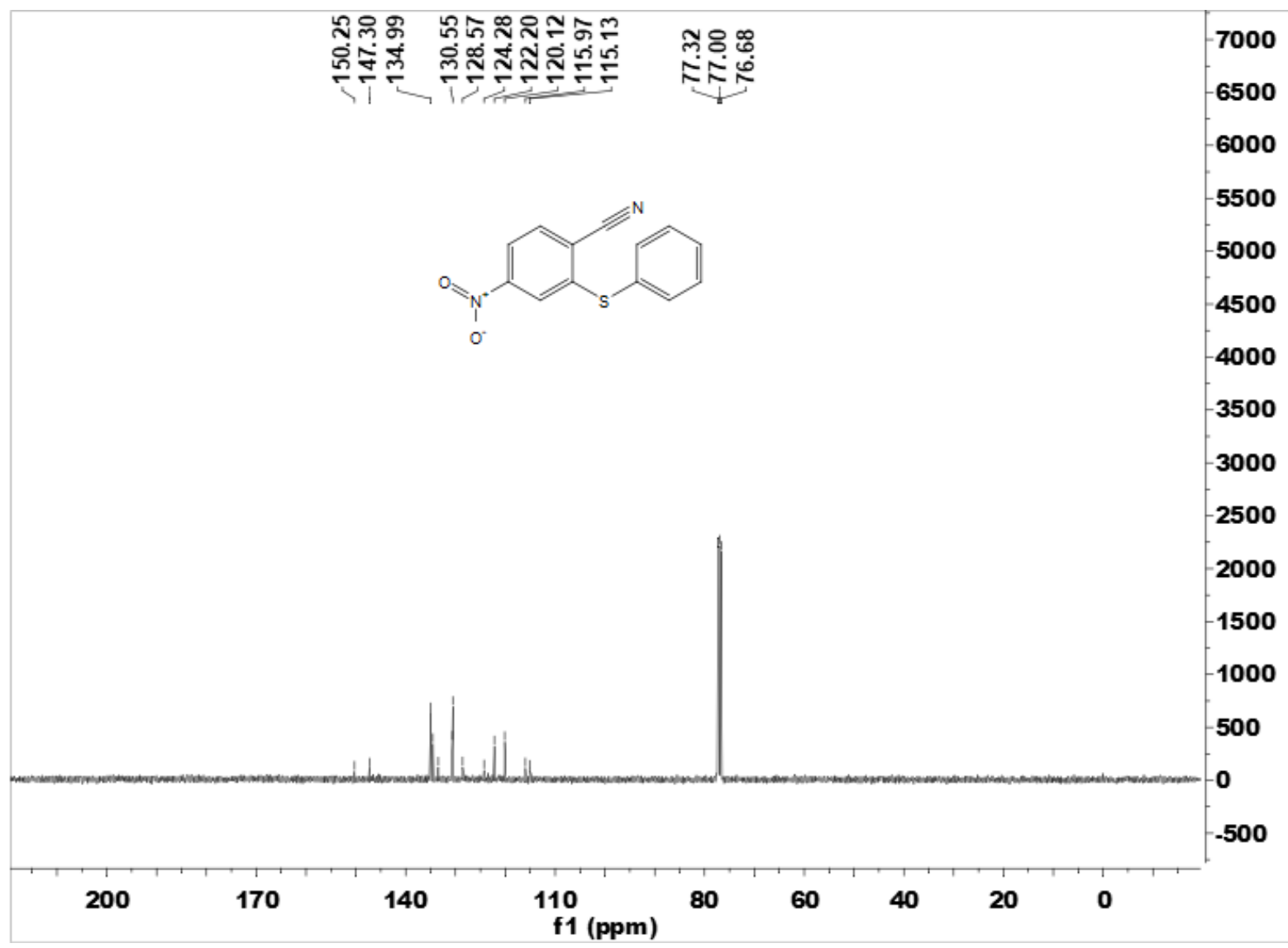

5-Methoxy-2-(phenylthio)benzonitrile (8h)

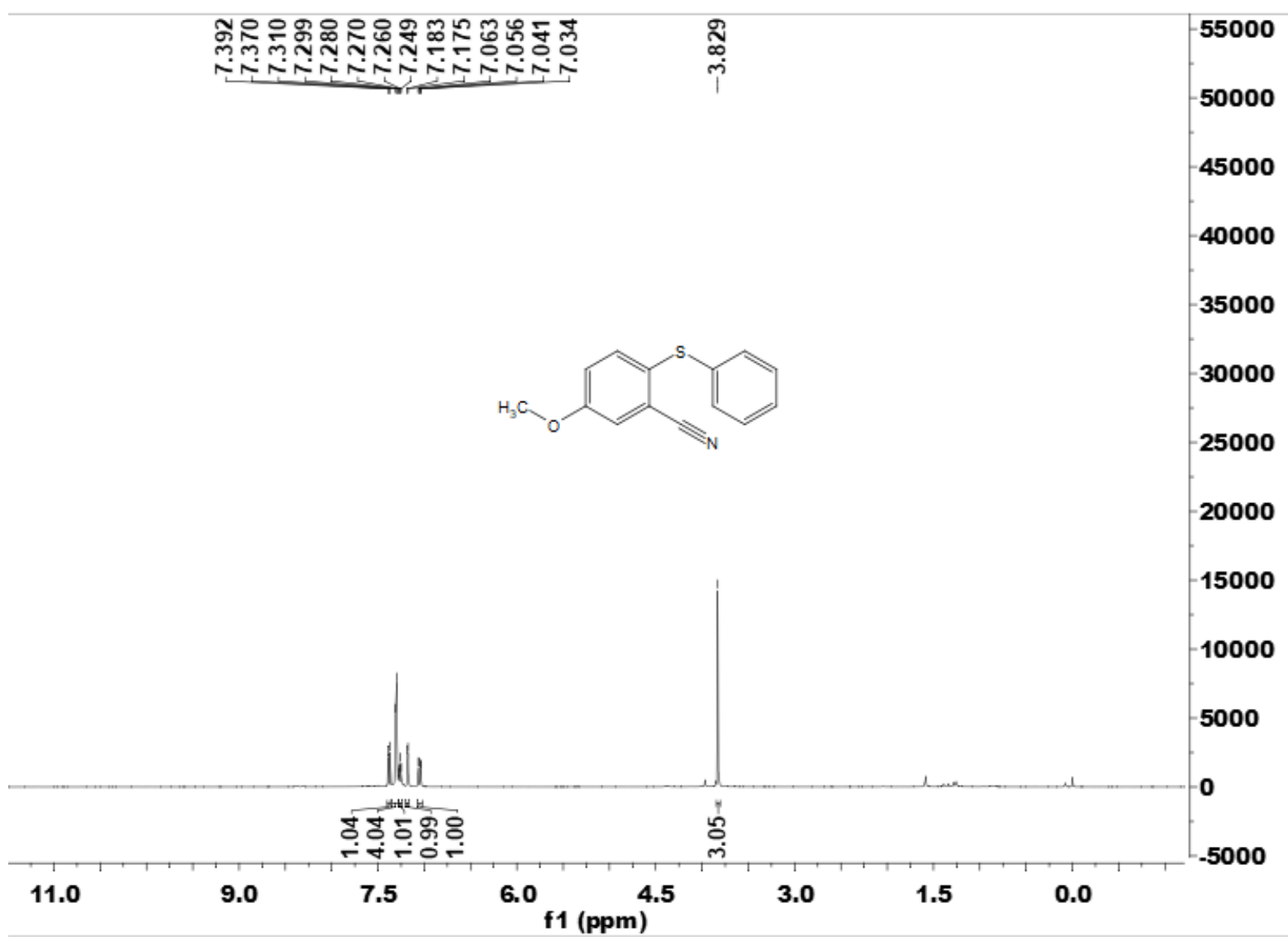




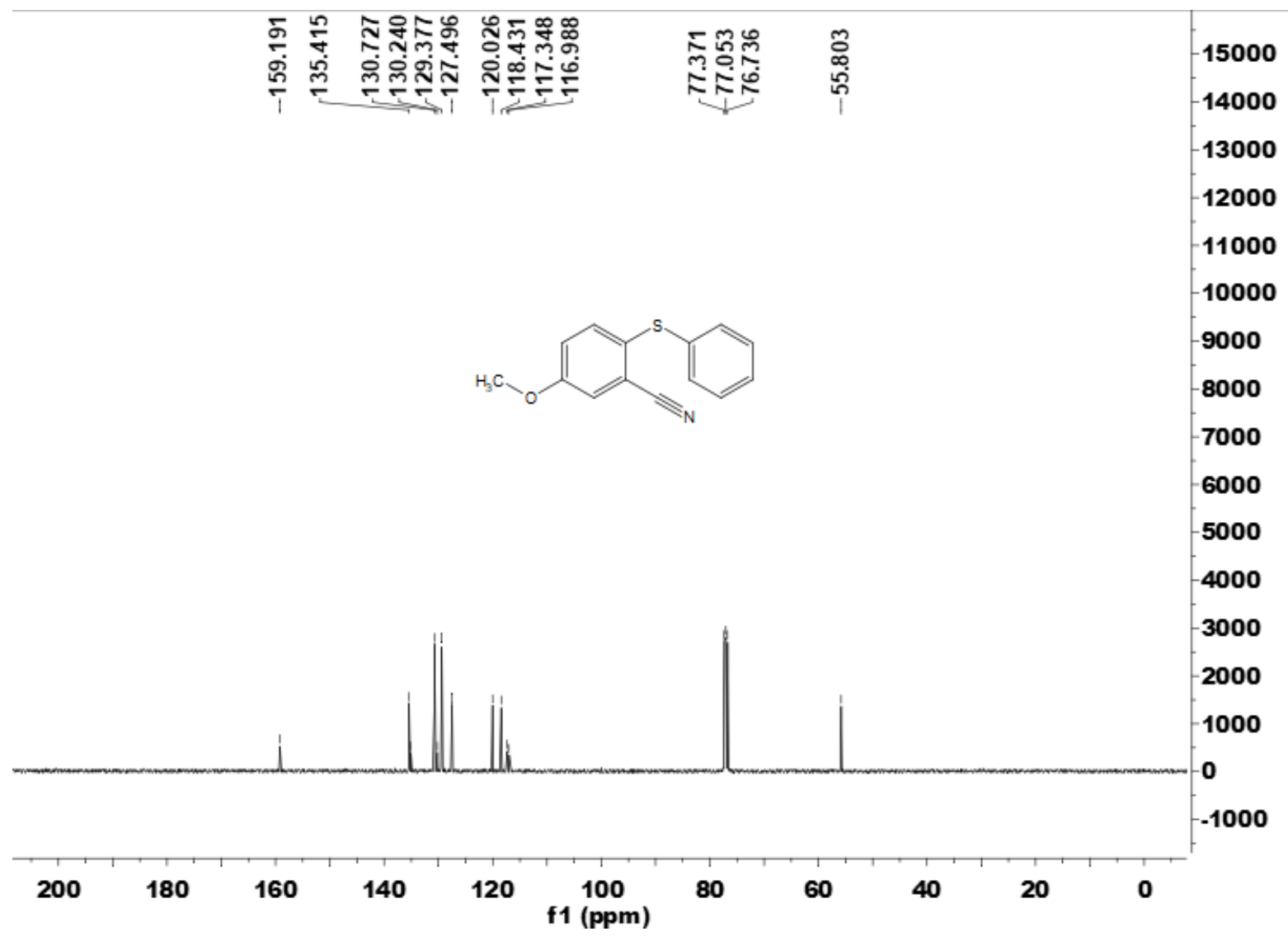

4-(Chloromethyl)-2-(phenylthio)benzonitrile (8i)

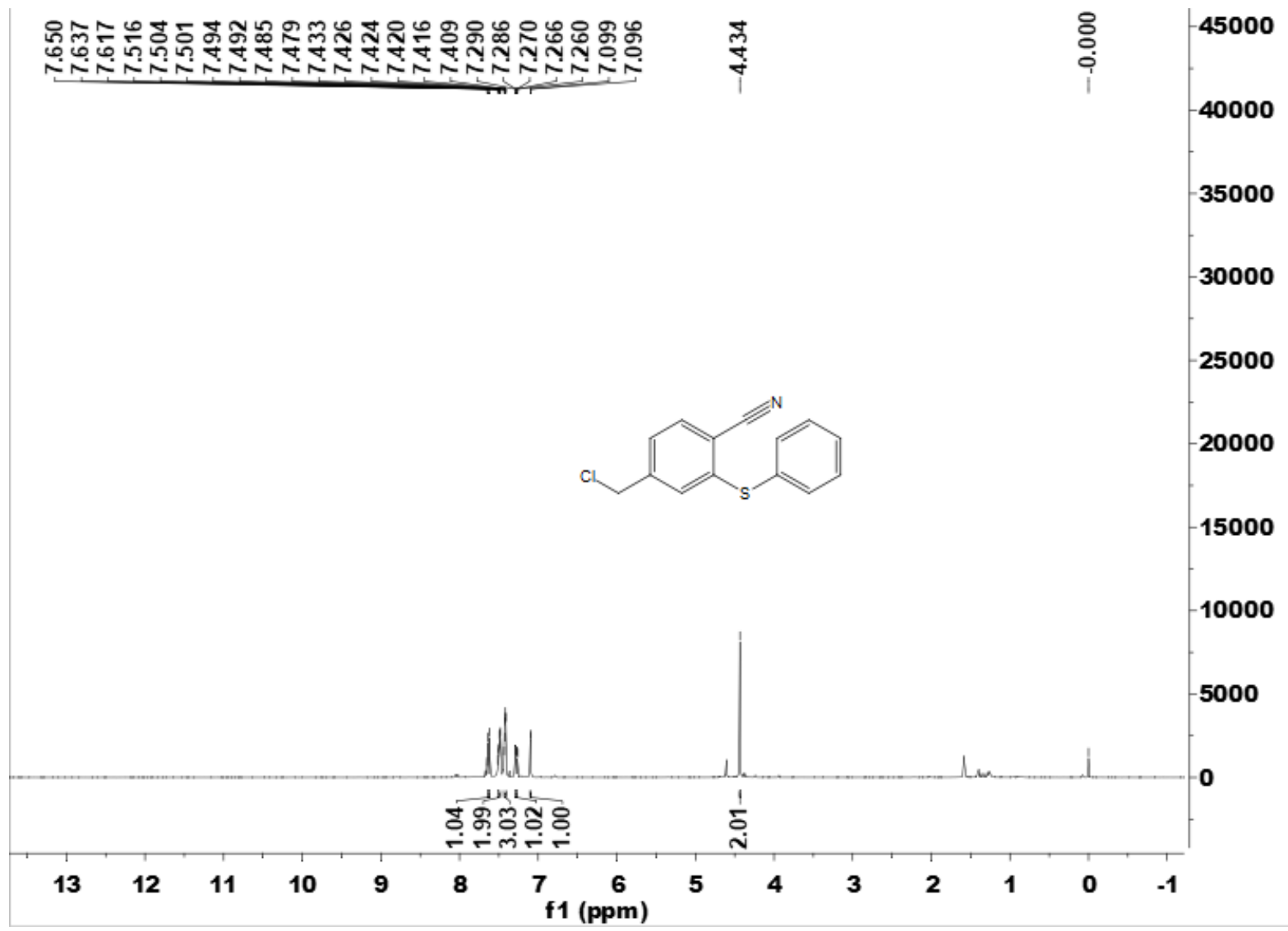




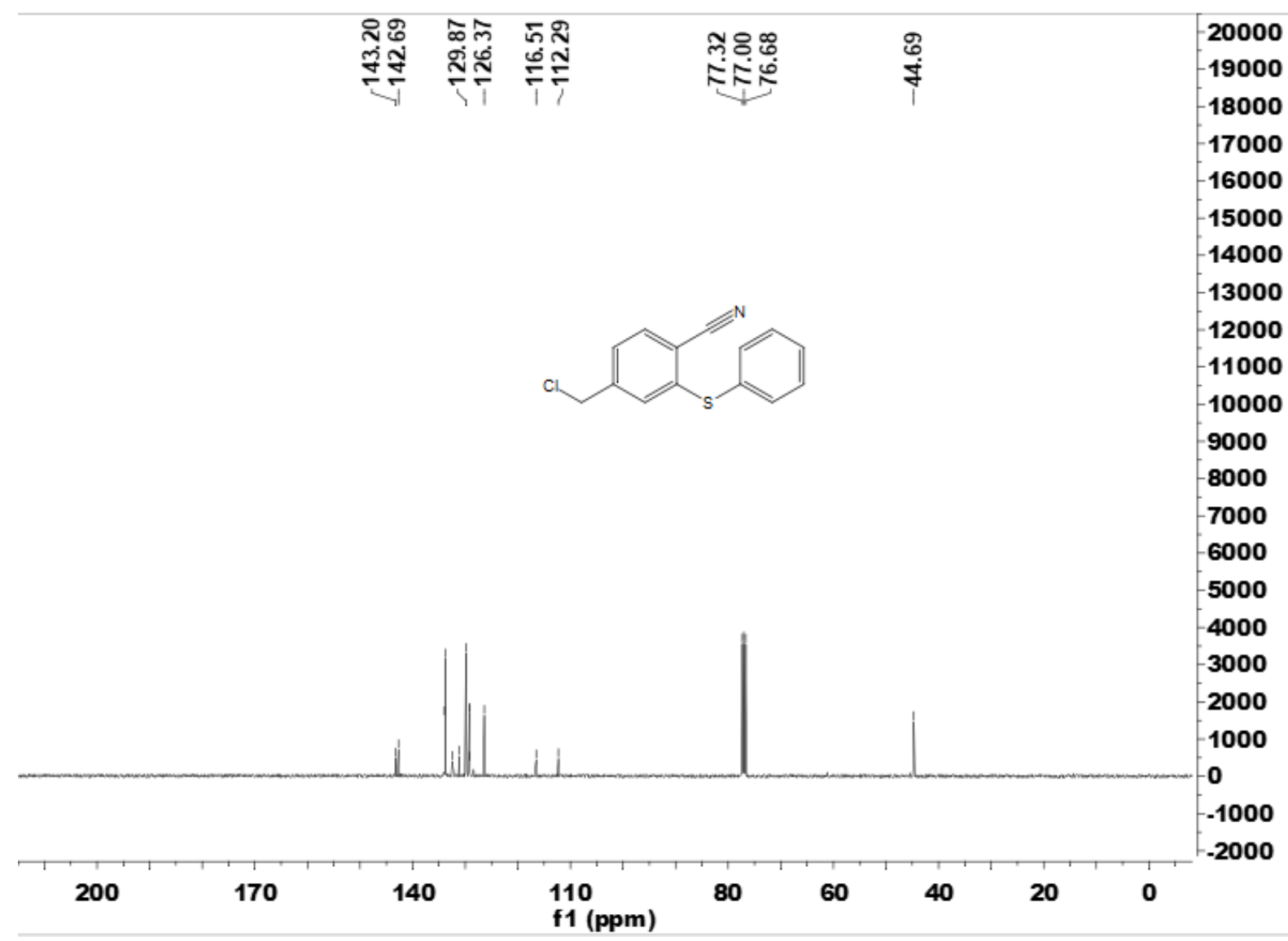

3-(Phenylthio)thiophene-2-carbonitrile (8j)

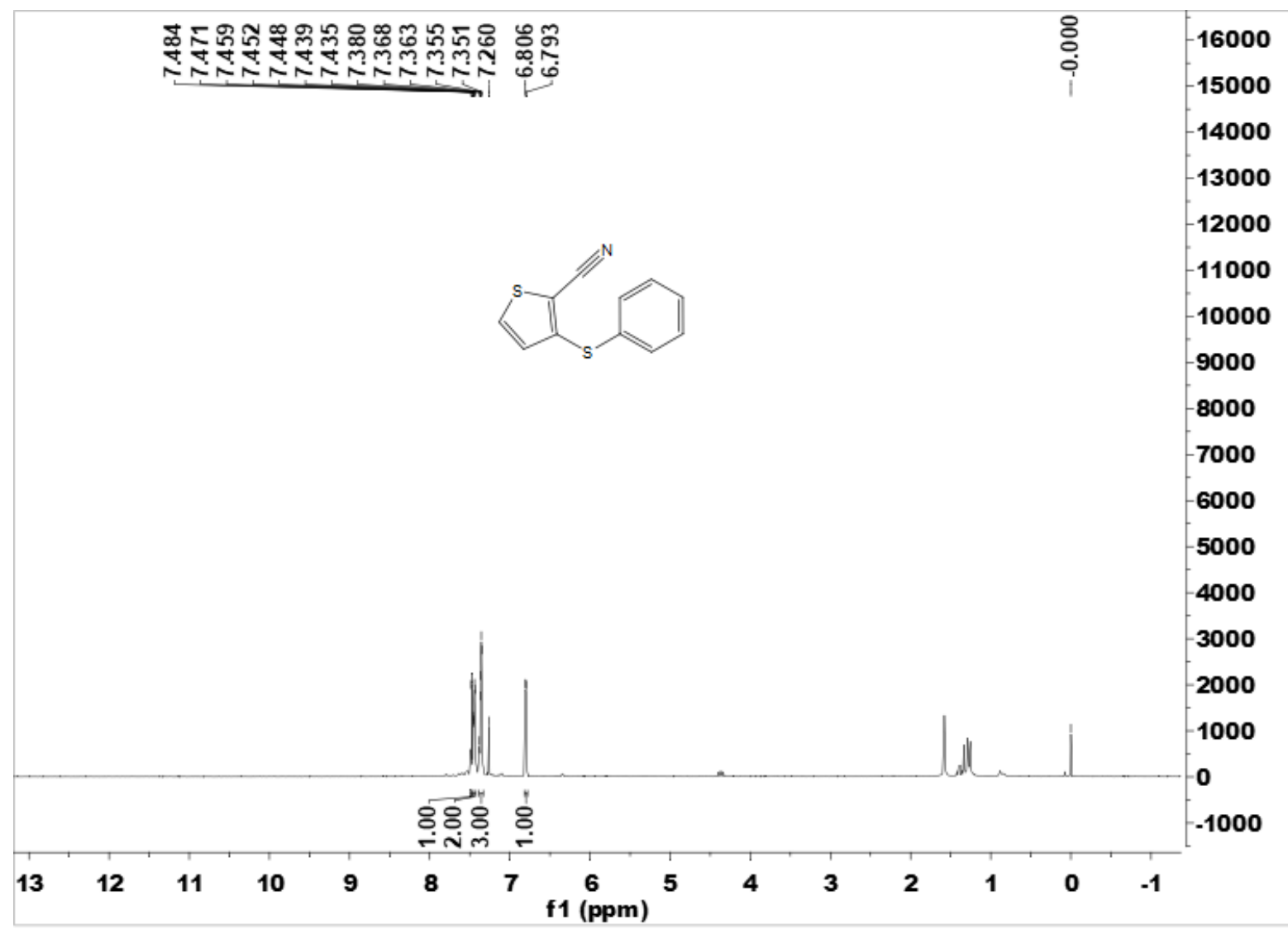




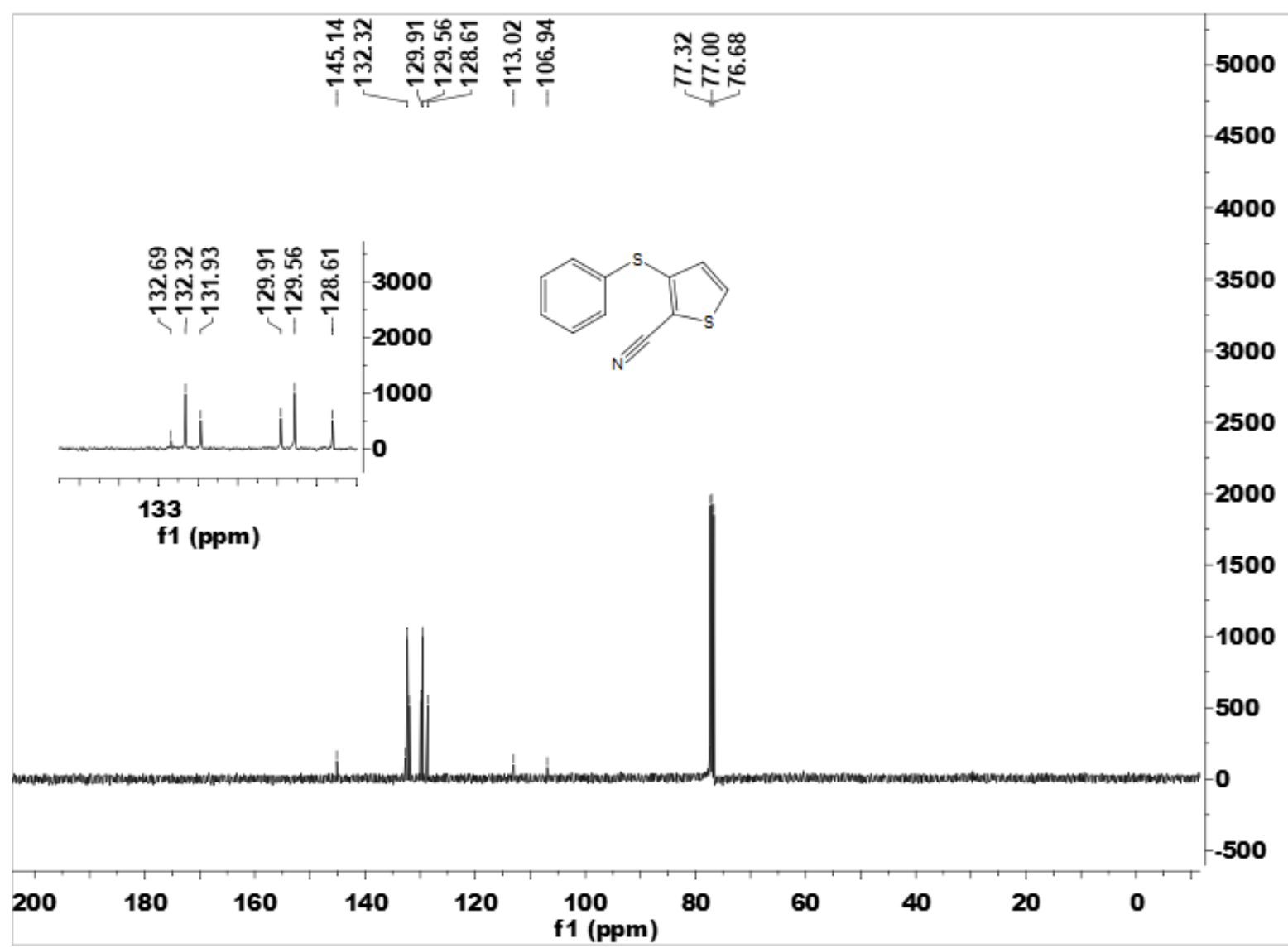

3-(Phenylthio)-2-naphthonitrile (8k)

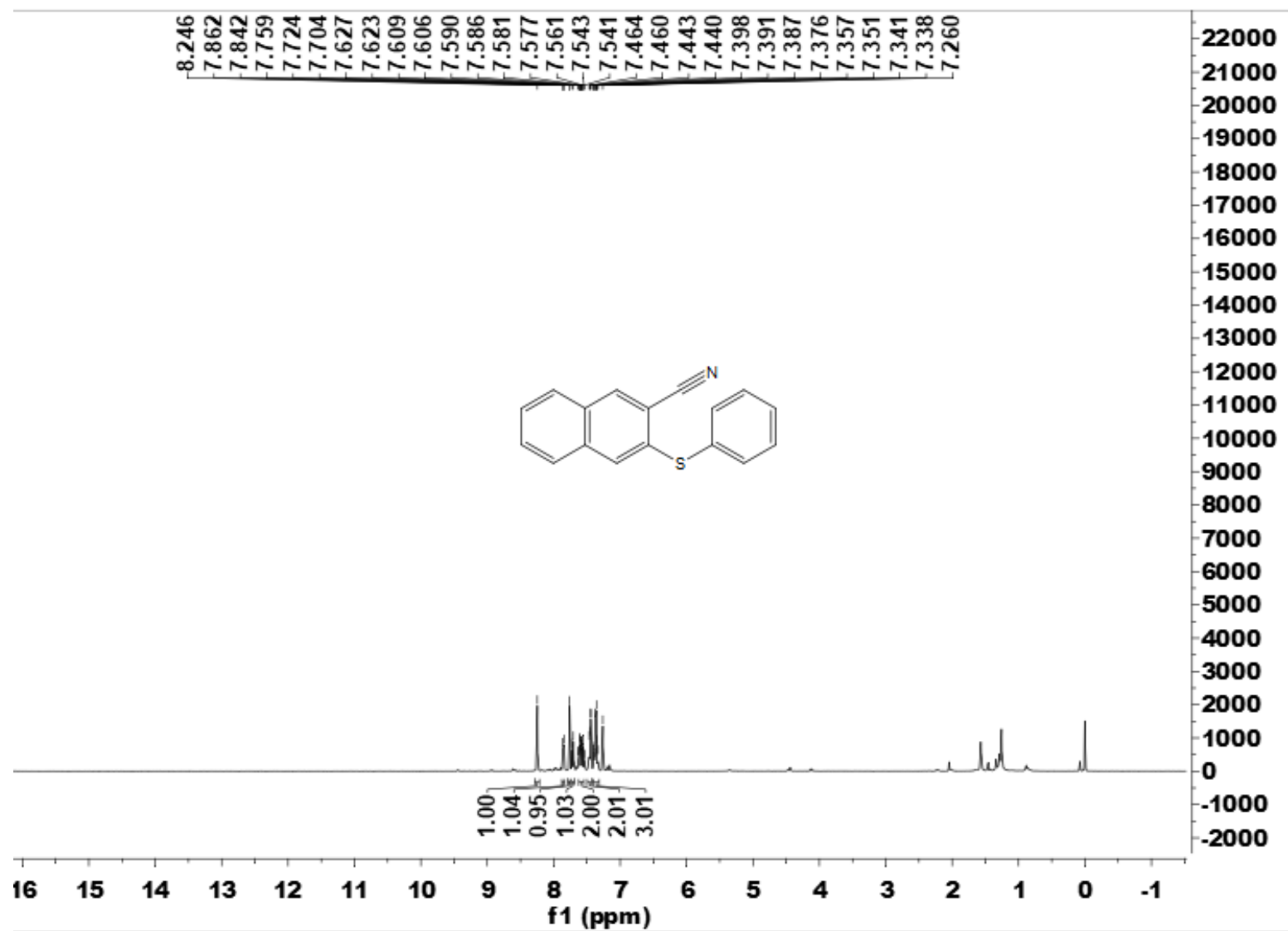




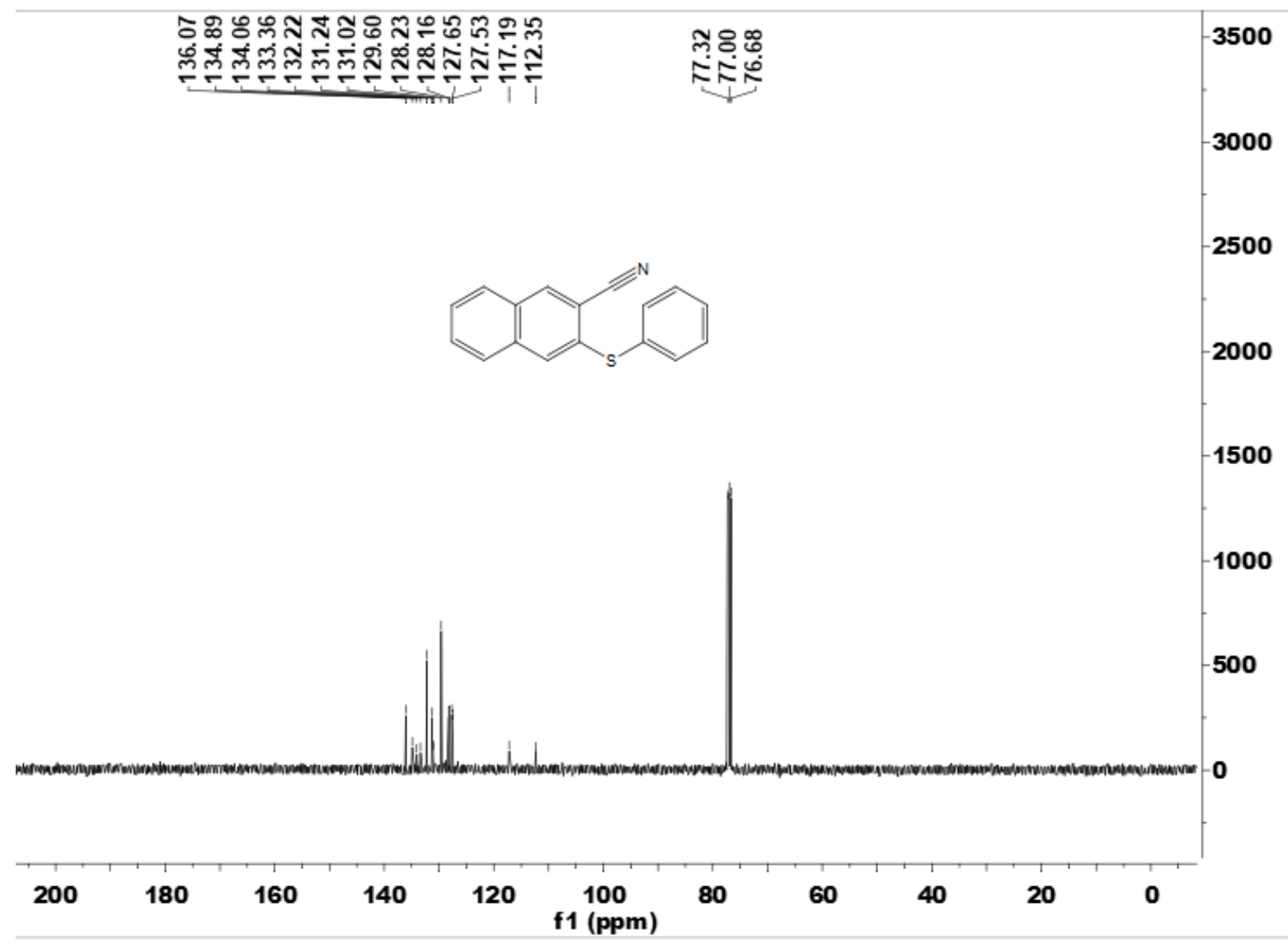

6-(Phenylthio)-1-tosyl-1H-indole-5-carbonitrile (81)

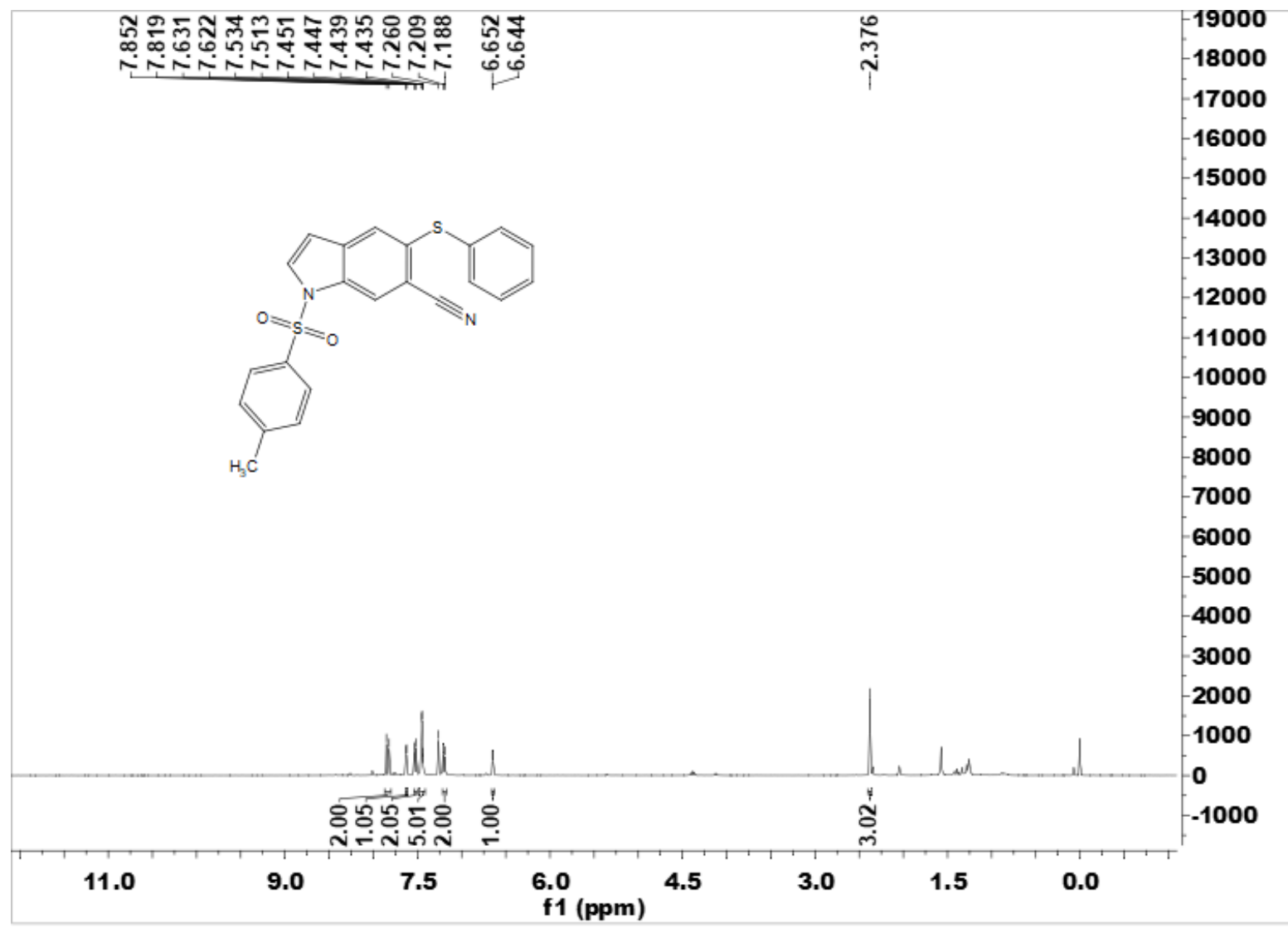




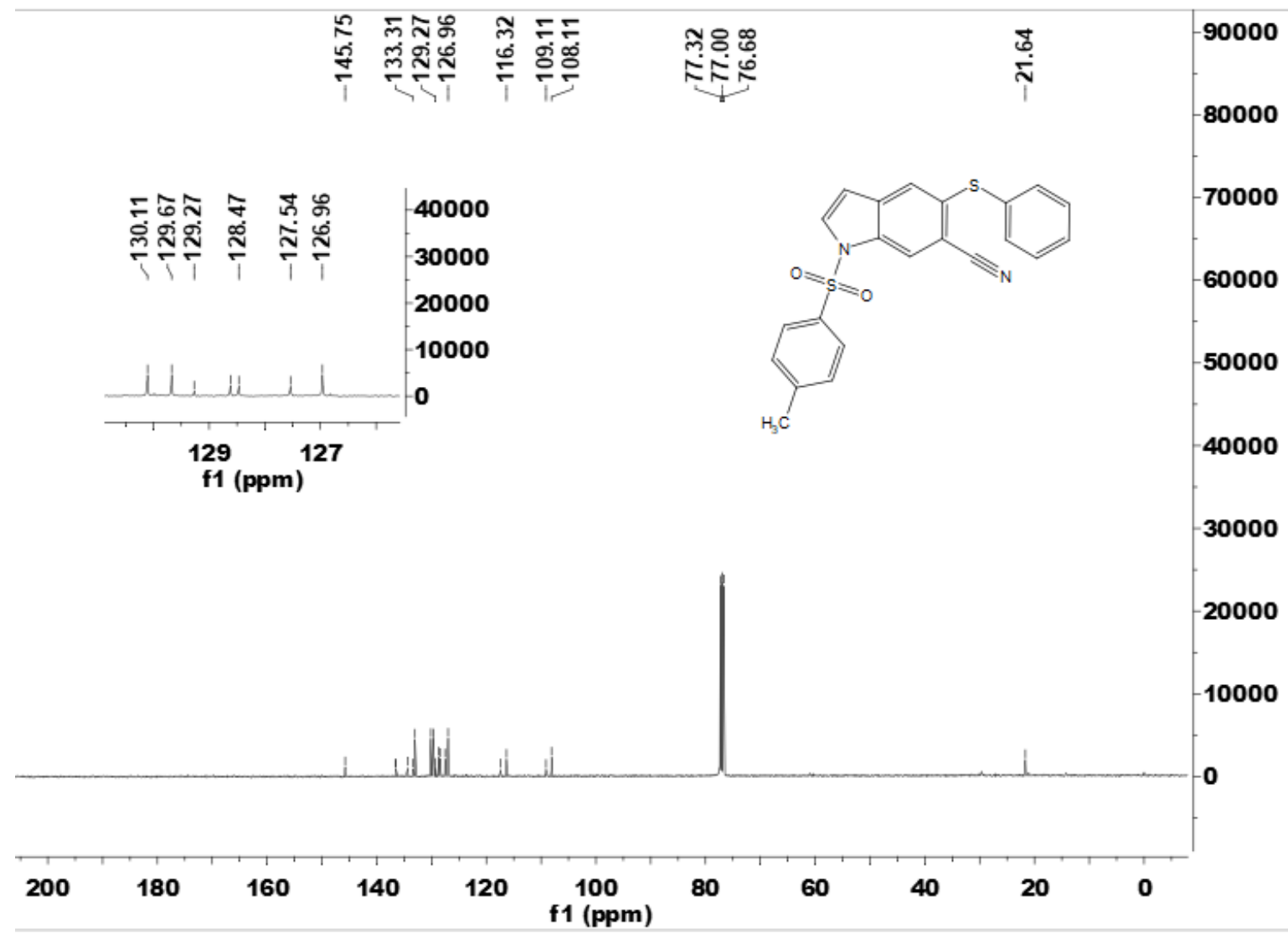

Methyl 2-((2-cyanophenyl)thio)benzoate (8m)

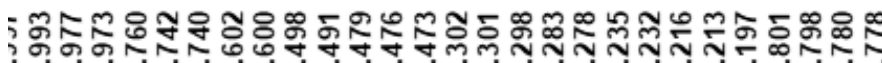

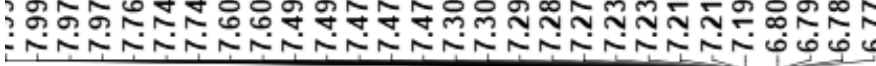

ฝึ

60000

$-55000$

$-50000$

45000
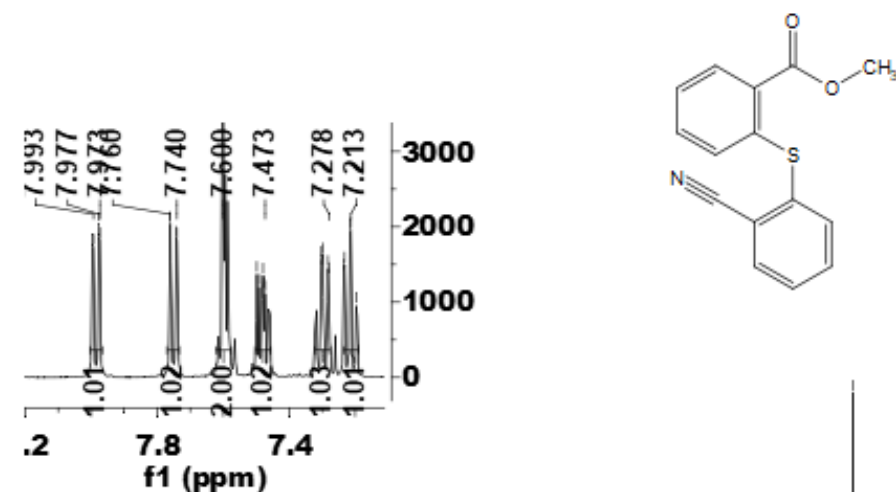

$-40000$

$-35000$

$-30000$

$-25000$

$-20000$

15000

10000

5000

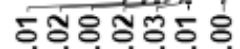

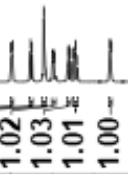

16

$\begin{array}{lllllllll}15 & 14 & 13 & 12 & 11 & 10 & 9 & 8 & 7\end{array}$

f1 (ppm) 


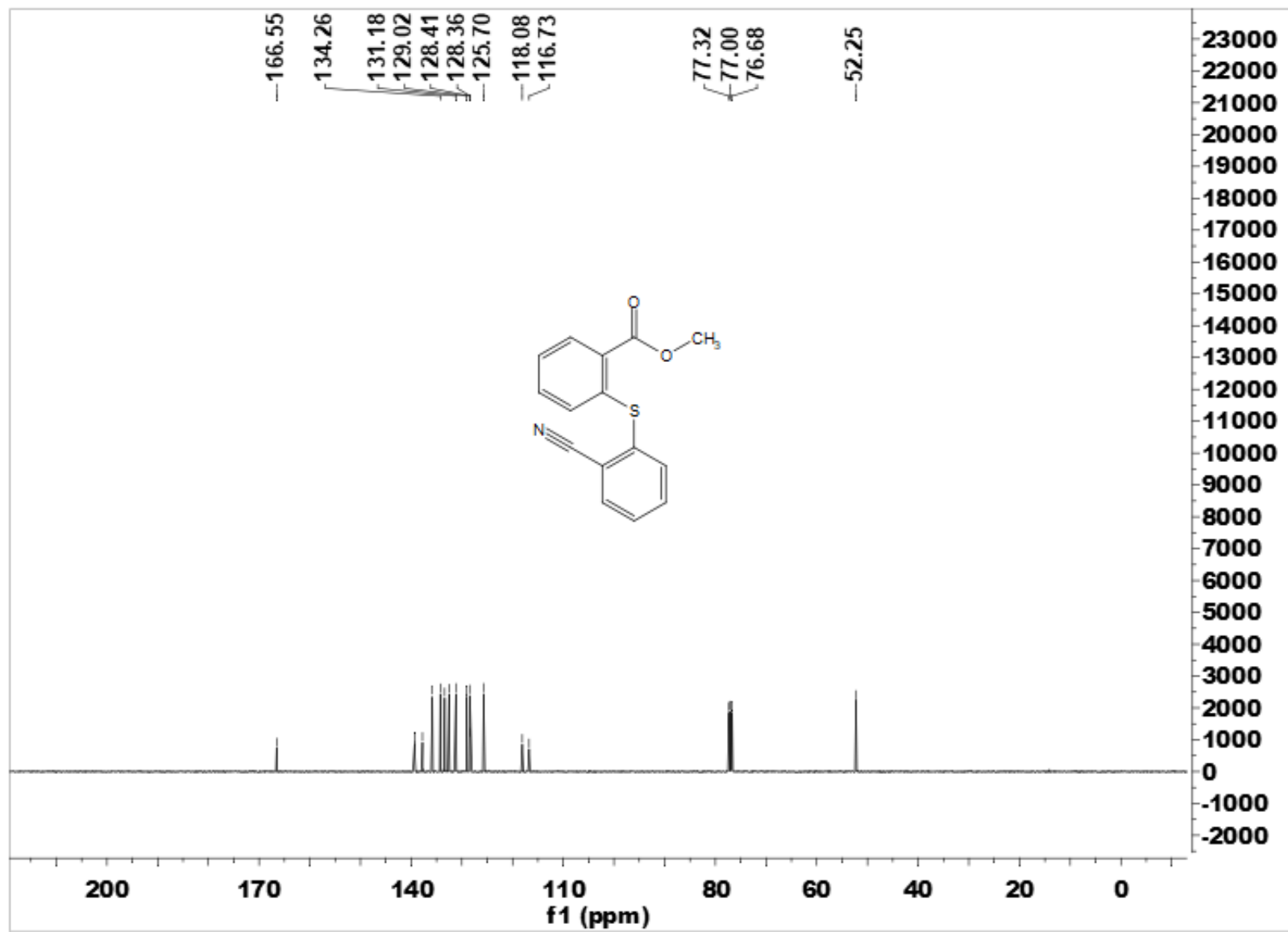

2-(p-Tolylthio)benzonitrile (8n)

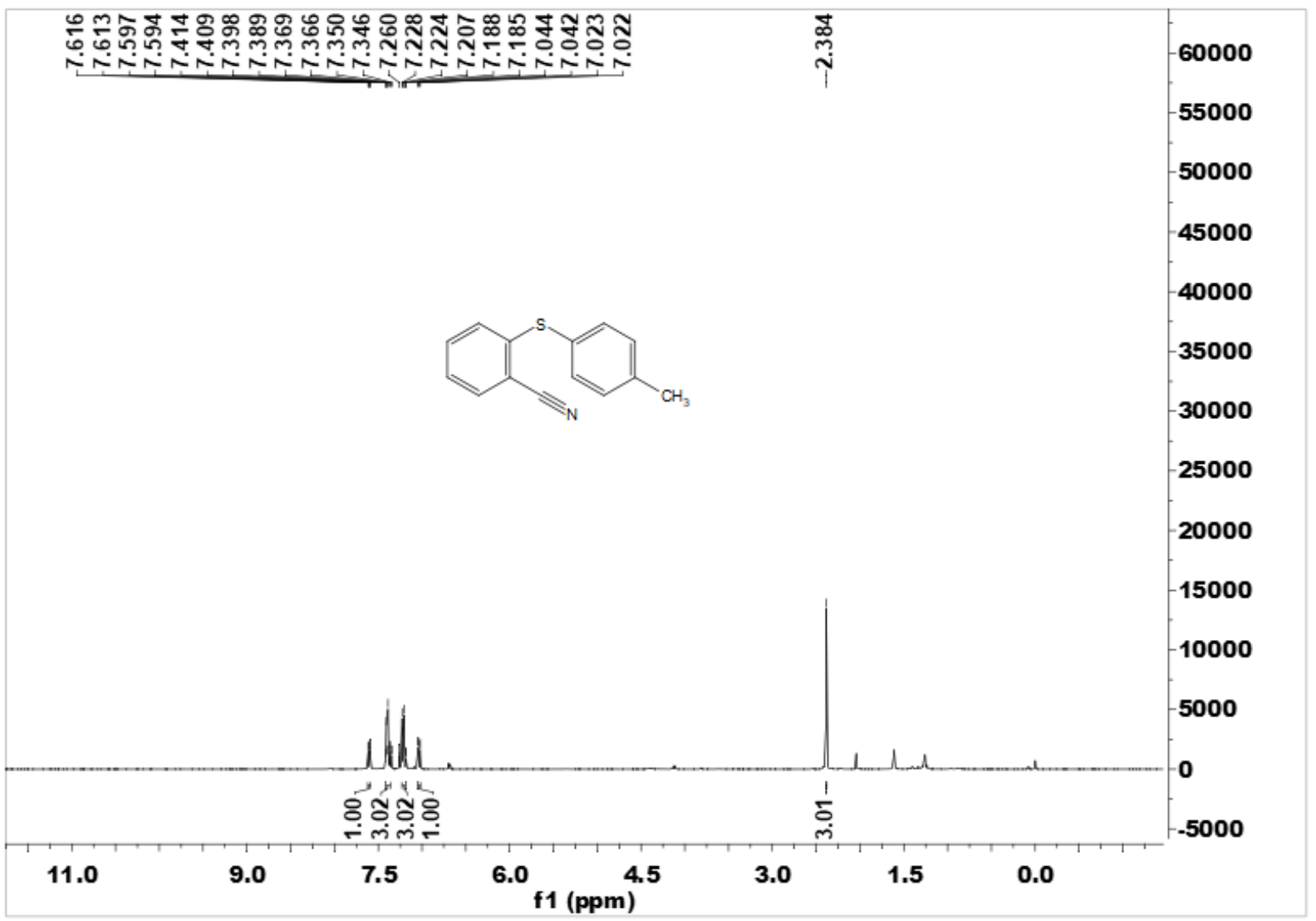




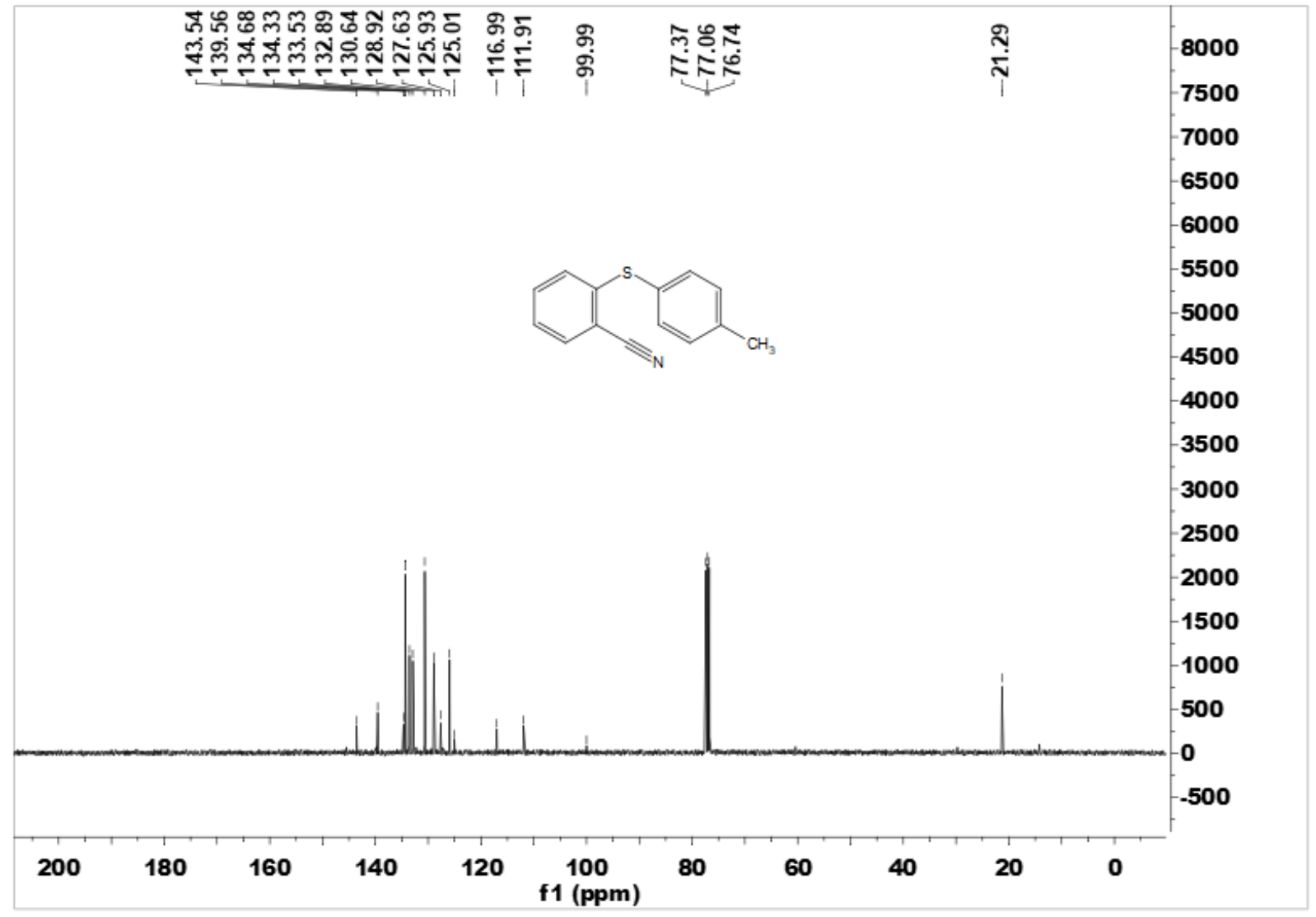

5-Methoxy-2-(phenylthio)benzonitrile (80)

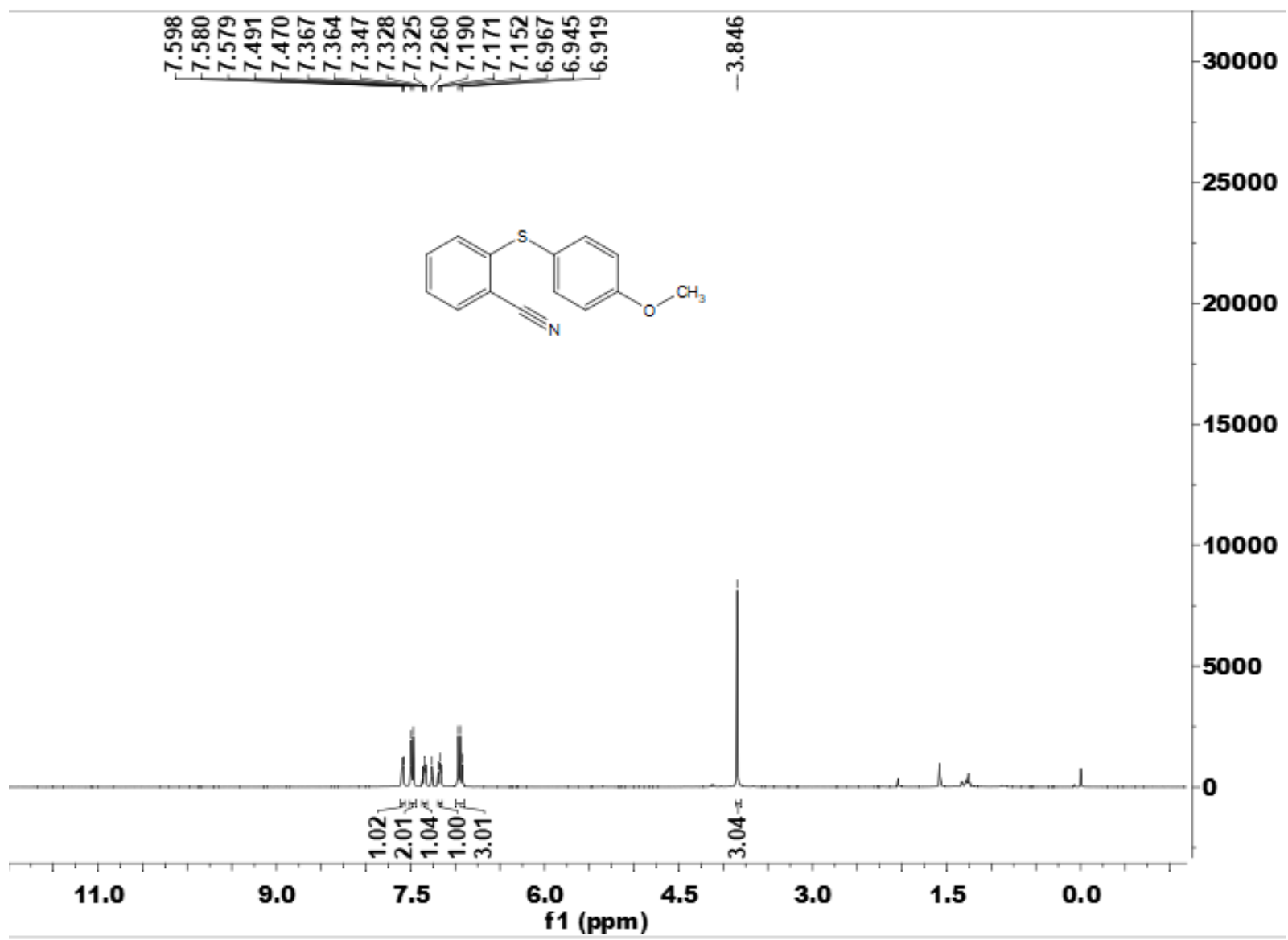




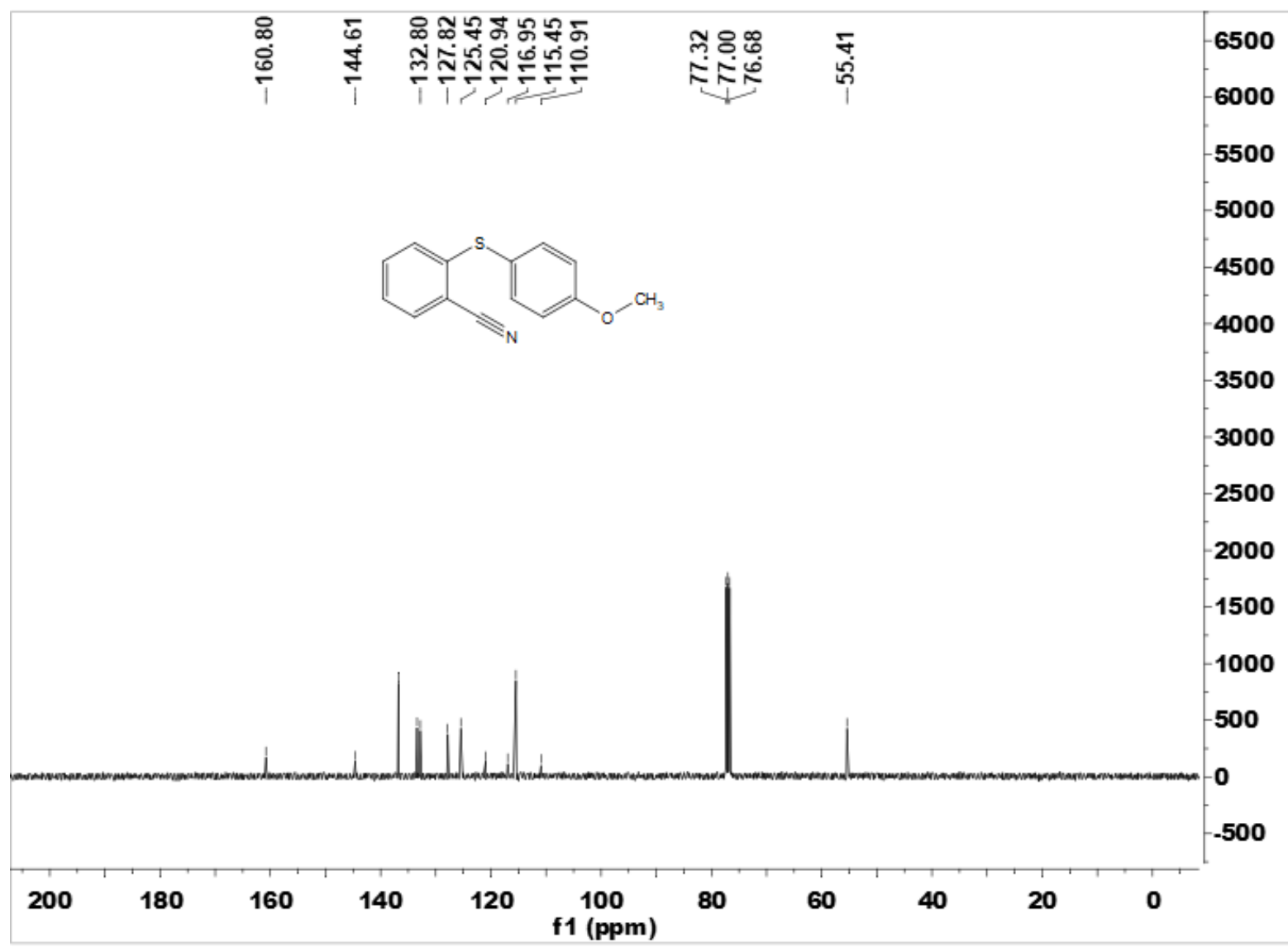

2-((4-Fluorophenyl)thio)benzonitrile (8p)

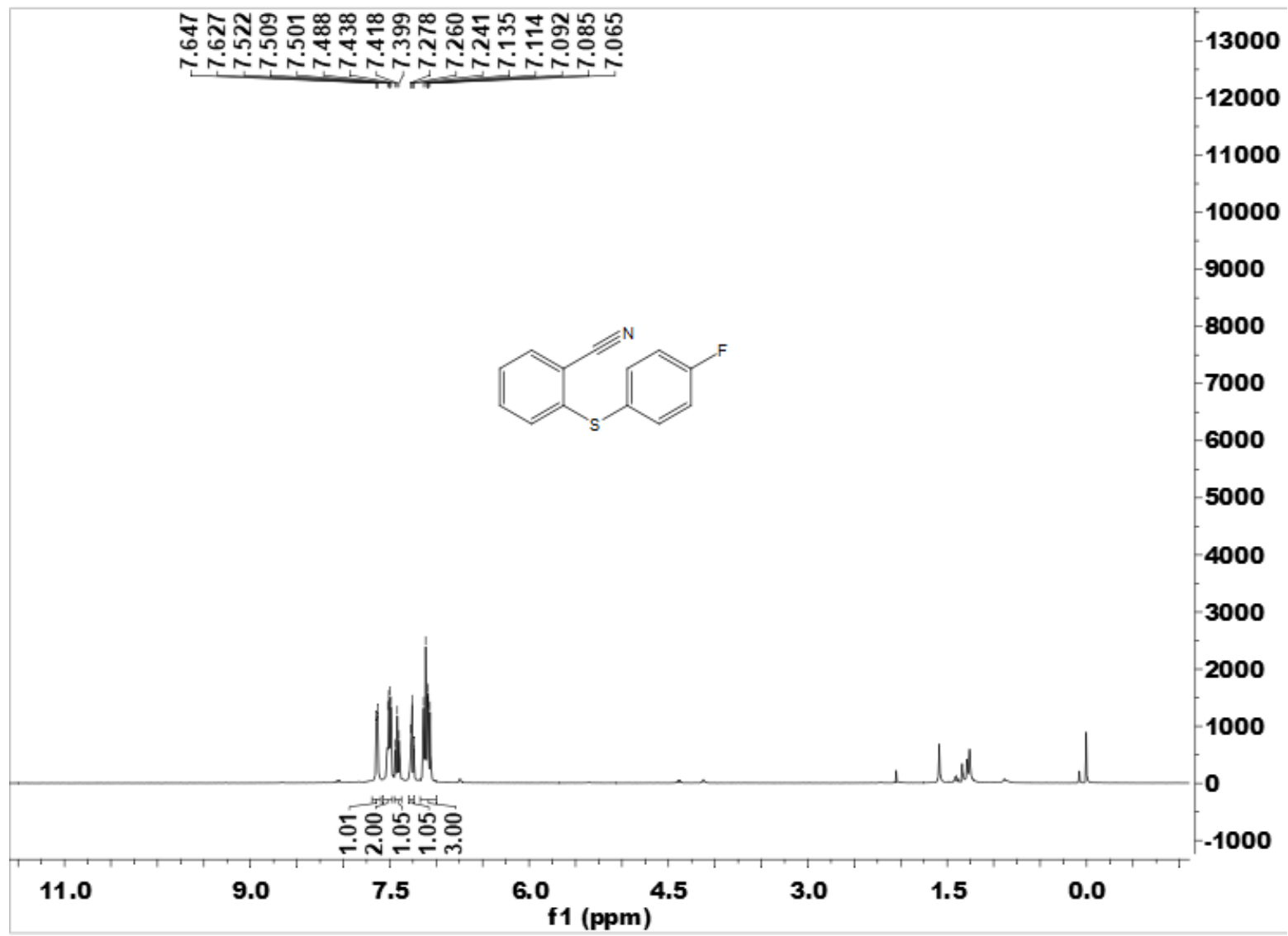



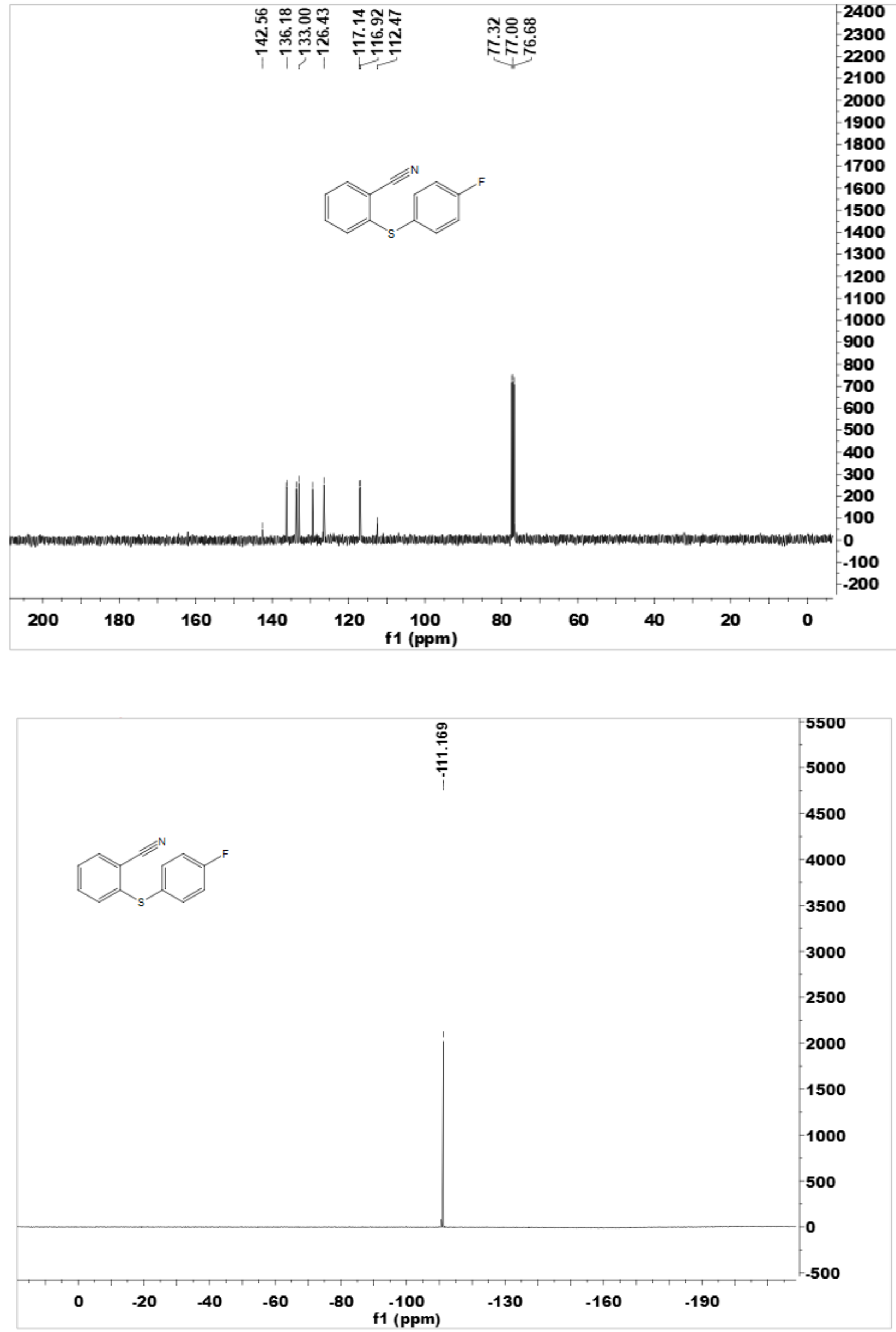
2-((4-Bromophenyl)thio)benzonitrile (8q)
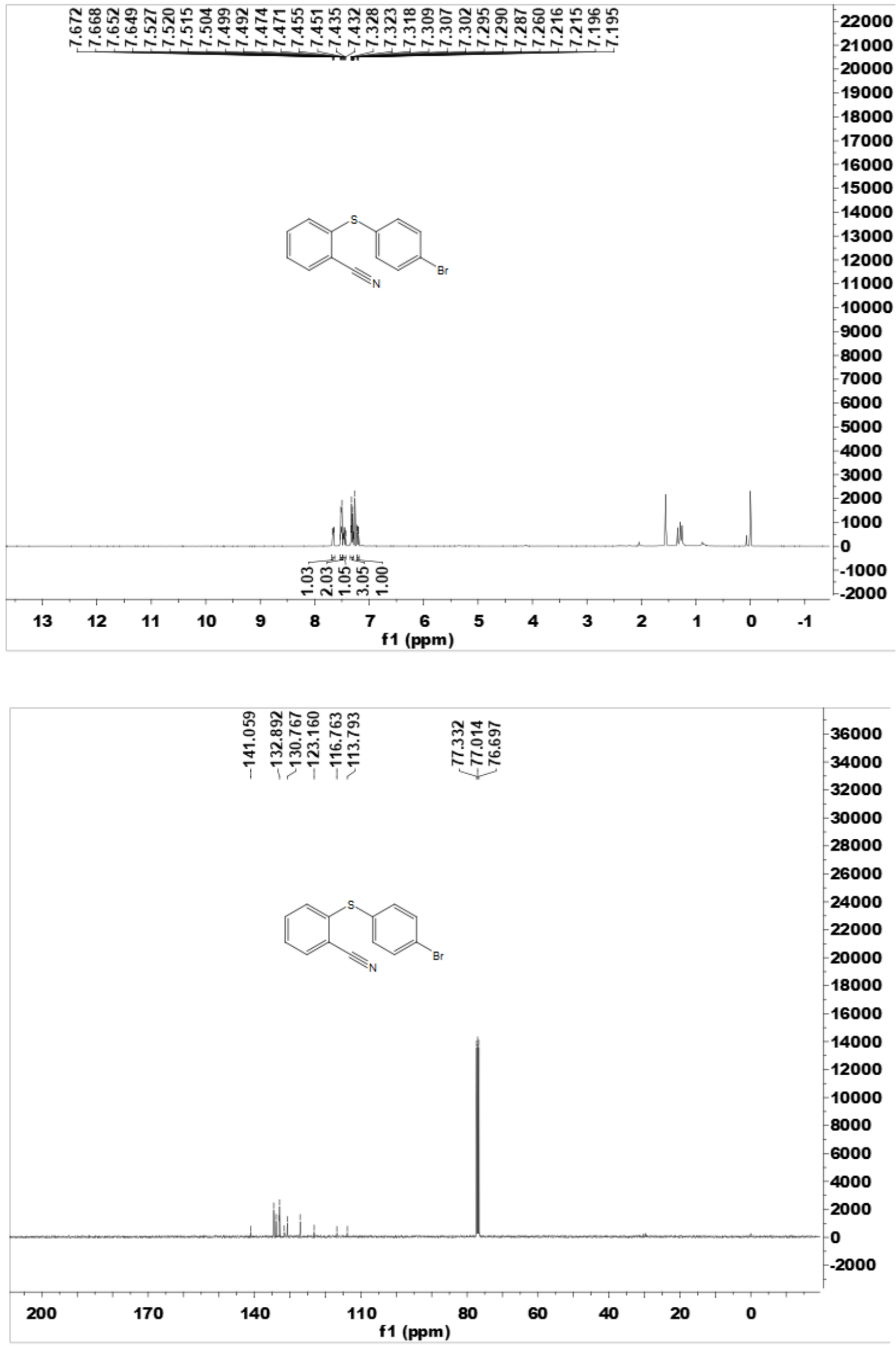
2-((2-Chlorophenyl)thio)benzonitrile (8r)
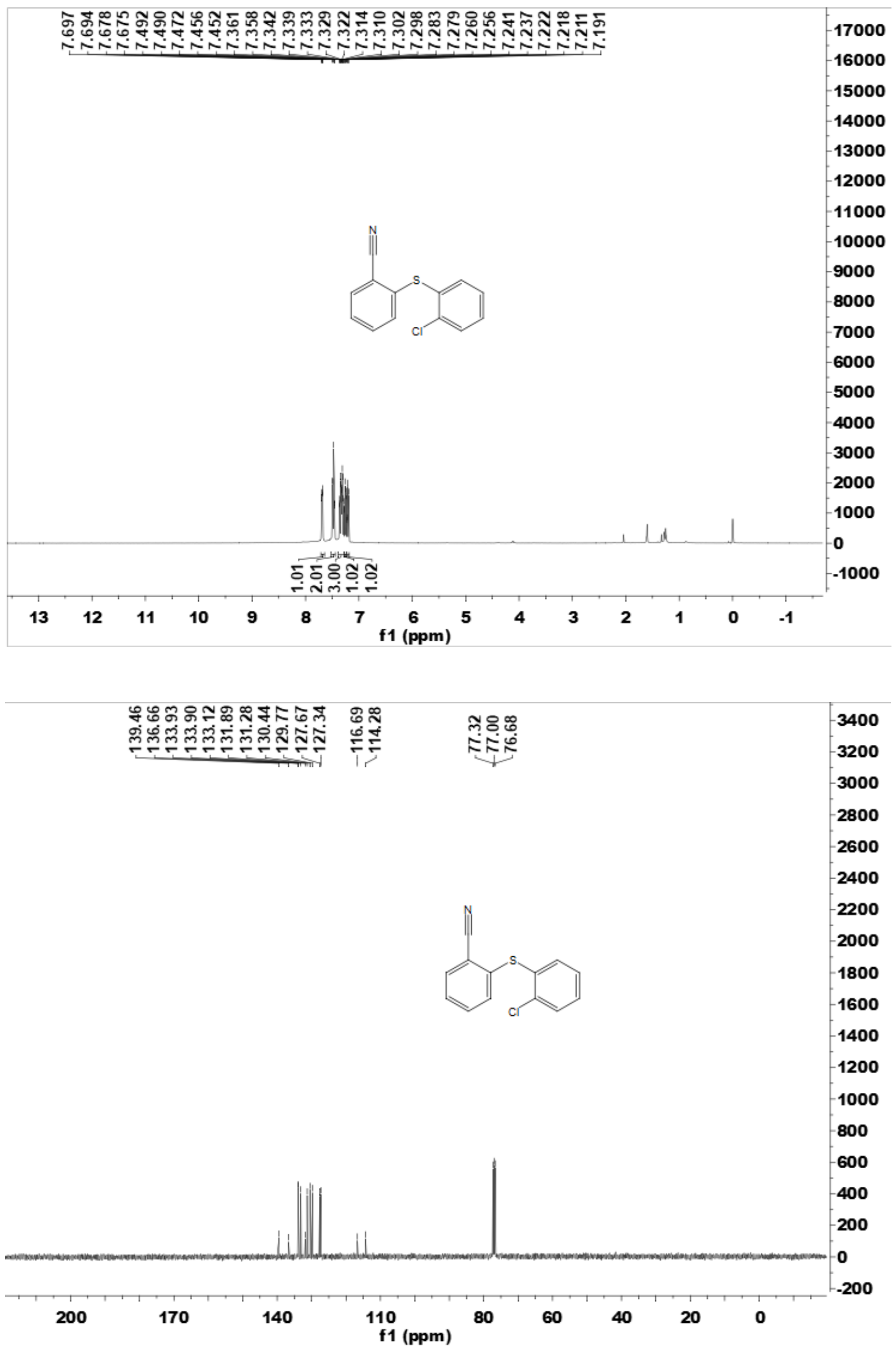
2-((2,6-Dimethylphenyl)thio)benzonitrile (8s)
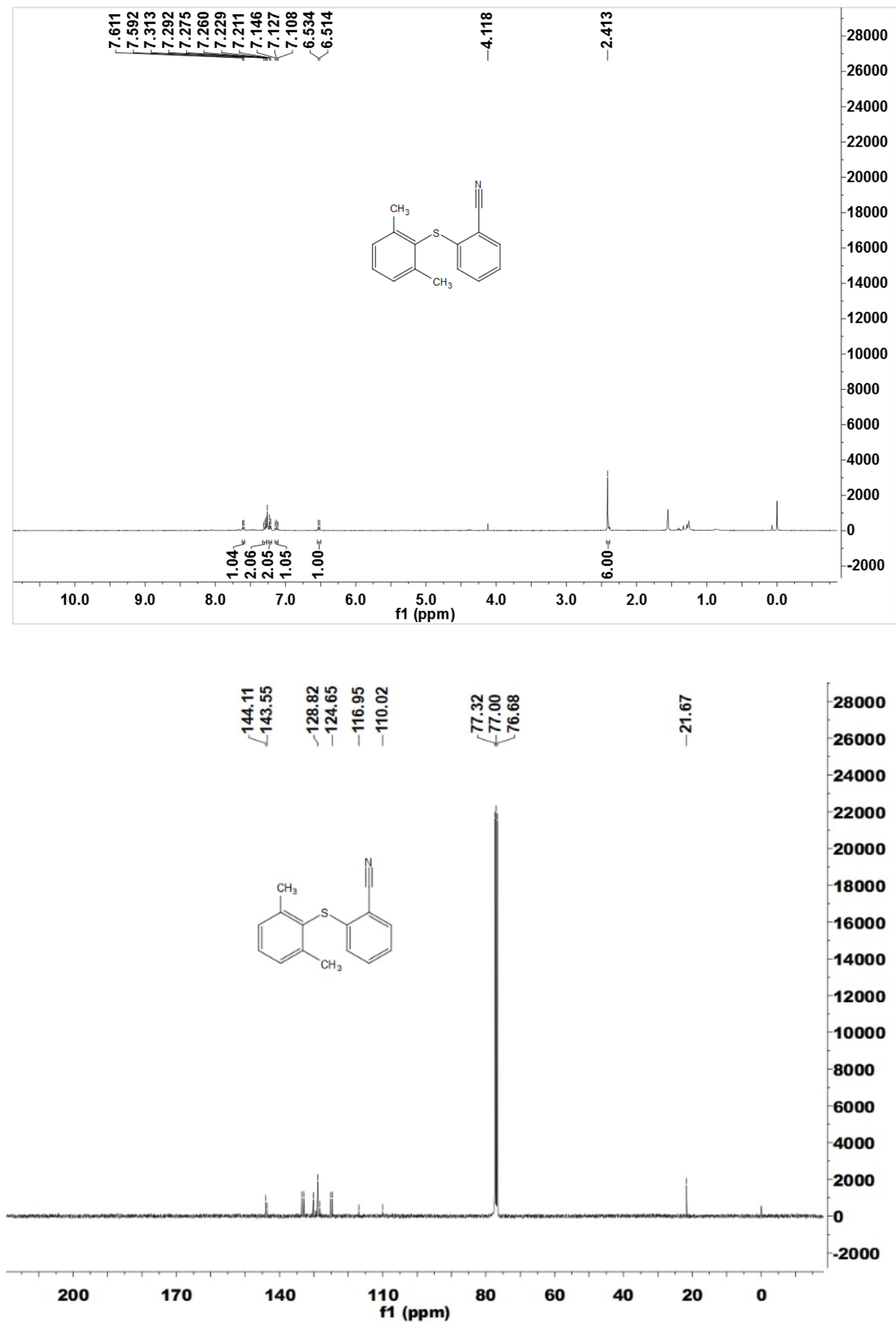
2-((2,6-Dimethylphenyl)thio)benzonitrile (8t)
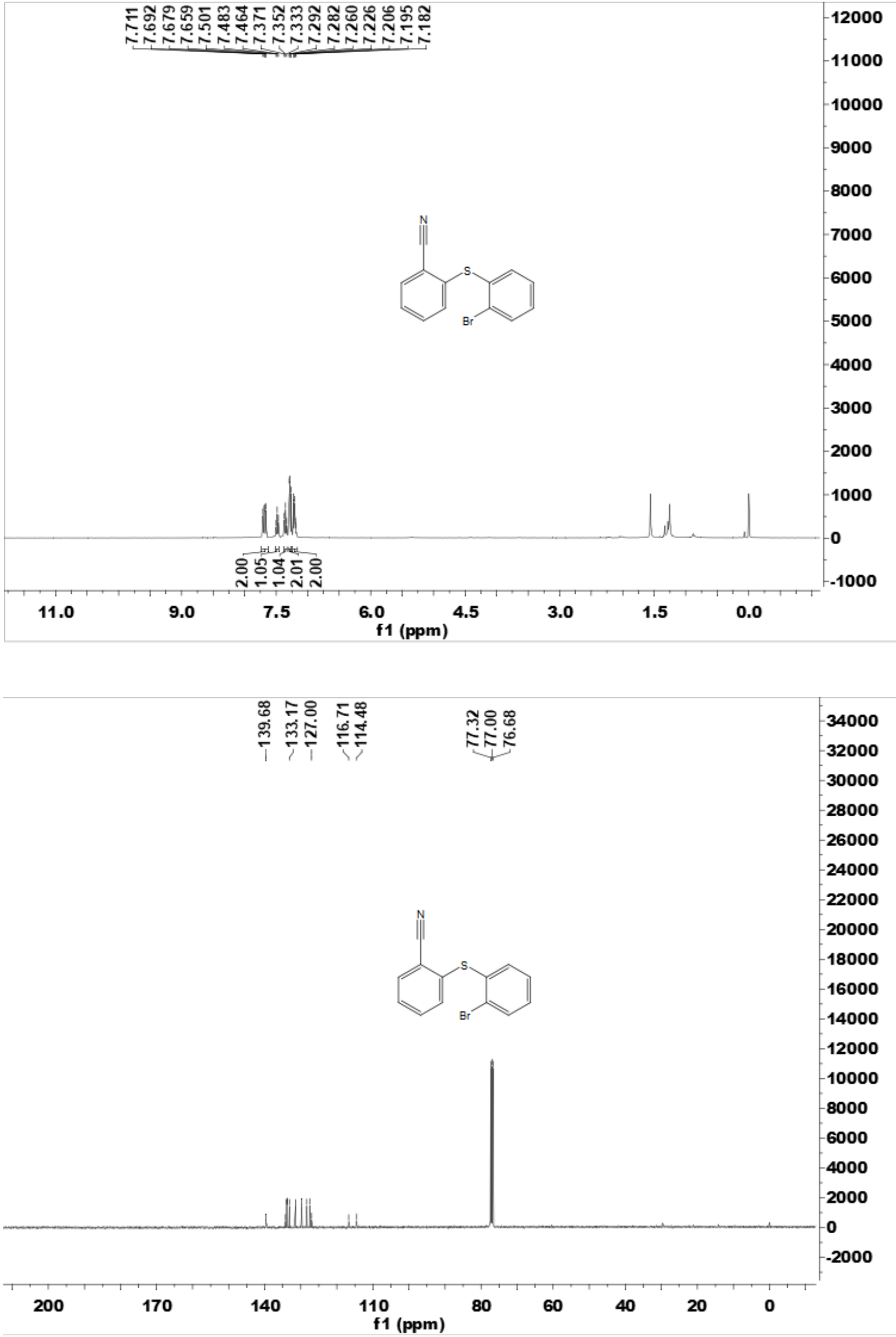

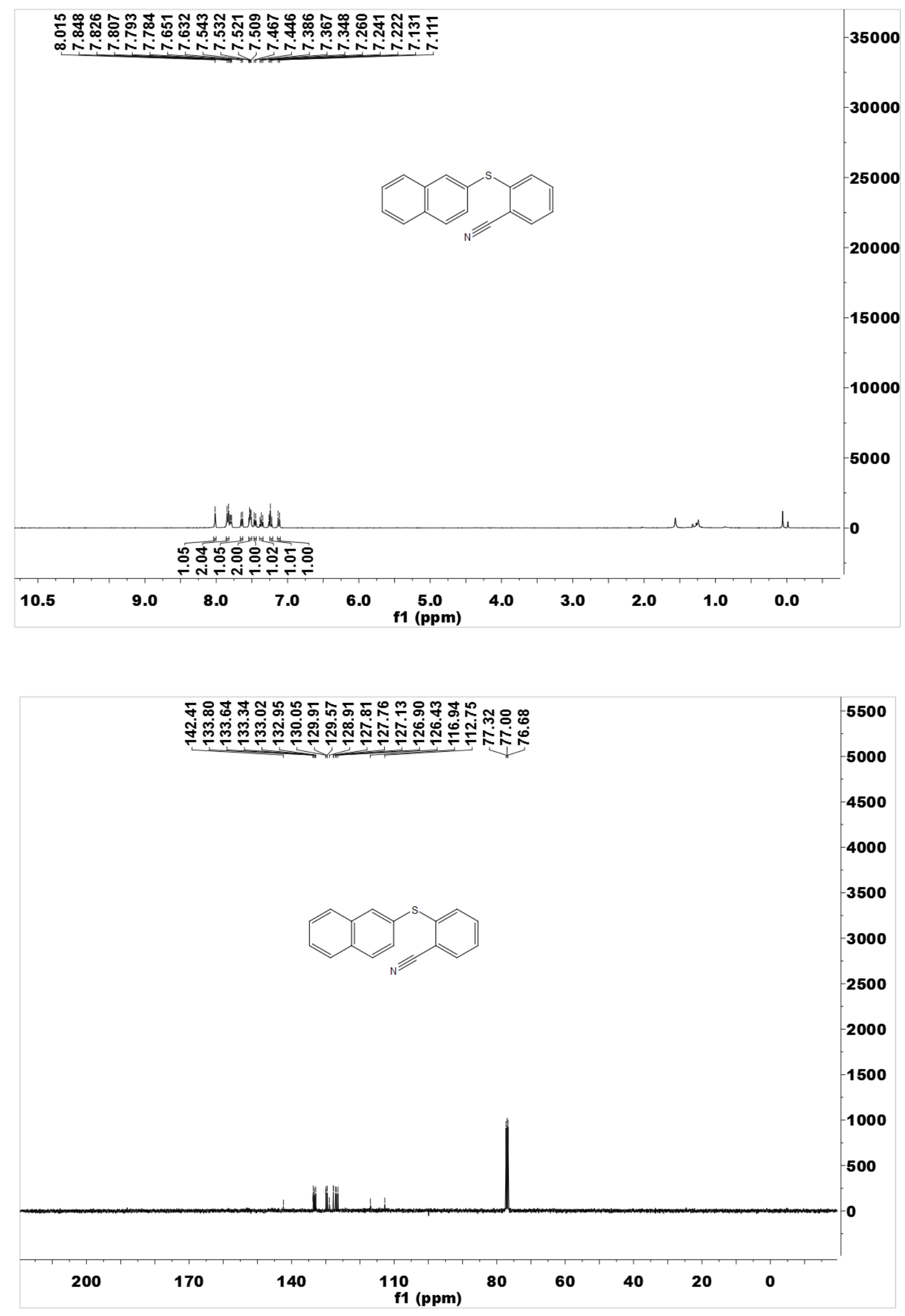
2-(Thiophen-2-ylthio)benzonitrile (8v)

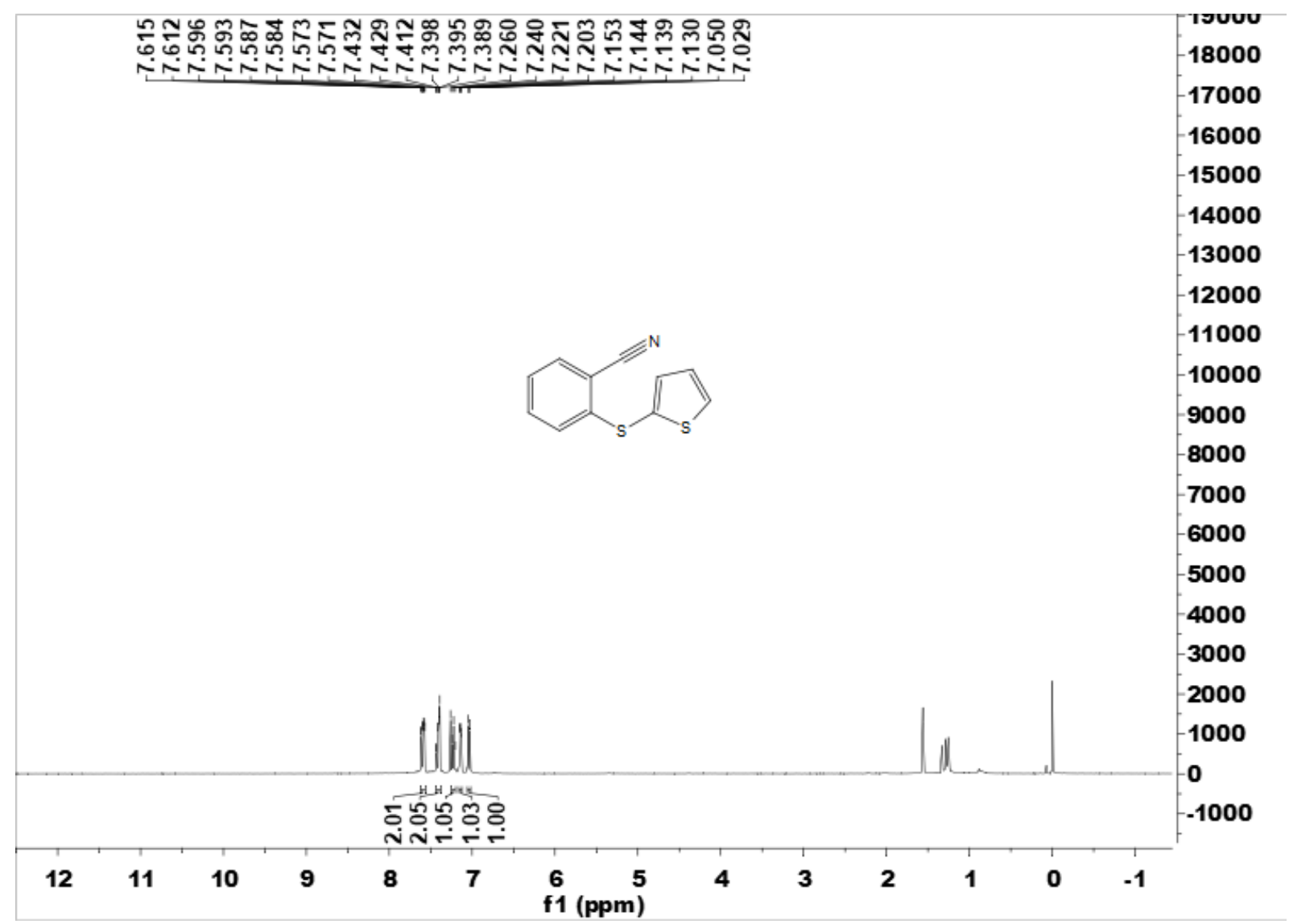

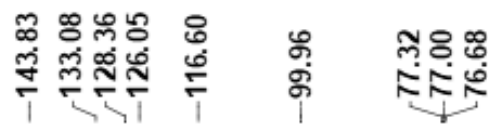

1800

1700

$-1600$

1500

1400

1300

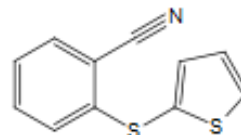

1200

1100

$-1000$

900

800

700

600

500

400

$-300$

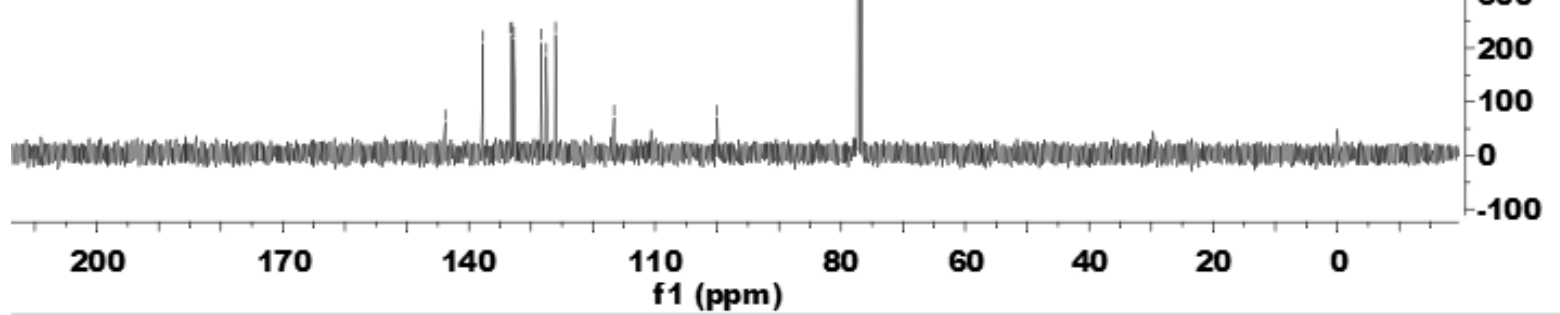


2-((Phenylthio)methyl)benzonitrile (8w)

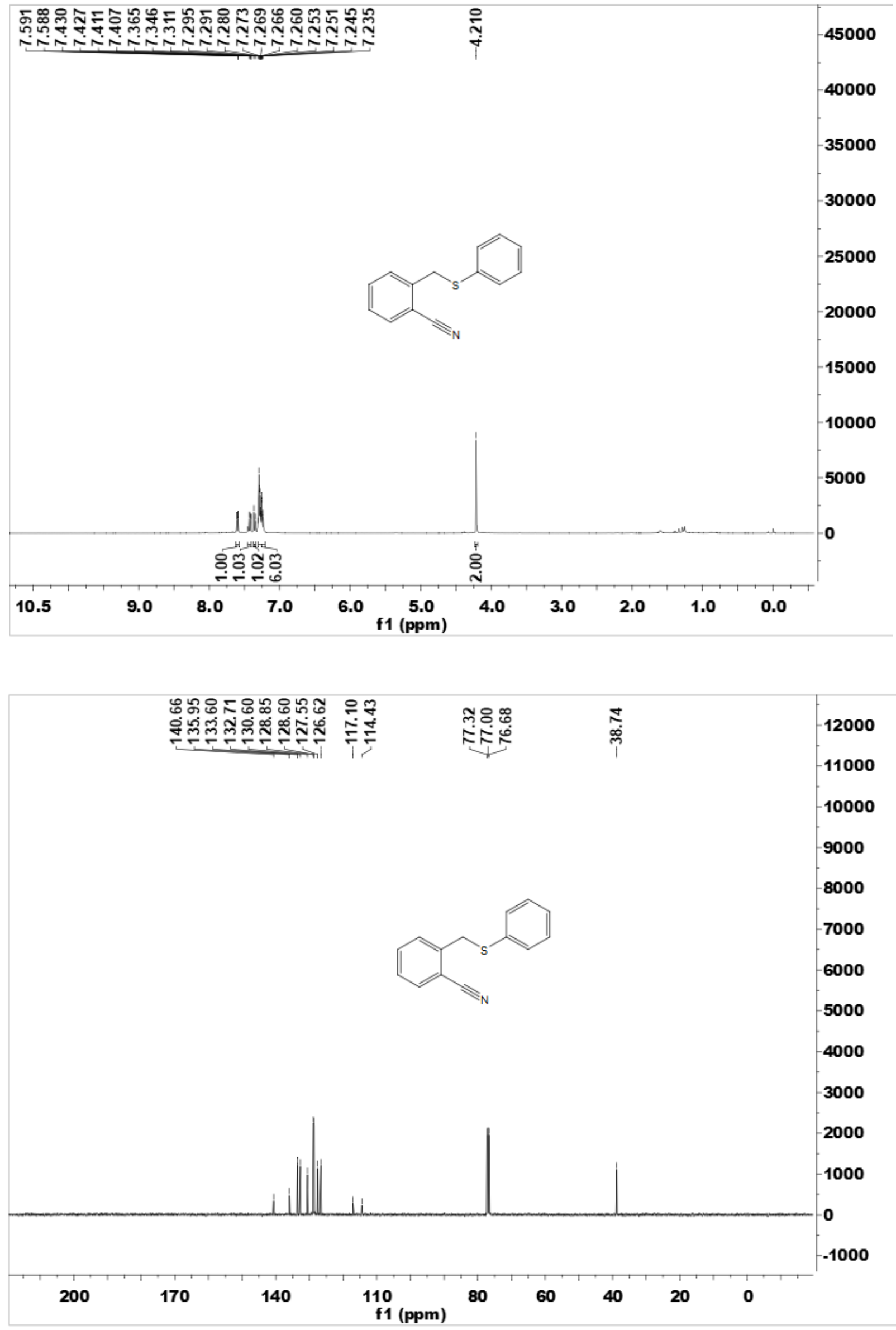


2-(Pentylthio)benzonitrile (8x)
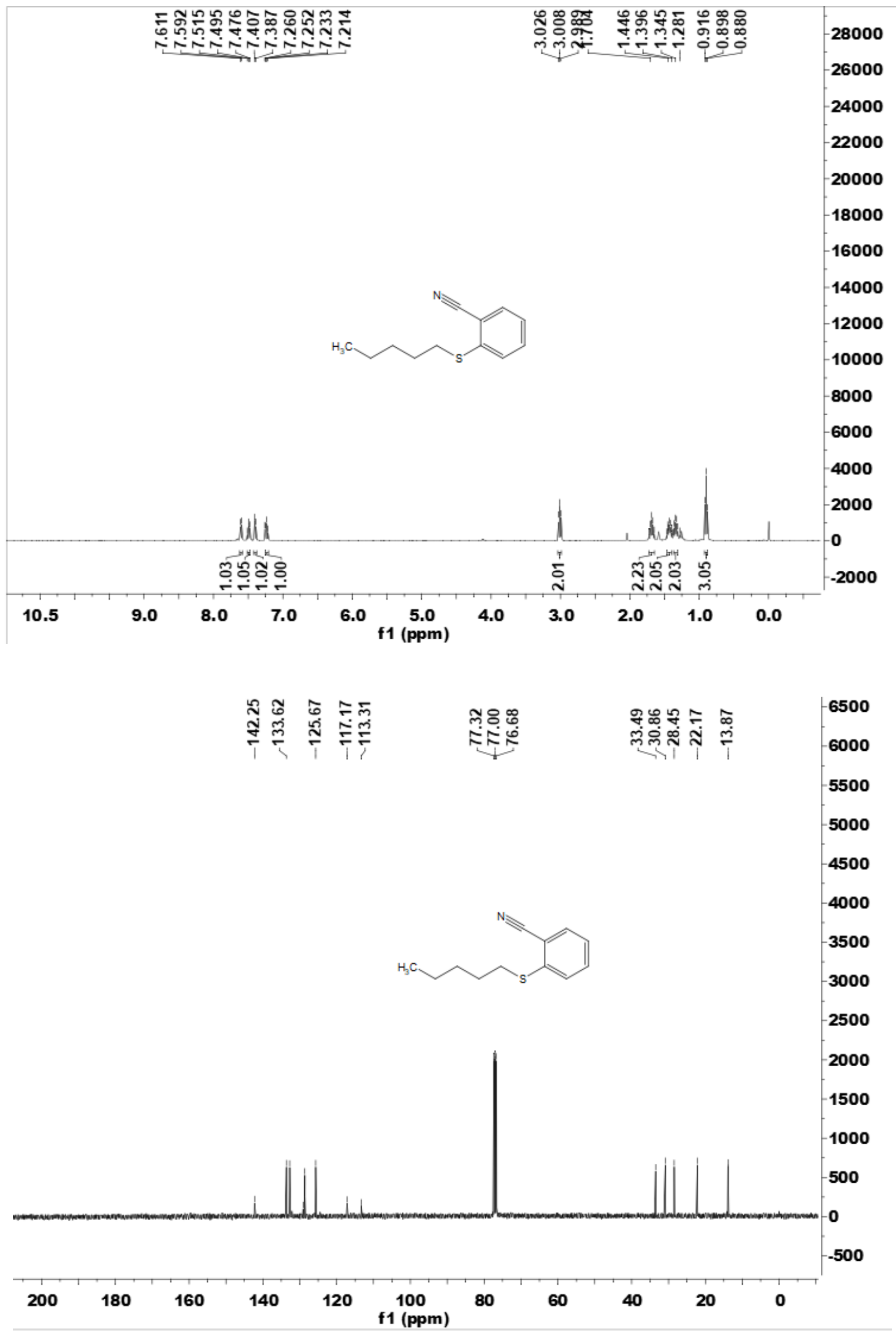
Methyl 4-cyano-3-(phenylthio)benzoate (8y)
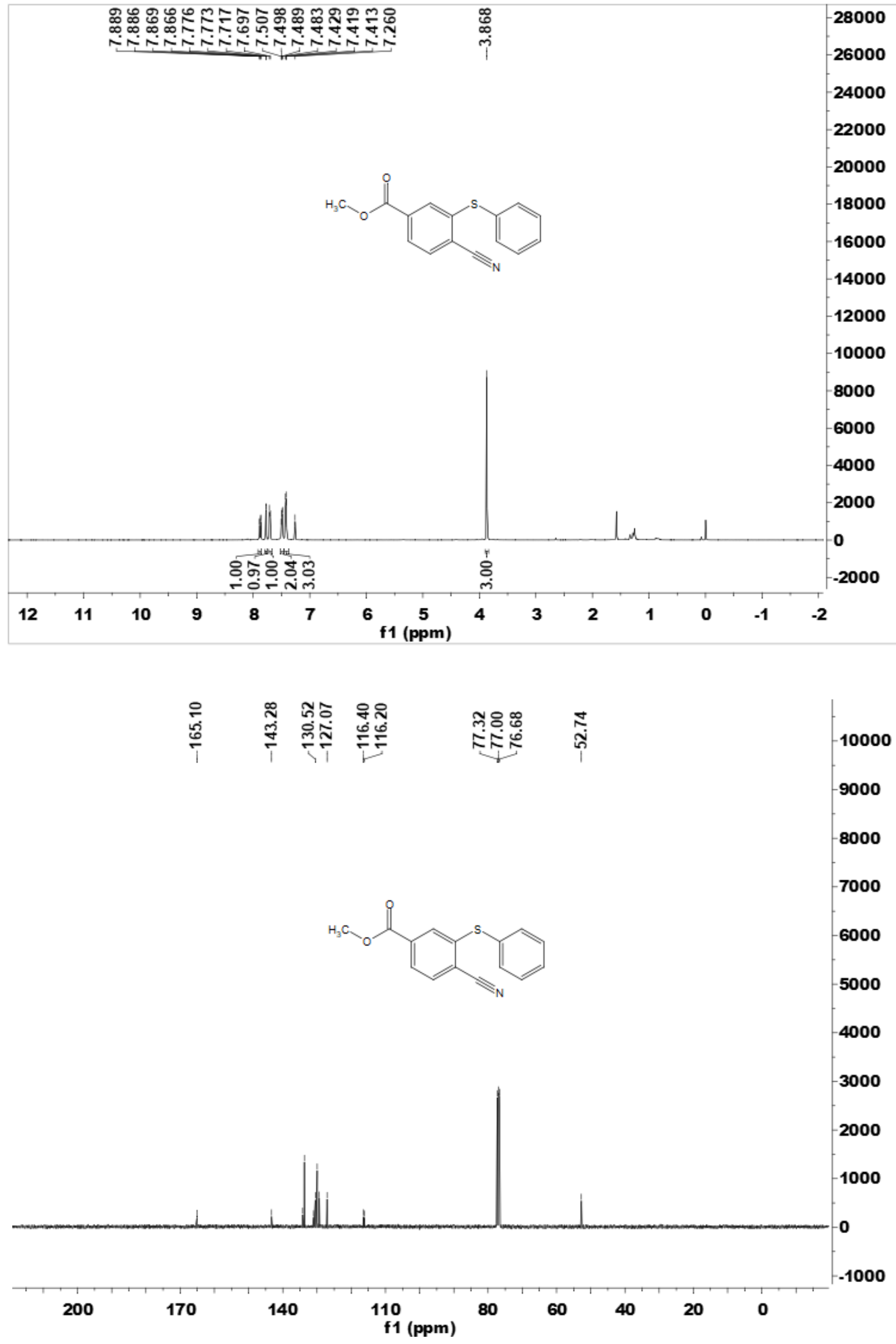
4-Cyano-3-(phenylthio)phenyl pivalate (8z)
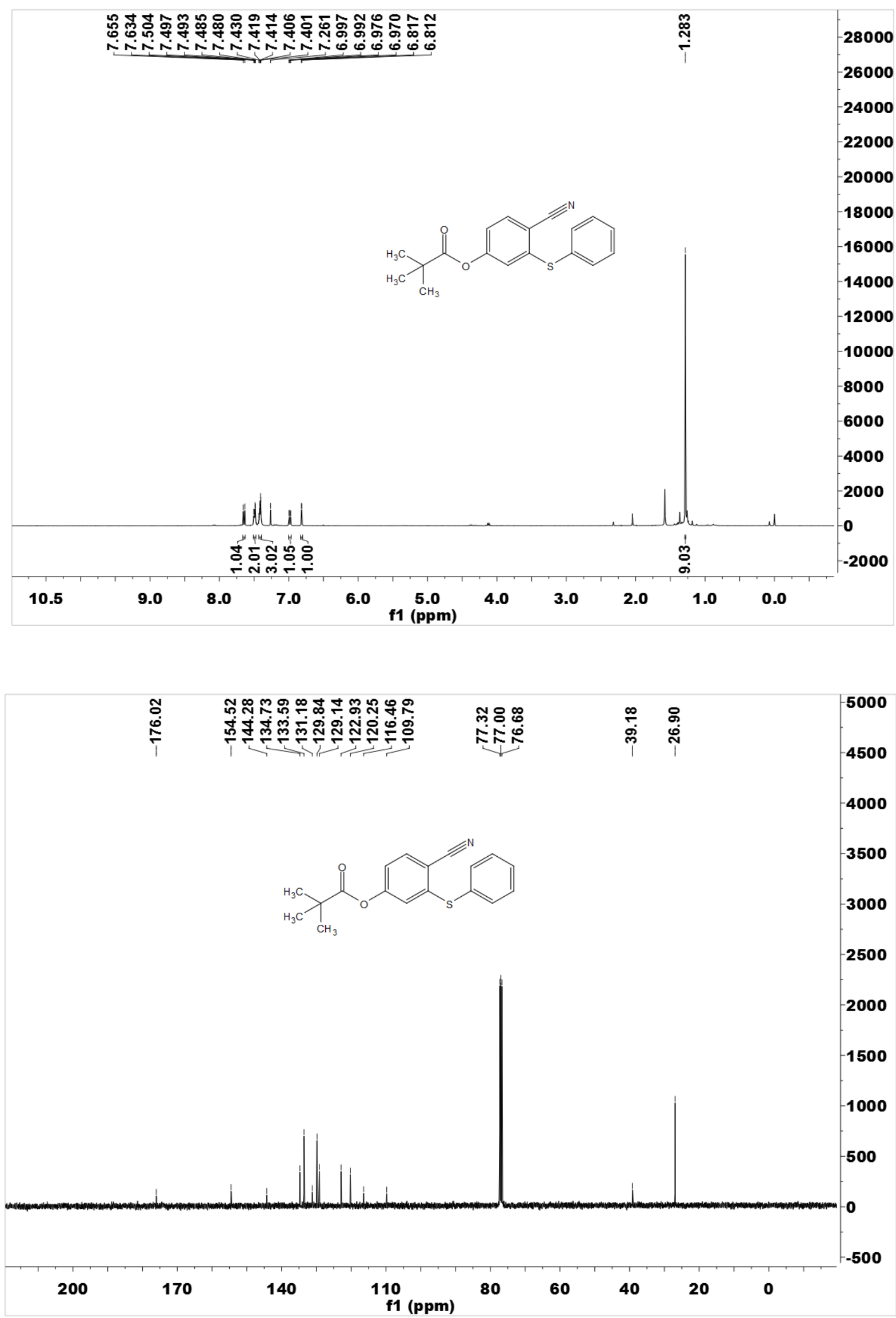
Ethyl 4-acetyl-2-(phenylthio)benzimidate $(9 \mathrm{j})$
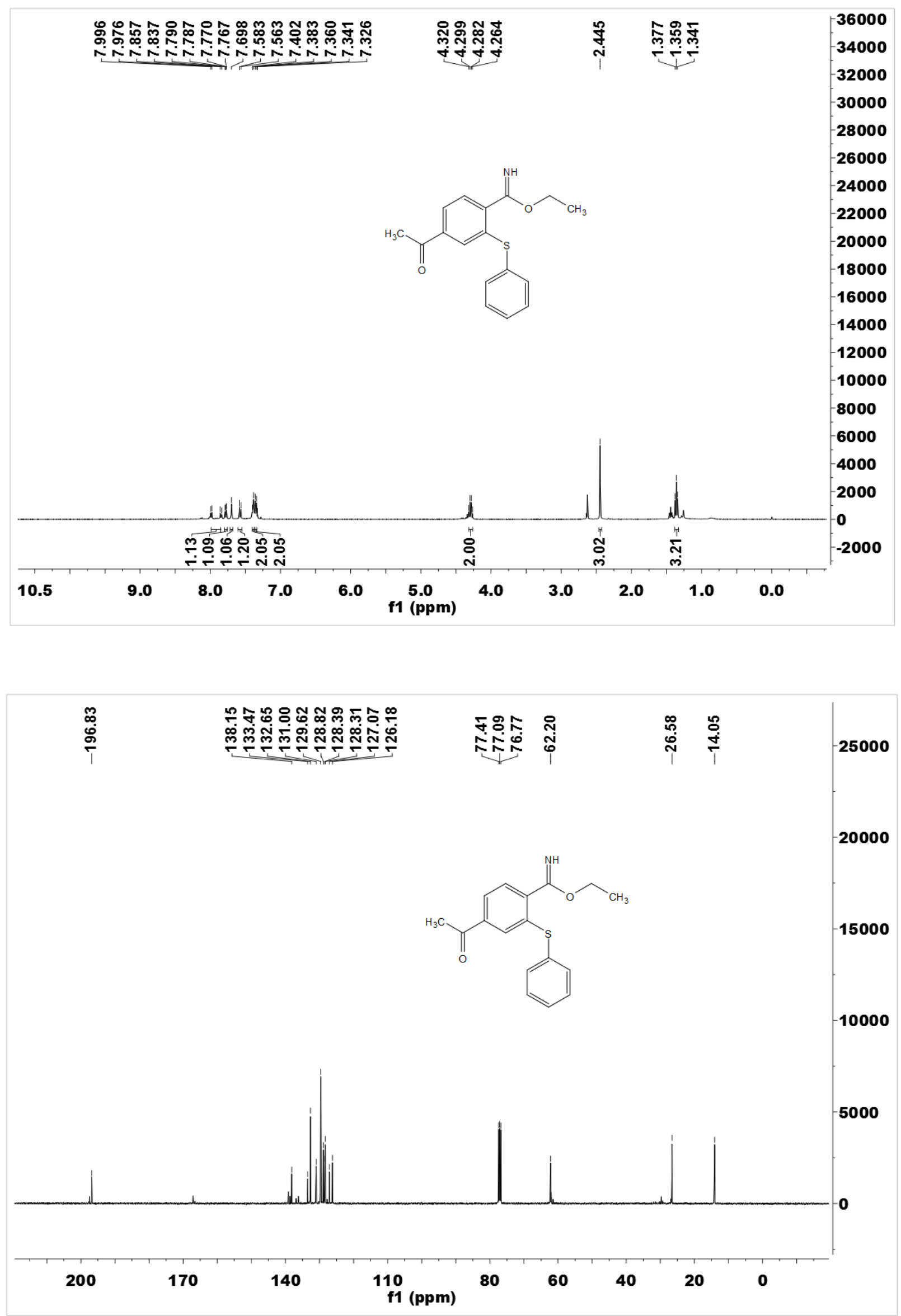
Ethyl 3-(phenylthio)-4-(1H-pyrazol-1-yl)benzimidate (9k)
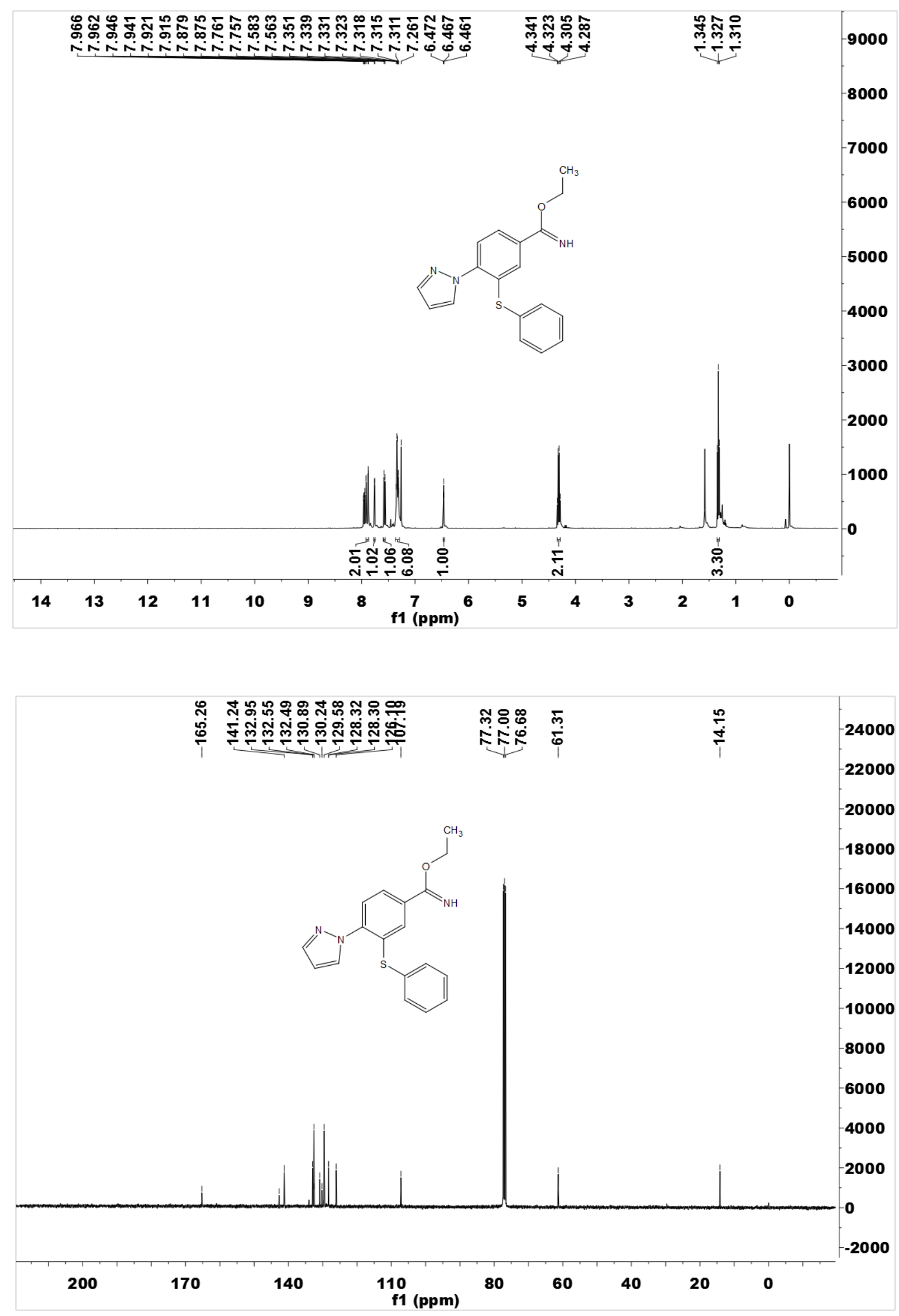
Ethyl 2-(phenylthio)benzimidate (9a)
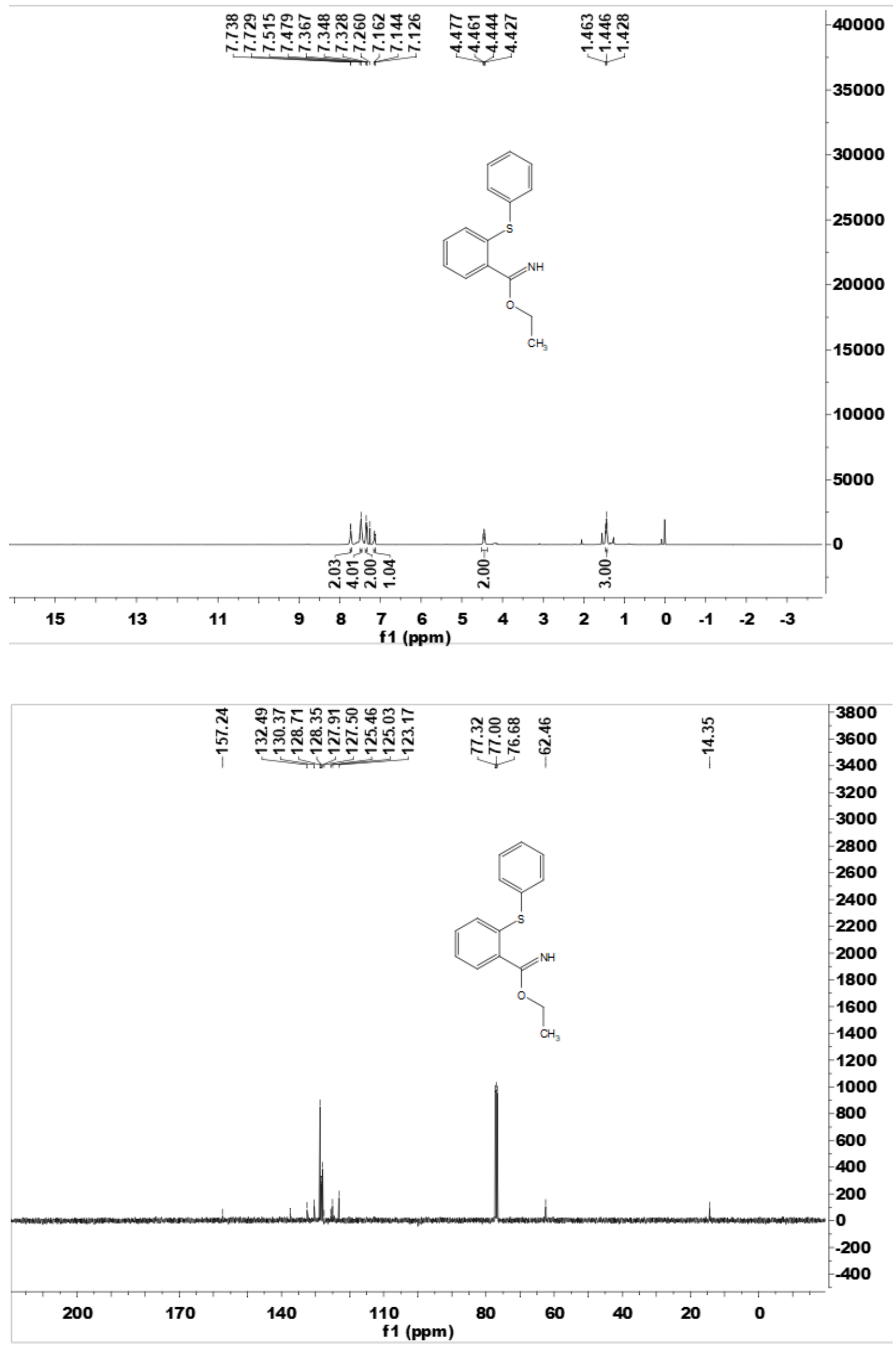
Ethyl 2-(p-tolylthio)benzimidate (9b)
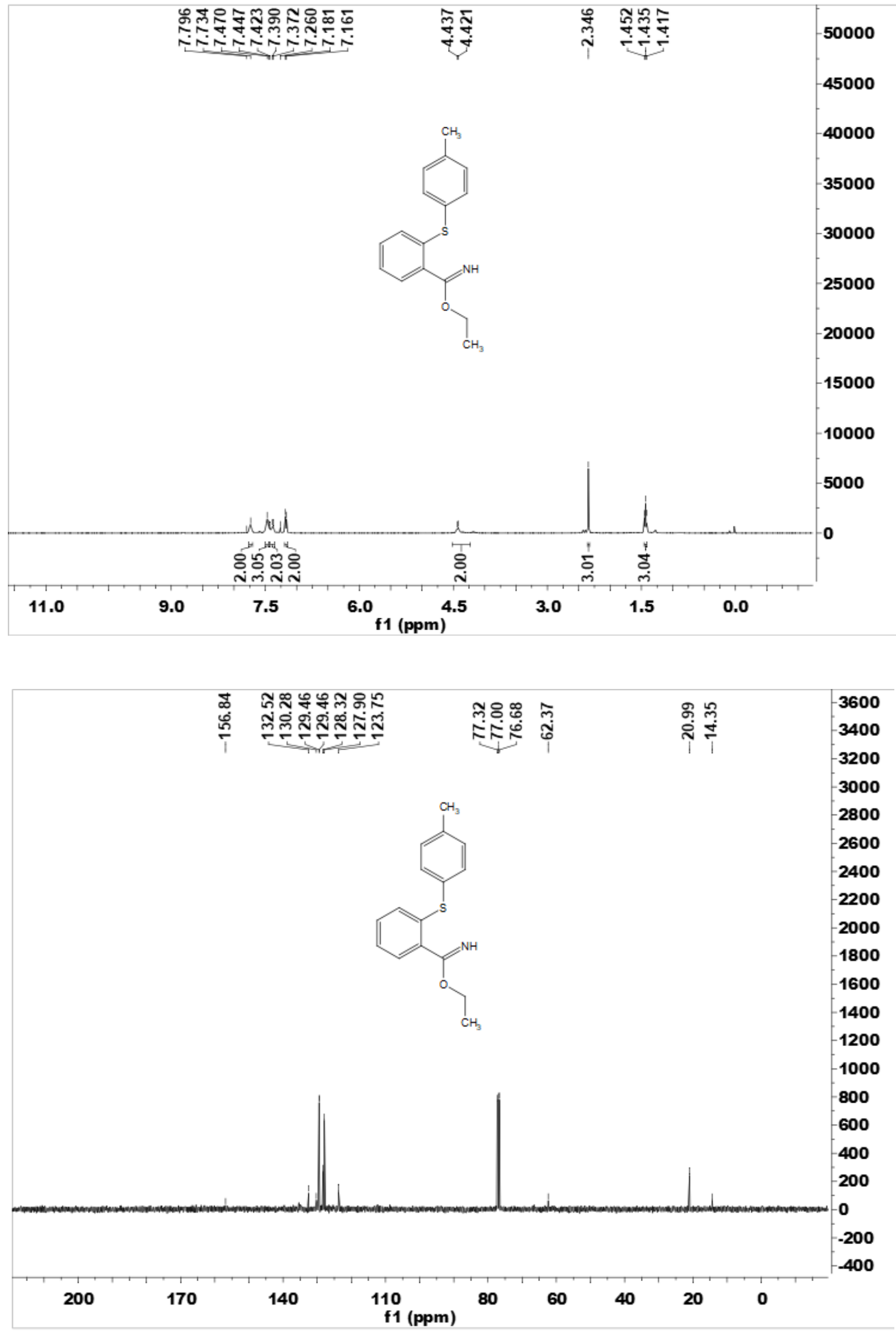
Ethyl 2-((4-bromophenyl)thio)benzimidate (9c),
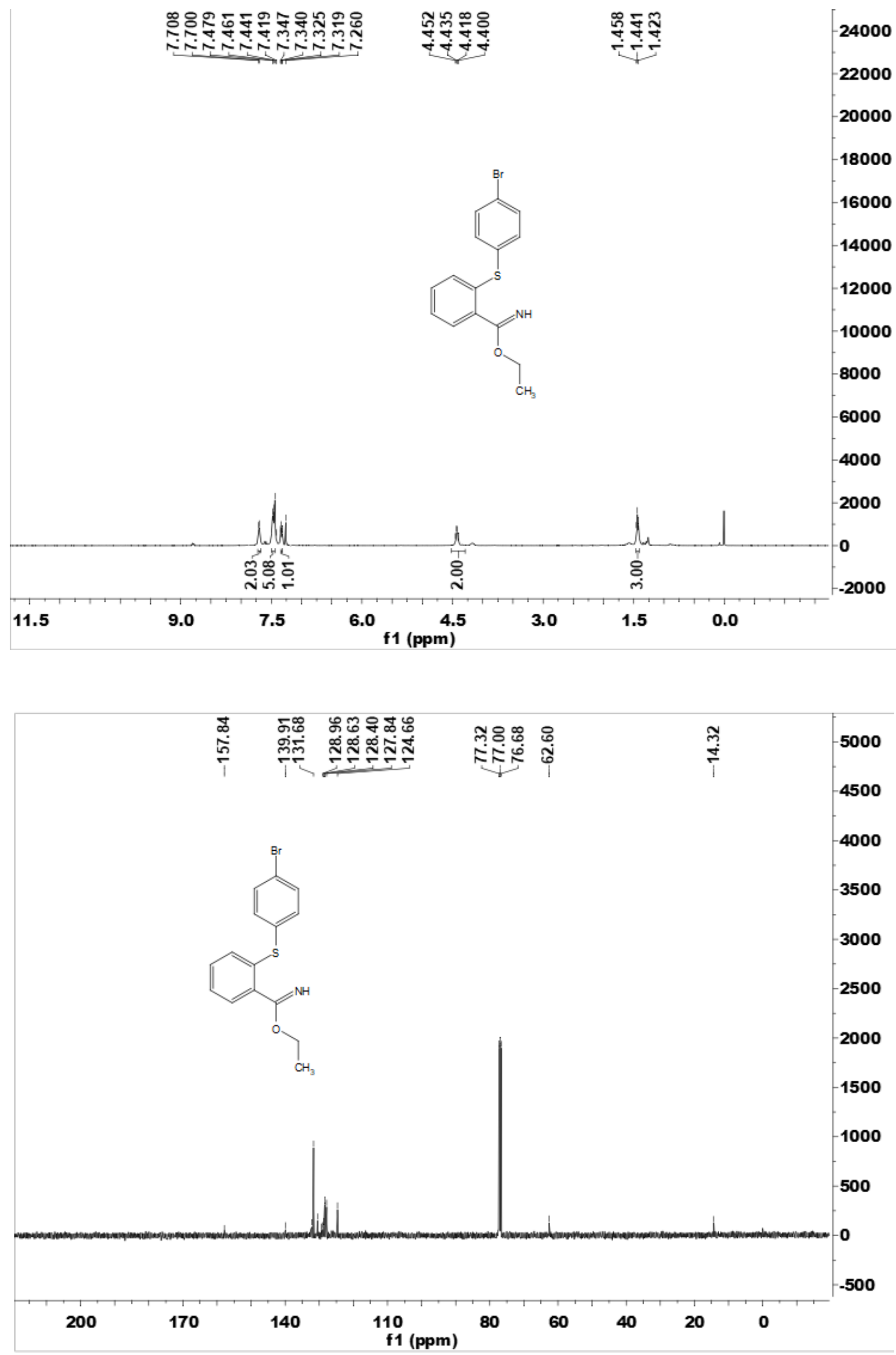
Ethyl 2-((2,4-dichlorophenyl)thio)benzimidate (9d)

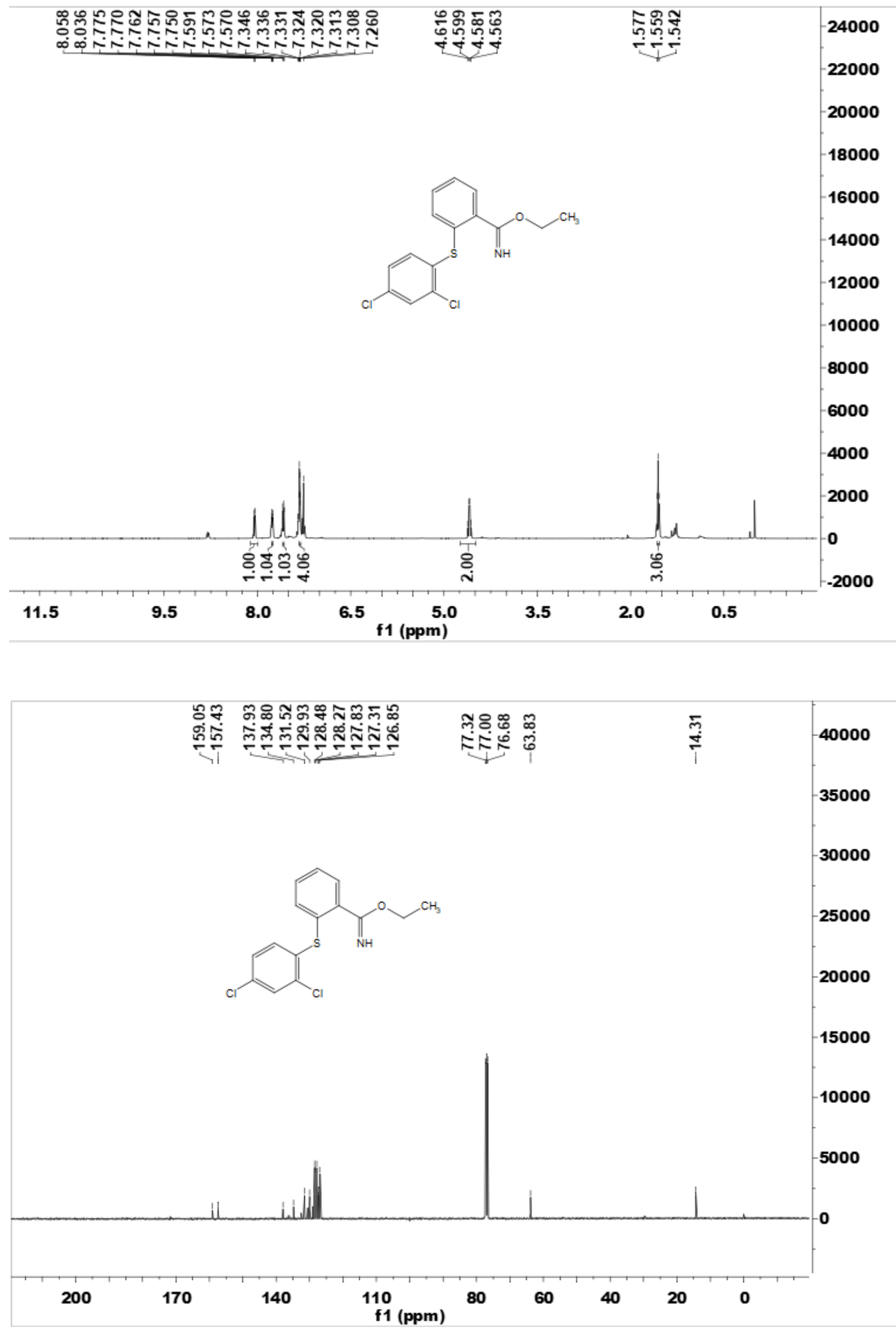


Methyl 4-((2-(ethoxy(imino)methyl)phenyl)thio)benzoate (9e)

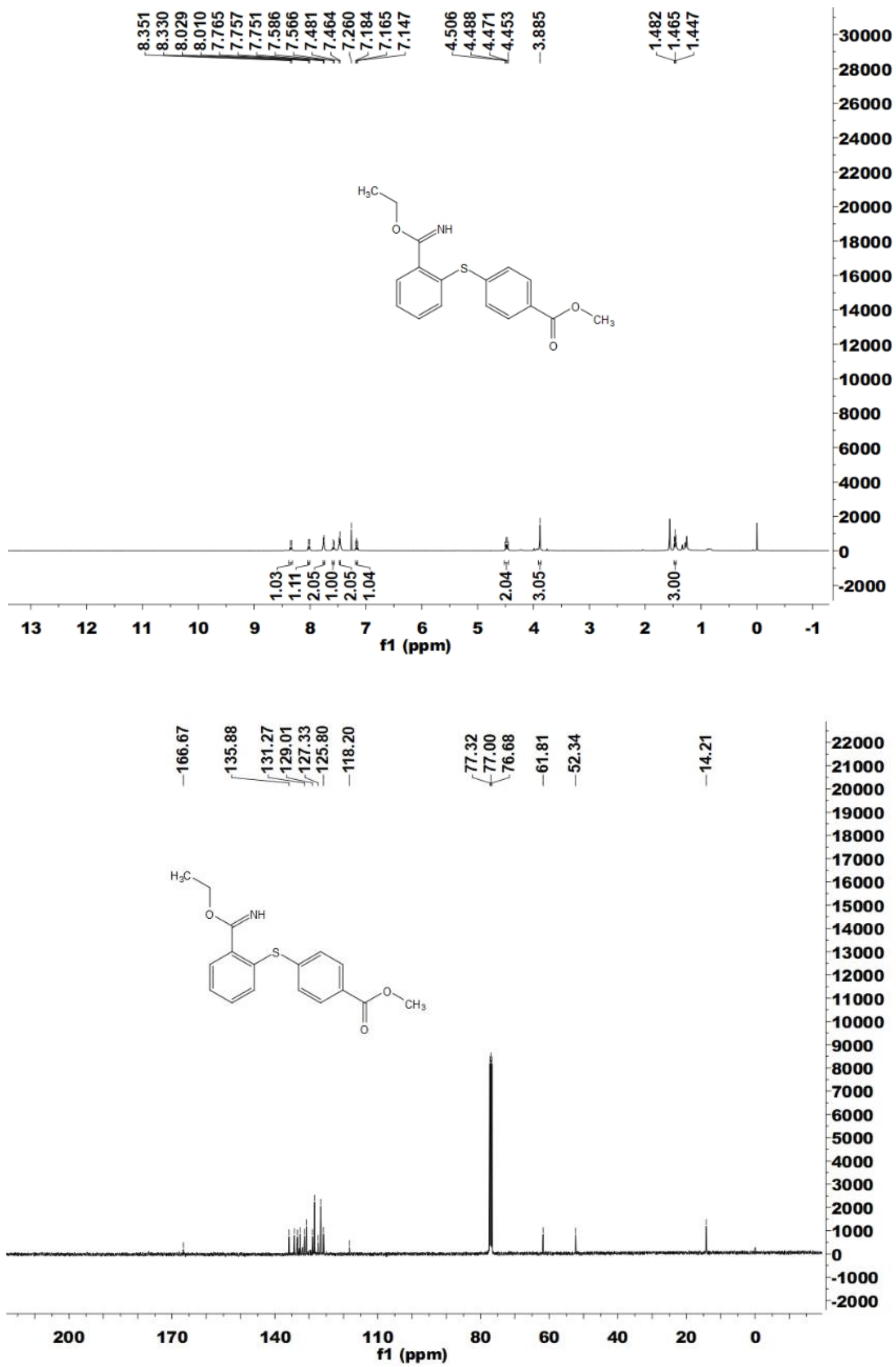


Ethyl 2-((2-fluorophenyl)thio)benzimidate (9f)
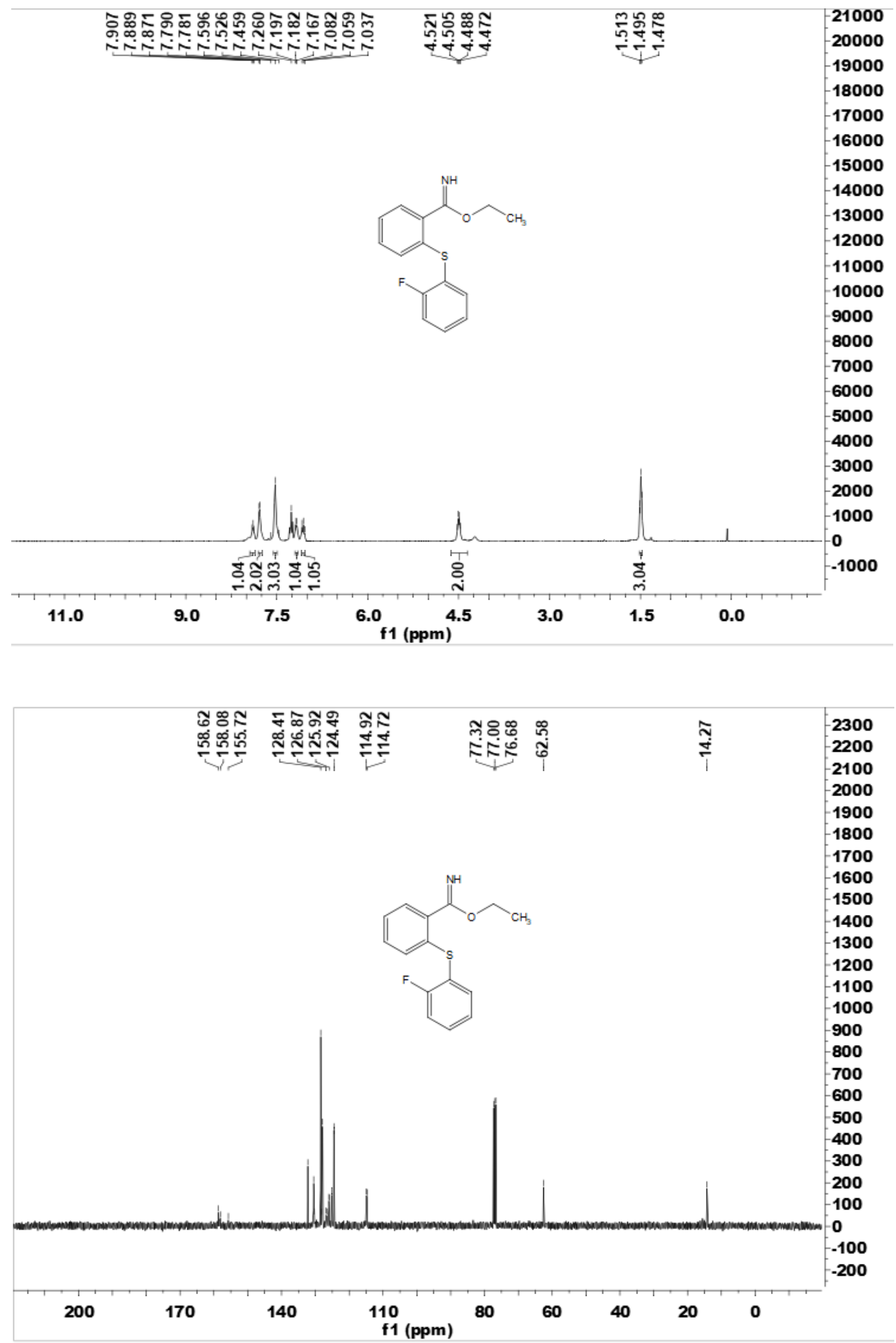
Ethyl 3-(phenylthio)thiophene-2-carbimidate (9g)
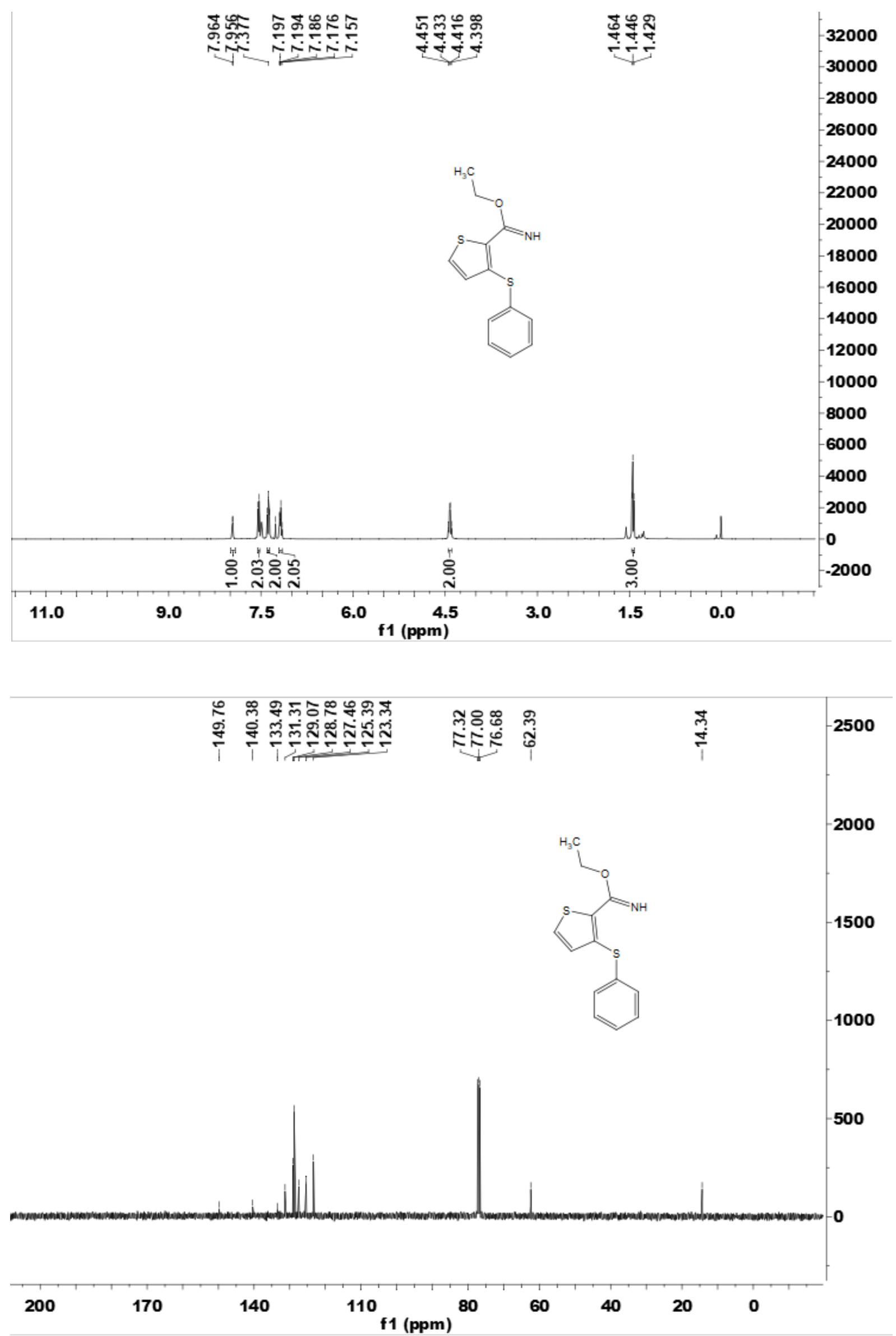
Ethyl 1,3-bis(phenylthio)-2-naphthimidate (9h)
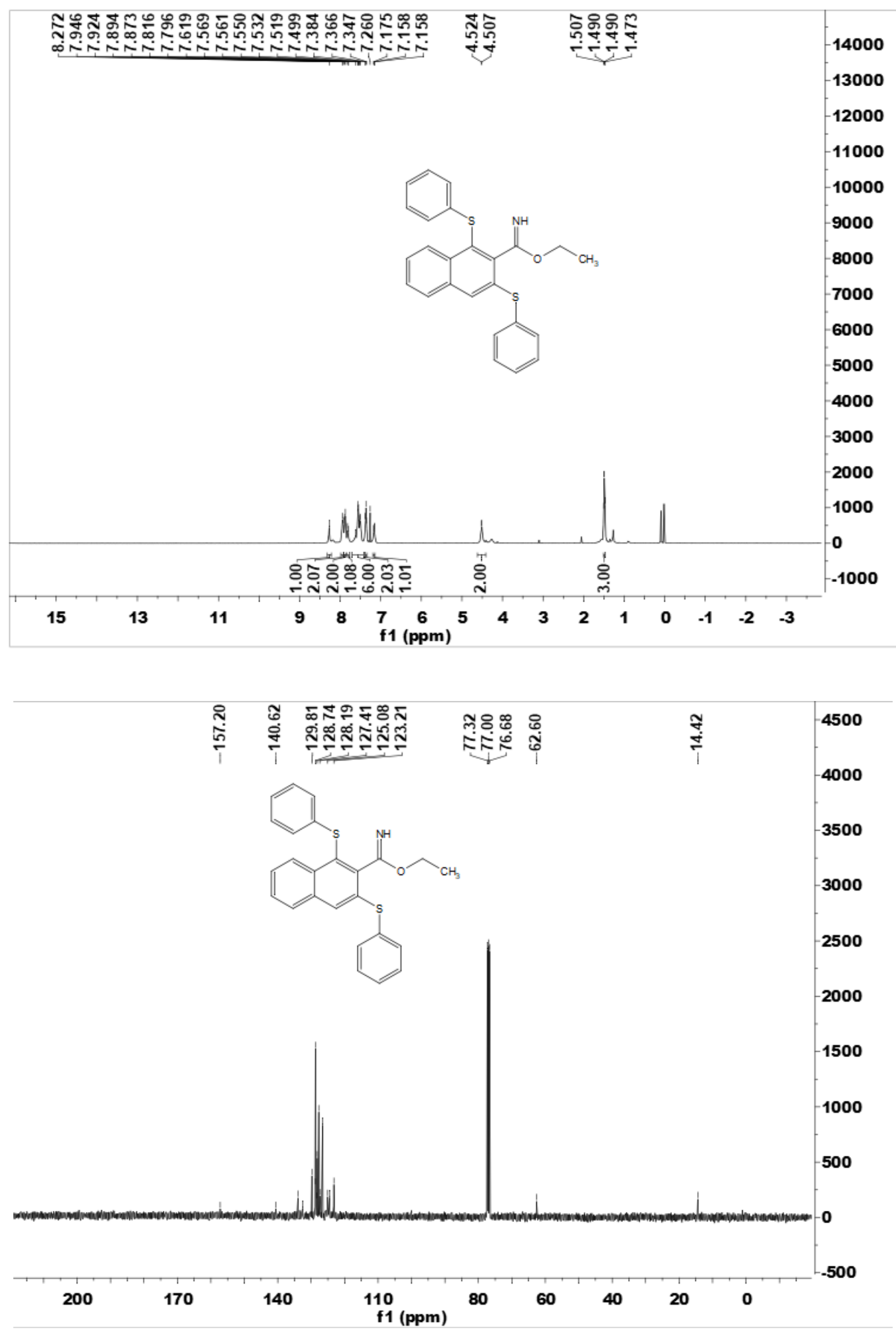
Ethyl 4-(2-(5-ethylpyridin-2-yl)ethoxy)-2-(p-tolylthio)benzimidate (9i)
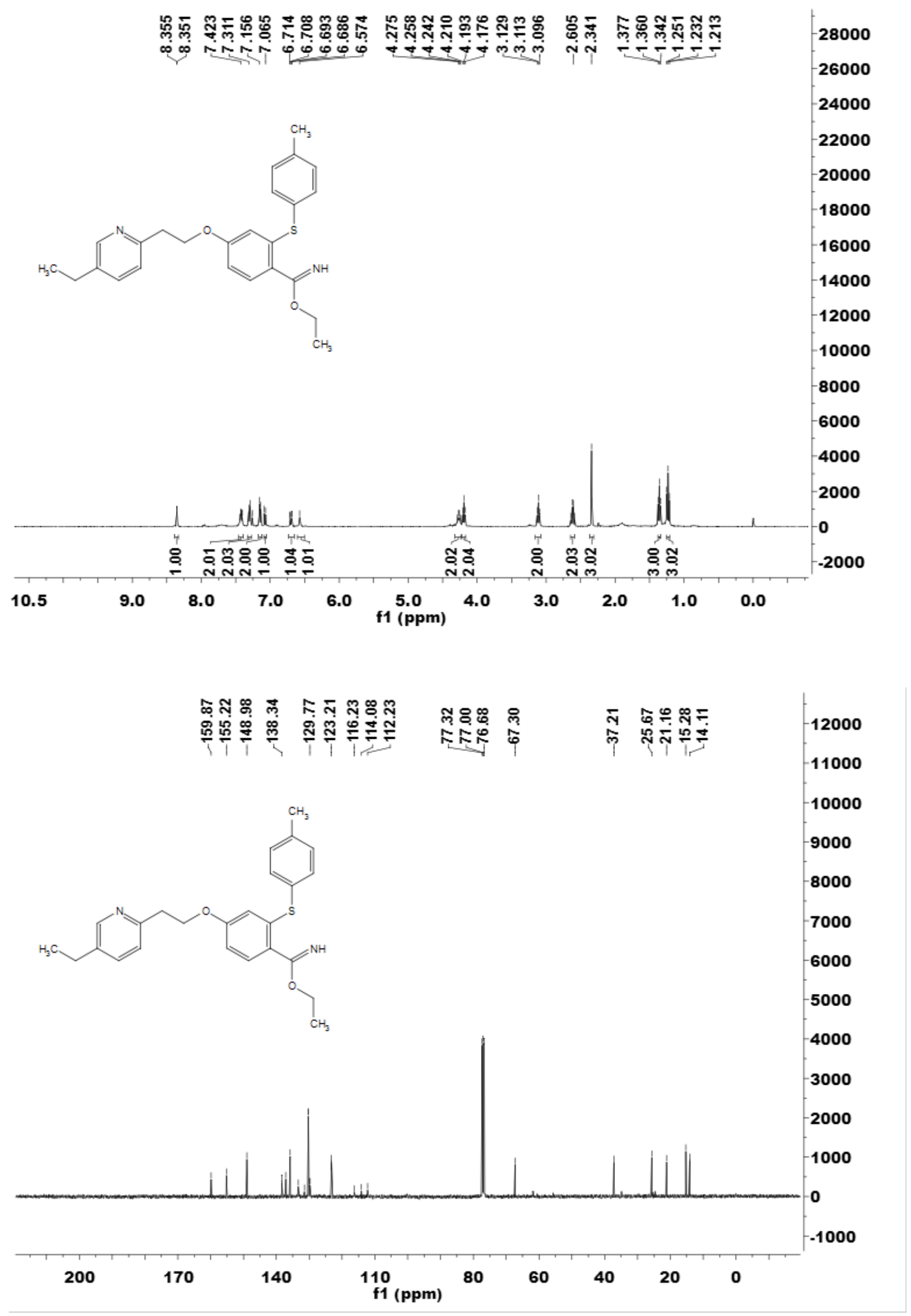
4'-(Hexyloxy)-3-(phenylthio)-[1,1'-biphenyl]-4-carbonitrile (10a)
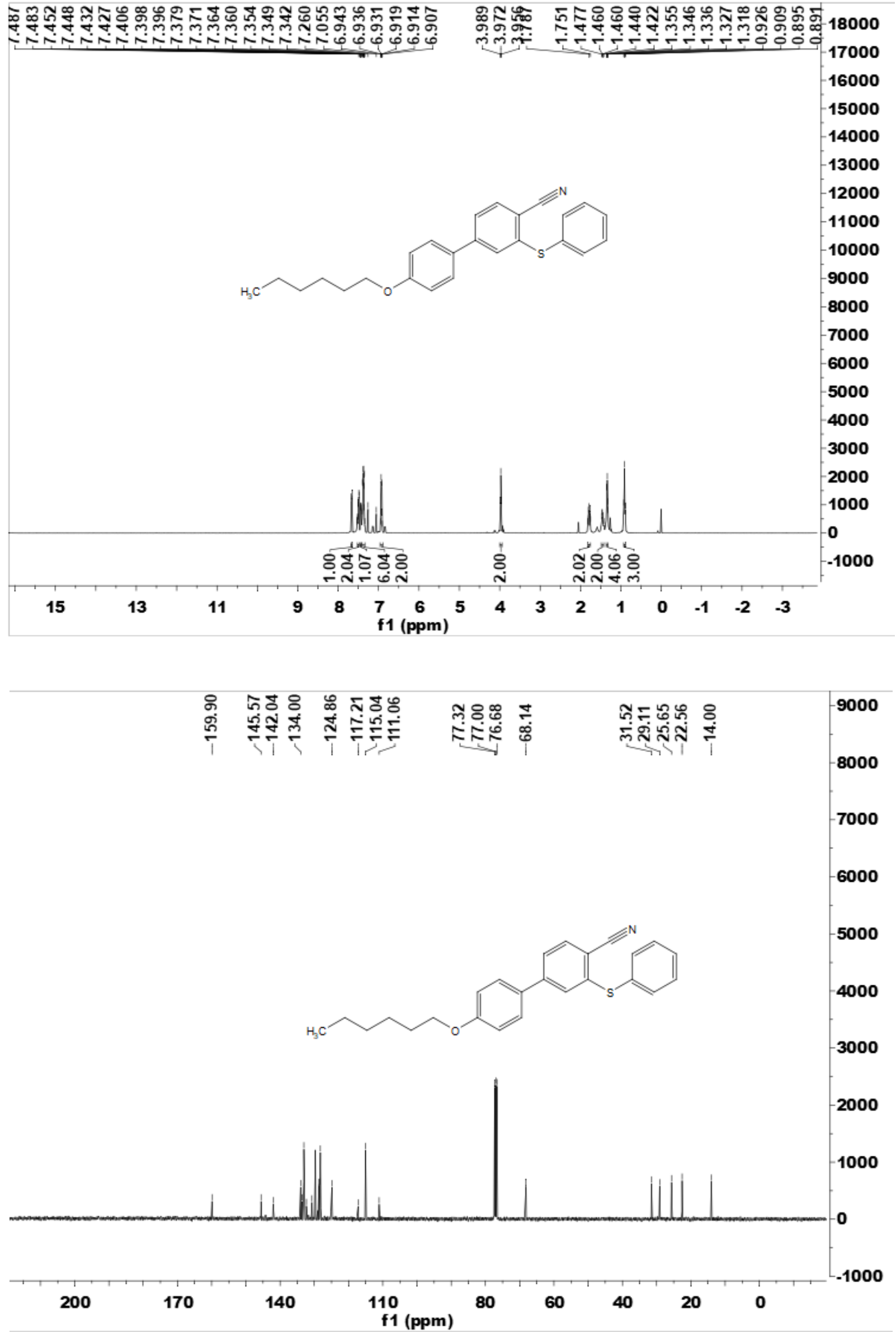

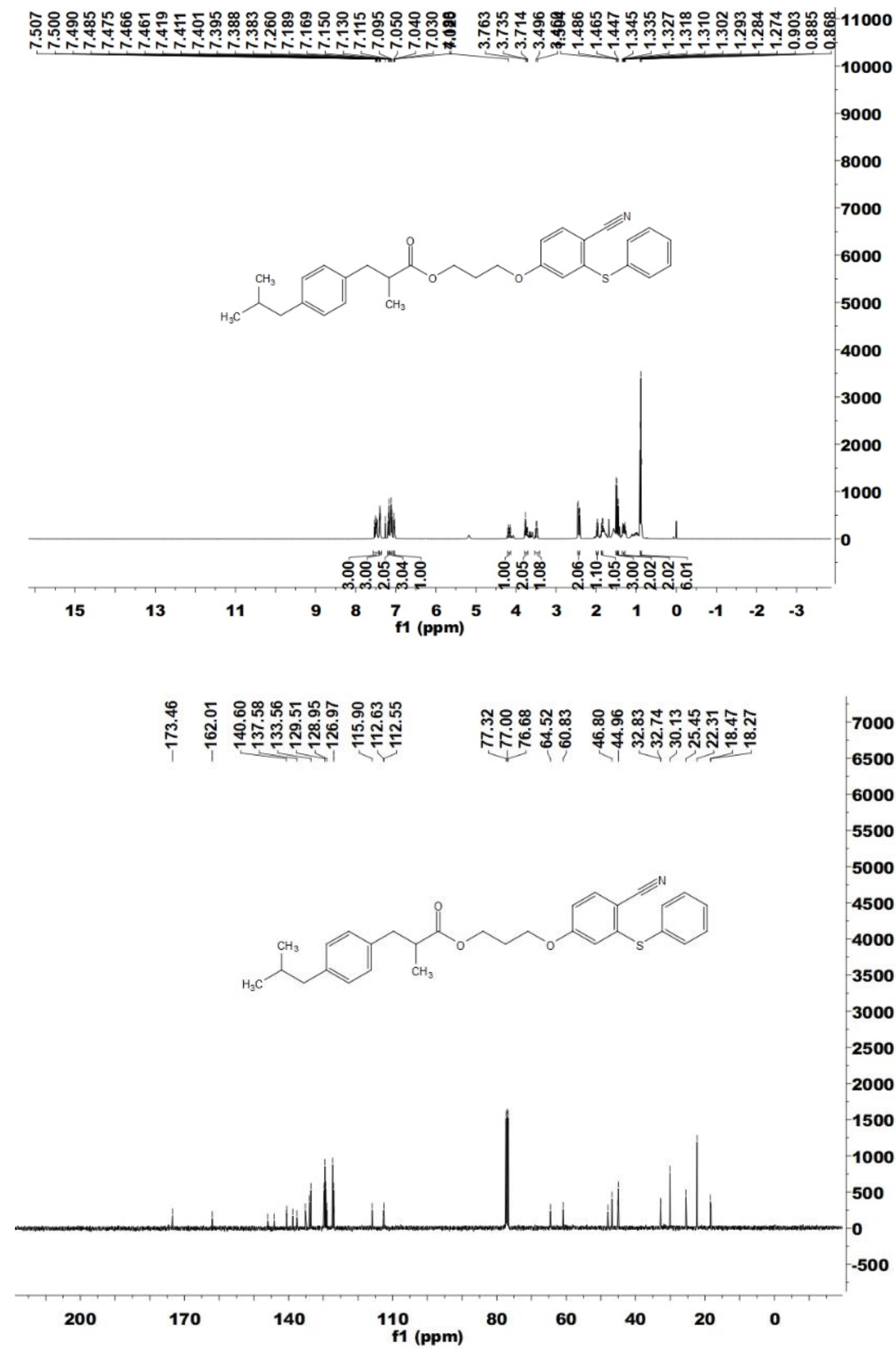


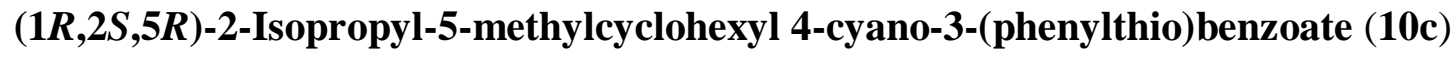
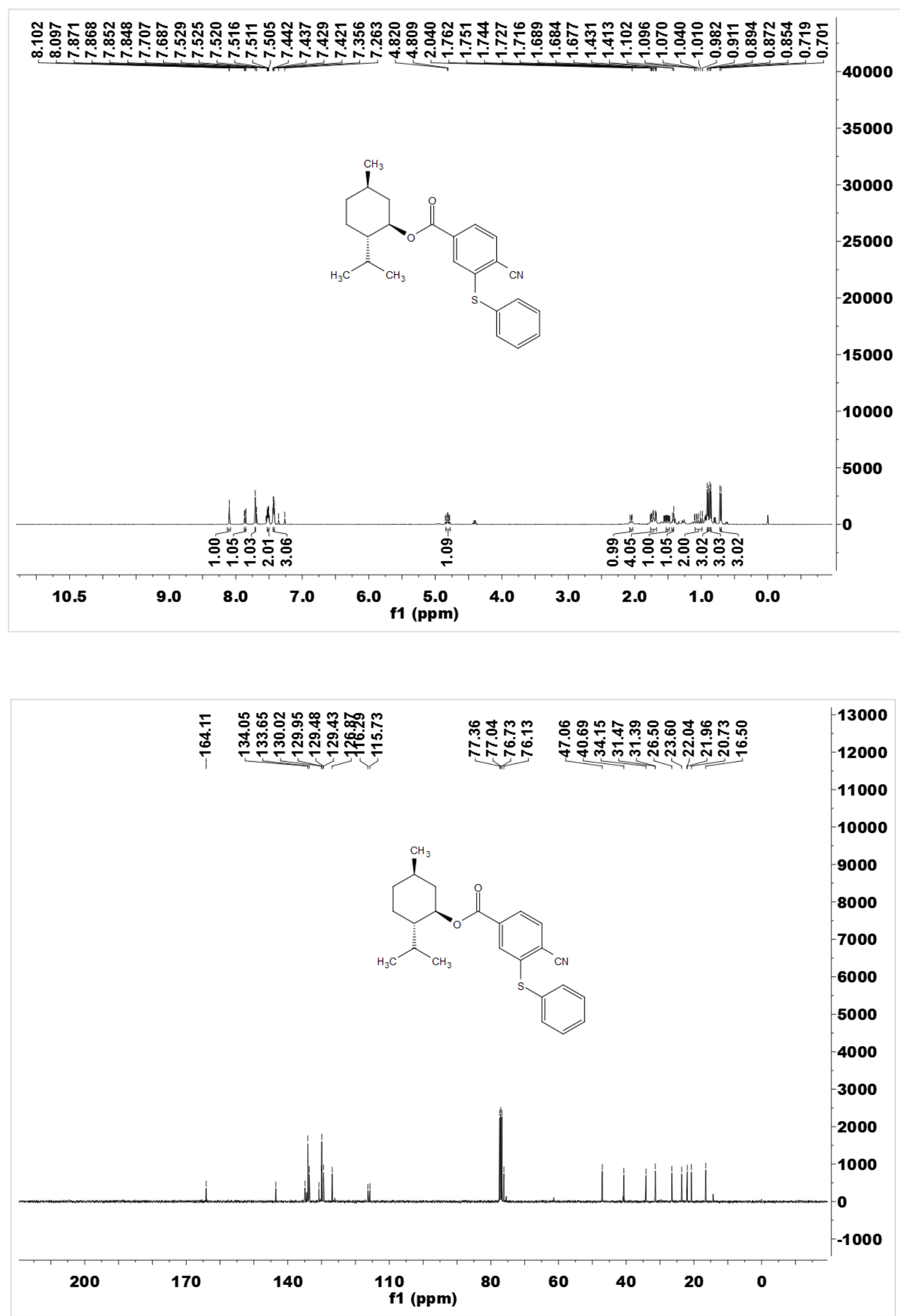

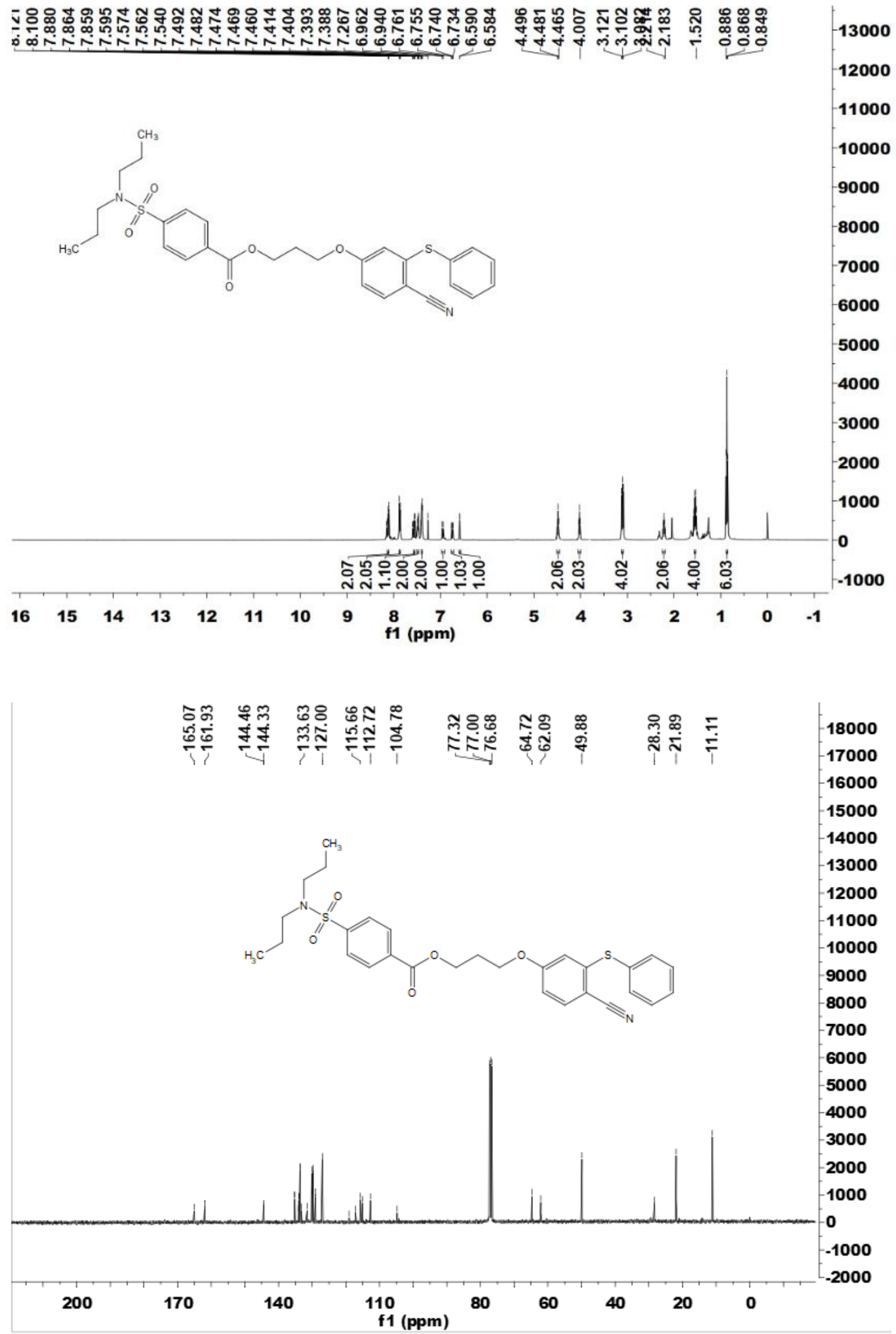

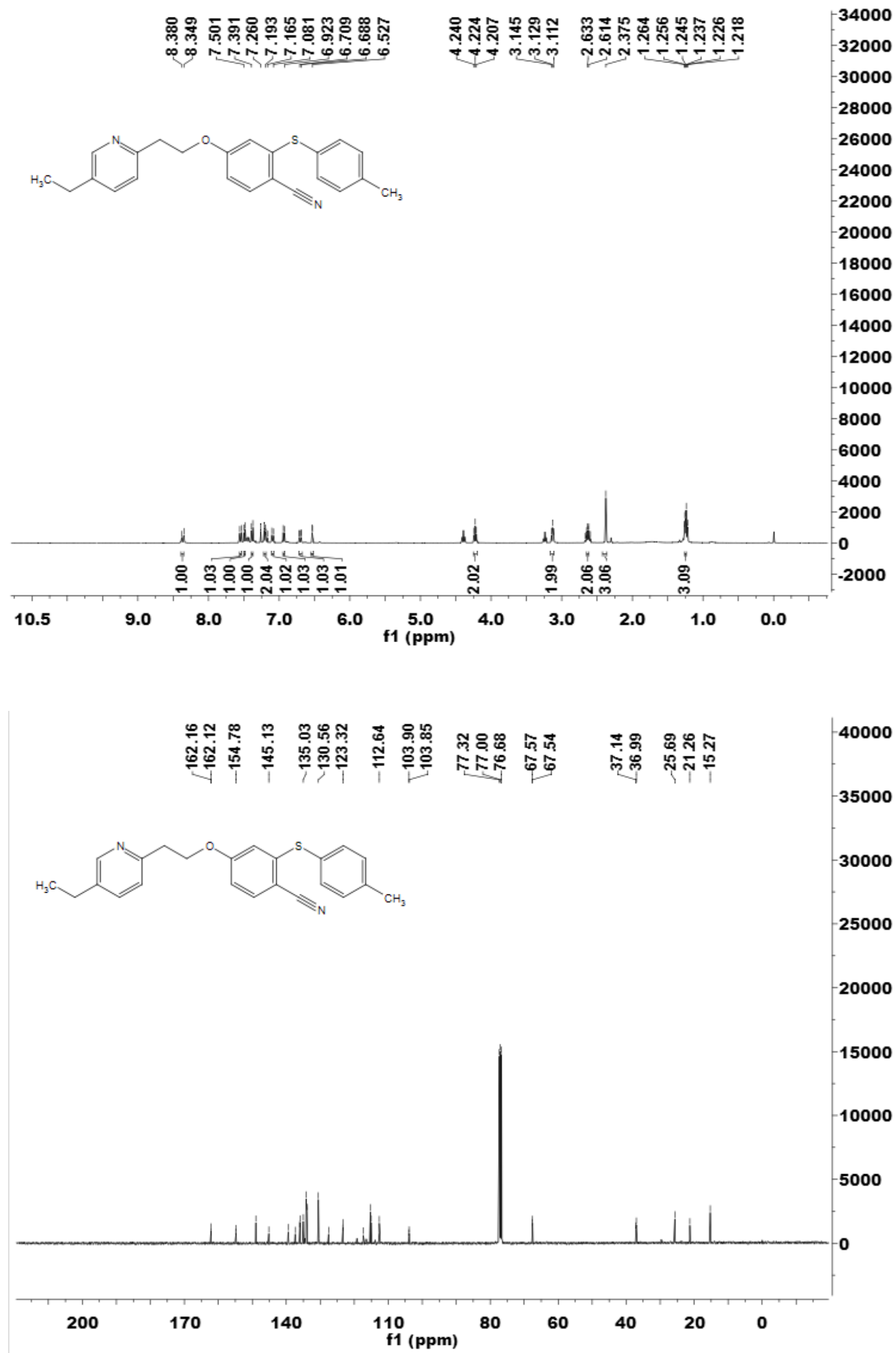
$(8 R, 9 S, 13 S, 14 S)$-13-Methyl-17-oxo-2-(phenylthio)-7,8,9,11,12,13,14,15,16,17-decahydro-6Hcyclopenta[a]phenanthrene-3-carbonitrile (10e)

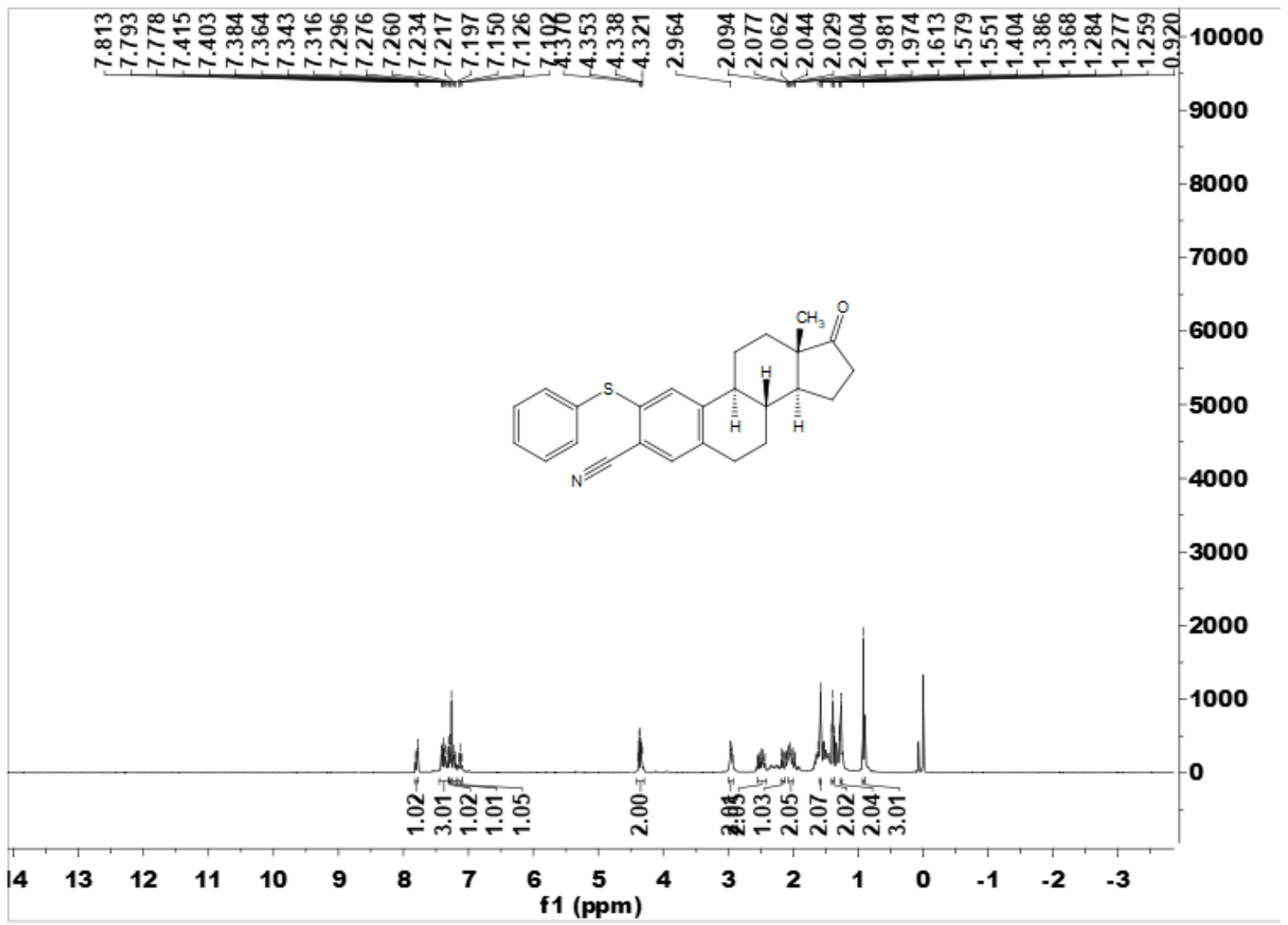

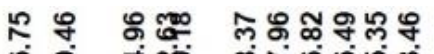

๕.

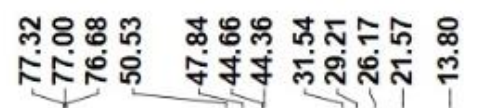

75000

$-70000$

65000

60000

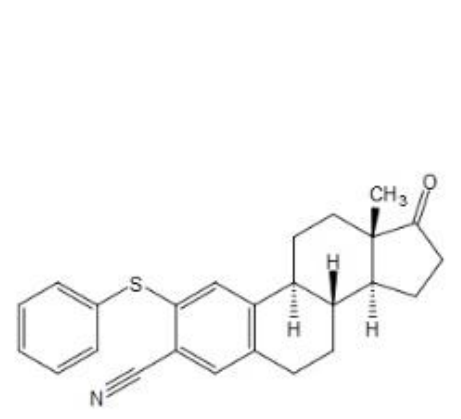

55000

50000

$-45000$

$-40000$

$-35000$

$-30000$

$-25000$

$-20000$

15000

10000

5000

$-0$

$-5000$

200

170

140

110

f1 (ppm)

$\begin{array}{lllll}80 & 60 & 40 & 20 & 0\end{array}$ 

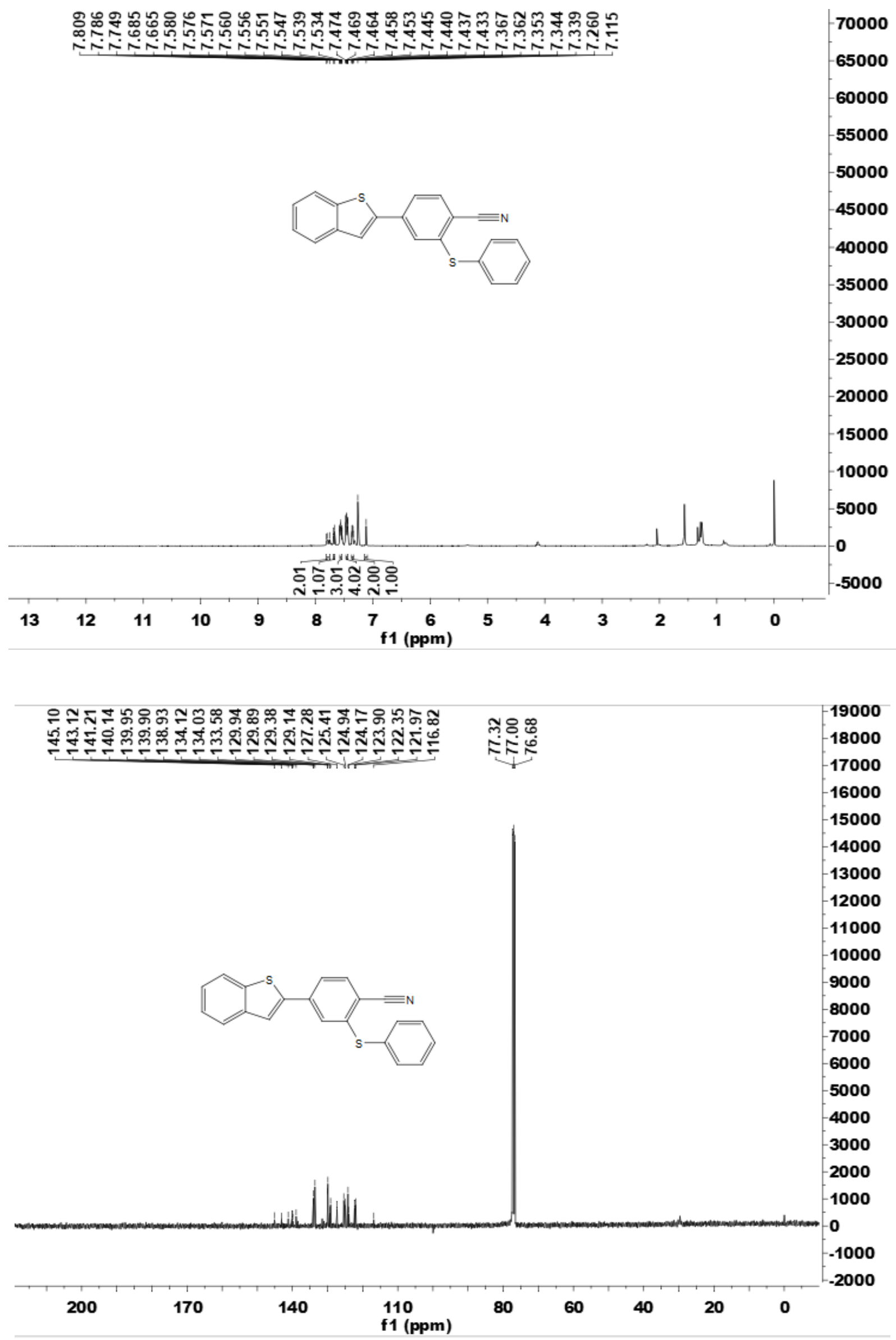
2-(Phenylsulfonyl)benzonitrile (12)
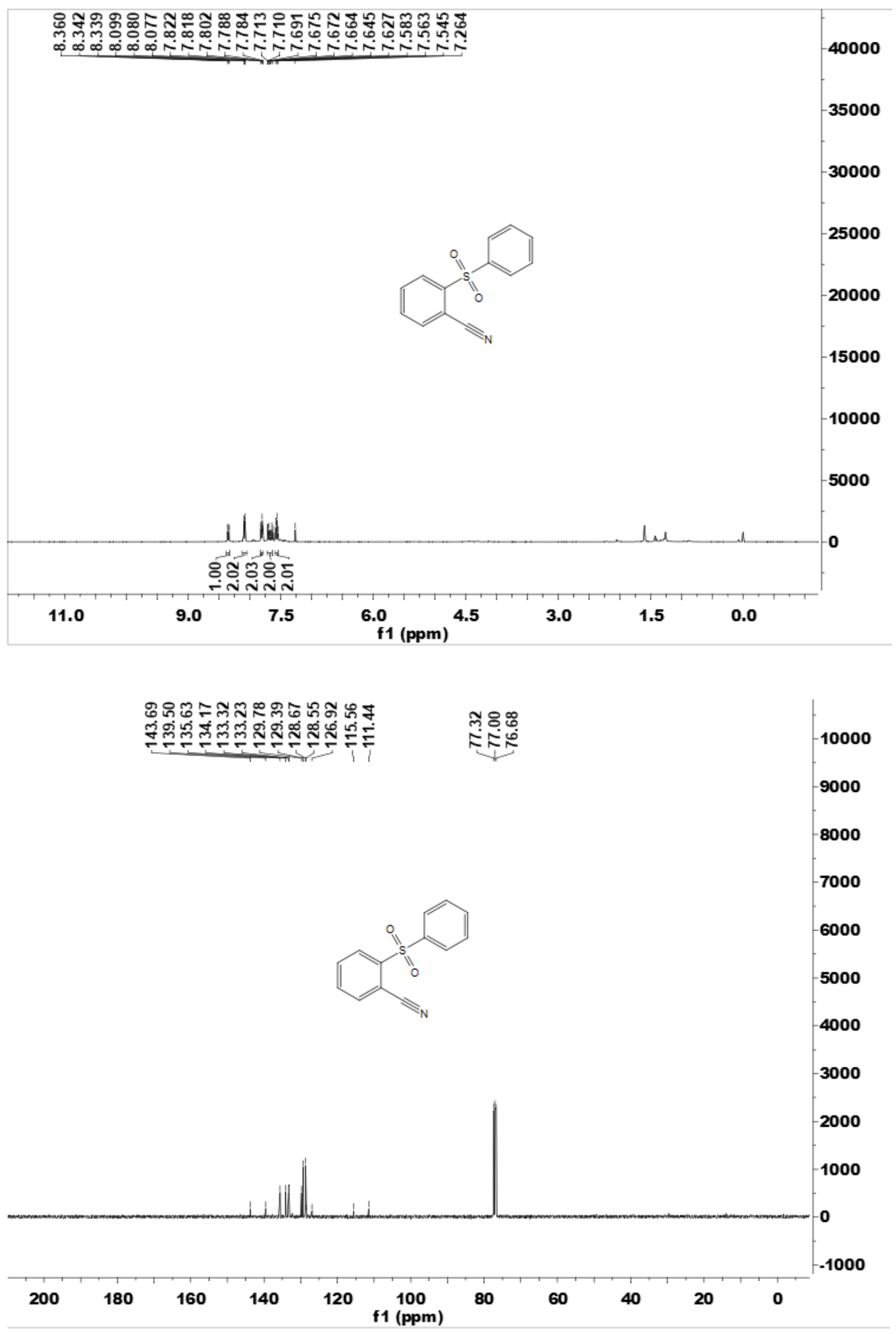
2-(Benzylthio)benzoic acid (13)
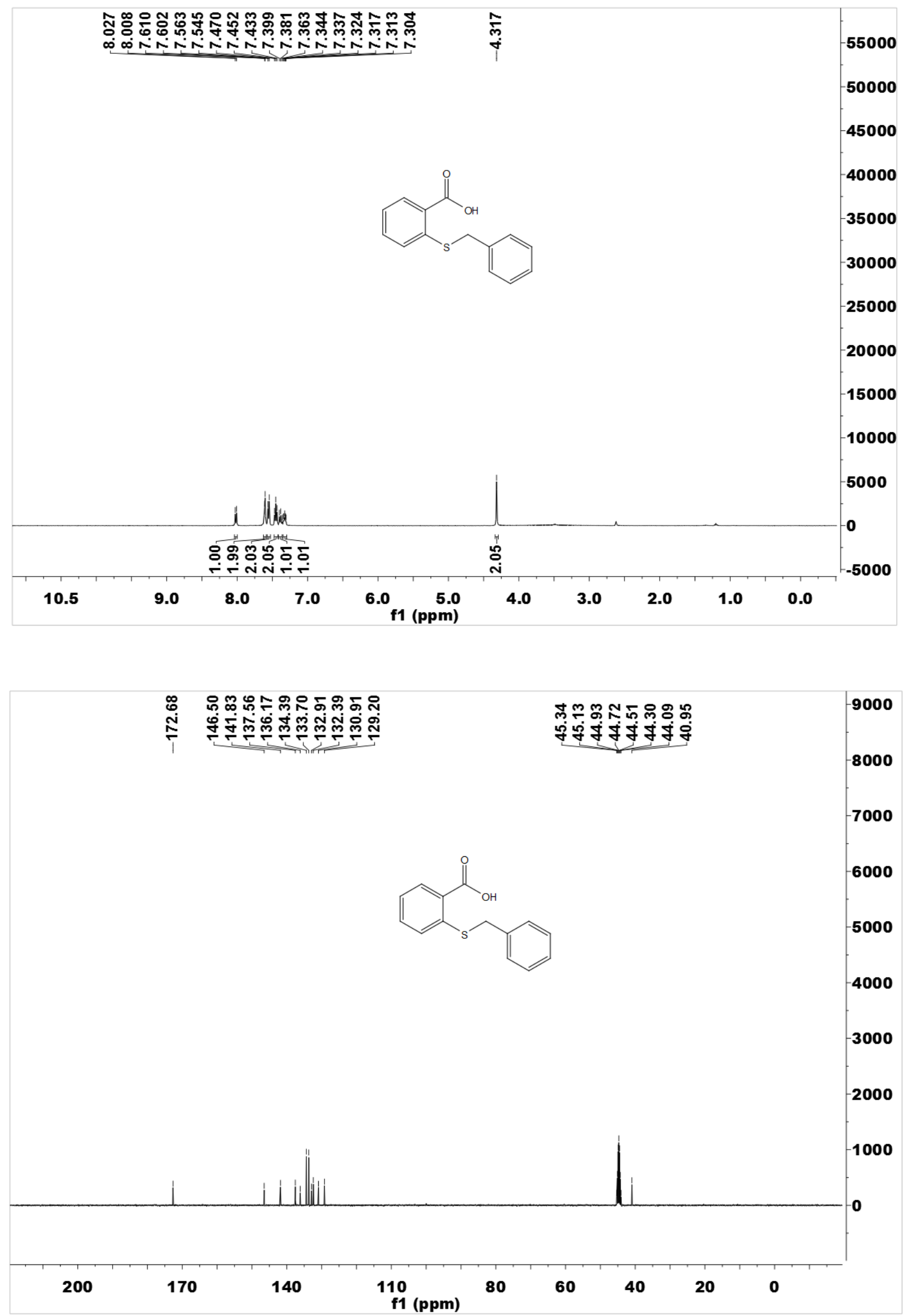
(2-(Phenylthio)phenyl)methanamine (14)
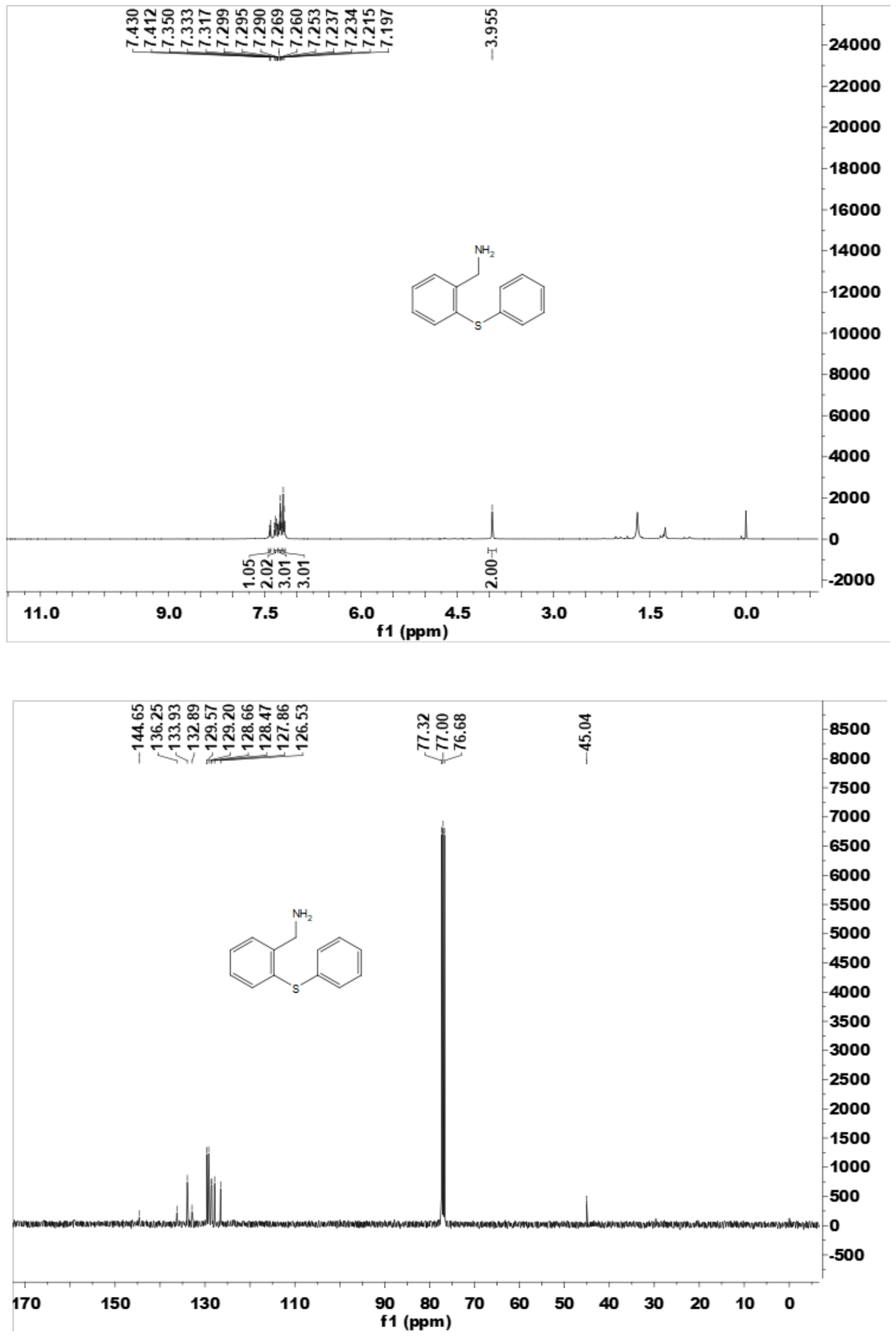
Dibenzo[b,d]thiophene-4-carbonitrile (15)
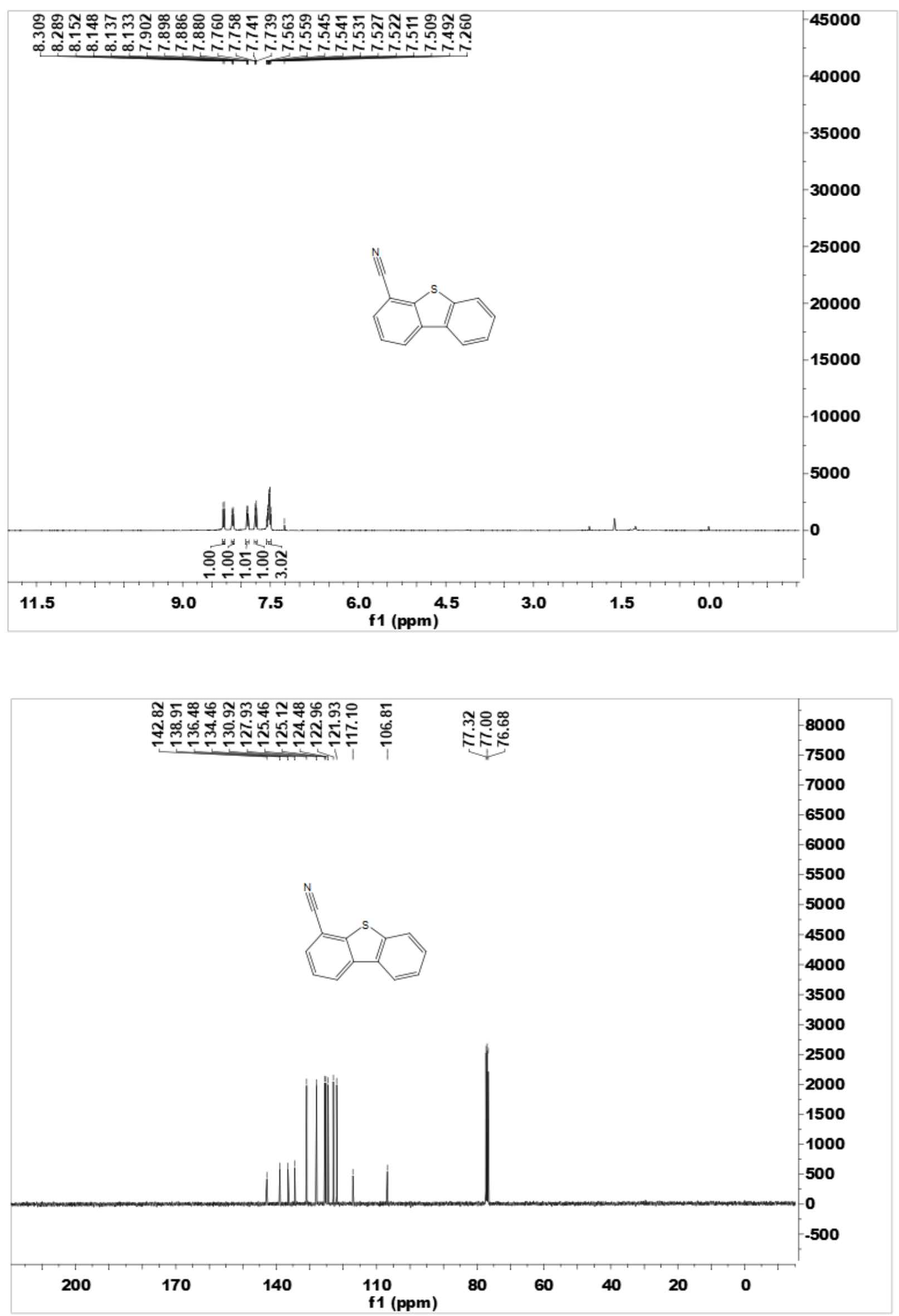
Ethyl 2-((3-aminophenyl)thio)benzimidate (16)
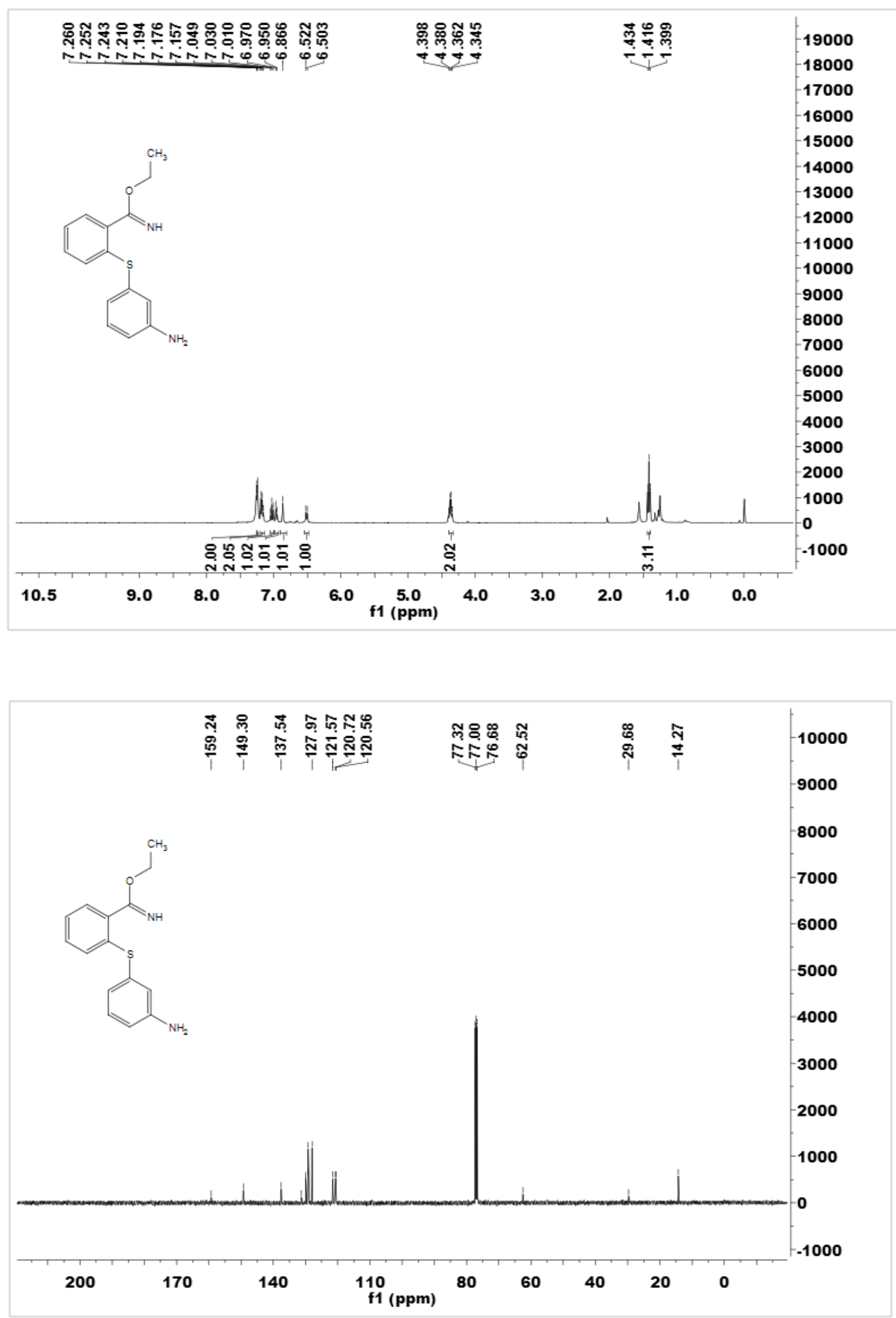
2-((2-(Hydroxymethyl)phenyl)thio)benzonitrile (17)
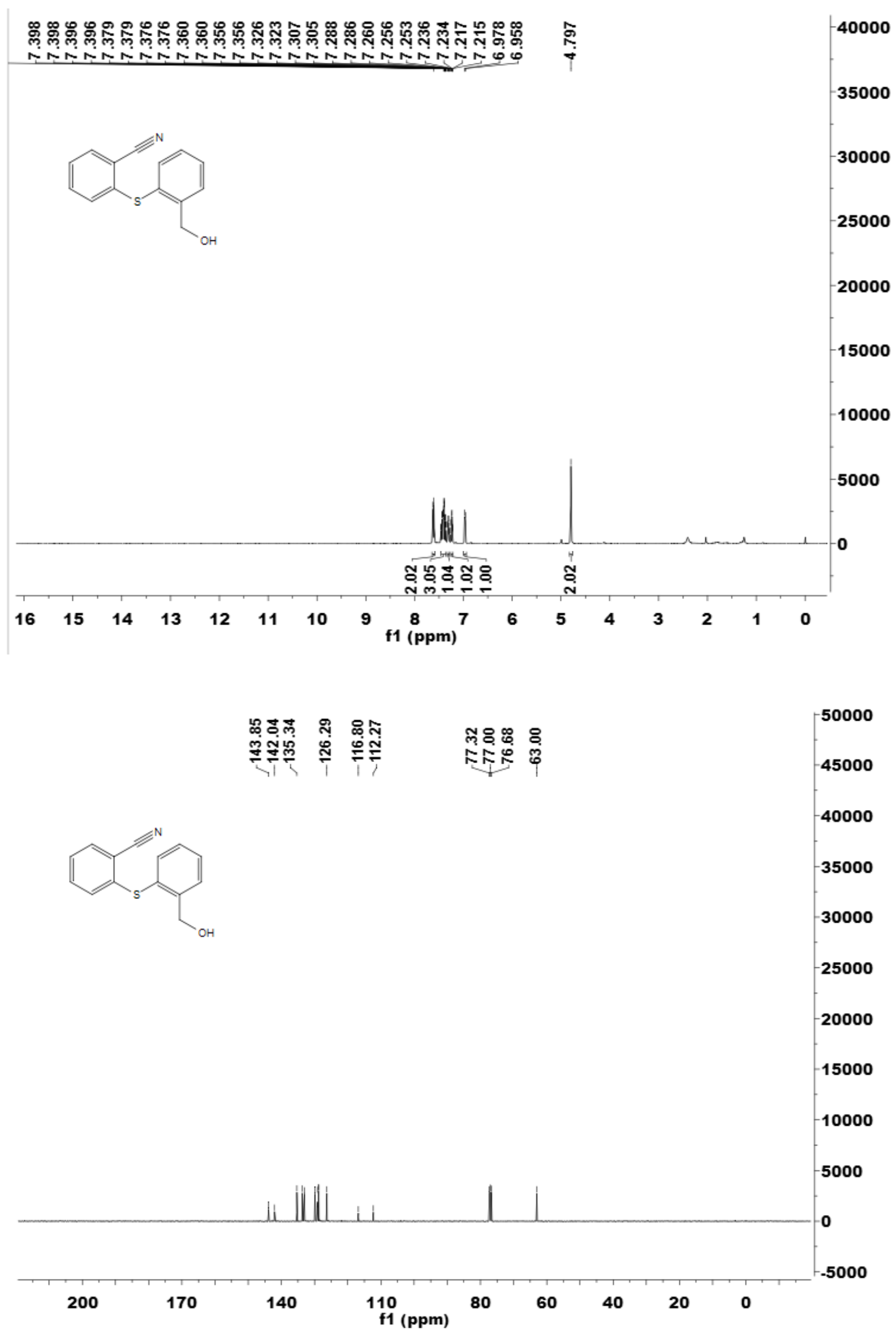
(2-((2-(Aminomethyl)phenyl)thio)phenyl)methanol (18)

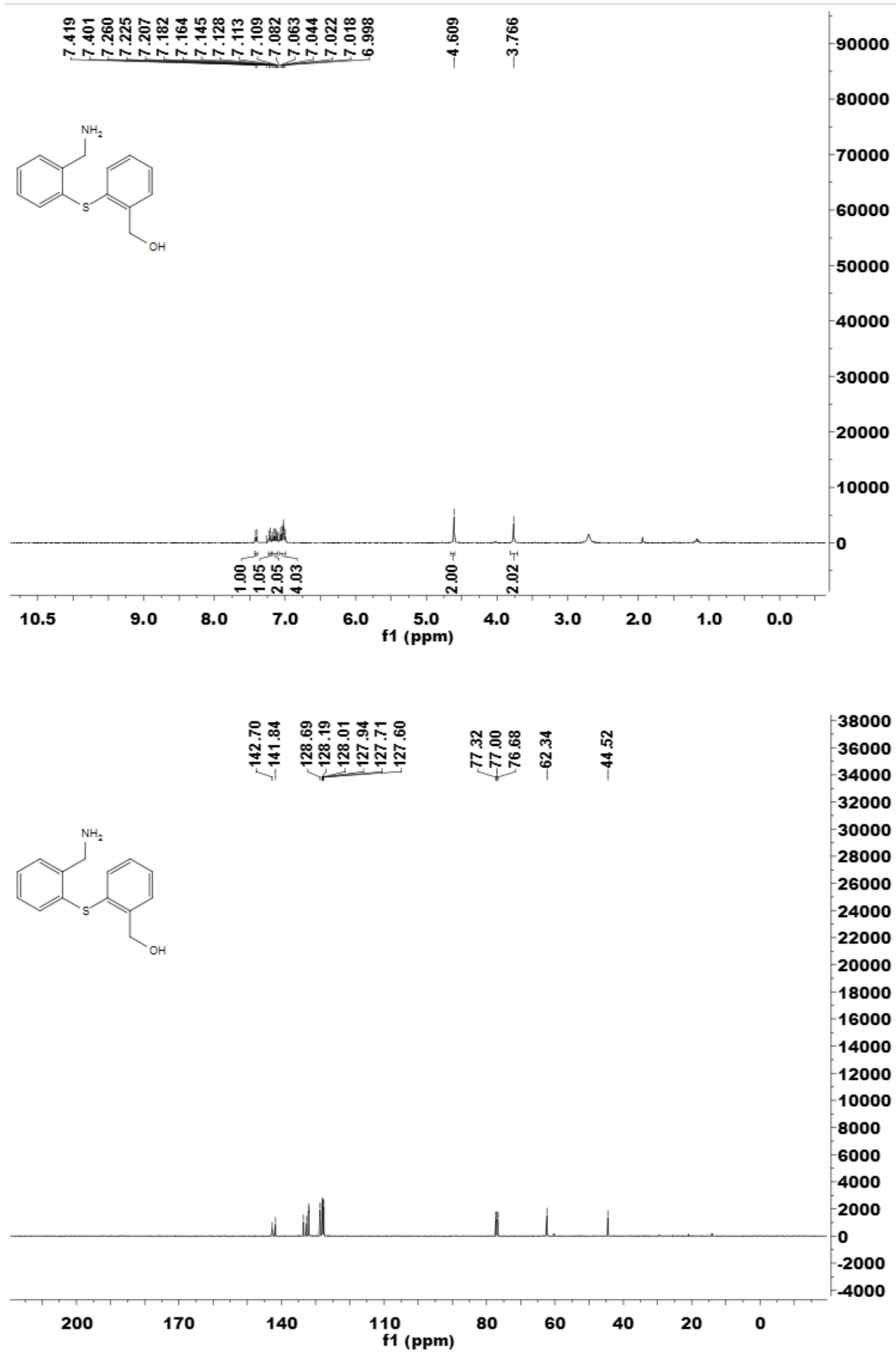

